Morbidity and disability among workers 18 years and older in the Healthcare and Social Assistance sector, 1997-2007

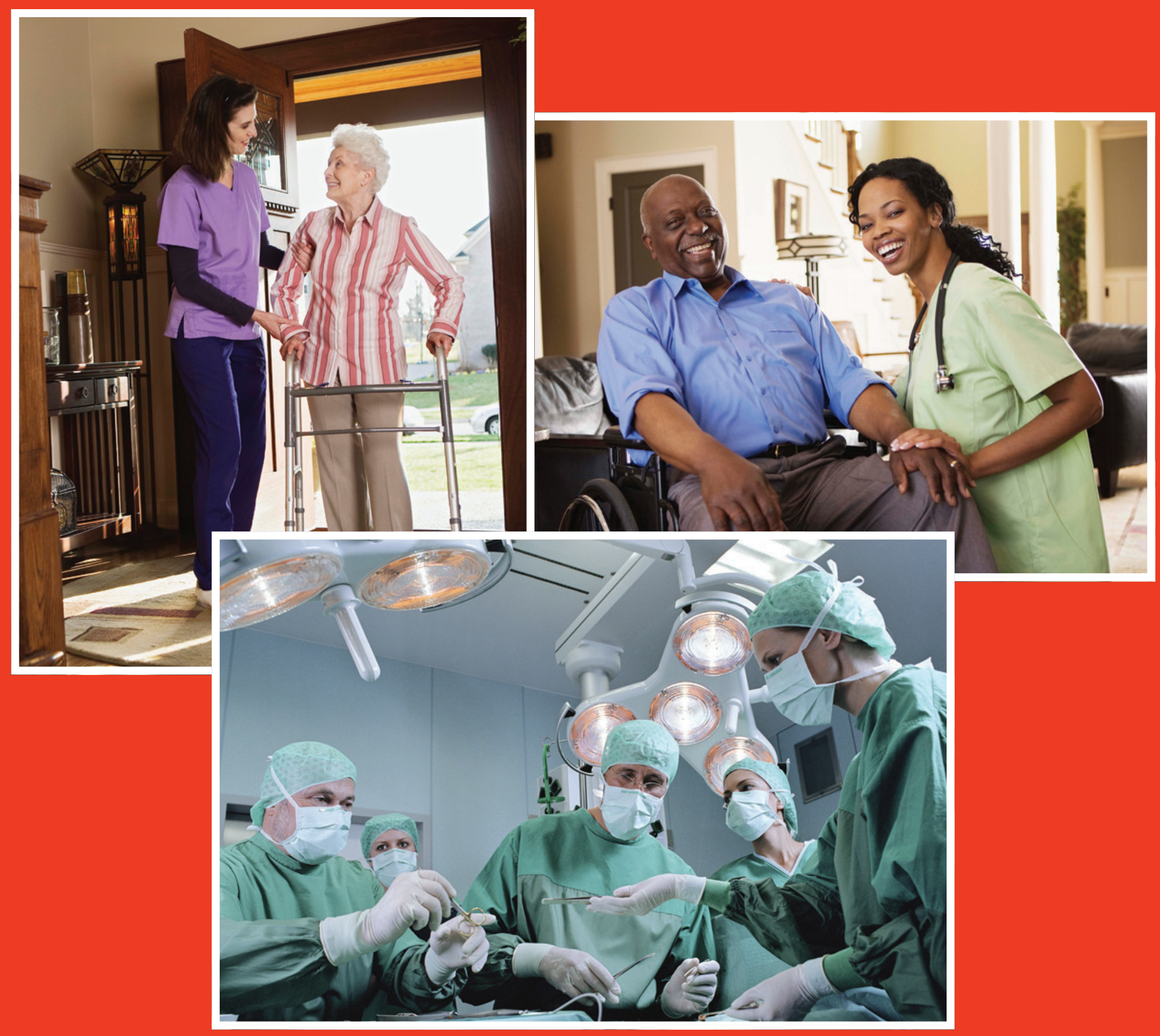

DEPARTMENT OF HEALTH AND HUMAN SERVICES Centers for Disease Control and Prevention National Institute for Occupational Safety and Health
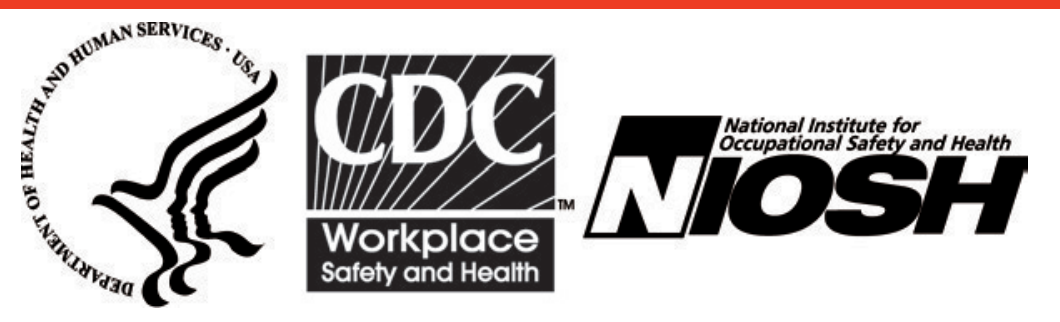


\section{Morbidity and disability among workers 18 years and older in the Healthcare and Social Assistance sector, 1997-2007}

David J. Lee ${ }^{1}$ Ph.D., Evelyn P. Davila' Ph.D., William G. LeBlanc ${ }^{1}$ Ph.D., Alberto J Caban-Martinez ${ }^{1}$ D.O., Ph.D., Lora E Fleming ${ }^{1}$ M.D., Ph.D., Sharon Christ ${ }^{1}$ M.S., Kathryn McCollister ${ }^{1}$ Ph.D., Kris Arheart ${ }^{1}$ Ph.D., John P. Sestito² J.D., M.S.

'University of Miami, Miller School of Medicine, Miami, Florida, USA,

${ }^{2} \mathrm{NIOSH}$ Division of Surveillance, Health Evaluations and Field Studies, Cincinnati, Ohio, USA

DEPARTMENT OF HEALTH AND HUMAN SERVICES

Centers for Disease Control and Prevention

National Institute for Occupational Safety and Health 


\section{This document is in the public domain and may be freely copied or reprinted.}

\section{Disclaimer}

The contents of this report are based on deliverables received from the University of Miami (Contract No. 211-2008-26814) except for editorial and format changes. The findings, and conclusions expressed herein should not be construed to represent any agency determination or policy. Mention of any company or product does not constitute endorsement by the National Institute for Occupational Safety and Health (NIOSH). Citations or links to Web sites external to NIOSH do not constitute NIOSH endorsement of the sponsoring organizations of their program or products. NIOSH is not responsible for the content of these Web sites.

\section{Ordering Information}

To receive documents or other information about occupational safety and health topics, contact NIOSH

Telephone: 1-800-CDC-INFO (1-800-232-4636)

TTY: 1-888-232-6348

email: cdcinfo@cdc.gov

or visit the NIOSH website http://www.cdc.gov/niosh/

For a monthly update on news at NIOSH, subscribe to NIOSH eNEWs by visiting http://www.cdc.gov/ niosh/eNEWS/.

DHHS (NIOSH) Publication No. 2012-161

October 2012 


\section{Contents}

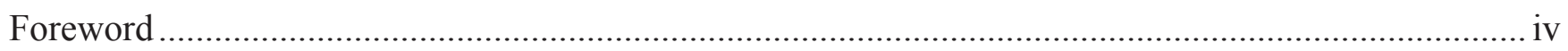

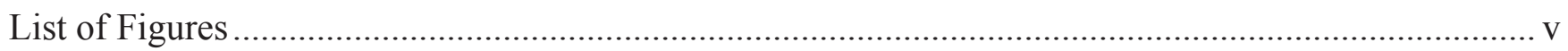

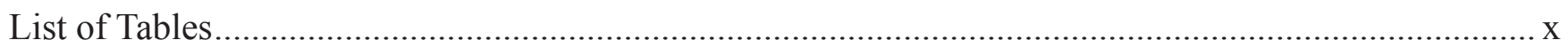

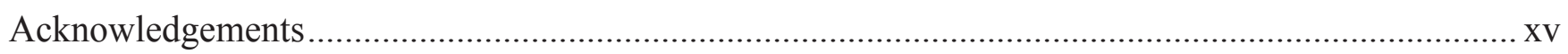

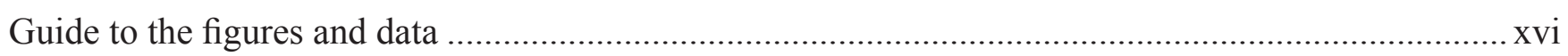

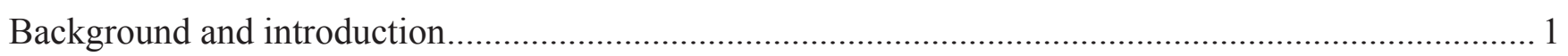

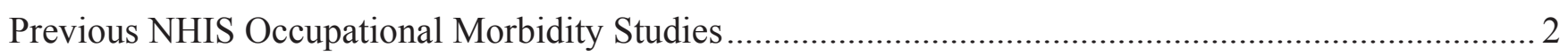

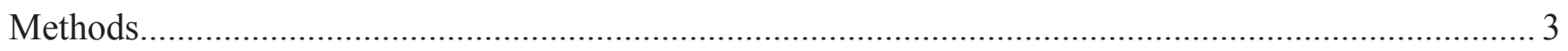

The National Health Interview Survey (NHIS) ............................................................. 3

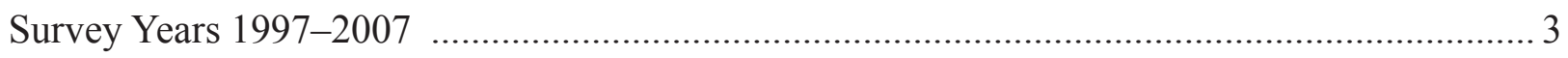

Morbidity and disability prevalence measures ........................................................... 4

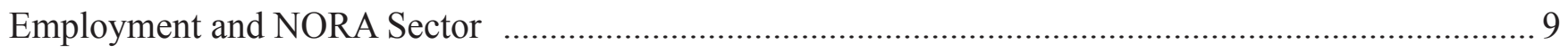

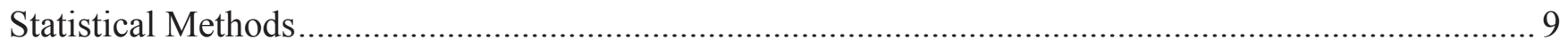

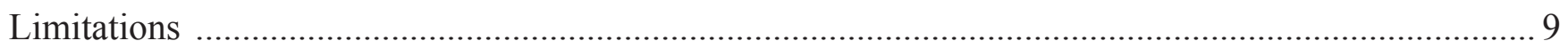

Summary of Estimates for the Workers in the Healthcare and Social Assistance sector..................... 10

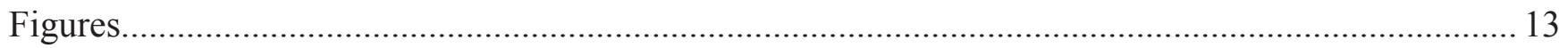

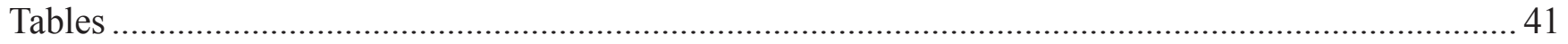

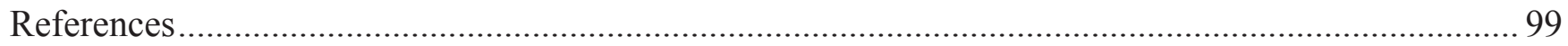

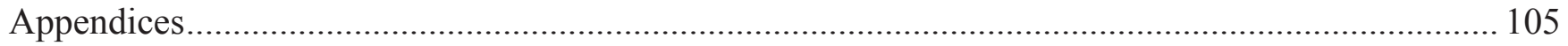

1. Detailed Matrix of Morbidity and Disability Questions from the NHIS asked

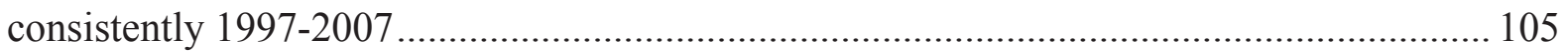

2. Description of Conversion of 1986-2004 National Health Interview Survey (NHIS) Industries into NORA Sectors

3. Conversion of 1986-2004 National Health Interview Survey

(NHIS) Industries into NORA Sectors (flowchart)..... 


\section{Foreword}

The National Institute for Occupational Safety and Health (NIOSH) is the Federal agency responsible for occupational safety and health research. In collaboration with its many partners, NIOSH is committed to the collection, analysis, dissemination, and use of data describing the prevalence of disease and health risk factors among workers in the United States. The National Academies has urged greater use of injury and illness data at the national level to identify priorities, focus resources, and evaluate prevention program effectiveness.

The Occupational Research Group at the University of Miami is illustrative of an extramural partnership which complements NIOSH intramural programs of surveillance and research. Using population health data collected through the Centers for Disease Control and Prevention's (CDC) National Center for Health Statistics (NCHS), they have successfully undertaken a broadly based research program that describes employed worker's disability, disease, health care access, health behaviors and mortality among occupational groups and industry sectors. With the second decade of NORA, NIOSH is developing strategies and programs to better move research to practice within workplaces, using an industry sector-based approach to define high priority needs. The Occupational Research Group at the University of Miami has since completed extensive analyses describing the prevalence of disability, morbidity, mortality, and injury \& disease burden among workers employed within the eight NORA sector groups identified in 2006: Agriculture, forestry and Fishing; Mining; Construction; Manufacturing; Wholesale and Retail Trade; Transportation, Warehousing, and Utilities; Services; and Healthcare and Social Assistance.

This report is one of a series of reports developed to describe the prevalence of disability and morbidity among current workers within these eight sectors. Survey data from the years 1997-2007 were used to describe the five aspects of worker's health, including (1) health status, (2) physical activity limitations or disability, (3) prevalent chronic conditions (cancer, hypertension, heart disease, asthma, diabetes, and severe psychological distress); (4) access to and use of health care services; and (5) health risk factors or behaviors. The report was developed as a descriptive resource to supplement ongoing research, and guide occupational health research and research-to-practice activities within industry.

Additionally, the information in this report will facilitate a Total Worker Health ${ }^{\mathrm{TM}}$ approach to occupational safety and health research. NIOSH increasingly sees the value of integrating occupational safety and health programs that safeguard workers from work-related hazards and programs that promote overall well-being. This report provides data on characteristics of workers health that must be better understood to fulfill the mandate to assure safe and healthful working conditions and to preserve our human resources. I invite you to learn more about the NIOSH Total Worker Health ${ }^{\mathrm{TM}}$ program at http:// www.cdc.gov/niosh/TWH/default.html.

\section{John Howard, M.D.}

Director

National Institute for Occupational Safety and Health

Centers for Disease Control and Prevention 


\section{List of Figures}

\section{Health status among workers in the NORA Healthcare and Social Assistance sector}

Prevalence of a reported decline in health when compared to health status 12 months prior estimated for workers 18 years and older

Figure 1a. Workers 18 years and older by NORA sectors, National Health Interview Survey, 1997-2007

Figure 1b. Workers 18 years and older, Healthcare and Social Assistance sector and All NORA sectors, National Health Interview Survey, 1997-2007

Prevalence of fair or poor self-rated health status estimated for workers 18 years and older

Figure 2a. Workers 18 years and older by NORA sectors, National Health Interview Survey, 1997-2007

Figure 2b. Workers 18 years and older, Healthcare and Social

Assistance sector and All NORA sectors, National Health Interview Survey, 1997-2007.

Mean number of bed disability days during the past 12 months estimated for workers 18 years and older

Figure 3a. Workers 18 years and older by NORA sectors, National Health Interview Survey, 1997-2007

Figure $3 \mathrm{~b}$. Workers 18 years and older, Healthcare and Social

Assistance sector and All NORA sectors, National Health Interview

Survey, 1997-2007

Page 15

Prevalence of having 2 or more bed disability days during the past 12 months estimated for workers 18 years and older

Figure 4a. Workers 18 years and older by NORA sectors, National Health Interview Survey, 1997-2007 Page 16

Figure $4 \mathrm{~b}$. Workers 18 years and older, Healthcare and Social

Assistance sector and All NORA sectors, National Health Interview Survey, 1997-2007

Mean number of work loss days during the past 12 months estimated for workers

18 years and older

Figure 5a. Workers 18 years and older by NORA sectors, National Health Interview Survey, 1997-2007 Page 17

Figure 5b. Workers 18 years and older, Healthcare and Social Assistance sector and All NORA sectors, National Health Interview Survey, 1997-2007 
Prevalence of 6 or more work loss days during the past 12 months estimated for workers 18 years and older

Figure 6a. Workers 18 years and older by NORA sectors, National Health

Interview Survey, 1997-2007 Page 18

Figure 6b. Workers 18 years and older, Healthcare and Social

Assistance sector and All NORA sectors, National Health Interview

Survey, 1997-2007 Page 18

Physical activity limitations among workers in the NORA Healthcare and Social Assistance sector

Prevalence of health problems requiring the use of special equipment estimated for workers 18 years and older

Figure 7a. Workers 18 years and older by NORA sectors, National Health

Interview Survey, 1997-2007 Page 19

Figure $7 \mathrm{~b}$. Workers 18 years and older, Healthcare and Social

Assistance sector and All NORA sectors, National Health Interview

Survey, 1997-2007 Page 19

Prevalence of any functional limitations estimated for workers 18 years and older

Figure 8a. Workers 18 years and older by NORA sectors, National Health Interview Survey, 1997-2007 Page 20

Figure $8 \mathrm{~b}$. Workers 18 years and older, Healthcare sector and All NORA sectors, National Health Interview Survey, 1997-2007...... Page 20

Prevalence of hearing difficulty estimated for workers 18 years and older

Figure 9a. Workers 18 years and older by NORA sectors, National Health Interview Survey, 1997-2007. Page 21

Figure 9b. Workers 18 years and older, Healthcare and Social

Assistance sector and All NORA sectors, National Health Interview

Survey, 1997-2007 Page 21

Prevalence of visual impairment estimated for workers 18 years and older

Figure 10a. Workers 18 years and older by NORA sectors, National Health Interview Survey, 1997-2007. Page 22

Figure 10b. Workers 18 years and older, Healthcare and Social

Assistance sector and All NORA sectors, National Health Interview

Survey, 1997-2007 Page 22

Health and chronic conditions among workers in the NORA Healthcare and Social Assistance sector

Prevalence of cancer estimated for workers 18 years and older

Figure 11a. Workers 18 years and older by NORA sectors, National Health Interview Survey, 1997-2007. Page 23 
Figure 11b. Workers 18 years and older, Healthcare and Social

Assistance sector and All NORA sectors, National Health Interview

Survey, 1997-2007

Page 23

Prevalence of hypertension estimated for workers 18 years and older

Figure 12a. Workers 18 years and older by NORA sectors, National Health

Interview Survey, 1997-2007

Figure 12b. Workers 18 years and older, Healthcare and Social

Assistance sector and All NORA sectors, National Health Interview

Survey, 1997-2007

Page 24

Prevalence of heart disease estimated for workers 18 years and older

Figure 13a. Workers 18 years and older by NORA sectors, National Health

Interview Survey, 1997-2007

Page 25

Figure 13b.Workers 18 years and older, Healthcare and Social

Assistance sector and All NORA sectors, National Health Interview

Survey, 1997-2007

Page 25

Prevalence of asthma estimated for workers 18 years and older

Figure 14a. Workers 18 years and older by NORA sectors National Health

Interview Survey, 1997-2007. Page 26

Figure 14b. Workers 18 years and older, Healthcare and Social

Assistance sector and All NORA sectors, National Health Interview

Survey, 1997-2007

Page 26

Prevalence of diabetes estimated for workers 18 years and older

Figure 15a. Workers 18 years and older by NORA sectors, National Health

Interview Survey, 1997-2007

Page 27

Figure 15b.Workers 18 years and older, Healthcare and Social

Assistance sector and All NORA sectors, National Health Interview

Survey, 1997-2007

Prevalence of severe psychological distress estimated for workers 18 years and older

Figure 16a. Workers 18 years and older by NORA sectors, National Health Interview Survey, 1997-2007.

Page 28

Figure 16b. Workers 18 years and older, Healthcare and Social

Assistance sector and All NORA sectors, National Health Interview

Survey, 1997-2007

Health care utilization among workers in the NORA Healthcare and Social Assistance sector

Prevalence of not having seen a primary health care provider during the past 12 months estimated for workers 18 years and older

Figure 17a. Workers 18 years and older by NORA sectors, National Health Interview Survey, 1997-2007 
Figure 17b. Workers 18 years and older, Healthcare and Social

Assistance sector and All NORA sectors, National Health Interview

Survey, 1997-2007

Page 29

Prevalence of dentist contact of one year or greater estimated for workers 18 years and older

Figure 18a. Workers 18 years and older by NORA sectors, National Health

Interview Survey, 1997-2007. Page 30

Figure 18b. Workers 18 years and older, Healthcare and Social

Assistance sector and All NORA sectors, National Health Interview

Survey, 1997-2007 Page 30

Prevalence of surgery during the past 12 months estimated for workers 18 years and older

Figure 19a. Workers 18 years and older by NORA sectors, National Health Interview Survey, 1997-2007. Page 31

Figure 19b. Workers 18 years and older, Healthcare and Social

Assistance sector and All NORA sectors, National Health Interview

Survey, 1997-2007 Page 31

Prevalence of hospital emergency room visit during the past 12 months estimated for workers 18 years and older

Figure 20a. Workers 18 years and older by NORA sectors, National Health Interview Survey, 1997-2007. Page 32

Figure 20b. Workers 18 years and older, Healthcare and Social

Assistance sector and All NORA sectors, National Health Interview

Survey, 1997-2007 Page 32

\section{Health risk factors or behaviors among workers in the NORA Healthcare and Social Assistance sector}

Prevalence of current smokers estimated for workers 18 years and older

Figure 21a. Workers 18 years and older by NORA sectors, National Health Interview Survey, 1997-2007

Figure 21b. Workers 18 years and older, Healthcare and Social

Assistance sector and All NORA sectors, National Health Interview

Survey, 1997-2007 Page 33

Prevalence of current alcohol drinkers estimated for workers 18 years and older

Figure 22a. Workers 18 years and older by NORA sectors, National Health Interview Survey, 1997-2007. Page 34

Figure 22b. Workers 18 years and older, Healthcare and Social

Assistance sector and All NORA sectors, National Health Interview

Survey, 1997-2007 Page 34 
Prevalence of obesity estimated for workers 18 years and older

Figure 23a. Workers 18 years and older by NORA sectors, National Health Interview Survey, 1997-2007 Page 35

Figure 23b. Workers 18 years and older, Healthcare and Social

Assistance sector and All NORA sectors, National Health Interview Survey, 1997-2007

Prevalence of not meeting CDC recommended leisure time levels of physical activity estimated for workers 18 years and older

Figure 24a. Workers 18 years and older by NORA sectors, National Health Interview Survey, 1997-2007 Page 36

Figure 24b. Workers 18 years and older, Healthcare and Social

Assistance sector and All NORA sectors, National Health Interview

Survey, 1997-2007 Page 36

Prevalence of lifetime HIV test estimated for workers 18 years and older

Figure 25a. Workers 18 years and older by NORA sectors, National Health Interview Survey, 1997-2007

Figure 25b. Workers 18 years and older, Healthcare and Social

Assistance sector and All NORA sectors, National Health Interview

Survey, 1997-2007 Page 37

Prevalence of not receiving an influenza vaccination during the past 12 months estimated for workers 18 years and older

Figure 26a. Workers 18 years and older by NORA sectors, National Health Interview Survey, 1997-2007 Page 38

Figure 26b. Workers 18 years and older, Healthcare and Social

Assistance sector and All NORA sectors, National Health Interview Survey, 1997-2007 Page 38

Prevalence of never receiving a pneumococcal vaccination estimated for workers 60 years and older

Figure 27a. Workers 60 years and older by NORA sectors, National Health Interview Survey, 1997-2007 Page 39

Figure 27b. Workers 18 years and older, Healthcare and Social Assistance sector and All NORA sectors, National Health Interview Survey, 1997-2007 


\section{List of Tables}

Table 1. Estimated U.S. worker population and sample size for workers 18 years and older, All NORA sectors and Healthcare and Social Assistance sector, National Health Interview Survey, 1997-2007. Page 41

Table 2. U.S. Health Status, Disability and Morbidity Prevalence (percent) estimates for workers 18 years and older, NORA sectors, National Health Interview Survey, 1997-2007 Page 42

\section{Health status among workers in the NORA Healthcare and Social Assistance sector}

Table 3. Prevalence of a reported decline in health when compared to health status 12 months prior estimated for workers 18 years and older, All NORA sectors, National Health Interview Survey, 1997-2007 Page 44

Table 4. Prevalence of a reported decline in health when compared to health status 12 months prior estimated for workers 18 years and older, Healthcare and Social Assistance sector, National Health Interview Survey, 1997-2007. Page 45

Table 5. Prevalence of fair or poor self-rated health status estimated for workers 18 years and older, All NORA sectors, National Health Interview Survey, 1997-2007 Page 46

Table 6. Prevalence of fair or poor self-rated health status estimated for workers 18 years and older, Healthcare and Social Assistance sector, National Health Interview Survey, 1997-2007. Page 47

Table 7. Mean number of bed disability days during the past 12 months estimated for workers 18 years and older, All NORA sectors, National Health Interview Survey, 1997-2007 Page 48

Table 8. Mean number of bed disability days during the past 12 months estimated for workers 18 years and older, Healthcare and Social Assistance sector, National Health Interview Survey, 1997-2007 Page 49

Table 9. Prevalence of having 2 or more bed disability days during the past 12 months estimated for workers 18 years and older, All NORA sectors, National Health Interview Survey, 1997-2007. Page 50

Table 10. Prevalence of having 2 or more bed disability days during the past 12 months estimated for workers 18 years and older, Healthcare and Social Assistance sector, National Health Interview Survey, 1997-2007. Page 51

Table 11. Mean number of work loss days during the past 12 months estimated for workers 18 years and older, All NORA sectors, National Health Interview Survey, 1997-2007..... Page 52

Table 12. Mean number of work loss days during the past 12 months estimated for workers 18 years and older, Healthcare and Social Assistance sector, National Health Interview Survey, 1997-2007. 
Table 13. Prevalence of 6 or more work loss days during the past 12 months estimated for workers 18 years and older, All NORA sectors, National Health Interview Survey, 1997-2007. Page 54

Table 14. Prevalence of 6 or more work loss days during the past 12 months estimated for workers 18 years and older, Healthcare and Social Assistance sector, National Health Interview Survey, 1997-2007 Page 55

Physical activity limitations among workers in the NORA Healthcare and Social Assistance sector

Table 15. Prevalence of health problems requiring the use of special equipment estimated for workers 18 years and older, All NORA sectors, National Health Interview Survey, 1997-2007 Page 56

Table 16. Prevalence of health problems requiring the use of special equipment estimated for workers 18 years and older, Healthcare and Social Assistance sector, National Health Interview Survey, 1997-2007 Page 57

Table 17. Prevalence of any functional limitations estimated for workers 18 years and older, All NORA sectors, National Health Interview Survey, 1997-2007...... Page 58

Table 18. Prevalence of any functional limitations estimated for workers 18 years and older, Healthcare and Social Assistance sector, National Health Interview Survey, 1997-2007. Page 59

Table 19. Prevalence of hearing difficulty estimated for workers 18 years and older, All NORA sectors, National Health Interview Survey, 1997-2007. Page 60

Table 20. Prevalence of hearing difficulty estimated for workers 18 years and older, Healthcare and Social Assistance sector, National Health Interview Survey, 1997-2007 Page 61

Table 21. Prevalence of visual impairment estimated for workers 18 years and older, All NORA sectors, National Health Interview Survey, 1997-2007 Page 62

Table 22. Prevalence of visual impairment estimated for workers 18 years and older, Healthcare and Social Assistance sector, National Health Interview Survey, 1997-2007 Page 63

Health and chronic conditions among workers in the NORA Healthcare and Social Assistance sector

Table 23. Prevalence of cancer estimated for workers 18 years and older, All NORA sectors, National Health Interview Survey, 1997-2007 Page 64

Table 24. Prevalence of cancer estimated for workers 18 years and older, Healthcare and Social Assistance sector, National Health Interview Survey, 1997-2007. Page 65 
Table 25. Prevalence of hypertension estimated for workers 18 years and older, All NORA sectors, National Health Interview Survey,

1997-2007. Page 66

Table 26. Prevalence of hypertension estimated for workers 18 years and older, Healthcare and Social Assistance sector, National Health Interview Survey, 1997-2007. Page 67

Table 27. Prevalence of heart disease estimated for workers 18 years and older, All NORA sectors, National Health Interview Survey, 1997-2007 Page 68

Table 28. Prevalence of heart disease estimated for workers 18 years and older, Healthcare and Social Assistance sector, National Health Interview Survey, 1997-2007. Page 69

Table 29. Prevalence of asthma estimated for workers 18 years and older, All

NORA sectors, National Health Interview Survey, 1997-2007 Page 70

Table 30. Prevalence of asthma estimated for workers 18 years and older, Healthcare and Social Assistance sector, National Health Interview Survey, 1997-2007. Page 71

Table 31. Prevalence of diabetes estimated for workers 18 years and older, All NORA sectors, National Health Interview Survey, 1997-2007 Page 72

Table 32. Prevalence of diabetes estimated for workers 18 years and older, Healthcare and Social Assistance sector, National Health Interview Survey, 1997-2007. Page 73

Table 33. Prevalence of severe psychological distress estimated for workers 18 years and older, All NORA sectors, National Health Interview Survey, 1997-2007. Page 74

Table 34. Prevalence of severe psychological distress estimated for workers 18 years and older, Healthcare and Social Assistance sector, National Health Interview Survey, 1997-2007 Page 75

Health care utilization among workers in the NORA Healthcare and Social Assistance sector

Table 35. Prevalence of not having seen a primary health care provider during the past 12 months estimated for workers 18 years and older, All NORA sectors, National Health Interview Survey, 1997-2007

Page 76

Table 36. Prevalence of not having seen a primary health care provider during the past 12 months estimated for workers 18 years and older, Healthcare and Social Assistance sector,National Health Interview Survey, 1997-2007 Page 77

Table 37. Prevalence of no dentist contact during the past year estimated for workers 18 years and older, All NORA sectors, National Health Interview Survey, 1997-2007. 
Table 38. Prevalence of no dentist contact during the past year estimated for workers 18 years and older, Healthcare and Social Assistance sector, National Health Interview Survey, 1997-2007. Page 79

Table 39. Prevalence of surgery during the past 12 months estimated for workers 18 years and older, All NORA sectors, National Health Interview Survey, 1997-2007 Page 80

Table 40. Prevalence of surgery during the past 12 months estimated for workers 18 years and older, Healthcare and Social Assistance sector, National Health Interview Survey, 1997-2007 Page 81

Table 41. Prevalence of hospital emergency room visit during the past 12 months estimated for workers 18 years and older, All NORA sectors, National Health Interview Survey, 1997-2007. Page 82

Table 42. Prevalence of hospital emergency room visit during the past 12 months estimated for workers 18 years and older, Healthcare and Social Assistance sector, National Health Interview Survey, 1997-2007. Page 83

Health risk factors or behaviors among workers in the NORA Healthcare and Social Assistance sector

Table 43. Prevalence of current smokers estimated for workers 18 years and older, All NORA sectors, National Health Interview Survey, 1997-2007..... Page 84

Table 44. Prevalence of current smokers estimated for workers 18 years and older, Healthcare and Social Assistance sector, National Health Interview Survey, 1997-2007. Page 85

Table 45. Prevalence of current alcohol drinkers estimated for workers 18 years and older, All NORA sectors, National Health Interview Survey, 1997-2007 Page 86

Table 46. Prevalence of current alcohol drinkers estimated for workers 18 years and older, Healthcare and Social Assistance sector, National Health Interview Survey, 1997-2007. Page 87

Table 47. Prevalence of obesity estimated for workers 18 years and older, All NORA sectors, National Health Interview Survey, 1997-2007 Page 88

Table 48. Prevalence of obesity estimated for workers 18 years and older, Healthcare and Social Assistance sector, National Health Interview Survey, 1997-2007 Page 89

Table 49. Prevalence of not meeting CDC recommended leisure time levels of physical activity estimated for workers 18 years and older, All NORA sectors, National Health Interview Survey, 1997-2007. Page 90 
Table 50. Prevalence of not meeting CDC recommended leisure time levels of physical activity estimated for workers 18 years and older, Healthcare and Social Assistance sector, National Health Interview Survey, 1997-2007. Page 91

Table 51. Prevalence of lifetime HIV test estimated for workers 18 years and older, All NORA sectors, National Health Interview Survey, 1997-2007. Page 92

Table 52. Prevalence of lifetime HIV test estimated for workers 18 years and older, Healthcare and Social Assistance sector, National Health Interview Survey, 1997-2007 Page 93

Table 53. Prevalence of not receiving an influenza vaccination during the past 12 months estimated for workers 18 years and older, All NORA sectors, National Health Interview Survey, 1997-2007 Page 94

Table 54. Prevalence of not receiving an influenza vaccination during the past 12 months estimated for workers 18 years and older, Healthcare and Social Assistance sector, National Health Interview Survey, 1997-2007. Page 95

Table 55. Prevalence of never receiving a pneumococcal vaccination estimated for workers 60 years and older, All NORA sectors, National Health Interview Survey, 1997-2007 Page 96

Table 56. Prevalence of never receiving a pneumococcal vaccination estimated for workers 60 years and older, Healthcare and Social Assistance sector, National Health Interview Survey, 1997-2007 


\section{Acknowledgements}

This document is one of eight documents prepared by NIOSH, each based on the March, 2010 report NORA Morbidity and Disability: The National Health Interview Survey (NHIS) 1997-2007 prepared under contract with the Department of Epidemiology and Public Health, University of Miami School of Medicine. NIOSH has supplemented the original report with additional figures, and reformatted the contents to conform to NIOSH publication guidelines.

The contract report and each of NIOSH documents received technical reviews. We extend our thanks to the reviewers for their thoughtful and insightful comments. We acknowledge the contributions of: John Mendeloff, Ph.D., RAND Center for Health and Safety in the Workplace; Eve Powell-Griner, Ph.D., Division of Health Interview Statistics, National Center for Health Statistics; Gordon Smith, M.D., Department of Epidemiology and Preventive Medicine, University of Maryland School of Medicine; Doug Trout, M.D., M.H.S., K. Ann Berry, Ph.D., MBA., Roger R. Rosa, Ph.D., Tanya Headley, M.S., David Utterback, Ph.D., James Helmkamp, Ph.D., Linda McWilliams, M.S., Casey Chosewood, M.D., and Anita Schill, Ph.D., National Institute for Occupational Safety and Health.

The report is composed of text, color figures, and tables. Color choices were influenced by the work of Cynthia A. Brewer, Pennsylvania State University, based on colors from ColorBrewer.org. Color image templates were created and evaluated using http://www.visicheck.com, a visual simulation tools for color blindness.

\section{Editorial and Production Support}

\section{Editor}

John P. Sestito, J.D., M.S.

\section{Graphics Development and Editing}

John P. Sestito, J.D., M.S.

Evelyn Davila, Ph.D.

\section{Document Design and Desktop Publishing}

Greg Hartle, General Infomatics (CTR) 


\section{Guide to the figures and data}

Data are presented on pages 13-39 using two horizontal bar charts to summarize NHIS estimates for 27 morbidity and disability measures. The first bar chartlfigure presents overall summary estimates for All NORA Sectors (i.e., all workers) and workers employed within each of the eight NORA sectors.

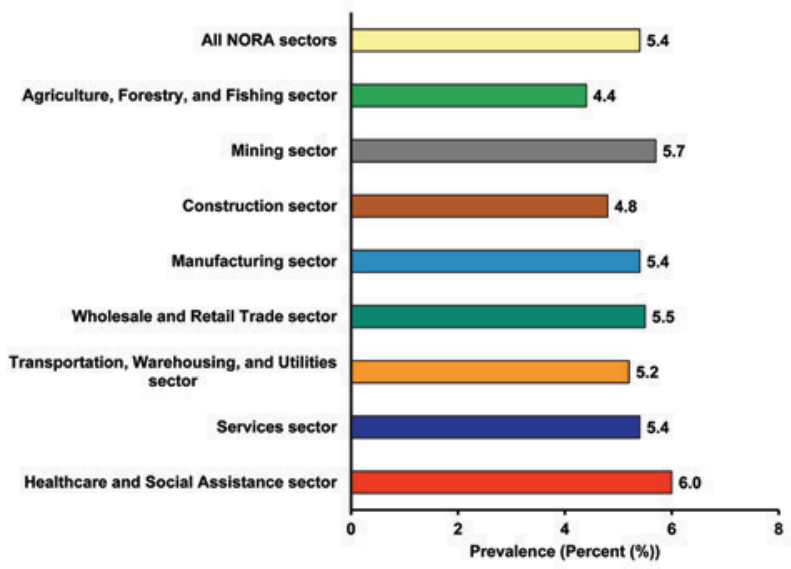

The horizontal bar for Healthcare and Social Assistance is assigned a different color to contrast with other entries.

Healthcare and

Social Assistance

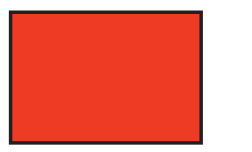

All NORA

Sectors

The second bar chartlfigure presents estimates by population subgroups (all subgroups, gender, race, ethnicity, age, education and insurance status) for the Healthcare and Social Assistance sector and the All NORA sectors category.

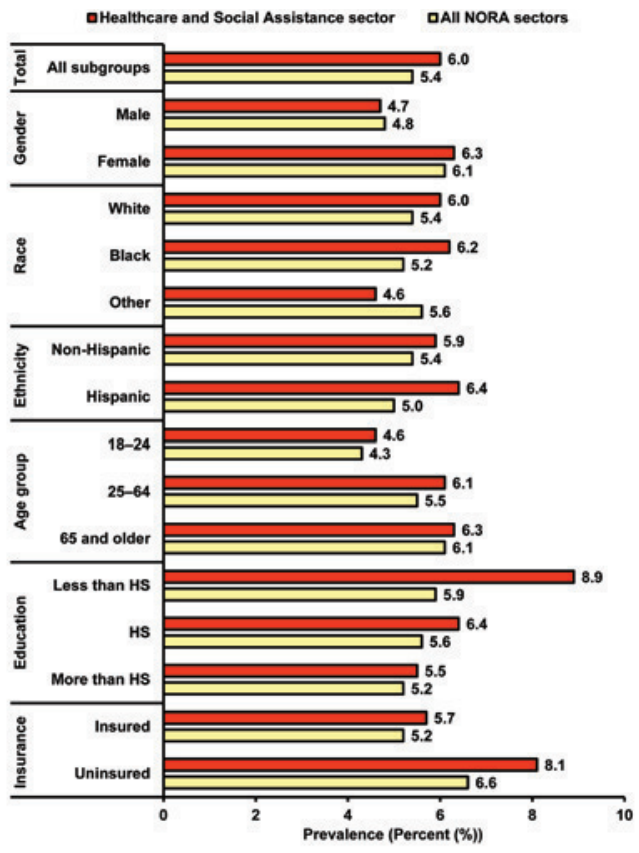

The horizontal bar for Healthcare and Social Assistance is assigned a different color to contrast with All NORA Sectors.

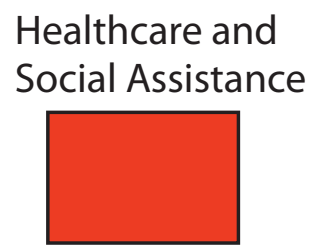

All NORA

Sectors

The majority of the figures present prevalence (percentage) values reflecting non-zero estimates. For a small number of figures, the response values displayed may include symbols indicating (1) no data available, which occurs where the population subgroup sample is zero; (2) the computed quantity or value is greater than 0.0 but less than $0.05 \%$ (symbol (0.0)); and (3) there were no cases in that particular cell, and thus the response value estimated (symbol (-)) as zero quantity. These values are distinguished in the figures with the following symbols:

(---) No data available indicating the population subgroup sample is zero

(0.0) The estimated prevalence value is greater than 0.0 but less than $0.05 \%$

(-) No cases in this cell, thus the response value is estimated as zero quantity 


\section{Background and introduction}

The ongoing collection, analysis, dissemination and use of population health data has been an integral part of the National Institute for Occupational Safety and Health (NIOSH) research program since the 1970s. In collaboration with its many partners, NIOSH has established programs to describe the magnitude of occupational hazards, diseases, and injuries in the United States. These activities document the nation's progress in reducing the burden of work-related diseases and injuries. These activities have continually identified new areas that require additional research and prevention efforts. Despite these accomplishments, occupational health surveillance in the United States remains fragmented, with substantial data gaps.

NIOSH conducts a range of efforts in the area of research, guidance, information, and service. To better coordinate these efforts, NIOSH has adopted aspects of matrix management to both organize and manage its research portfolio. In 2005 NIOSH solicited the involvement of both intramural staff, and extramural partners and stakeholders, to develop the National Occupational Research Agenda (NORA) goals to advance the prevention of occupational injuries and illnesses for eight targeted sectors of U.S. industry. The eight sector programs, with their corresponding North American Industry Classification System (NAICS) 2-digit codes, are identified below:

\begin{tabular}{|l|l|}
\hline NORA sectors & NAICS codes \\
\hline Agriculture, Forestry, and Fishing & 11 \\
\hline Mining & 21 \\
\hline Construction & 23 \\
\hline Manufacturing & $31-33$ \\
\hline Wholesale and Retail Trade & $42,44-45$, \\
\hline Transportation, Warehousing, and Utilities & $48-49,22$ \\
\hline Healthcare and Social Assistance & $62 ; 54194$ \\
\hline Services & $51-56,61,71-72,81,92$ \\
\hline
\end{tabular}

As an integral part of the NIOSH Program Portfolio, the NIOSH Surveillance program has developed five strategic goals. These goals outline the major elements of a long-range plan for a comprehensive occupational surveillance program. These national goals seek to both strengthen and balance national and state-based partnerships, and support a comprehensive intramural program of illness, injury, and hazard surveillance activities.

Occupational health surveillance is challenged to narrow many substantial data and information gaps. To this end, the NIOSH surveillance program promotes increased coordination and information exchange within NIOSH and among our many external partner organizations. One such organization is the Occupational Research Group at the University of Miami. This Group was funded in the past by NIOSH to study the U.S. employed population's morbidity and mortality using statistical resources publicly available through the National Center for Health Statistics (NCHS) of the Centers for Disease Control and Prevention (CDC).

The focus of this report is to describe the prevalence of morbidity and disability among employed workers in the Healthcare and Social Assistance sector. This report is based on work products from comprehensive analyses performed by the Occupational Research Group at the University of Miami using an established methodology to assess predictors of acute and chronic disability morbidity for U.S. workers by the National Occupational Research Agenda (NORA) sectors using the 1997-2007 National Health Interview Survey (NHIS) data [Fleming et al. 2004; Fleming et al. 2005; Fleming et al. 2007a]. 
The National Health Interview Survey (NHIS) is a continuous multipurpose and multistage probability area in-person survey of the U.S. civilian non-institutionalized population living at addressed dwellings [NCHS 2000]. Each week a probability sample of households is interviewed by trained personnel to obtain information about the characteristics of each member of the household. Data from the NHIS include a range of measures of population health, acute and chronic disability, health care access, and individual risk factor and health behavior collected for all participants. After adjustment for sample weights and design effects, prevalence measures were estimated for workers ages 18 years and older for each of the eight NORA sectors; as well as by population subgroups categorized by age, gender, race, ethnicity, health insurance, and education. Additional information has been made available to allow for extrapolation to the entire U.S. worker population during the 1997-2007 study period.

\section{Previous NHIS Occupational Morbidity Studies}

Previous studies have used the NHIS data to explore a range of occupational health issues, including: injury, smoking characteristics, health characteristics in the longest held occupation and industry, injuries in racial subgroups, cardiovascular disease and working women, impairments and chronic diseases in farmers, back injury and disability, workplace accommodations, AIDS knowledge among health care workers, and carpal tunnel syndrome [Behrens et al. 1994; Biddlecom et al. 1992; Brackbill et al. 1994a,b; Cooper et al. 1993; Guo et al. 1999; Hurwitz and Morgenstern 1997; La Rosa JH 1988; Nelson et al. 1994a,b; NIOSH 1980; Sterling and Weinkam 1989, 1990; Tanaka et al. 1995; Wagener and Winn 1991; Zwerling et al. 1997, 1998, 2003].

NIOSH colleagues Kaminski and Spirtas [NIOSH 1980] analyzed NHIS data and produced proportionate morbidity ratios (PMRs) from the 1969-74 NHIS surveys to examine the morbidity, disability, and reported health care use patterns for 498,580 individuals by industry. They did not look at trends over this relatively short time period. The highest specific disease conditions were reported for agriculture, furniture manufacturing, metal fabrication, railroad transport, repair services, amusement and recreational services, state and local government workers, and new workers; the highest disabilities were found for forestry and fisheries workers, certain manufacturers, medical and health services workers, and federal government employees; the greatest use of medical services was among metal industries, specific manufacturers, and railroad workers; the greatest morbidity was reported by private household service workers although they had less disability and use of medical services; overall manufacturing industries had the largest proportion of workers with work injuries and the service industries had the smallest. The authors pointed out that although some of the results confirmed previous studies, other results of their study revealed new associations of morbidity with particular industry/occupations of U.S. workers. These observations were possible because the NHIS survey design is not limited to a particular industry, occupation, or geographic area. Therefore, Kaminski and Spirtas [NIOSH 1980] suggested that NHIS data be used for surveillance of disease morbidity and mortality for U.S. workers, and recommended that its use for this purpose be explored further.

The Occupational Research Group at the University of Miami used the NHIS data from 1986-2007, with mortality follow-up through 2002, to evaluate various issues of health disparities among all U.S. workers, particularly among poor and minority worker subpopulations predominantly by occupational subcategory [Caban et al. 2005; Caban-Martinez et al. 2007a,b; Christ et al. 2007; Fleming et al. 2003; Fleming et al. 2007b; Gómez-Marin et al. 2004, 2005; Lee et al. 2004; Lee et al. 2006a,b; Lee et al. 2007a,b; McCollister et al. 2010]. They have evaluated occupational health disparities in terms of health behaviors, health insurance, obesity and exercise, occupational segregation, morbidity, and mortality in all U.S. workers, as well as morbidity and mortality in particular occupations and industry sectors. Overall, they have found that minority and blue collar workers are less likely to reported having health 
insurance, health screening (such as cancer screenings), and receiving health prevention information from their health care providers. At the same time, these workers are more likely to be obese, less likely to exercise, more likely to reported morbidity, and more likely to report risky drinking and smoking behaviors (See http://www.umiamiorg.com/ for online monographs and other documentation).

\section{Methods}

\section{The National Health Interview Survey (NHIS)}

Since 1957, the National Center for Health Statistics (NCHS) has administered the NHIS as a continuous multipurpose and multistage area probability in-person survey of the U.S. civilian non-institutionalized population living at addressed dwellings [Botman and Jack 1995; NCHS 1989, 2000]. The survey was authorized by Congress to obtain national estimates on disease, injury, impairment, disability, and related issues on a uniform basis for the U.S. population. The NHIS Survey has evolved over the years with a significant redesign in 1997.

\section{Survey Years 1997-2007}

The NHIS was completely redesigned in 1997 to collect key health information from a single randomly selected adult household member. In case the randomly selected household member is not home when the interviewer goes to the home, then the interviewer returns at a different date to interview this person. This strategy greatly enhances the reliability of acute and chronic condition assessment.

Data exist in three separate files: the Person, Sample Adult, and Sample Child. These files include both household and individual level information on various demographics and aspects of health. However, the data that exist in each of these files differ. For example, the Sample Adult file contains information on health conditions, physical and social activity limitations, psychological distress, and chronic conditions important risk factors (such as tobacco and alcohol use) among the adult randomly selected to be interviewed, while the Person file contains information on functional status and access to health care of all NHIS participants. Data on occupation and industry is only available in the Sample Adult file. For the survey years 1997-2007 of the NHIS, there were 196,924 adult participants currently employed at the time of the household interview (see table below). Annual response rates to the 1997-2007 adult core survey ranged from 69\% (in 2005) to 80\% (in 1997) [NCHS 2002a,b; NCHS 2003a,b; NCHS 2004a,b; NCHS 2005; NCHS 2006a,b; NCHS 2007].

Sample size for gender and age-group by ethnic or race subgroups National Health Interview Survey, 1997-2007

\begin{tabular}{|c|l|l|l|l|}
\hline \multirow{2}{*}{ Subgroup } & \multicolumn{2}{c|}{ Females } & \multicolumn{2}{c|}{ Males } \\
\cline { 2 - 5 } & $\mathbf{1 8 - 5 9}$ years & $\begin{array}{l}\mathbf{6 0} \text { years } \\
\text { and older }\end{array}$ & $\mathbf{1 8 - 5 9}$ years & $\begin{array}{l}\text { 60 years } \\
\text { and older }\end{array}$ \\
\hline Hispanic origin & & & & \\
\hline Hispanic/Latino & 14,908 & 679 & 17,526 & 807 \\
\hline Not Hispanic/Latino & 76,281 & 7,288 & 72,391 & 7,044 \\
\hline Race & & & & \\
\hline White & & & & \\
\hline Black/African American & 15,248 & 963 & 10,238 & 813 \\
\hline Unknown/multiple races & 5,691 & 270 & 6,321 & 340 \\
\hline & & & & \\
\hline Total & 91,189 & 7,967 & 89,917 & 7,851 \\
\hline
\end{tabular}




\section{Morbidity and disability prevalence measures}

The tables below summarize the questions administered consistently from the NHIS for the period 1997-2007. A comprehensive summary of these questions is found in Appendix 1.

These questions include:

\begin{tabular}{|l|l|}
\hline \multicolumn{2}{|c|}{ Demographic subgroups } \\
\hline Variable & \multicolumn{1}{c|}{ Question(s) } \\
\hline Gender & Are you male or female? \\
\hline Age & How old are you? (years) \\
\hline Race & What races do you consider yourself to be? \\
\hline Ethnicity & $\begin{array}{l}\text { Do you consider yourself to be Hispanic or Latino? Hispanic includes: } \\
\text { Puerto Rican, Cuban, Dominican, Mexican, Central/South American, } \\
\text { other Latin American, other Hispanic }\end{array}$ \\
\hline Insurance & Are you covered by health insurance or any other health care plan? \\
\hline Education & What is the highest level of education that you have completed? \\
\hline
\end{tabular}

As noted under Statistical methods below, estimates are provided for population subgroups based on responses to these questions on gender, age, ethnicity, insurance coverage and education.

Since the 1970s health planners have used various metrics to gauge population health status. In recent years, both Healthy People 2000 and 2010 have included measures that seek to characterize the quality of life, and efforts within CDC seek to track health days as measured by the NHIS and the CDC's Behavioral Risk Factor Survey [CDC 2000]. This report provides data on self-reported health status, which is supplemented with data on bed day disability and lost work days among the employed U.S. population.

\begin{tabular}{|l|l|}
\hline \multicolumn{2}{|l|}{ Health status } \\
\hline Variable & \multicolumn{1}{c|}{ Question(s) } \\
\hline Health Last Year & $\begin{array}{l}\text { Compared with 12 MONTHS AGO, would you say your health is } \\
\text { (better, worse, or about the same)? }\end{array}$ \\
\hline $\begin{array}{l}\text { Self Rated } \\
\text { Health }\end{array}$ & $\begin{array}{l}\text { Would you say health in general is excellent, very good, good, fair, or } \\
\text { poor? }\end{array}$ \\
\hline Bed Day & $\begin{array}{l}\text { During the PAST 12 MONTHS, that is, since [12 month ref date], } \\
\text { ABOUT how many days did illness or injury keep you in bed for more } \\
\text { than half of the day? (Include days while an overnight patient in a } \\
\text { hospital). }\end{array}$ \\
\hline Lost Work Day & $\begin{array}{l}\text { During the PAST 12 MONTHS, that is, since [12 month ref date], } \\
\text { ABOUT how many days did you miss work at a job or business because } \\
\text { of illness or injury (do not include maternity leave)? }\end{array}$ \\
\hline
\end{tabular}


The NHIS provides NIOSH with the opportunity to describe working populations relative to more subtle aspects of physical activity limitations or disability. These questions permit us to examine a proportion of employed workers who labor under physical limitations; require the use of special equipment; or have hearing or visual impairment.

\begin{tabular}{|c|c|}
\hline \multicolumn{2}{|r|}{ Physical activity limitations } \\
\hline Variable & Question(s) \\
\hline $\begin{array}{l}\text { Special } \\
\text { Equipment }\end{array}$ & $\begin{array}{l}\text { Do you now have any health problem that requires you to use special } \\
\text { equipment, such as a cane, a wheelchair, a special bed, or a special } \\
\text { telephone? }\end{array}$ \\
\hline Limitations & $\begin{array}{l}\text { NHIS recode based on all the } 12 \text { NHIS questions on activity limitations: } \\
\text { How difficult it is for you to: } \\
\text { o walk } 1 / 4 \text { mile w/o special equipment? } \\
\text { o Climb } 10 \text { steps w/o special equipment } \\
\text { o Stand } 2 \text { hours w/o special equipment } \\
\text { o Sit } 2 \text { hours w/o special equipment } \\
\text { o Stoop, bend or kneel w/o special equipment } \\
\text { o Reach over w/o special equipment } \\
\text { o Grasp small objects w/o special equipment } \\
\text { o Lift/carry } 10 \text { lbs w/o special equipment } \\
\text { o Push large objects w/o special equipment } \\
\text { o Go out to events w/o special equipment } \\
\text { o Participate in social activities w/o special equipment } \\
\text { o Relax at home w/o special equipment }\end{array}$ \\
\hline $\begin{array}{l}\text { Hearing } \\
\text { Impairment }\end{array}$ & $\begin{array}{l}\text { Which statement best describes your hearing (without a hearing aid): } \\
\text { good, a little trouble, a lot of trouble, deaf? }\end{array}$ \\
\hline $\begin{array}{l}\text { Visual } \\
\text { Impairment }\end{array}$ & $\begin{array}{l}\text { Based on two questions: } \\
\text { o Do you have trouble seeing, even when wearing glasses or contact } \\
\text { lenses? and } \\
\text { o Are you blind or unable to see at all? }\end{array}$ \\
\hline
\end{tabular}


Establishment-based surveys of occupational illness provide limited insight on the prevalence of many chronic diseases and mental health problems. For the years 1997-2007 the NHIS permits one to pool data so as to estimate and describe the prevalence of cancer, hypertension, heart disease, asthma, diabetes, and severe psychological distress.

\begin{tabular}{|c|c|}
\hline \multicolumn{2}{|r|}{ Health and chronic conditions } \\
\hline Variable & Question(s) \\
\hline Cancer & $\begin{array}{l}\text { Have you EVER been told by a doctor or other health professional that } \\
\text { you had cancer or a malignancy of any kind? (yes/no) }\end{array}$ \\
\hline Hypertension & $\begin{array}{l}\text { Have you EVER been told by a doctor or other health professional that } \\
\text { you have had hypertension, also called high blood pressure? }\end{array}$ \\
\hline Heart Disease & $\begin{array}{l}\text { Have you EVER been told by a doctor or other health professional that } \\
\text { you had heart disease? Based on NHIS questions of specific diseases: } \\
\text { o Coronary heart disease } \\
\text { o Angina } \\
\text { o Heart attack } \\
\text { o Any kind of heart condition or heart disease }\end{array}$ \\
\hline Asthma & $\begin{array}{l}\text { Have you EVER been told by a doctor or other health professional that } \\
\text { you had asthma? }\end{array}$ \\
\hline Diabetes & $\begin{array}{l}\text { Have you EVER been told by a doctor or other health professional that } \\
\text { you have diabetes or sugar diabetes? }\end{array}$ \\
\hline $\begin{array}{l}\text { Severe } \\
\text { Psychological } \\
\text { Distress }\end{array}$ & $\begin{array}{l}\text { Based on } 6 \text { NHIS questions: "During the past } 30 \text { days how often did you } \\
\text { feel...?" } \\
\text { o so sad that nothing could cheer you up? } \\
\text { o nervous? } \\
\text { o restless or fidgety? } \\
\text { o hopeless? } \\
\text { o that everything was an effort? } \\
\text { o worthless? }\end{array}$ \\
\hline
\end{tabular}


The health of workers depends on access to and use of health care services, both of which are essential to maintaining the productive capabilities of the labor force. These questions provide important data on access to primary medical and dental care, and the use of hospital emergency rooms and surgical procedures.

\begin{tabular}{|l|l|}
\hline \multicolumn{2}{|c|}{ Health care utilization } \\
\hline Variable & \multicolumn{1}{c|}{ Question(s) } \\
\hline $\begin{array}{l}\text { Seen Primary } \\
\text { Proalth care }\end{array}$ & $\begin{array}{l}\text { During the past 12 months, have you seen a primary health care provider } \\
\text { (any of the following): } \\
\text { o Ob/GYN } \\
\text { o general doctor }\end{array}$ \\
\hline Dental & $\begin{array}{l}\text { About how long has it been since you last saw or talked to a dentist? } \\
\text { Include all types of dentists, such as orthodontists, oral surgeons, and all } \\
\text { other dental specialists, as well as dental hygienists. }\end{array}$ \\
\hline Surgery & $\begin{array}{l}\text { During the PAST 12 MONTHS, have you had SURGERY or other surgi- } \\
\text { cal procedures either as an inpatient or an outpatient? This includes both } \\
\text { major surgery and minor procedures such as setting bones or removing } \\
\text { growths. }\end{array}$ \\
\hline $\begin{array}{l}\text { Emergency } \\
\text { Room Visit }\end{array}$ & $\begin{array}{l}\text { During the PAST 12 MONTHS, HOW MANY TIMES have you gone to } \\
\text { a HOSPITAL EMERGENCY ROOM for your health? }\end{array}$ \\
\hline
\end{tabular}

Health promotion and disease prevention for many chronic diseases emphasize the importance of smoking cessation, and moderating alcohol consumption. Few would question that regular physical activity is important for maintaining a healthy body, enhancing psychological well-being, and preventing premature death. Yet, while we have statistics that estimate more than half of adults in the United States are overweight or obese, we have limited data on how these factors vary among employed workers and industry. Immunizations can prevent disability or severe health effects from infectious diseases among individuals and help control the spread of infections within communities. Recent campaigns in the U.S. have focused on the importance of the spread of influenza by and among selected high-risk occupational groups, as the workplace is recognized as an element of community-based immunization programs. The NHIS permits one to pool data so as to estimate and describe the prevalence of these factors among population subgroups within industry sectors. 


\begin{tabular}{|c|c|}
\hline \multicolumn{2}{|r|}{ Health risk factors or behaviors } \\
\hline Variable & $\begin{array}{l}\text { Question(s) } \\
\end{array}$ \\
\hline Smoking status & $\begin{array}{l}\text { Is the individual a never smoker, former smoker, or current smoker? } \\
\text { Based on the NHIS questions: } \\
\text { o Have you smoked at least } 100 \text { cigarettes in your entire life? } \\
\text { o Do you now smoke cigarettes every day, some days, or not at all? }\end{array}$ \\
\hline Drinking status & $\begin{array}{l}\text { Based on three questions related to historical and current alcohol use } \\
\text { patterns: } \\
\text { o In your ENTIRE LIFE, have you had at least } 12 \text { drinks of any type of } \\
\text { alcoholic beverage? } \\
\text { o In ANY ONE YEAR, have you had at least } 12 \text { drinks of any type of } \\
\text { alcoholic beverage? } \\
\text { o In the PAST YEAR, how often did you drink any type of alcoholic } \\
\text { beverage? }\end{array}$ \\
\hline $\begin{array}{l}\text { Body Mass } \\
\text { Index (BMI) } \\
\text { (obesity) }\end{array}$ & $\begin{array}{l}\text { NHIS Recoded variable based on NHIS variables: } \\
\text { o Self-reported weight without shoes (pounds) (AWEIGHTP) } \\
\text { o Self-reported total height in inches (AHEIGHT) }\end{array}$ \\
\hline $\begin{array}{l}\text { Leisure Time } \\
\text { Physical Activity }\end{array}$ & $\begin{array}{l}\text { Did the individual meet CDC Health People } 2010 \text { recommendations for } \\
\text { leisure time physical activity (i.e. engaged or light-moderate activity for } \\
\geq 30 \text { minutes } \geq 5 \text { times/week or "vigorous activity" } \geq 20 \text { minutes } \geq 3 \\
\text { times per week or both). } \\
\text { Based on NHIS questions: } \\
\text { o Frequency of light/moderate activity (times per week)? } \\
\text { o Duration of light/moderate activity (in minutes)? } \\
\text { o Frequency vigorous activity (times per week)? } \\
\text { o Duration of vigorous activity (in minutes)? }\end{array}$ \\
\hline HIV/AIDS Test & $\begin{array}{l}\text { The next questions are about the test for HIV. Have you ever been tested } \\
\text { for HIV? }\end{array}$ \\
\hline $\begin{array}{l}\text { Influenza } \\
\text { Vaccine }\end{array}$ & $\begin{array}{l}\text { During the past } 12 \text { months, have you had a flu shot? A flu shot is usually } \\
\text { given in the fall and protects against influenza for the flu season. }\end{array}$ \\
\hline $\begin{array}{l}\text { Pneumococcal } \\
\text { Vaccine }\end{array}$ & $\begin{array}{l}\text { Have you ever had a pneumonia shot? This shot is usually given only } \\
\text { once or twice in a person's lifetime and is different from the flu shot. It } \\
\text { is also called the pneumococcal vaccine. }\end{array}$ \\
\hline
\end{tabular}




\section{Employment and NORA Sector}

Beginning in 1997, employment was defined as having worked during the week prior to the NCHS survey and asked of all Sample Adult NHIS participants 18 years and older. This definition includes paid as well as unpaid work. The NHIS employs U.S. Census Occupational and Industrial Codes to classify workers [NCHS 1993a]. NCHS then recoded the Census Occupational Codes into 13 broad categories, and 41 more specialized categories.

For this analysis employed workers were aggregated by codes into eight industrial sector classifications corresponding to National Occupational Research Agenda (NORA) sectors [Soderholm 2006]. Of note, these industrial groupings are heterogeneous in that each group may include workers engaged in both blue- and white-collar occupational activities. Sector definitions follow the North American Industry Classification System (NAICS), which has replaced the U.S. Standard Industrial Classification (SIC) system. More information about NAICS can be found on the U.S. Census Bureau [http://www.census.gov/eos/www/naics/]. NAICS provides definitions for 20 sectors which NIOSH aggregated into eight sector groups (see Background and introduction).

For survey years NHIS 1997-2004, the industry codes do not translate directly into the NORA sectors. A conversion process was developed to translate the codes, the details of which are provided in Appendices 2 and 3.

\section{Statistical Methods}

Because of the multi-stage sampling design, all analyses were performed with adjustment for sample weights and design effects using the SUDAAN and SAS statistical packages [Research Triangle Institute 2004]. These analyses also took into account relatively minor sample design modifications implemented in 2006 due to smaller sample size recruitment targets [NCHS 2008]. The sample weights used were those required for the analysis of data from combined survey years and were calculated as originally specified by Botman and currently recommended by the NCHS [Botman and Jack 1995; NCHS 2008]. Sample weights are also used to estimate the number of workers in the U.S. with various health conditions. In some cases these values will be underestimates due to either (1) the presence missing data for the condition of interest (e.g., respondent did not respond to a chronic disease question), or (2) in the case of stratified analyses, there are missing values for the stratification variable (e.g., educational attainment).

Estimates are presented in a table format for All U.S. workers and all workers employed in the Healthcare and Social Assistance sector (and are available for each of the remaining seven NORA sectors). Within each table, estimates are presented for all workers identified with the NORA sector subpopulation, and then by subgroups of age, gender, race, ethnicity, health insurance status, and education. Each table provides the NHIS sample size and the estimated employed U.S. worker population by each of these subgroups. Estimated standard errors (SEs) are included in these tables, which can be used to compute confidence intervals.

\section{Limitations}

The NHIS data are collected cross-sectionally every year, thus causal inference is difficult. Nevertheless, the fact that the NHIS collects data from a representative sample of the U.S. civilian population annually makes it a powerful surveillance tool to look at pooled data for a range of factors in all U.S. civilian workers. 
The data from the NHIS are entirely self-reported which can lead to biases of both under- and over-reporting. For example, weight and height were collected in a self-reported or proxy fashion, which could have led to less precision in the calculation of the BMI. Previous research has suggested that people tend to under-report their weight and over-report their height, leading to the underestimation of BMI; additionally, the degree of under- and over-reporting varies as a function of age, gender, race, ethnicity, and social class [Caban et al. 2005; Engstrom et al. 2003; Kuczmarski et al. 2001; Spencer et al. 2002].

Some of the NORA sectors, particularly Mining and to a lesser extent Agriculture, Forestry and Fishing, have relatively few workers. Consequently, small sample sizes may limit one's ability to produce estimates for less prevalent chronic conditions (e.g., cancer, psychological distress) or impairments, as well as inferences and conclusions users derive from these estimates. This is most apparent where one stratifies by the different demographic subgroups (e.g., race, ethnicity, or age group).

The figures display and reflect the tabulated prevalence (percentage) values for these population samples. For a small number of figures, the response values displayed may include symbols indicating (1) no data available, which occurs where the population subgroup sample is zero (symbol (---)); (2) the computed quantity or value is greater than 0.0 but less than $0.05 \%$ (symbol (0.0)); and (3) there were no cases in that particular cell, and thus no response value estimated (symbol $(-)$ ) is zero quantity.

The NHIS does not consistently collect data on occupational exposure or direct occupational health effects with the exception of work loss days. Of note, NCHS has collaborated and conducted occupational supplements in the past [NCHS 1990,1993b]. NIOSH sponsored an Occupational Health Supplement to the 2010 NHIS. An advanced statistical report of these data is expected in the 3rd quarter of 2011.

\section{Summary of estimates for the workers in the Healthcare and Social Assistance sector}

\section{Population and demographic Overview for 1997-2007}

\section{All U.S. Workers}

From 1997-2007, 196,924 US workers age 18 years and older (representing an estimated 126,898,030 US workers annually) participated in a probability sampling of the entire non-institutionalized US population (See Table 1). Of the U.S. workers, there were approximately equal percentages of men $(54.0 \%)$ and women (46.0\%) during this time period. The majority of the U.S. workers self-identified as White $(83.0 \%)$ with $11.1 \%$ Black and 5.9\% "Other" races, while $11.8 \%$ were Hispanic and $88.2 \%$ Non-Hispanic. The majority (83.5\%) of U.S. workers were in the 25-64 year old age group with $13.4 \%$ in the 18-24 year old age group and 3.1\% in the 65 years and older group. The majority (59.4\%) of U.S. workers had more than a high school education, with $11.7 \%$ having less than a high school education and $28.4 \%$ having completed high school. Although $83.8 \%$ of U.S. workers reported having health insurance, $16.0 \%$ did not have health insurance.

\section{Healthcare and Social Assistance}

From 1997-2007, an estimated 16,548,227 U.S. workers age 18 years and older worked annually in the Healthcare and Social Assistance sector (Table 1). Of the entire U.S. workforce, approximately $13.0 \%$ work in the Healthcare and Social Assistance sector. In this sector, the majority of workers were women (77.5\%) with only $22.5 \%$ men during this time period. The majority of the workers in this sector were self-identified as White (78.4\%) with 15.8\% Black and 5.8\% "Other" races, while 8.3\% were Hispanic and 91.7\% Non-Hispanic. The majority (86.1\%) of workers were in the 25-64 year old age group with 10.4\% in the 18-24 year old age group and 3.5\% in the 65 years and older group. In this sector, the majority (71.0\%) of workers had more than a high school education, with $6.9 \%$ having less than a high school education and $21.6 \%$ having completed high school. Finally, although $88.6 \%$ of workers in this sector reported having health insurance, $11.1 \%$ did not have health insurance. 
The following summary statements on population, disability, and morbidity measures are based on data found in Table 1 (page 41) and Table 2 (pages 42-43).

\section{Health Status}

An estimated 6.0\% or about 993,000 NORA Healthcare and Social Assistance sector workers reported their health status was worse when compared with 12 months prior.

An estimated 5.8\% or about 960,000 million NORA Healthcare and Social Assistance sector workers reported their health status in general was fair to poor.

NORA Healthcare and Social Assistance sector workers reported an estimated mean of 2.2 bed disability days during the past 12 months; $28.5 \%$ or about 4.7 million workers reported 2 or more bed disability days. NORA Healthcare and Social Assistance sector workers reported an estimated mean of 4.2 work loss days during the past 12 months; $12.9 \%$ or about 2.1 million workers reported 6 or more work loss days.

\section{Physical Activity Limitations}

An estimated 1.4\% or about 232,000 NORA Healthcare and Social Assistance sector workers reported having a health problem that required the use of special equipment.

An estimated $25.1 \%$ or about 4.2 million NORA Healthcare and Social Assistance sector workers reported experiencing any functional limitations in any of 12 activities.

An estimated $9.9 \%$ or about 1.6 million NORA Healthcare and Social Assistance sector workers reported some degree of hearing impairment.

An estimated $7.7 \%$ or about 1.3 million NORA Healthcare and Social Assistance sector workers reported some degree of visual impairment.

\section{Health and Chronic Conditions}

An estimated $4.8 \%$ or about 794,000 NORA Healthcare and Social Assistance sector workers reported ever being told by a doctor or other health professional that they had cancer or a malignancy of any kind.

An estimated $19.7 \%$ or about 3.3 million NORA Healthcare and Social Assistance sector workers reported ever being told by a doctor or other health professional that they had ever had hypertension.

An estimated $7.6 \%$ or about 1.3 million NORA Healthcare and Social Assistance sector workers reported ever being told by a doctor or other health professional that they had had heart disease (including Coronary heart disease, Angina, Heart attack, or any kind of heart condition or heart disease).

An estimated $11.0 \%$ or about 1.8 million NORA Healthcare and Social Assistance sector workers reported ever being told by a doctor or other health professional that they had asthma.

An estimated 4.6\% or about 761,000 NORA Healthcare and Social Assistance sector workers reported ever being told by a doctor or other health professional that they had diabetes (or sugar diabetes).

An estimated $0.6 \%$ or about 99,000 NORA Healthcare and Social Assistance sector workers reported experiencing in the previous 30 days symptoms of severe psychological distress. 


\section{Health Care Utilization}

An estimated $20.6 \%$ or about 3.4 million NORA Healthcare and Social Assistance sector workers reported not having seen a primary health care provider during the past 12 months

An estimated $27.9 \%$ or about 4.6 million NORA Healthcare and Social Assistance sector workers reported not having seen or talked to a dentist during the past 12 months.

An estimated $12.6 \%$ or about 2.1 million NORA Healthcare and Social Assistance sector workers reported having surgery or other surgical procedures as an inpatient or outpatient during the past 12 months.

An estimated $18.5 \%$ or about 3.1 million NORA Healthcare and Social Assistance sector workers reported having made one or more hospital emergency room visits during the past 12 months.

\section{Health Risk Factors or Behaviors}

An estimated $18.8 \%$ or about 3.1 million NORA Healthcare and Social Assistance sector workers reported being current smokers.

An estimated $64.8 \%$ or about 10.7 million NORA Healthcare and Social Assistance sector workers reported being current alcohol drinkers.

An estimated $25.0 \%$ or about 4.1 million NORA Healthcare and Social Assistance sector workers reported a combination of height and weight consistent with obesity.

An estimated $65.6 \%$ or about 10.9 million NORA Healthcare and Social Assistance sector workers reportedly did not achieve CDC recommended leisure time levels of physical activity.

An estimated 47.0 or about 7.8 million NORA Healthcare and Social Assistance sector workers reported ever being tested for HIV.

An estimated $64.5 \%$ or about 10.7 million NORA Healthcare and Social Assistance sector workers reported not receiving an influenza vaccination.

An estimated $68.3 \%$ or 880,000 NORA Healthcare and Social Assistance sector workers 60 years and older reported never receiving a pneumococcal vaccination. 


\section{Figures}

\section{Prevalence of a reported decline in health when compared to health status 12 months prior estimated for workers 18 years and older}
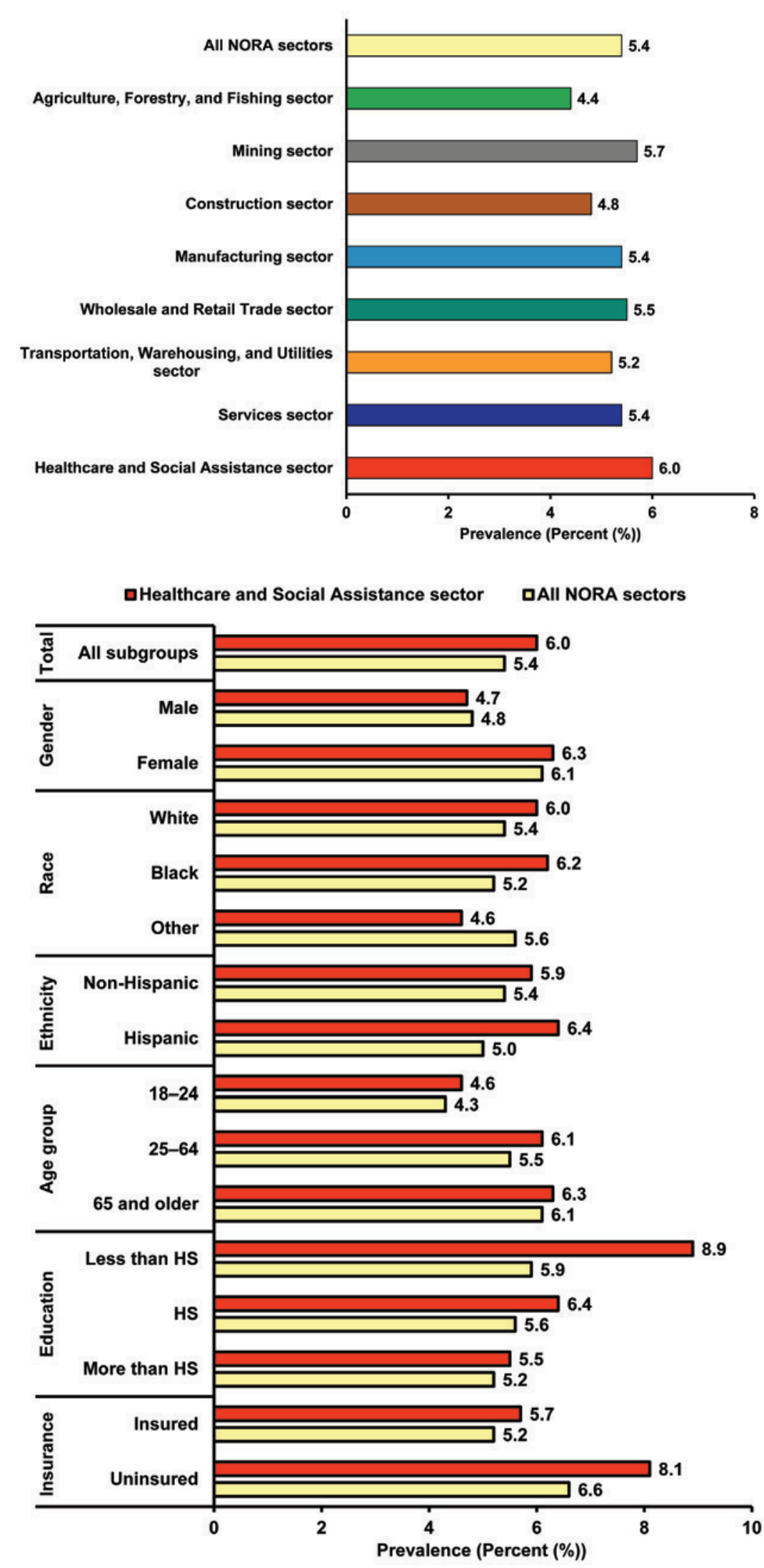

Figure 1a. Workers 18 years and older by NORA sectors, National Health Interview Survey, 1997-2007. An estimated $5.4 \%$ of all employed U.S. workers reported their current health was worse when compared to their health status 12 months prior (see Table 2 , page 42 , and Tables 3 and 4 , pages 44-45). Among the NORA sectors, Healthcare and Social Assistance sector workers reported the highest decline in health status compared 12 months prior $(6.0 \%)$, while Agriculture, Forestry, and Fishing sector workers reported the lowest (4.4\%).

Figure 1b. Workers 18 years and older, Healthcare and Social Assistance sector and All NORA sectors, National Health Interview Survey, 1997-2007.

An estimated $6.0 \%$ of workers employed in the Healthcare and Social Assistance sector reported their current health was worse when compared to their health status 12 months prior. Among the subgroups, workers with less than a high school education reported the highest prevalence of a decline in health status compared 12 months prior (8.9\%), while workers of "Other" race and those 18-24 years of age reported the lowest (4.6\%) (see Table 4, page 45). Among all U.S. workers, uninsured workers reported the highest prevalence of a decline in health status compared 12 months prior (6.6\%), while workers 18-24 years of age reported the lowest (4.3\%) (see Table 3, page 44). 


\section{Prevalence of fair or poor self-rated health status estimated for workers $\mathbf{1 8}$ years and older}

Figure 2a. Workers 18 years and older by NORA sectors, National Health Interview Survey, 1997-2007. An estimated $5.3 \%$ of all employed U.S. workers reported their self-rated health status was fair or poor (see Table 2, page 42, and Tables 5 and 6 , pages 46-47). Among the NORA sectors, Mining sector workers reported the highest prevalence of fair or poor self-rated health status $(6.5 \%)$, while Services sector workers reported the lowest (4.9\%).

Figure 2b. Workers 18 years and older, Healthcare and Social Assistance sector and All NORA sectors, National Health Interview Survey, 1997-2007.

An estimated $5.8 \%$ of workers employed in the Healthcare and Social Assistance sector reported their selfrated health status was fair or poor. Among the subgroups, workers with less than a high school education reported the highest prevalence of fair or poor self-rated health status (16.4\%), while workers $18-24$ years of age reported the lowest (2.8\%) (see Table 6, page 47). Among all U.S. workers, those with less than a high school education reported the highest prevalence of fair or poor self-rated health status $(11.2 \%)$, while workers 18-24 years of age reported the lowest (2.7\%). Uninsured workers reported nearly twice the rate of fair or poor self-rated health status relative to insured workers ( $8.1 \%$ vs. $4.8 \%$ ) (see Table 5, page 46).
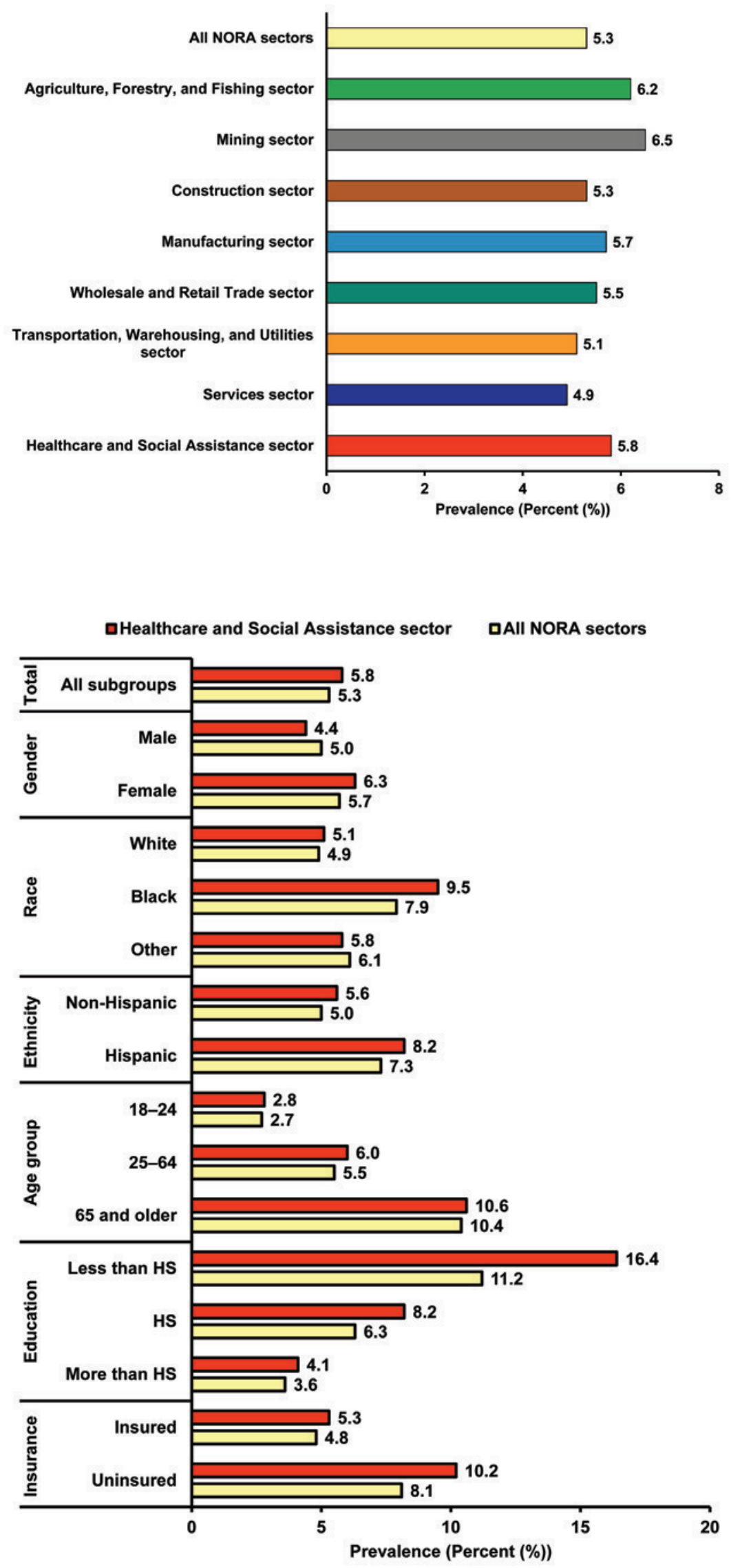
Mean number of bed disability days during the past 12 months estimated for workers 18 years and older

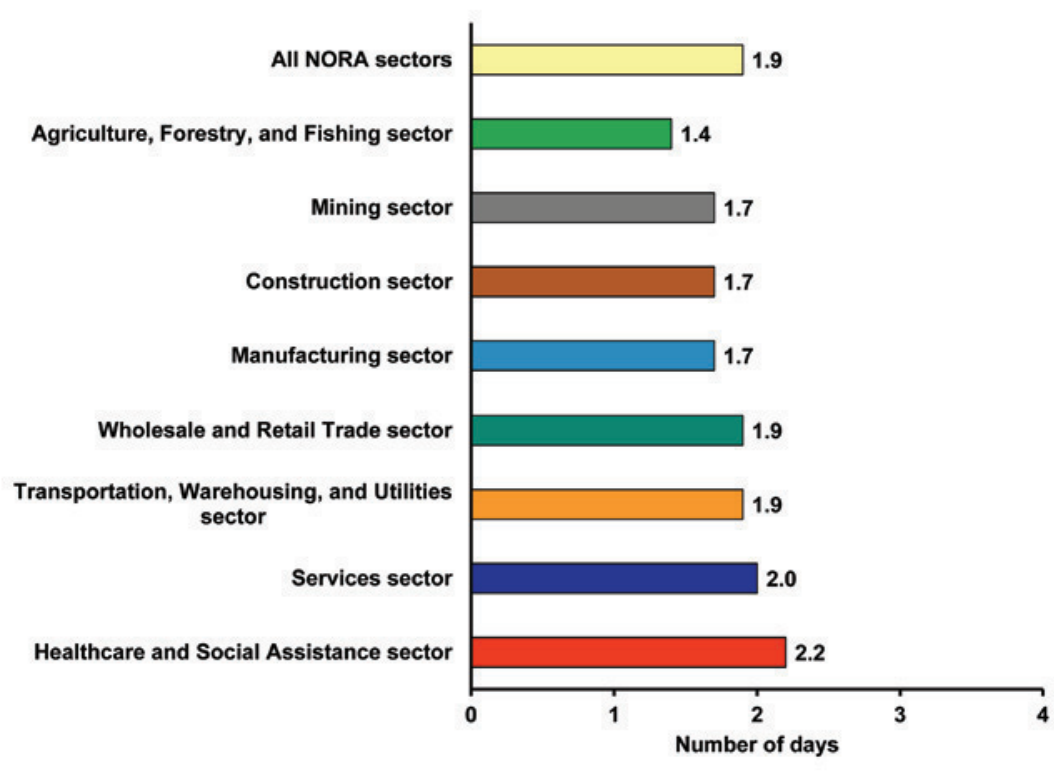

口Healthcare and Social Assistance sector QAll NORA sectors

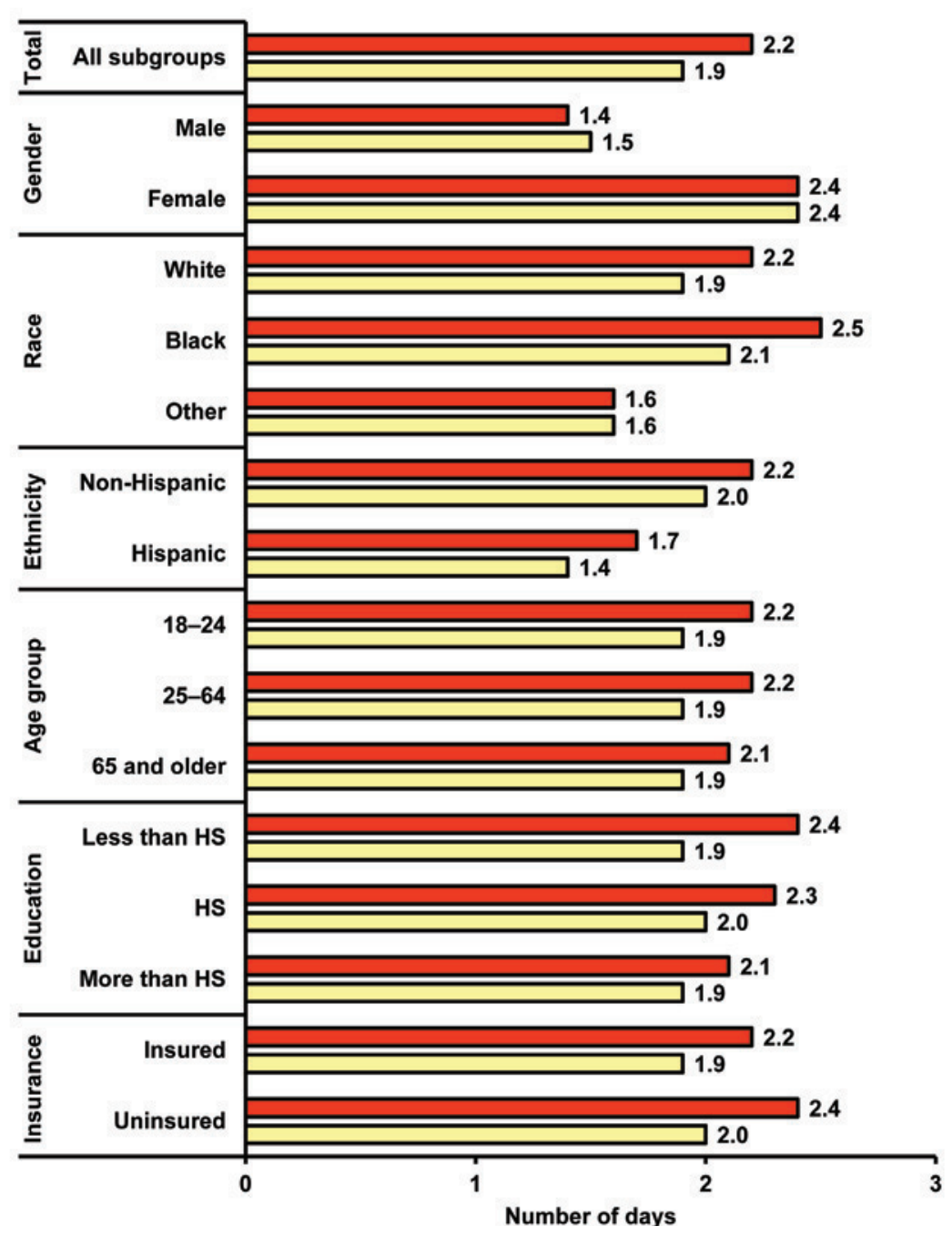

Figure 3a. Workers 18 years and older by NORA sectors, National Health Interview Survey, 1997-2007. Employed U.S. workers reported an estimated mean of 1.9 bed disability days during the past 12 months (see Table 2, page 42, and Tables 7 and 8, pages 48-49). Among the NORA sectors, Healthcare and Social Assistance sector workers reported the highest mean number of bed disability days during the past 12 months ( 2.2 bed disability days), that is days in bed for half a day or longer because of illness or injury, while Agriculture, Forestry, and Fishing sector workers reported the lowest (1.4 bed disability days).

Figure 3b. Workers 18 years and older, Healthcare and Social Assistance sector and All NORA sectors, National Health Interview Survey, 1997-2007.

Workers employed in the Healthcare and Social Assistance sector reported an estimated mean of 2.2 bed disability days during the past 12 months. Among the subgroups, Black workers reported the highest mean number of bed disability days during the past 12 months ( 2.5 bed disability days), while male workers reported the lowest (1.4 bed disability days) (see Table 8 , page 49). Among all U.S. workers, female workers reported the highest mean number of bed disability days during the past 12 months ( 2.4 bed disability days), while Hispanic workers reported the lowest (1.4 bed disability days) (see Table 7, page 48). 


\section{Prevalence of having $\mathbf{2}$ or more bed disability days during the past $\mathbf{1 2}$ months estimated for workers 18 years and older}

Figure 4a. Workers 18 years and older by NORA sectors, National Health Interview Survey, 1997-2007. An estimated $25.3 \%$ of employed U.S. workers reported having had at least 2 or more bed disability days during the past 12 months (see Table 2 , page 42 , and Tables 9 and 10, pages 50-51). Among the NORA sectors, Healthcare and Social Assistance sector workers reported the highest prevalence of two or more bed disability days during the past 12 months (28.5\%), while Agriculture, Forestry, and Fishing sector workers reported the lowest (18.1\%).

Figure 4b. Workers 18 years and older, Healthcare and Social Assistance sector and All NORA sectors, National Health Interview Survey, 1997-2007.

An estimated $28.5 \%$ of workers employed in the Healthcare and Social Assistance sector reported having had at least 2 or more bed disability days during the past 12 months. Among the subgroups, workers 18-24 years of age reported the highest prevalence of 2 or more bed disability days during the past 12 months (32.2\%), while workers 65 years of age or older reported the lowest (17.0\%) (see Table 10, page 51). Among all U.S. workers, female workers reported the highest prevalence of 2 or more bed disability days during the past 12 months (30.5\%), while workers 65 years of age and older reported the lowest (17.5\%). Rates for these older workers 65 years and older were lower than the rates for younger workers, 18-24 years [27.2\%] and $25-64$ years [25.2\%], respectively (see Table 9, page 50).
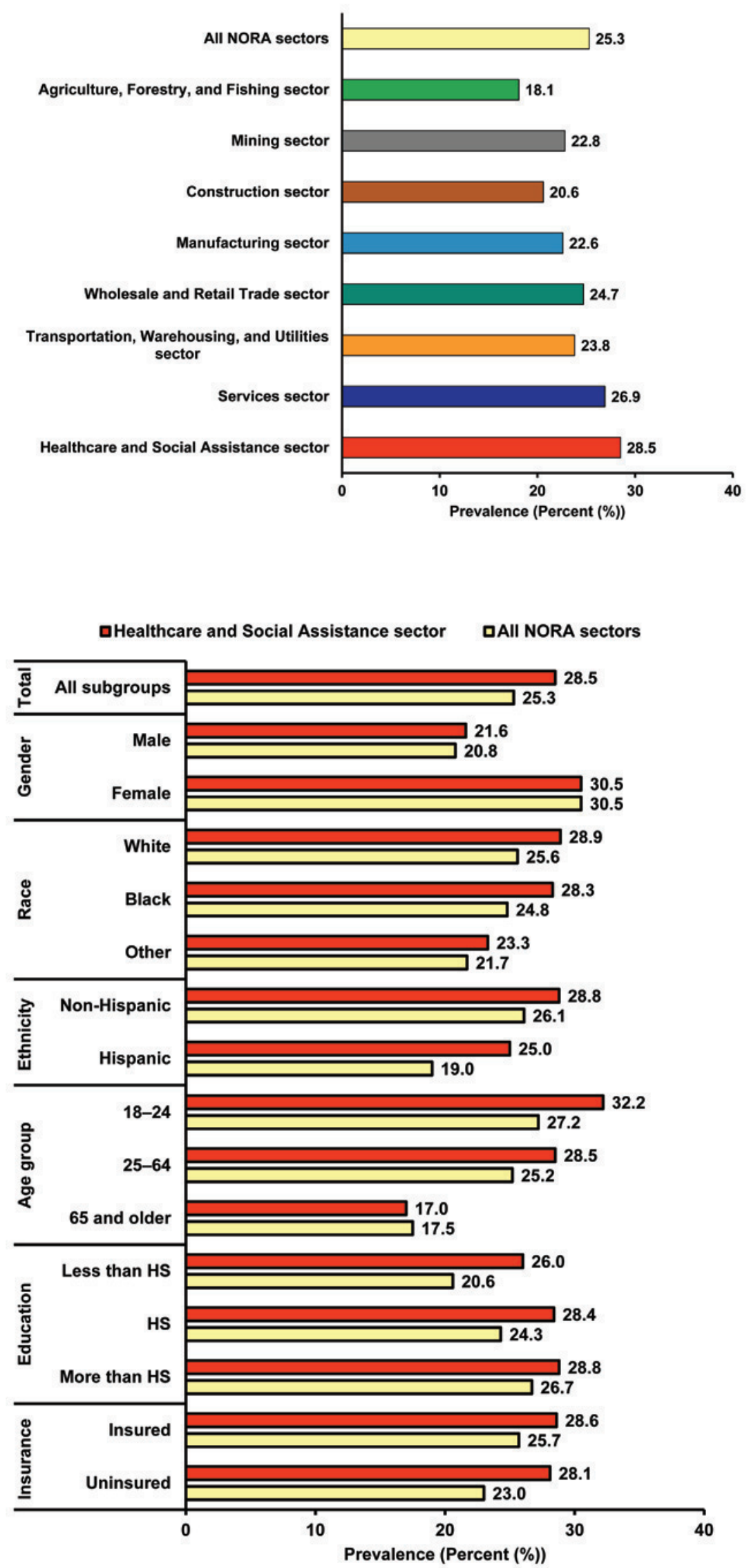


\section{Mean number of work loss days during the past 12 months estimated for workers 18 years} and older

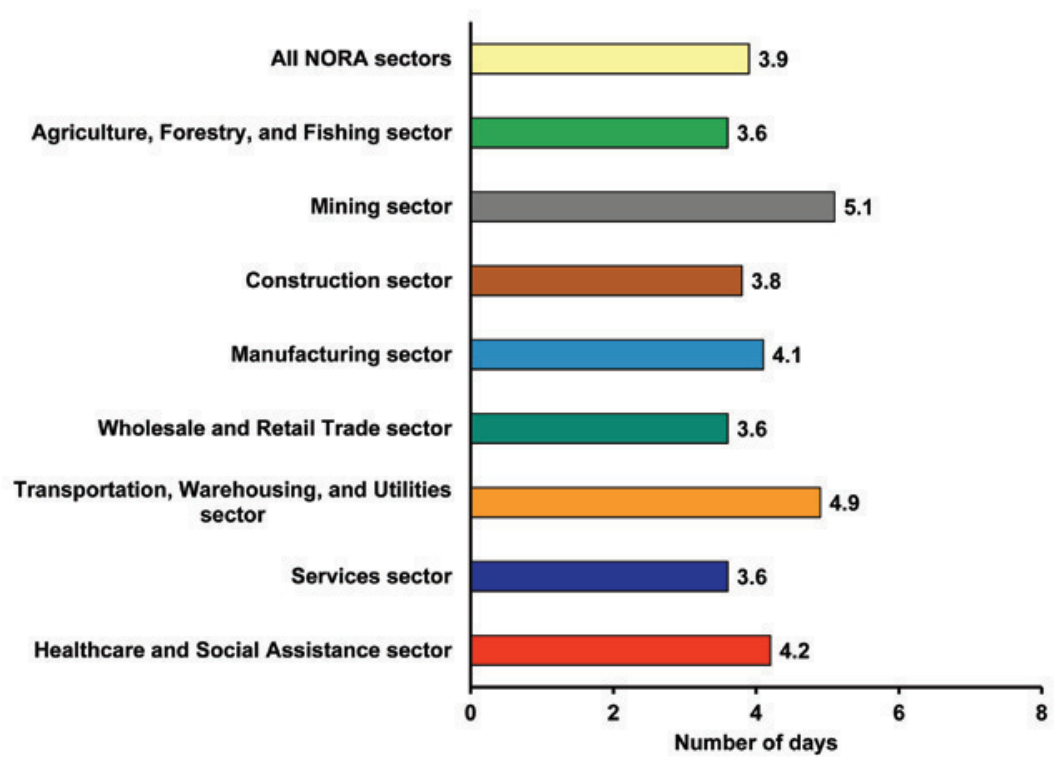

口Healthcare and Social Assistance sector

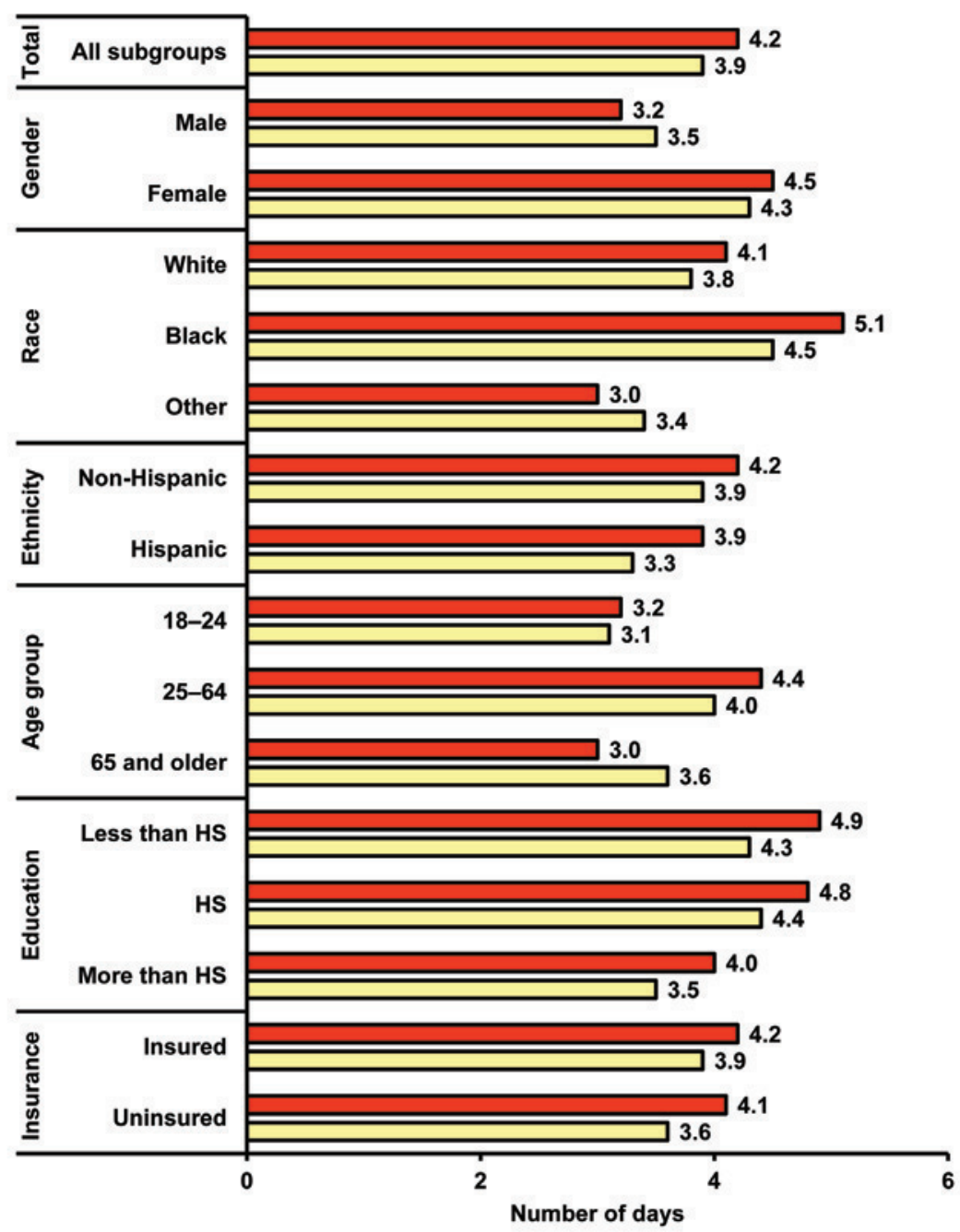

Figure 5a. Workers 18 years and older by NORA sectors, National Health Interview Survey, 1997-2007. Employed U.S. workers reported an estimated mean of 3.9 work loss days during the past 12 months (see Table 2, page 42, and Tables 11 and 12, pages 52-53). Among the NORA sectors, Mining sector workers reported the highest mean number of work loss days during the past 12 months (5.1 work loss days), while Agriculture, Forestry, and Fishing sector workers, Services sector workers, and Wholesale and Retail Trade sector workers reported the lowest (3.6 work loss days).

Figure 5b. Workers 18 years and older, Healthcare and Social Assistance sector and All NORA sectors, National Health Interview Survey, 1997-2007.

Workers employed in the Healthcare and Social Assistance sector reported an estimated mean of 4.2 work loss days during the past 12 months. Among the subgroups, Black workers reported the highest mean number of work loss days during the past 12 months (5.1 work loss days), while workers of "Other" race and those 65 years of age or older reported the lowest (3.0 work loss days) (see Table 12, page 53). Among all U.S. workers, Black workers reported the highest mean number of work loss days during the past 12 months (4.5 work loss days), while workers 18-24 years of age reported the lowest (3.1 work loss days) (see Table 11, page 52). 


\section{Prevalence of 6 or more work loss days during the past 12 months estimated for workers 18 years and older}

Figure 6a. Workers 18 years and older by NORA sectors, National Health Interview Survey, 1997-2007.

An estimated $11.1 \%$ of employed U.S. workers reported having had $\geq 6$ work loss days during the past 12 months (see Table 2, page 42, and Tables 13 and 14, pages 54-55). Among the NORA sectors, Transportation, Warehousing, and Utilities sector workers reported the highest prevalence of $\geq 6$ work loss days during the past 12 months (13.1\%), while Agriculture, Forestry, and Fishing sector workers reported the lowest $(8.8 \%)$.

Figure 6b. Workers 18 years and older, Healthcare and Social Assistance sector and All NORA sectors, National Health Interview Survey, 1997-2007.

An estimated $12.9 \%$ of workers employed in the Healthcare and Social Assistance sector reported having had $\geq 6$ work loss days during the past 12 months. Among the subgroups, Black workers reported the highest prevalence of $\geq 6$ work loss days during the past 12 months (15.1\%), while male workers reported the lowest (9.7\%) (see Table 14, page 55). Among all U.S. workers, female workers reported the highest prevalence of $\geq 6$ work loss days during the past 12 months (13.0\%), while Hispanic workers reported the lowest $(9.2 \%)$ (see Table 13 , page 54).
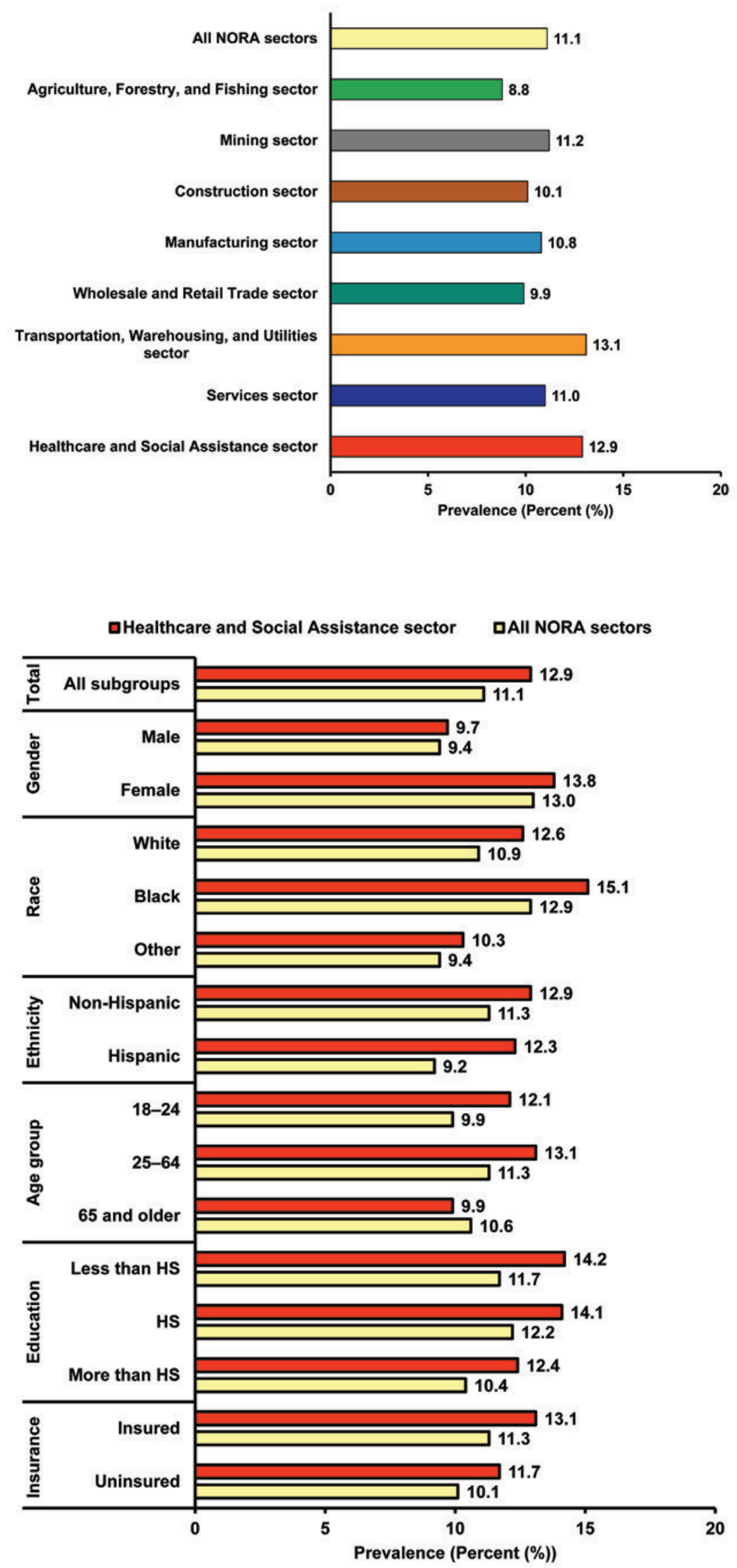
Prevalence of health problems requiring the use of special equipment estimated for workers 18 years and older
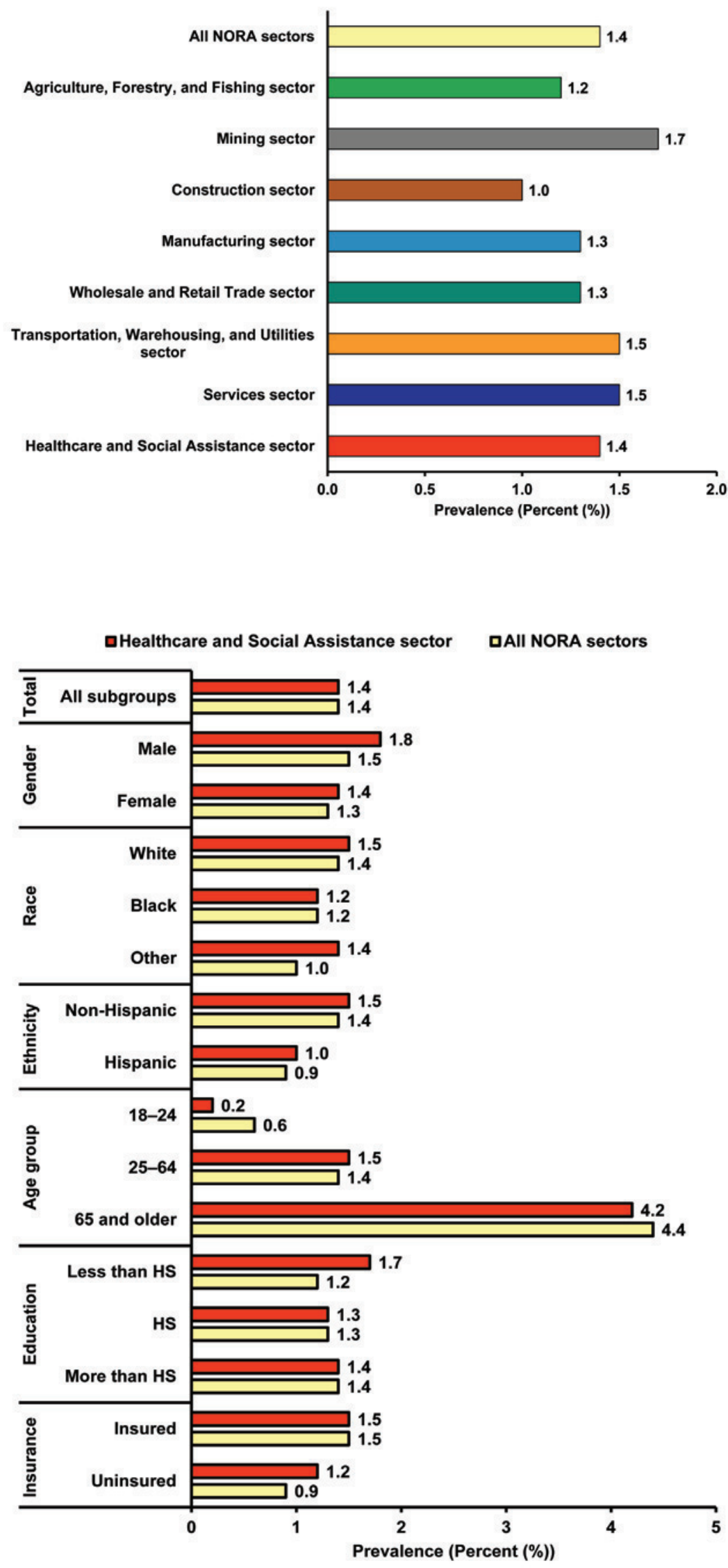

Figure 7a. Workers 18 years and older by NORA sectors, National Health Interview Survey, 1997-2007.

Health problems that require the use of special equipment (such as a cane, a wheelchair, or a special telephone) are uncommon in the U.S. workforce as a whole, with a prevalence of $1.4 \%$ among all employed workers (see Table 2, page 42, and Tables 15 and 16, pages 56-57)). Among the NORA sectors, Mining sector workers reported the highest prevalence of health problems requiring the use of special equipment (1.7\%), while Construction sector workers reported the lowest $(1.0 \%)$.

Figure 7b. Workers 18 years and older, Healthcare and Social Assistance sector and All NORA sectors, National Health Interview Survey, 1997-2007.

An estimated $1.4 \%$ of workers employed in the Healthcare and Social Assistance sector reported having a health problem that required the use of special equipment. Among the subgroups, workers 65 years of age or older reported the highest prevalence of health problems requiring the use of special equipment (4.2\%), while workers 18-24 years of age reported the lowest $(0.2 \%$ ) (see Table 16, page 57). Among all U.S. workers, workers 65 years of age or older reported the highest prevalence of health problems requiring the use of special equipment (4.4\%), while workers $18-24$ years of age reported the lowest $(0.6 \%)$ (see Table 15, page 56). 


\section{Prevalence of any functional limitations estimated for workers 18 years and older}

Figure 8a. Workers 18 years and older by NORA sectors, National Health Interview Survey, 1997-2007. An estimated $21.6 \%$ of all employed U.S. workers reported experiencing any functional limitations (see Table 2, page 42, and Tables 17 and 18, pages 58-59). Among the NORA sectors, Healthcare and Social Assistance sector workers reported the highest prevalence of experiencing any functional limitations (25.1\%), while Construction sector workers reported the lowest (17.8\%). These functional limitations include: having difficulty walking $1 / 4$ mile without special equipment, reaching over without special equipment, attending events without special equipment, etc.

Figure 8b. Workers 18 years and older, Healthcare and Social Assistance sector and All NORA sectors, National Health Interview Survey, 1997-2007.

An estimated $25.1 \%$ of workers employed in the Healthcare and Social Assistance sector reported experiencing any functional limitations. Among the subgroups, workers 65 years of age or older reported the highest prevalence of experiencing any functional limitations (46.4\%), while workers 18-24 years of age reported the lowest (13.7\%) (see Table 18, page 59). Among all U.S. workers, those 65 years of age or older reported the highest prevalence of experiencing any functional limitations (43.7\%), while workers 18-24 years of age reported the lowest (11.9\%) (see Table 17, page 58).
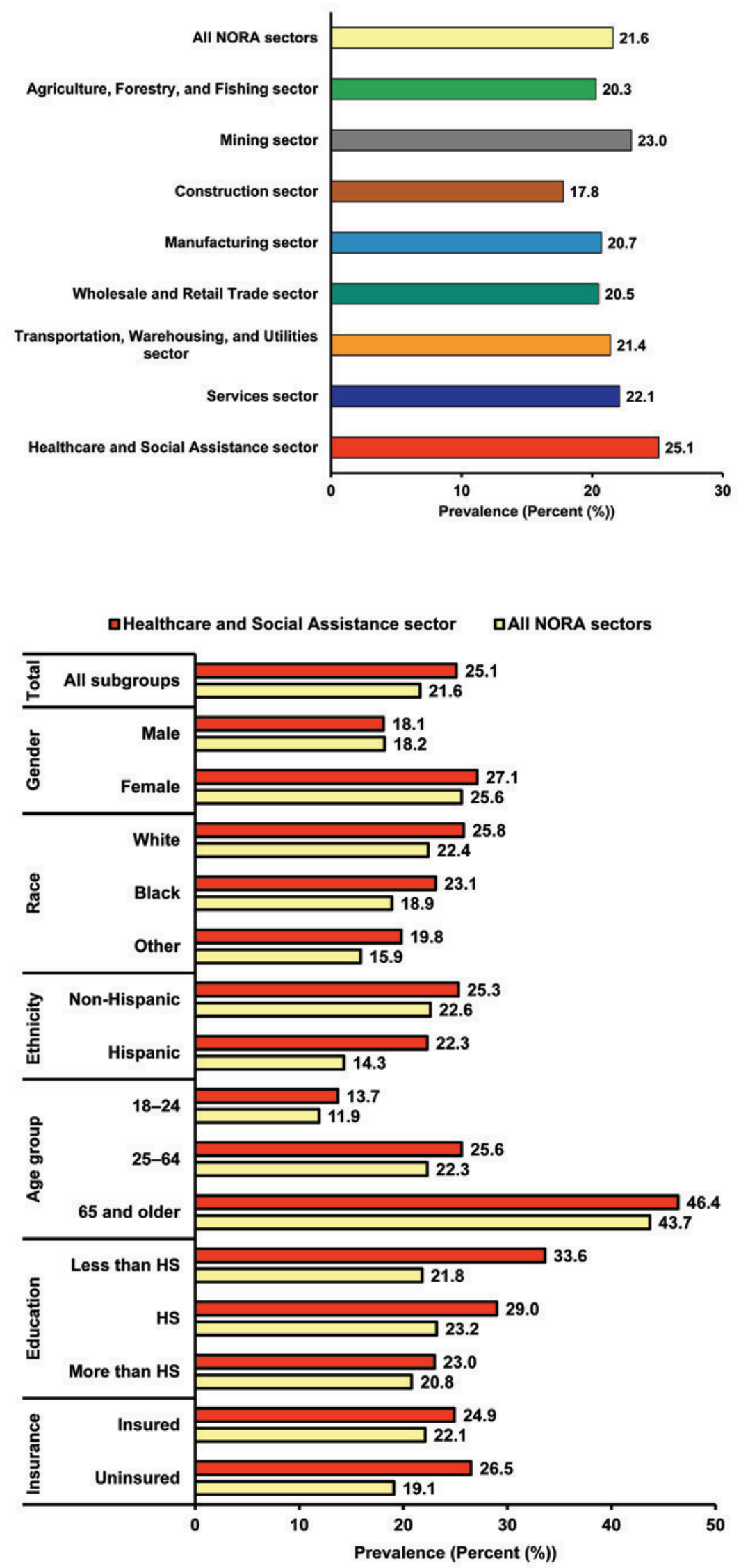


\section{Prevalence of hearing difficulty estimated for workers 18 years and older}

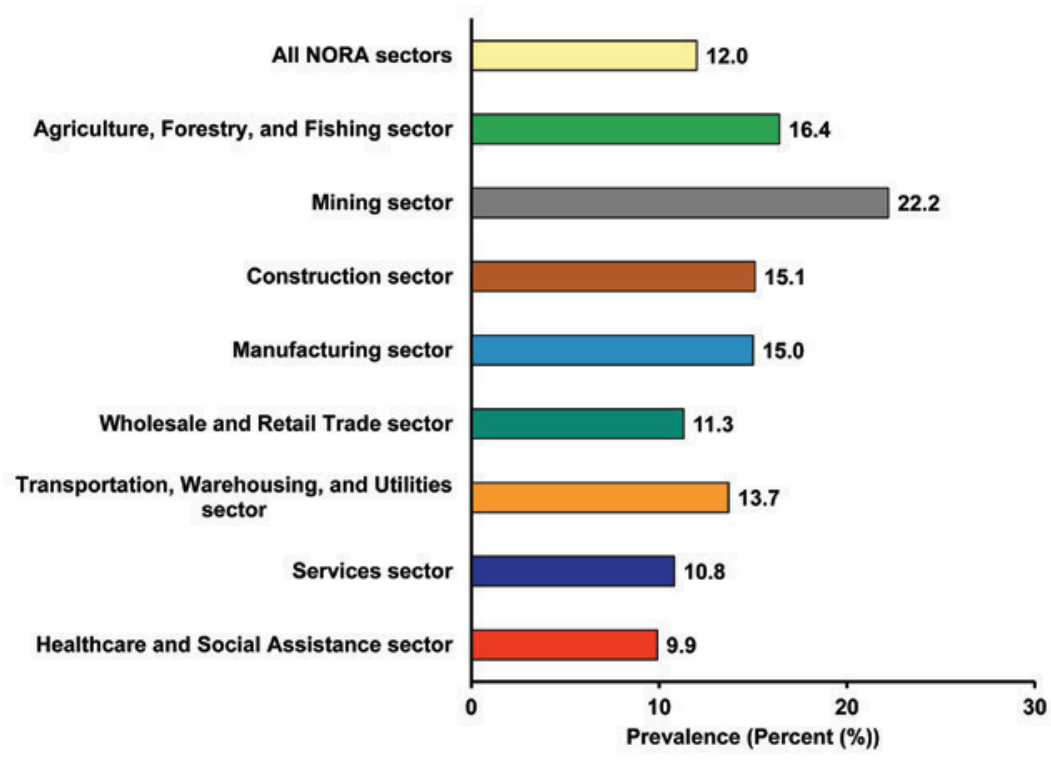

口Healthcare and Social Assistance sector

口All NORA sectors

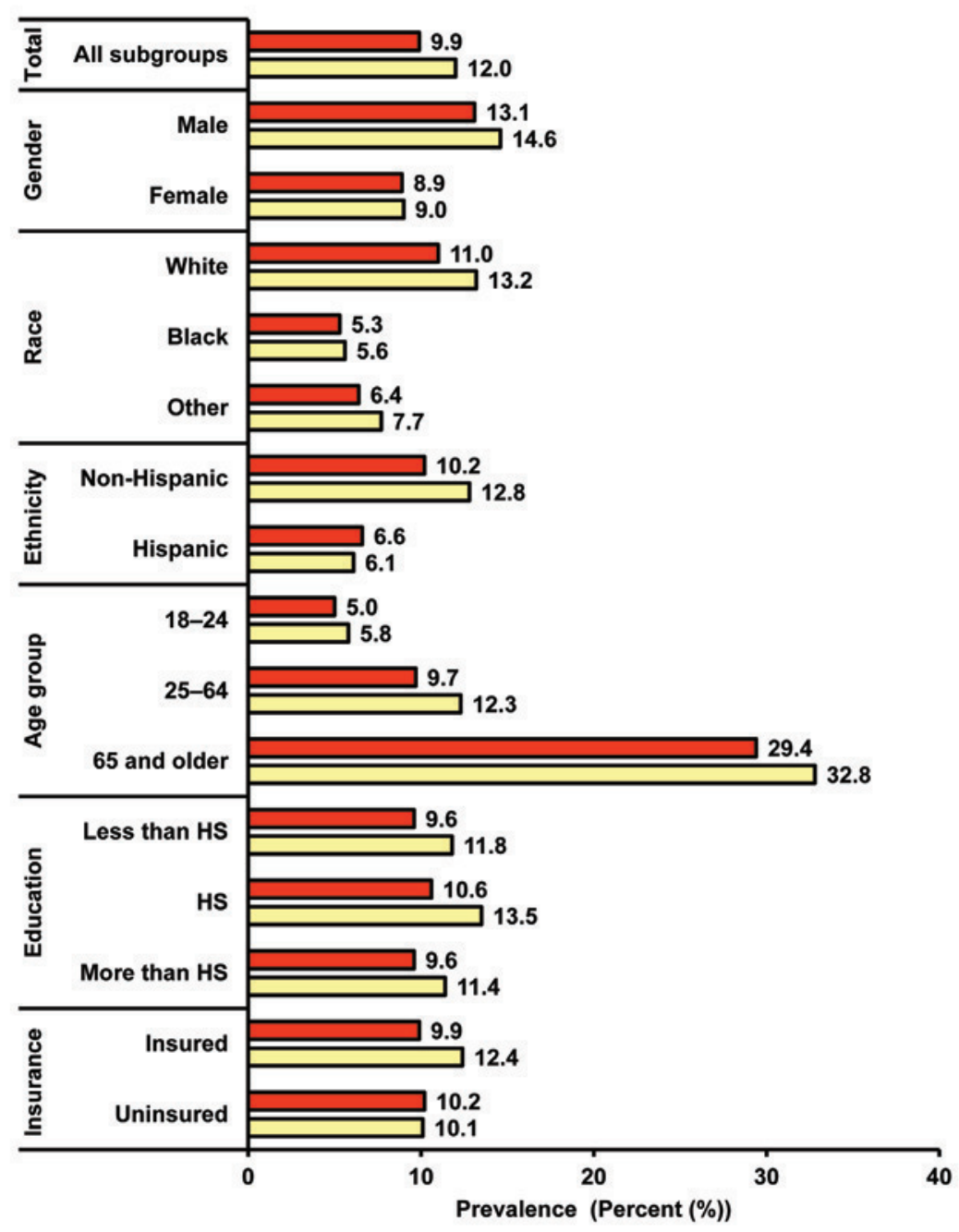

Figure 9a. Workers 18 years and older by NORA sectors, National Health Interview Survey, 1997-2007. An estimated $12.0 \%$ of all employed U.S. workers reported any hearing difficulty (see Table 2, page 42, and Tables 19 and 20, pages 60-61). There was more than a two-fold difference in prevalence of any reported hearing difficulty (defined as a little trouble, a lot of trouble, or deaf) across the NORA sectors. Mining sector workers reported markedly higher prevalence of hearing difficulty $(22.2 \%)$ relative to all other groups, while Healthcare and Social Assistance sector workers reported the lowest rate of hearing difficulty $(9.9 \%)$.

Figure 9b. Workers 18 years and older, Healthcare and Social Assistance sector and All NORA sectors, National Health Interview Survey, 1997-2007.

An estimated $9.9 \%$ of workers employed in the Healthcare and Social Assistance sector reported any hearing difficulty. Among the subgroups, workers 65 years of age or older reported the highest prevalence of any hearing difficulty $(29.4 \%)$, while workers 18-24 years of age reported the lowest (5.0\%) (see Table 20, page 61). Among all U.S. workers, those 65 years of age or older reported the highest prevalence of any hearing difficulty (32.8\%), while Black workers reported the lowest $(5.6 \%$ ) (see Table 19 , page 60). 


\section{Prevalence of visual impairment estimated for workers 18 years and older}

Figure 10a. Workers 18 years and older by NORA sectors, National Health Interview Survey, 1997-2007. An estimated $6.7 \%$ of all employed U.S. workers reported current visual impairment (see Table 2, page 42, and Tables 21 and 22, pages 62-63). Among the NORA sectors, Healthcare and Social Assistance sector workers reported the highest prevalence of current visual impairment (7.7\%), while Mining sector workers reported the lowest (4.7\%).

Figure 10b. Workers 18 years and older, Healthcare and Social Assistance sector and All NORA sectors, National Health Interview Survey, 1997-2007.

An estimated $7.7 \%$ of workers employed in the Healthcare and Social Assistance sector reported current visual impairment. Among the subgroups, uninsured workers reported the highest prevalence of current visual impairment (11.2\%), while workers of "Other" race reported the lowest (5.2\%) (see Table 22, page 63). Among all U.S. workers, those 65 years of age or older reported the highest prevalence of current visual impairment (10.0\%), while workers 18-24 years of age reported the lowest $(5.0 \%)$. Female workers also reported higher rates of current visual impairment relative to men $(8.0 \%$ vs. $5.5 \%)$ (see Table 21, page 62).
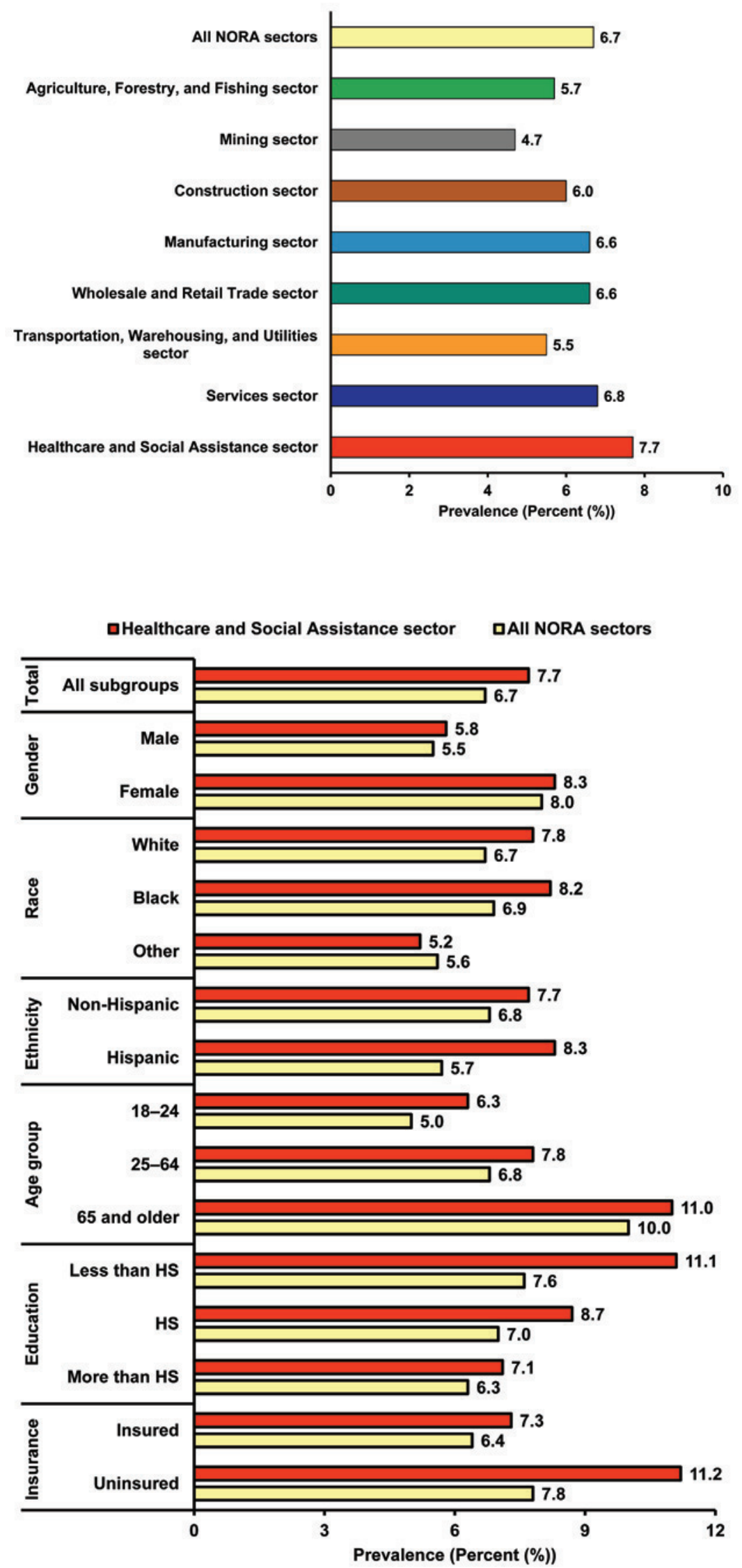


\section{Prevalence of cancer estimated for workers 18 years and older}

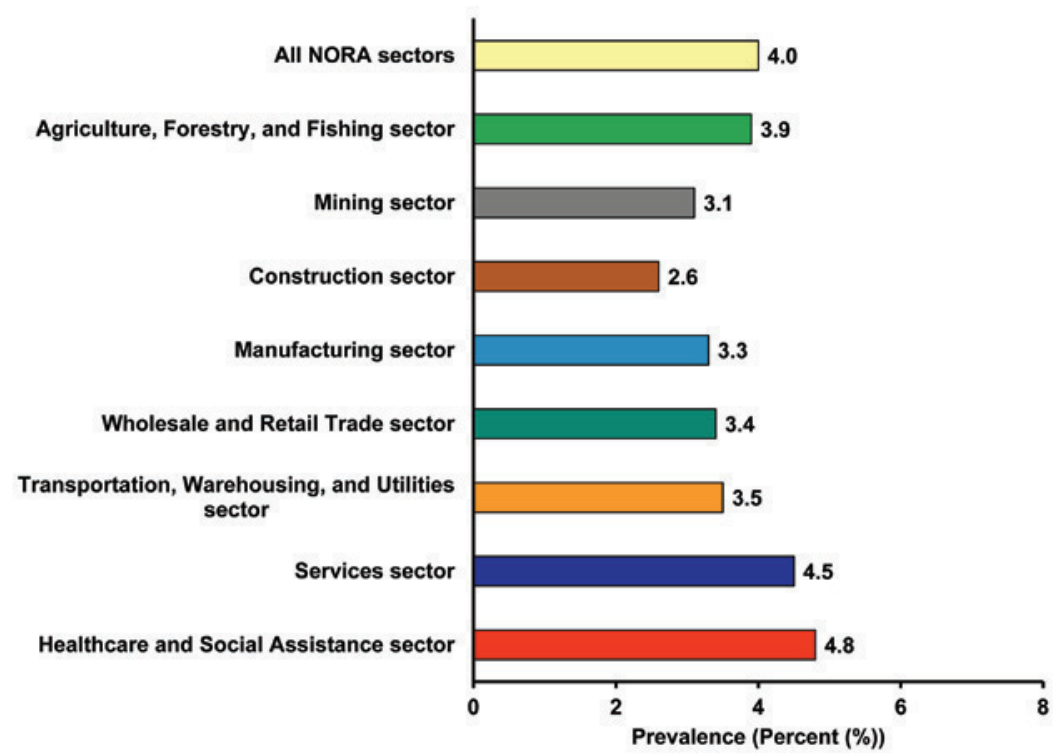

口Healthcare and Social Assistance sector

口All NORA sectors

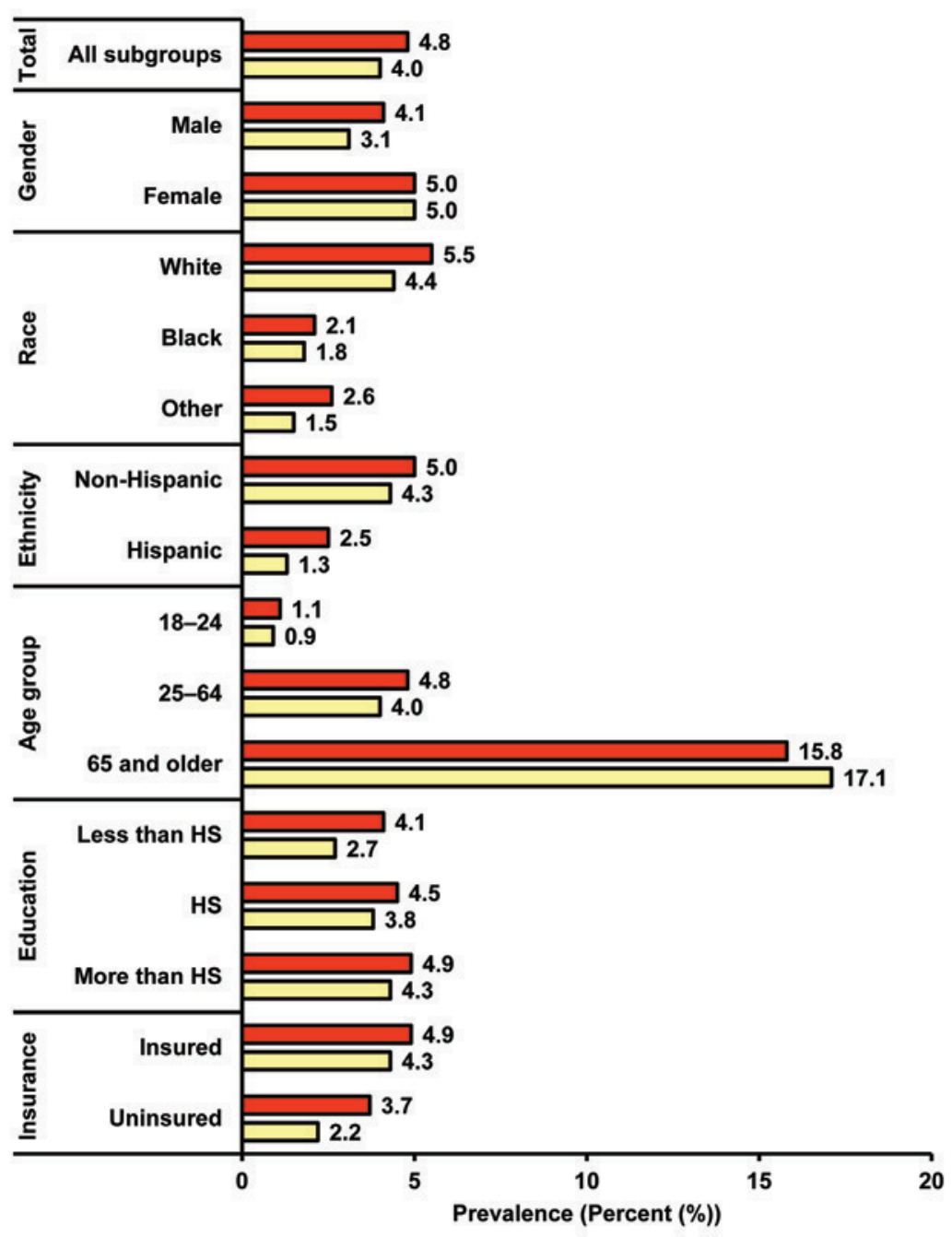

Figure 11a. Workers 18 years and older by NORA sectors, National Health Interview Survey, 1997-2007. An estimated $4.0 \%$ of all employed U.S. workers reported ever having a diagnosis of cancer (see Table 2, page 42, and Tables 23 and 24, pages 64-65). Among the NORA sectors, Healthcare and Social Assistance sector workers reported the highest prevalence of ever having a diagnosis of cancer $(4.8 \%)$, while Construction sector workers reported the lowest $(2.6 \%)$.

Figure 11b. Workers 18 years and older, Healthcare and Social Assistance sector and All NORA sectors, National Health Interview Survey, 1997-2007.

An estimated $4.8 \%$ of workers employed in the Healthcare and Social Assistance sector reported ever having a diagnosis of cancer. Among the subgroups, workers 65 years of age or older reported the highest prevalence of ever having a diagnosis of cancer (15.8\%), while workers 18-24 years of age reported the lowest (1.1\%) (see Table 24, page 65). Among all U.S. workers, those 65 years of age or older reported the highest prevalence of ever having a diagnosis of cancer (17.1\%), while workers 18-24 years of age reported the lowest $(0.9 \%)$. Hispanics reported much lower cancer rates relative to Non-Hispanics (1.3\% vs. $4.3 \%$ ), while Whites reported higher rates relative to Blacks (4.4\% vs. $1.8 \%$ ) (see Table 23, page 64). 


\section{Prevalence of hypertension estimated for workers 18 years and older}

Figure 12a. Workers 18 years and older by NORA sectors, National Health Interview Survey, 1997-2007. An estimated $17.7 \%$ of all employed U.S. workers reported ever having a diagnosis of hypertension (see Table 2, page 42, and Tables 25 and 26, pages 66-67). Among the NORA sectors, Mining sector workers reported the highest prevalence of ever having a diagnosis of hypertension (23.2\%), while Construction sector workers reported the lowest (15.1\%).

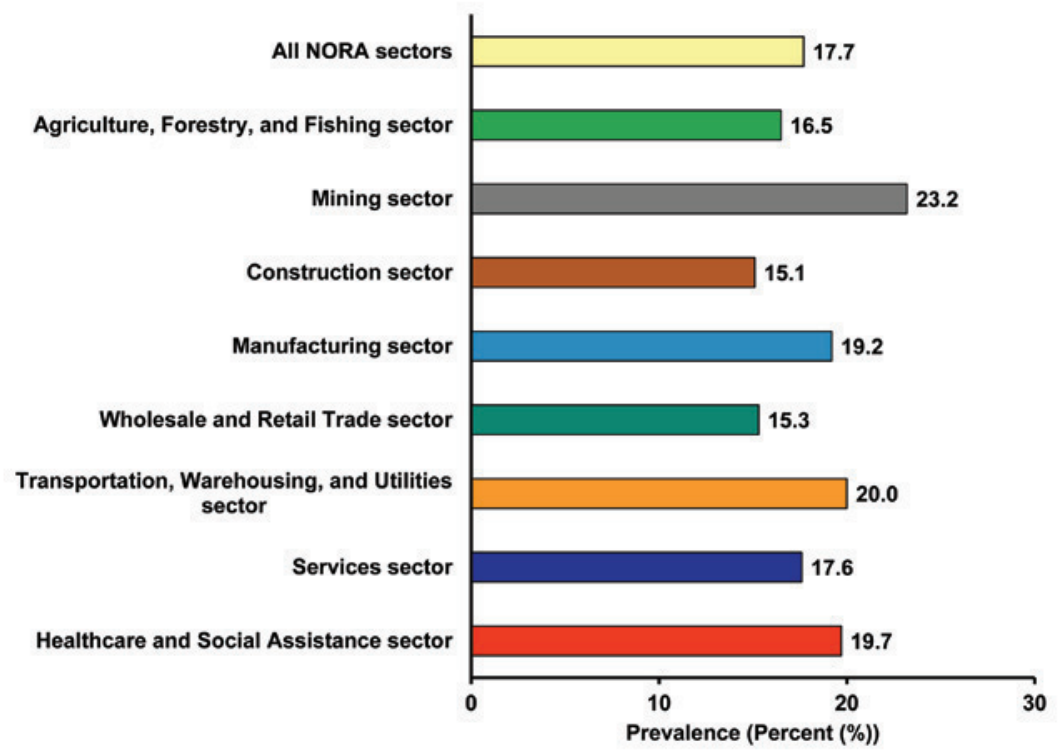

Figure 12b. Workers 18 years and older, Healthcare and Social Assistance sector and All NORA sectors, National Health Interview Survey, 1997-2007.

An estimated $19.7 \%$ of workers employed in the Healthcare and Social Assistance sector reported ever having a diagnosis of hypertension. Among the subgroups, workers 65 years of age or older reported the highest prevalence of ever having a diagnosis of hypertension (48.8\%), while workers 18-24 years of age reported the lowest (5.3\%) (see Table 26, page 67). Among all U.S. workers, those 65 years of age or older reported the highest prevalence of ever having a diagnosis of hypertension (47.5\%), while workers 18-24 years of age reported the lowest $(4.6 \%)$ (see Table 25 , page 66).

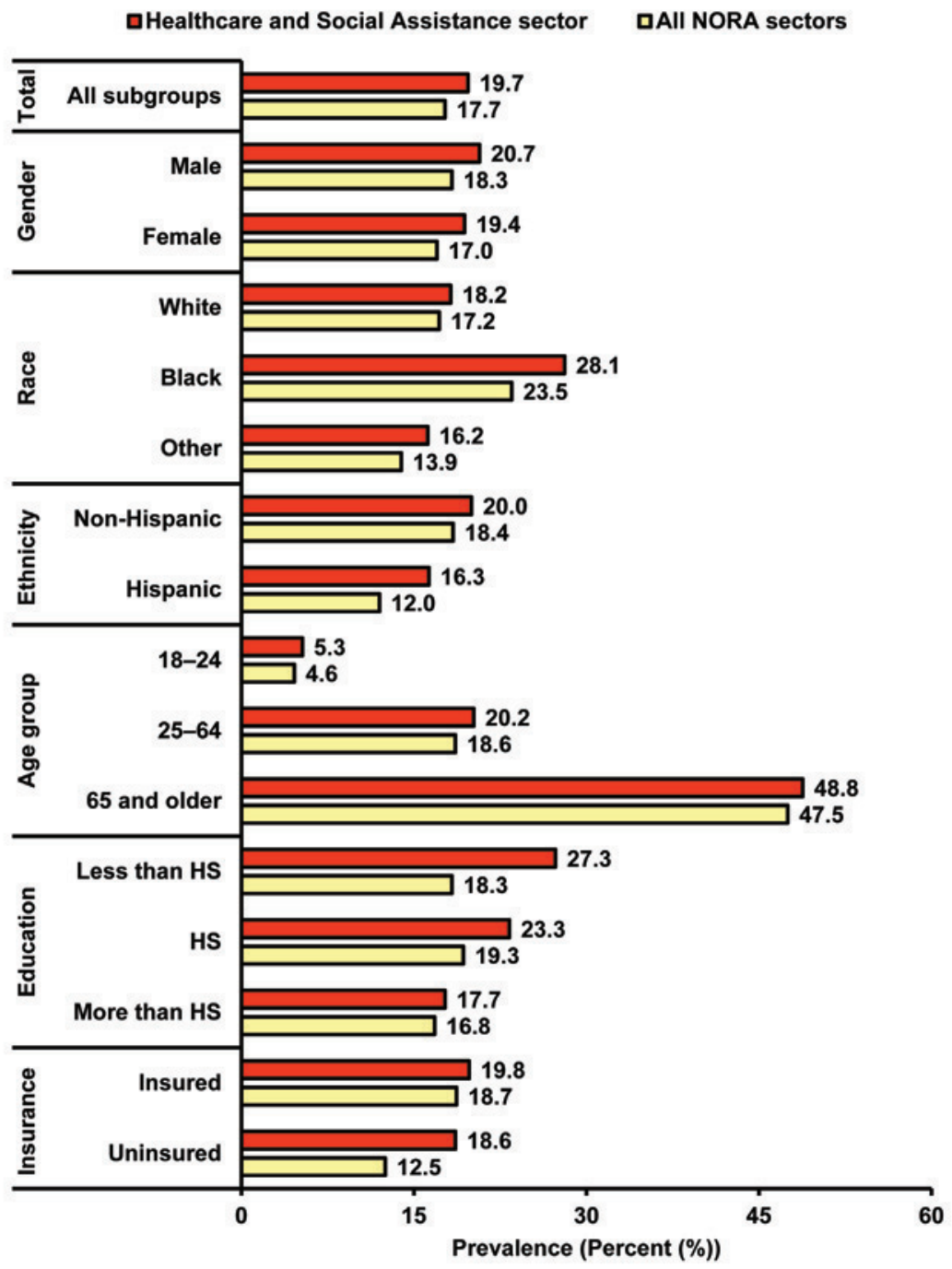




\section{Prevalence of heart disease estimated for workers 18 years and older}

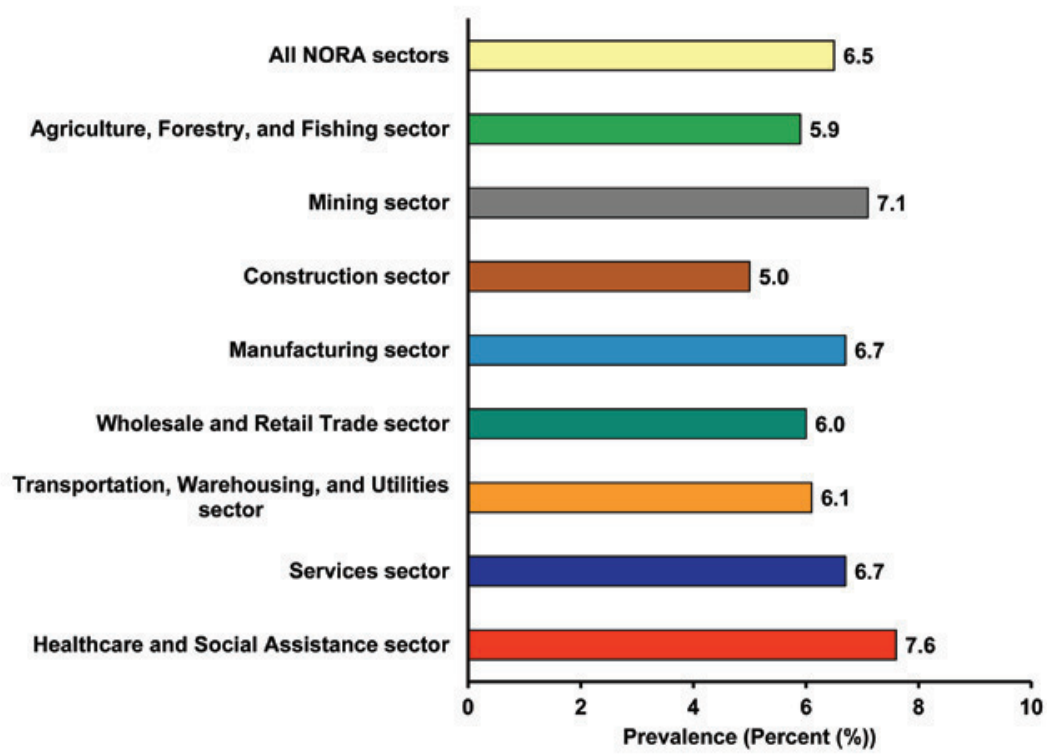

口Healthcare and Social Assistance sector

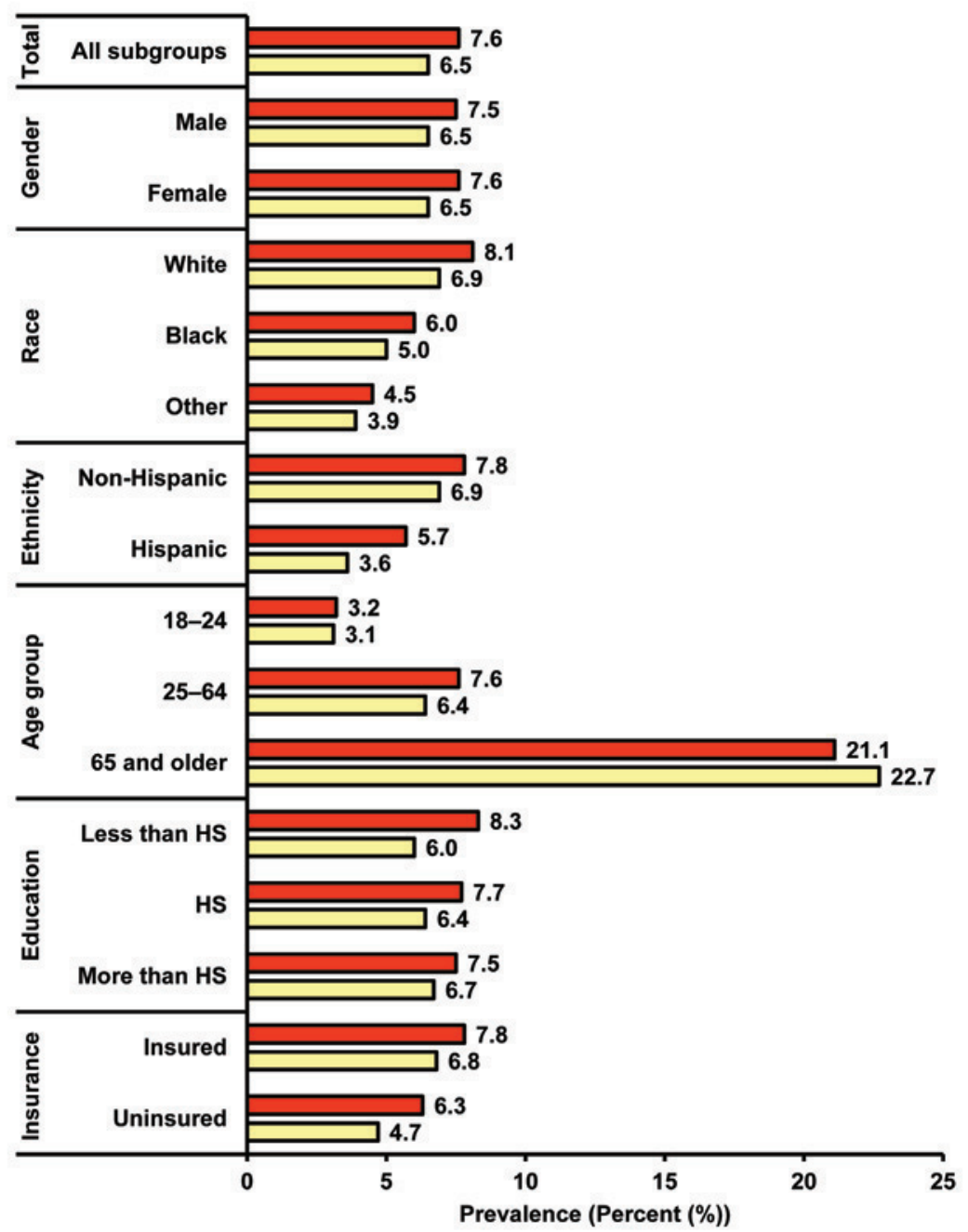

Figure 13a. Workers 18 years and older by NORA sectors, National Health Interview Survey, 1997-2007. An estimated $6.5 \%$ of all employed U.S. workers reported ever having a diagnosis of heart disease (see Table 2, page 42 and Tables 27 and 28, pages 68-69). Among the NORA sectors, Healthcare and Social Assistance sector workers reported the highest prevalence of ever having a diagnosis of heart disease (7.6\%), while Construction sector workers reported the lowest (5.0\%).

Figure 13b. Workers 18 years and older, Healthcare and Social Assistance sector and All NORA sectors, National Health Interview Survey, 1997-2007.

An estimated $7.6 \%$ of workers employed in the Healthcare and Social Assistance sector reported ever having a diagnosis of heart disease. Among the subgroups, workers 65 years of age or older reported the highest prevalence of ever having a diagnosis of heart disease $(21.1 \%)$, while workers 18-24 years of age reported the lowest (3.2\%) (see Table 28, page 69). Among all U.S. workers, those 65 years of age or older reported the highest prevalence of ever having a diagnosis of heart disease $(22.7 \%)$, while workers 18-24 years of age reported the lowest (3.1\%). Men and women reported the same rates of heart disease (6.5\%) (see Table 27, page 68). 


\section{Prevalence of asthma estimated for workers 18 years}

Figure 14a. Workers 18 years and older by NORA sectors National Health Interview Survey, 1997-2007. An estimated $9.4 \%$ of all employed U.S. workers reported ever having a diagnosis of asthma (see Table 2, page 42, and Tables 29 and 30, pages 70-71). Among the NORA sectors, Healthcare and Social Assistance sector workers reported the highest prevalence of ever having a diagnosis of asthma (11.0\%), while Agriculture, Forestry and Fishing sector workers reported the lowest $(6.5 \%)$.

Figure 14b. Workers 18 years and older, Healthcare and Social Assistance sector and All NORA sectors National Health Interview Survey, 1997-2007.

An estimated $11.0 \%$ of workers employed in the Healthcare and Social Assistance sector reported ever having a diagnosis of asthma. Among the subgroups, workers 18-24 years of age reported the highest prevalence of ever having a diagnosis of asthma (15.4\%), while workers 65 years of age or older reported the lowest (7.6\%) (see Table 30, page 71). Among all U.S. workers, those 18-24 years of age reported the highest prevalence of ever having a diagnosis of asthma (13.1\%), while Hispanic workers reported the lowest (6.9\%) (see Table 29, page 70).
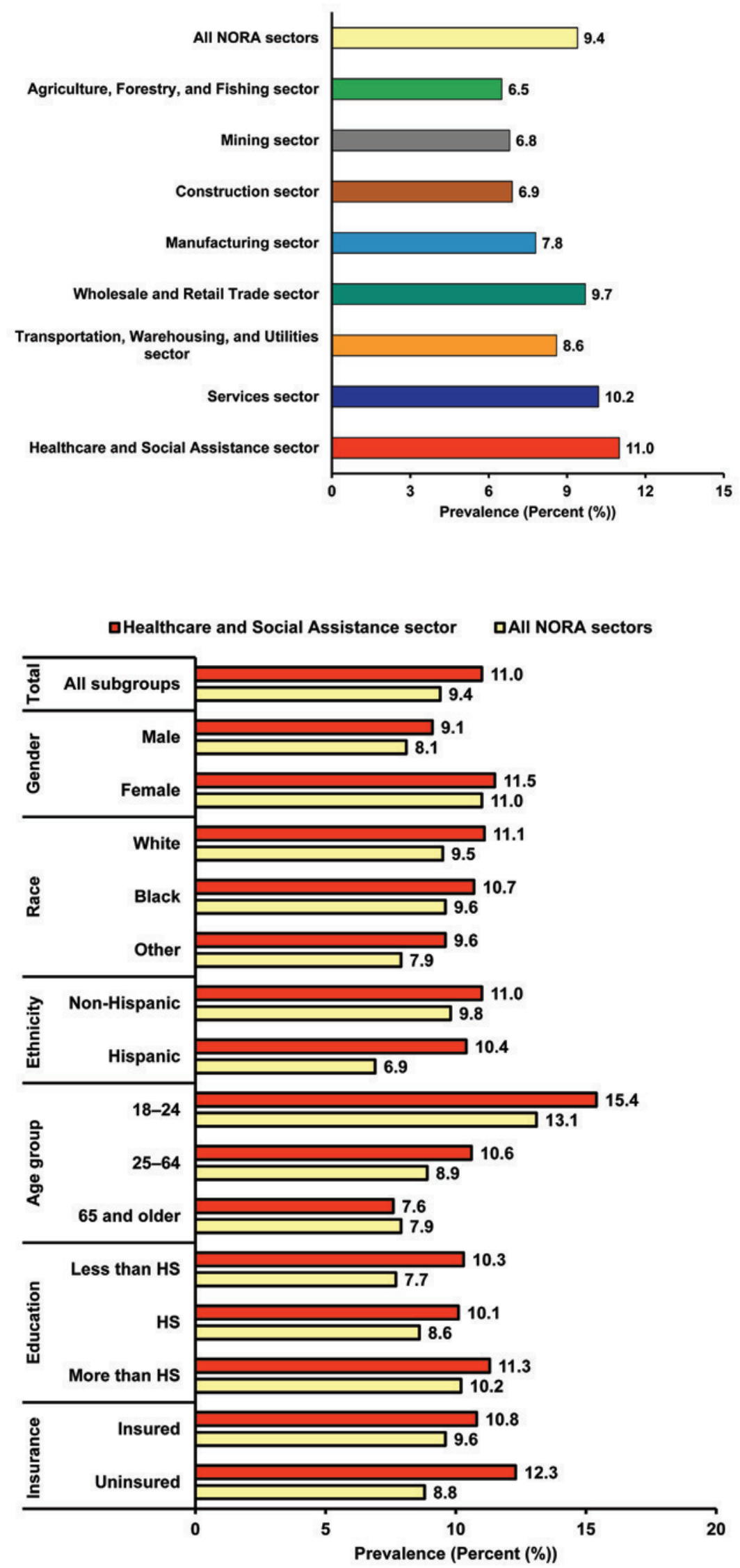


\section{Prevalence of diabetes estimated for workers 18 years and older}
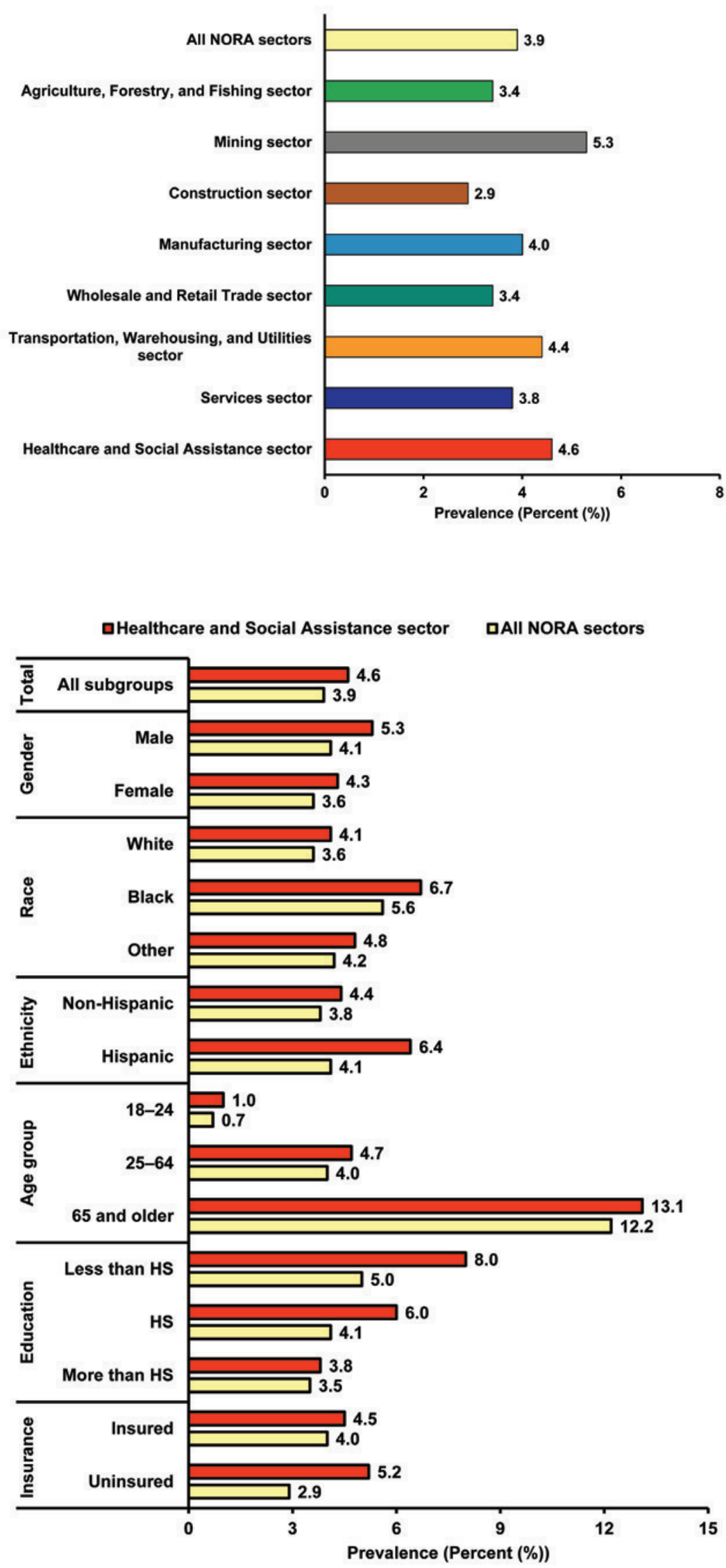

Figure 15a. Workers 18 years and older by NORA sectors, National Health Interview Survey, 1997-2007. An estimated $3.9 \%$ of all employed U.S. workers reported ever having a diagnosis of diabetes (see Table 2, page 42, and Tables 31 and 32, pages 72-73). Among the NORA sectors, Mining sector workers reported the highest prevalence of ever having a diagnosis of diabetes $(5.3 \%)$, while Construction sector workers reported the lowest $(2.9 \%)$.

Figure 15b. Workers 18 years and older, Healthcare and Social Assistance sector and All NORA sectors, National Health Interview Survey, 1997-2007.

An estimated $4.6 \%$ of workers employed in the Healthcare and Social Assistance sector reported ever having a diagnosis of diabetes. Among the subgroups, workers 65 years of age or older reported the highest prevalence of ever having a diagnosis of diabetes (13.1\%), while workers 18-24 years of age reported the lowest $(1.0 \%)$ (see Table 32, page 73). Among all U.S. workers, those 65 years of age or older reported the highest prevalence of ever having a diagnosis of diabetes $(12.2 \%)$, while workers $18-24$ years of age reported the lowest $(0.7 \%)$. Black workers reported higher rates of diabetes relative to White workers $(5.6 \%$ vs. $3.6 \%$ ) (see Table 31, page 72). 


\section{Prevalence of severe psychological distress estimated for workers 18 years and older}

Figure 16a. Workers 18 years and older by NORA sectors, National Health Interview Survey, 1997-2007. An estimated $0.5 \%$ of all employed U.S. workers reported ever having a diagnosis of severe psychological distress (see Table 2, page 42, and Tables 33 and 34, pages 74-75). Among the NORA sectors, Wholesale and Retail Trade sector workers and Mining sector workers reported the highest prevalence of ever having a diagnosis of severe psychological distress $(0.7 \%)$, while Services sector workers reported the lowest $(0.4 \%)$.

Figure 16b. Workers 18 years and older, Healthcare and Social Assistance sector and All NORA sectors, National Health Interview Survey, 1997-2007.

An estimated $0.6 \%$ of workers employed in the Healthcare and Social Assistance sector reported ever having a diagnosis of severe psychological distress. Among the subgroups, workers with less than a high school education reported the highest prevalence of ever having a diagnosis of severe psychological distress (1.8\%), while workers 65 years and older reported the lowest $(0.0 \%)$. Of note, the sample response cell size for these workers was 1 , and the estimated prevalence was greater than 0.0 but less 0.05 (see Table 34, page 75). Among all U.S workers, those with less than a high school education (1.2\%) and uninsured workers $(1.0 \%)$ reported the highest prevalence of ever having a diagnosis of severe psychological distress, with all other subgroups reporting rates below $1 \%$ (see Table 33 , page 74 ).
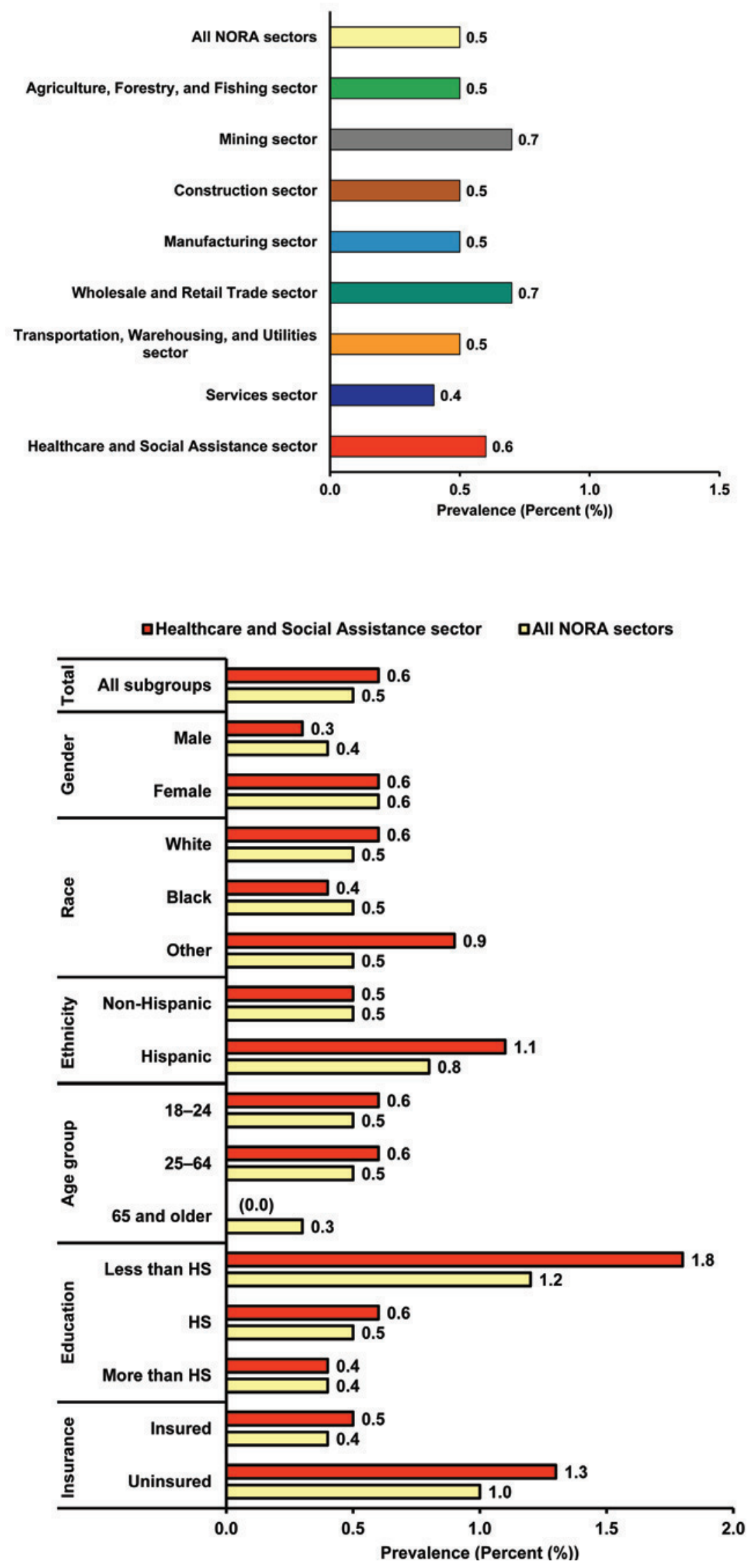


\section{Prevalence of not having seen a primary health care provider during the past 12 months estimated} for workers 18 years and older

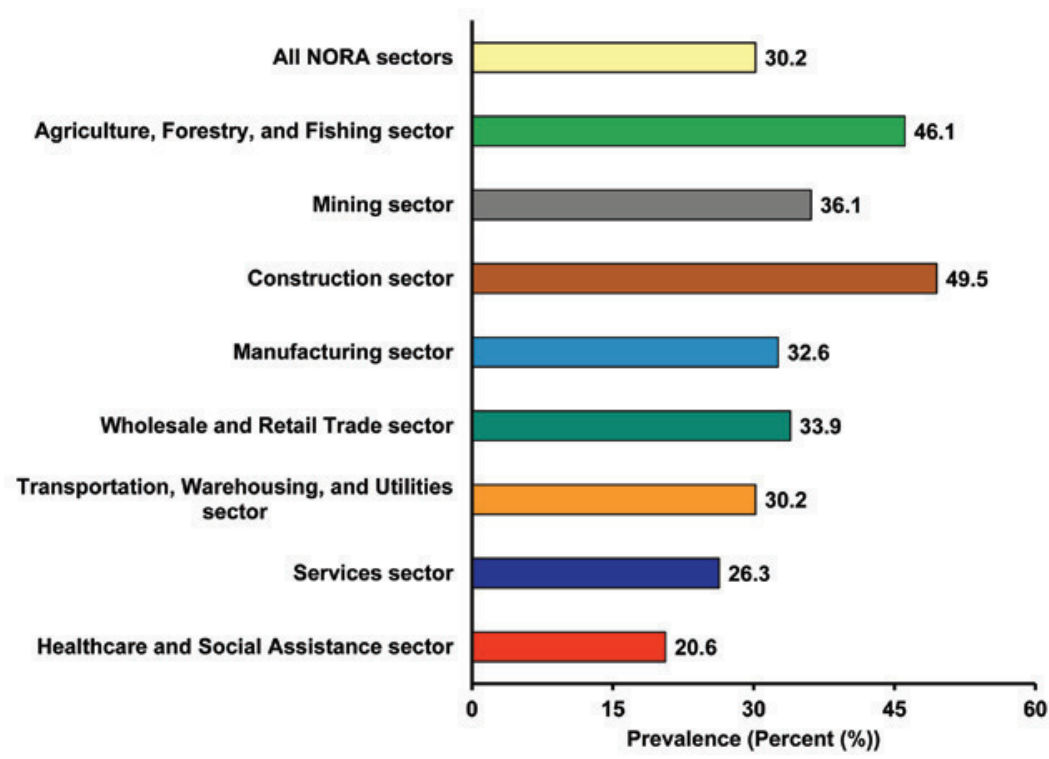

口Healthcare and Social Assistance sector

口All NORA sectors

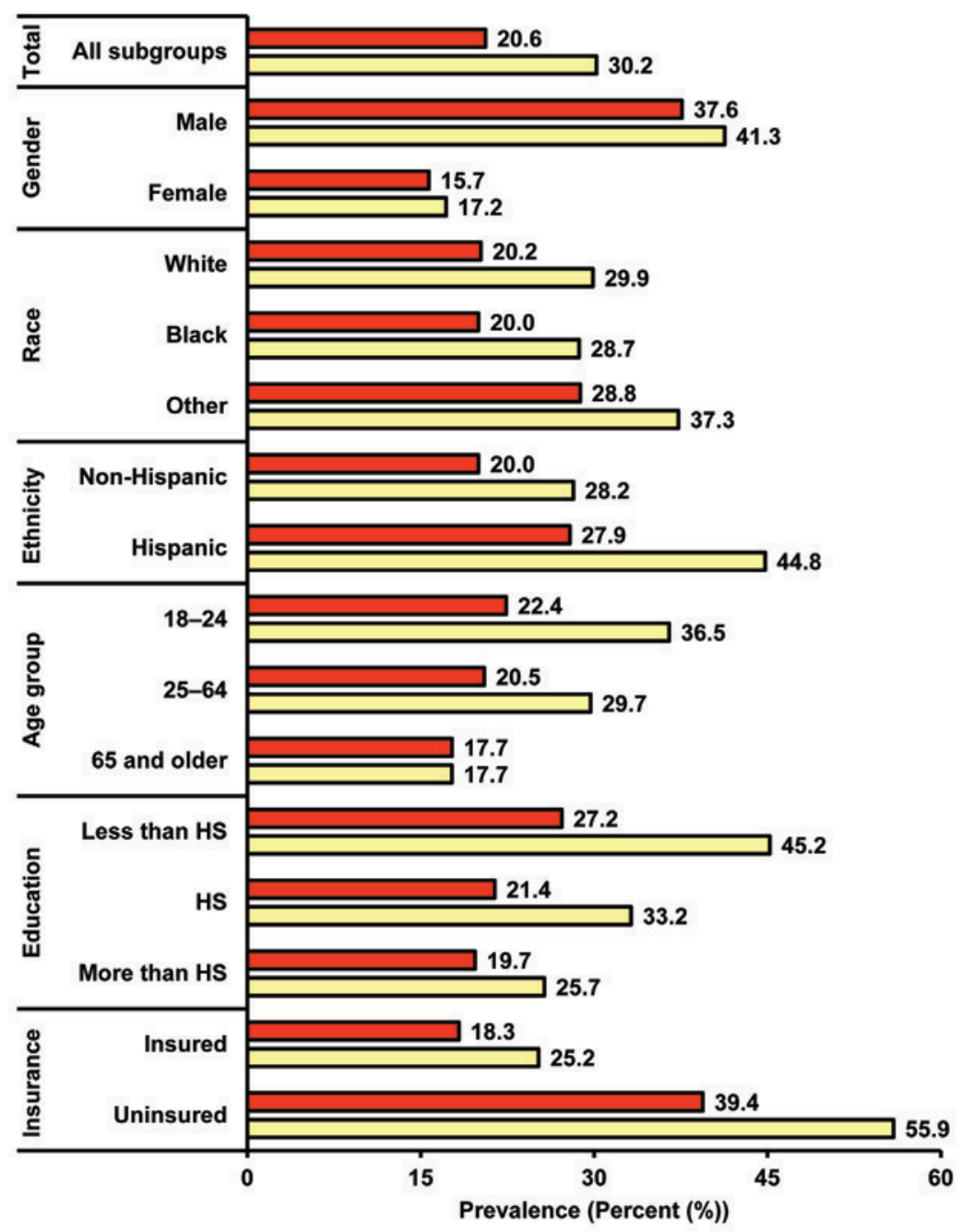

Figure 17a. Workers 18 years and older by NORA sectors, National Health Interview Survey, 1997-2007. An estimated $30.2 \%$ of all employed U.S. workers reported not having seen a primary health care provider during the past 12 months (see Table 2, page 42, and Tables 35 and 36, pages 76-77). Among the NORA sectors, Construction sector workers reported the highest prevalence of not having seen a primary health care provider during the past 12 months (49.5\%), while Healthcare and Social Assistance sector workers reported the lowest (20.6\%).

Figure 17b. Workers 18 years and older, Healthcare and Social Assistance sector and All NORA sectors, National Health Interview Survey, 1997-2007.

An estimated $20.6 \%$ of workers employed in the Healthcare and Social Assistance sector reported not having seen a primary health care provider during the past 12 months. Among the subgroups, uninsured workers reported the highest prevalence of not having seen a primary health care provider during the past 12 months (39.4\%), while female workers reported the lowest (15.7\%) (see Table 36, page 77). Among all U.S. workers, uninsured workers reported the highest prevalence of not having seen a primary health care provider during the past 12 months $(55.9 \%)$, while female workers reported the lowest (17.2\%). Male workers were more than twice as likely to report not having seen a primary care provider during the past 12 months when compared to female workers (41.3\% vs. $17.2 \%$ ) (see Table 35 , page 76$)$. 


\section{Prevalence of dentist contact of 1 year or greater estimated for workers 18 years and older}

Figure 18a. Workers 18 years and older by NORA sectors, National Health Interview Survey, 1997-2007. An estimated $34.2 \%$ of all employed U.S. workers reported not having seen a dentist during the past year (see Table 2 , page 42 , and Tables 37 and 38 , pages 78-79). Among the NORA sectors, Agriculture, Forestry, and Fishing sector workers reported the highest prevalence of not having seen a dentist during the past year $(50.3 \%)$, while Healthcare and Social Assistance sector workers reported the lowest (27.9\%).

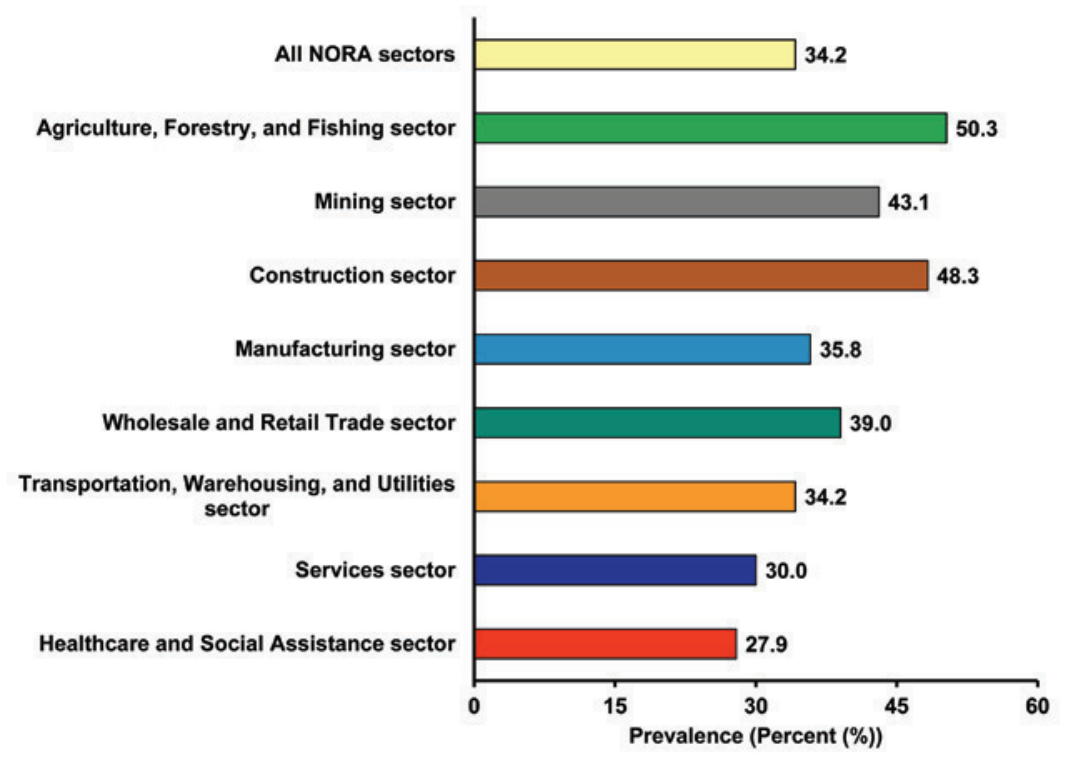

Figure 18b. Workers 18 years and older, Healthcare and Social Assistance sector and All NORA sectors, National Health Interview Survey, 1997-2007.

An estimated $27.9 \%$ of workers employed in the Healthcare and Social Assistance sector reported not having seen a dentist during the past year. Among the subgroups, uninsured workers reported the highest prevalence of not having seen a dentist during the past year (57.2\%), while workers with more than a high school education reported the lowest $(23.0 \%$ ) (see Table 38 , page 79). Among all U.S. workers, uninsured workers reported the highest prevalence of not having seen a dentist during the past year (63.5\%), while workers with more than a high school education reported the lowest (26.3\%). Workers with less than a high school education were more than twice as likely to report not having seen a dentist during the past year when compared to workers with more than a high school education (57.1\% vs. $26.3 \%$ ) (see Table 37 , page 78$)$.

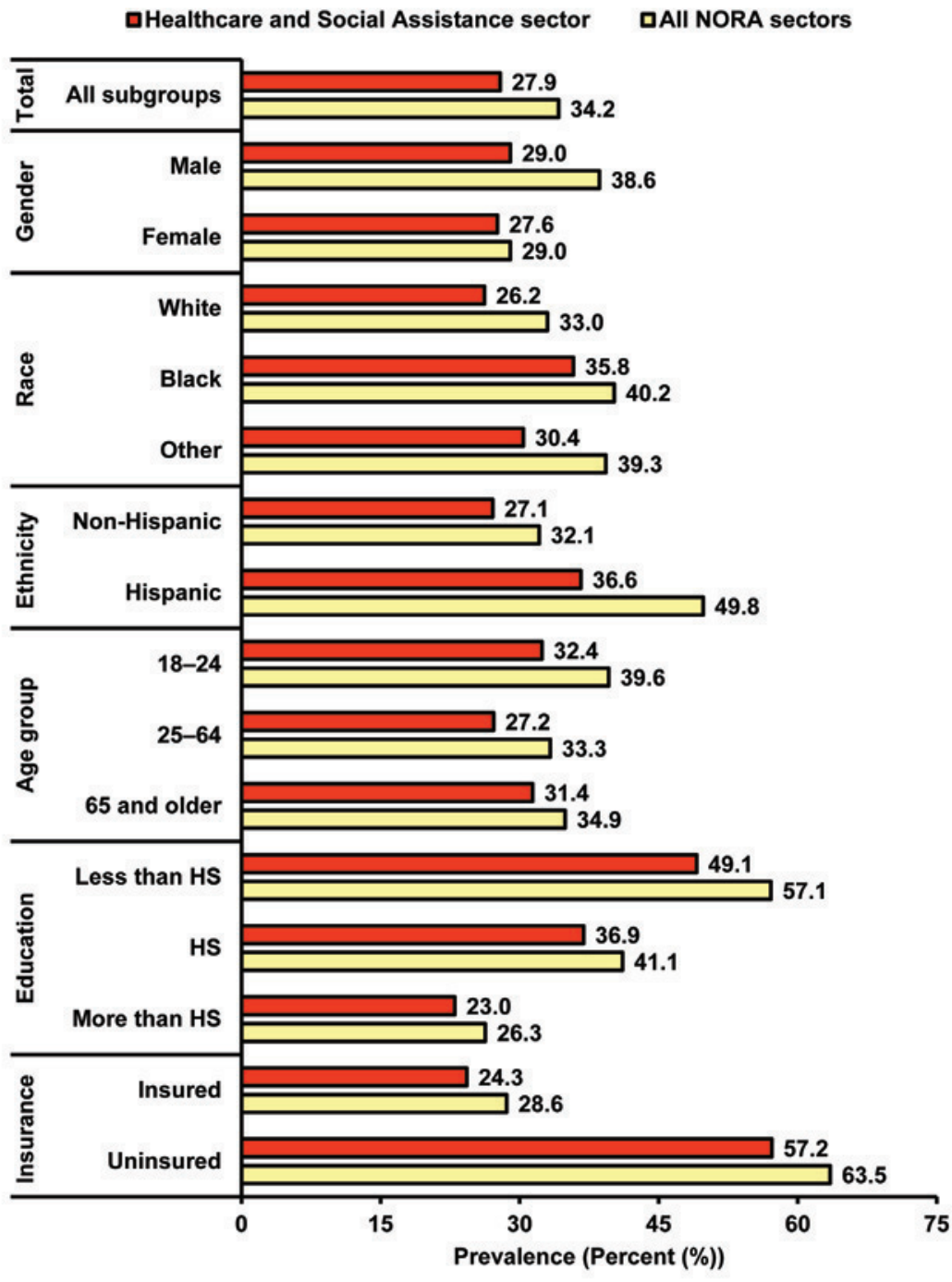




\section{Prevalence of surgery during the past 12 months estimated for workers 18 years and older}
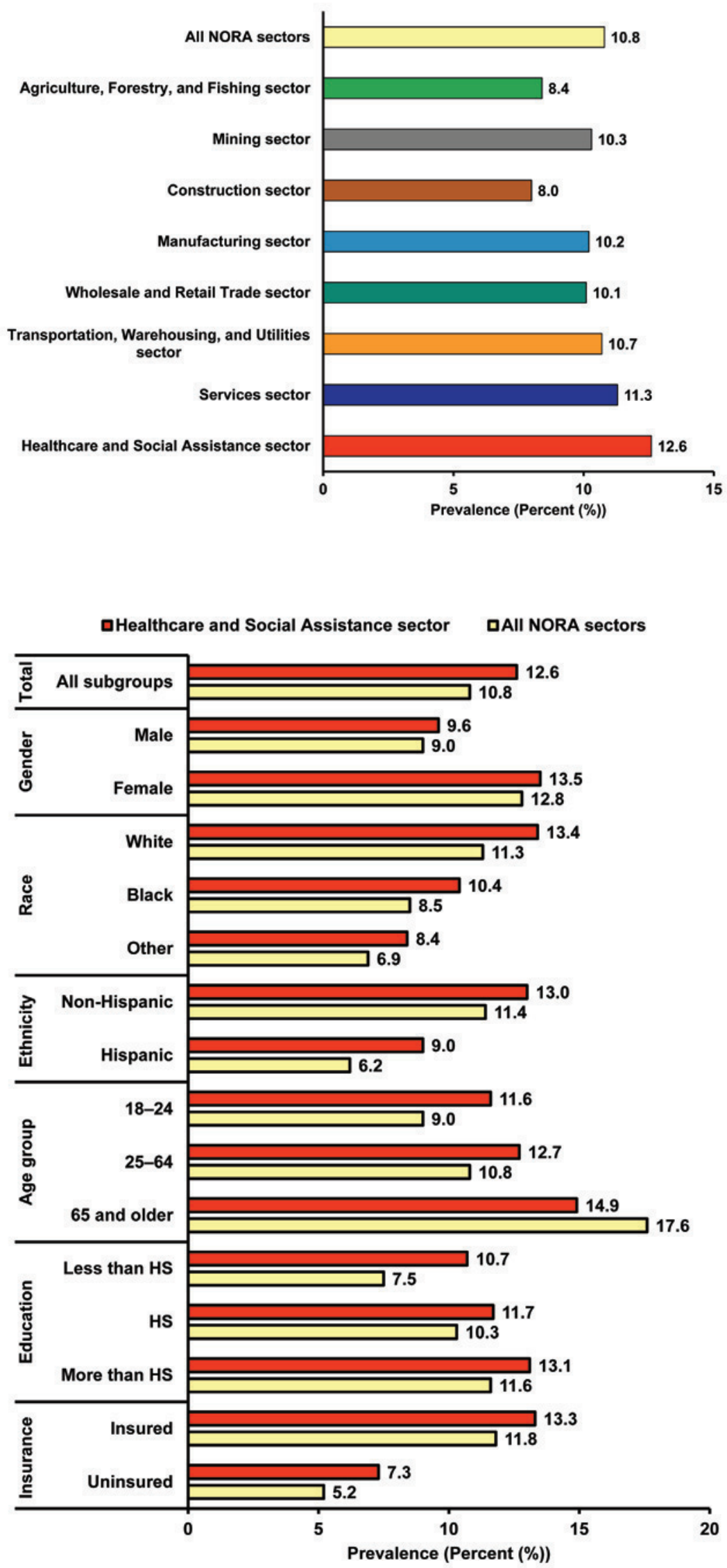

Figure 19a. Workers 18 years and older by NORA sectors, National Health Interview Survey, 19997-2007. An estimated 10.8\% of all employed U.S. workers reported having surgery during the past 12 months (see Table 2, page 42, and Tables 39 and 40, pages 80-81). Among the NORA sectors, Healthcare and Social Assistance sector workers reported the highest prevalence of having surgery during the past 12 months $(12.6 \%)$, while Construction sector workers reported the lowest $(8.0 \%)$.

Figure 19b. Workers 18 years and older, Healthcare and Social Assistance sector and All NORA sectors, National Health Interview Survey, 19997-2007.

An estimated $12.6 \%$ of workers employed in the Healthcare and Social Assistance sector reported having surgery during the past 12 months. Among the subgroups, workers 65 years of age or older reported the highest prevalence of having surgery during the past 12 months (14.9\%), while uninsured workers reported the lowest (7.3\%) (see Table 40, page 81). Among all U.S. workers, those 65 years of age or older reported the highest prevalence of having surgery during the past 12 months $(17.6 \%)$, while uninsured workers reported the lowest (5.2\%) (see Table 39, page 80). 


\section{Prevalence of hospital emergency room visit during the past 12 months estimated for workers 18 years and older}

Figure 20a. Workers 18 years and older by NORA sectors, National Health Interview Survey, 1997-2007. An estimated $17.6 \%$ of all employed U.S. workers reported at least one hospital emergency room visit during the past 12 months (see Table 2, page 42, and Tables 41 and 42, pages 82-83). Among the NORA sectors, Wholesale and Retail Trade sector workers reported the highest prevalence of at least one hospital emergency room visit during the past 12 months (19.1\%), while Agriculture, Forestry, and Fishing sector workers reported the lowest $(14.6 \%)$.

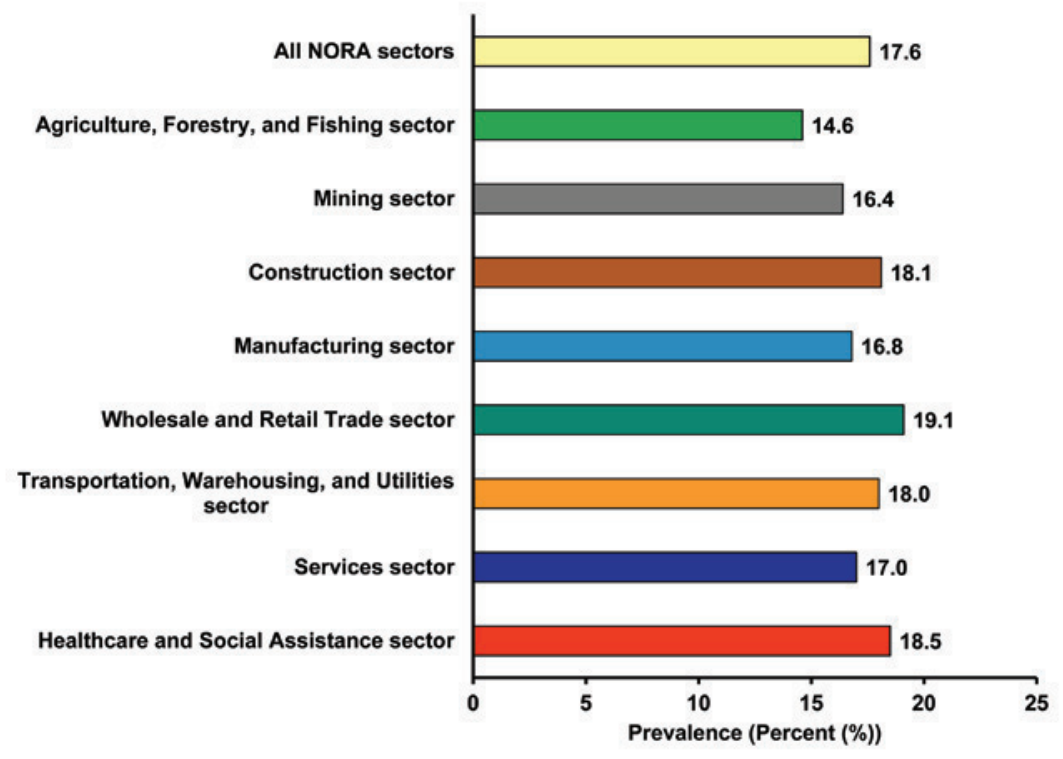

Figure 20b. Workers 18 years and older, Healthcare and Social Assistance sector and All NORA sectors, National Health Interview Survey, 1997-2007.

An estimated $18.5 \%$ of workers employed in the Healthcare and Social Assistance sector reported at least one hospital emergency room visit during the past 12 months. Among the subgroups, workers 18-24 years of age reported the highest prevalence of at least one hospital emergency room visit during the past 12 months (26.1\%), while workers of "Other" race and male workers reported the lowest (15.7\%) (see Table 42, page 83). Among all U.S. workers, those 18-24 years of age reported the highest prevalence of at least one hospital emergency room visit during the past 12 months $(24.2 \%)$, while workers of "Other" race reported the lowest (14.5\%) (see Table 41, page 82).

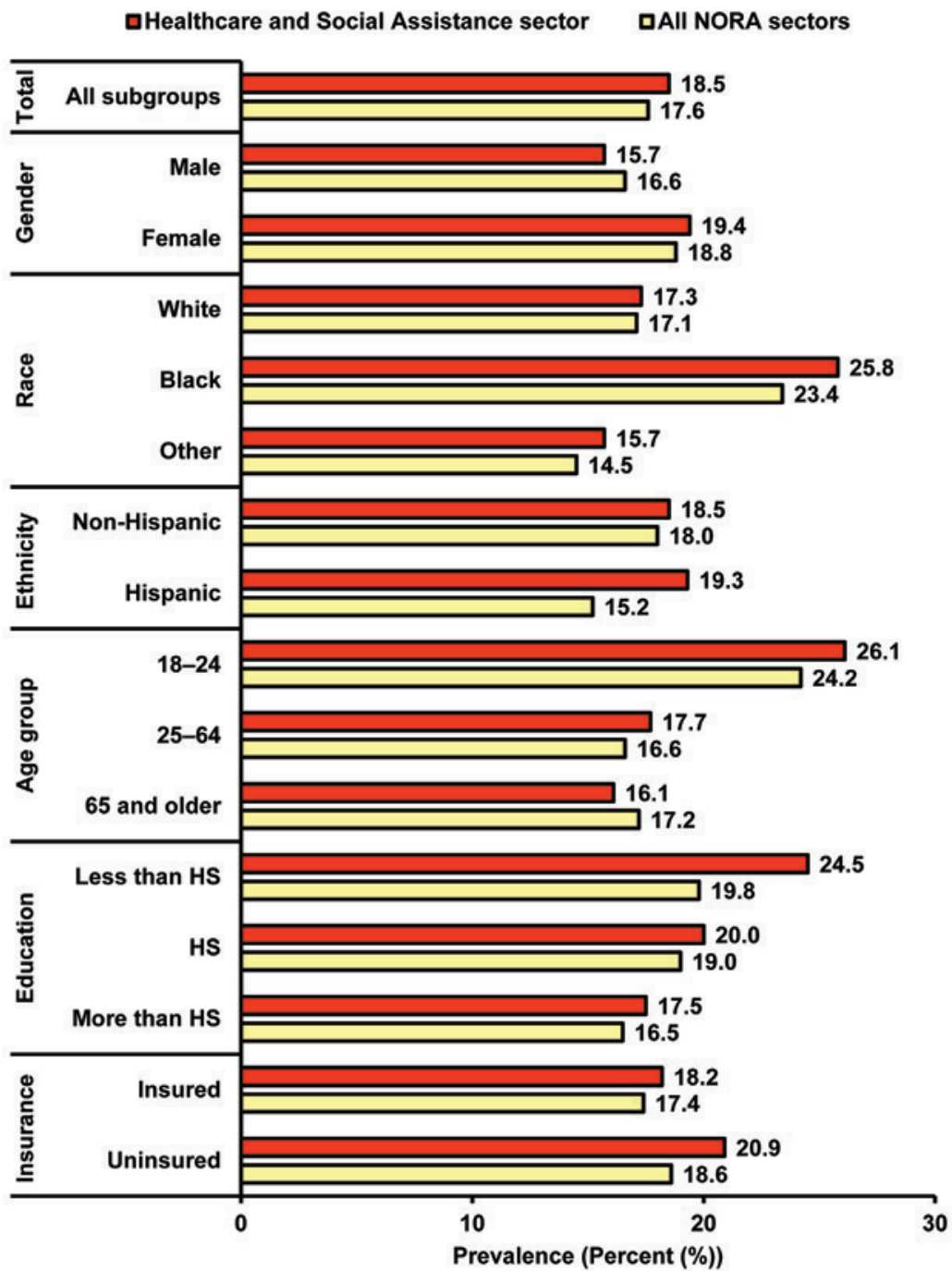




\section{Prevalence of current smokers estimated for workers 18 years and older}

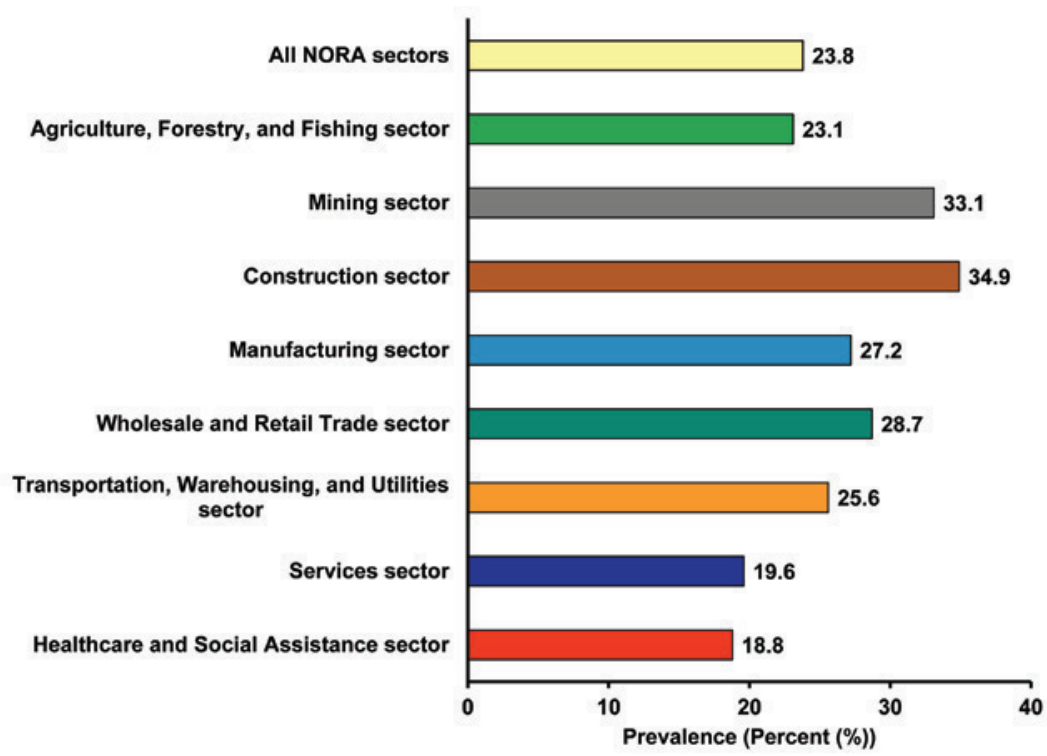

口Healthcare and Social Assistance sector QAll NORA sectors

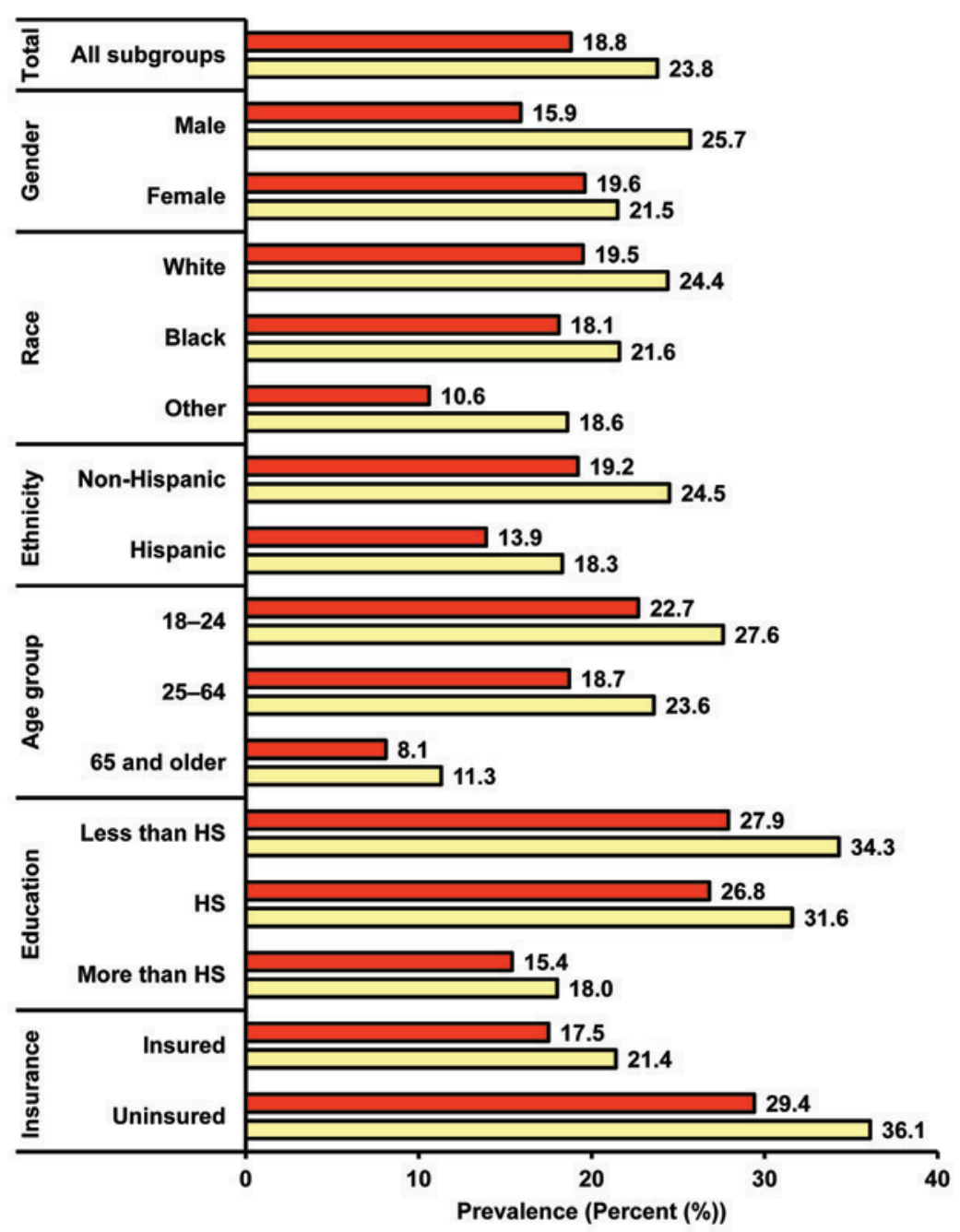

Figure 21a. Workers 18 years and older by NORA sectors, National Health Interview Survey, 1997-2007. An estimated $23.8 \%$ of employed U.S. workers reported being current smokers (see Table 2, page 42, and Tables 43 and 44, pages 84-85). Among the NORA sectors, Construction sector workers reported the highest prevalence of current smokers (34.9\%), while Healthcare and Social Assistance sector workers reported the lowest (18.8\%).

Figure 21b. Workers 18 years and older, Healthcare and Social Assistance sector and All NORA sectors, National Health Interview Survey, 1997-2007.

An estimated $18.8 \%$ of workers employed in the Healthcare and Social Assistance sector reported being current smokers. Among the subgroups, uninsured workers reported the highest prevalence of current smokers (29.4\%), while workers 65 years of age or older reported the lowest $(8.1 \%$ ) (see Table 44, page 85). Among all U.S. workers, uninsured workers reported the highest prevalence of current smokers (36.1\%), while workers 65 years of age or older reported the lowest (11.3\%). Workers with less than a high school education were more likely to report being current smokers than workers with more than a high school education (34.3\% vs. $18.0 \%$ ) (see Table 43, page 84). 


\section{Prevalence of current alcohol drinkers estimated for workers 18 years and older}

Figure 22a. Workers 18 years and older by NORA sectors, National Health Interview Survey, 1997-2007. An estimated $70.2 \%$ of employed U.S. workers reported being current alcohol drinkers (see Table 2, page 42, and Tables 45 and 46, pages 86-87). Among the NORA sectors, Construction sector workers reported the highest prevalence of current alcohol drinkers (75.0\%), while Healthcare and Social Assistance sector workers reported the lowest (64.8\%).

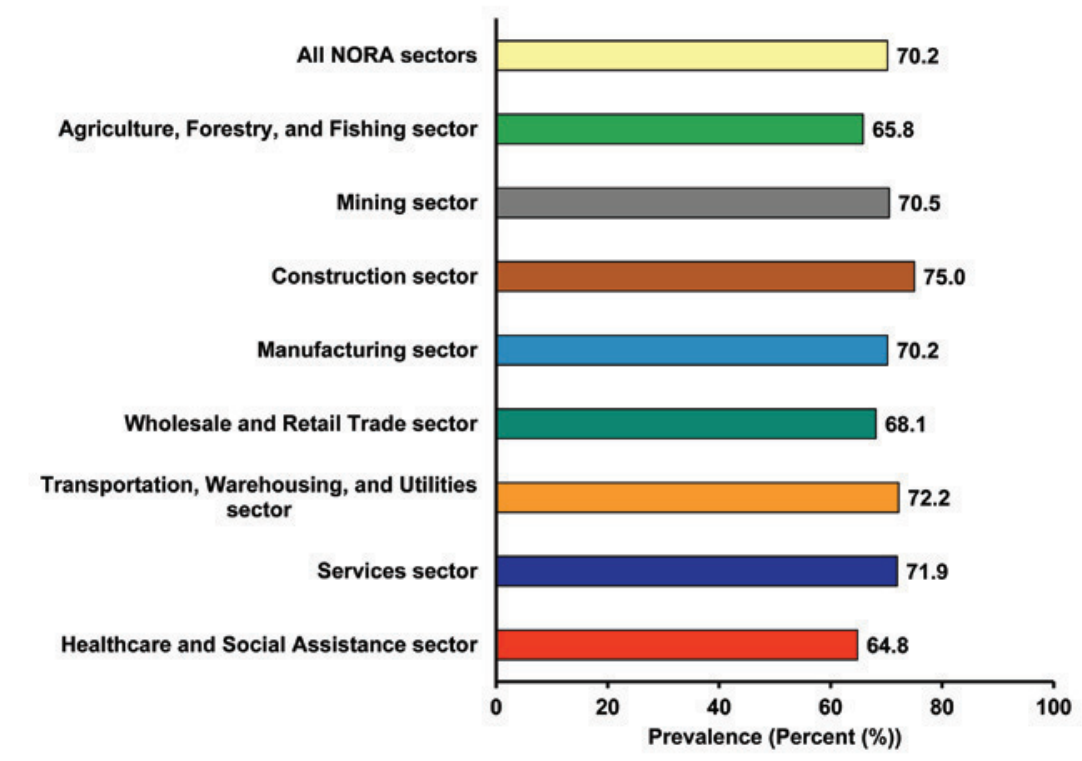

Figure 22b. Workers 18 years and older, Healthcare and Social Assistance sector and All NORA sectors, National Health Interview Survey, 1997-2007.

An estimated $64.8 \%$ of workers employed in the Healthcare and Social Assistance sector reported being current alcohol drinkers. Among the subgroups, white workers and workers with more than a high school education reported the highest prevalence of current alcohol drinkers (69.3\%), while workers with less than a high school education reported the lowest (42.6\%) (see Table 46, page 87). Among all U.S. workers, those with more than a high school education reported the highest prevalence of current alcohol drinkers (74.9\%), while workers 65 years of age or older reported the lowest (55.8\%) (see Table 45, page 86).

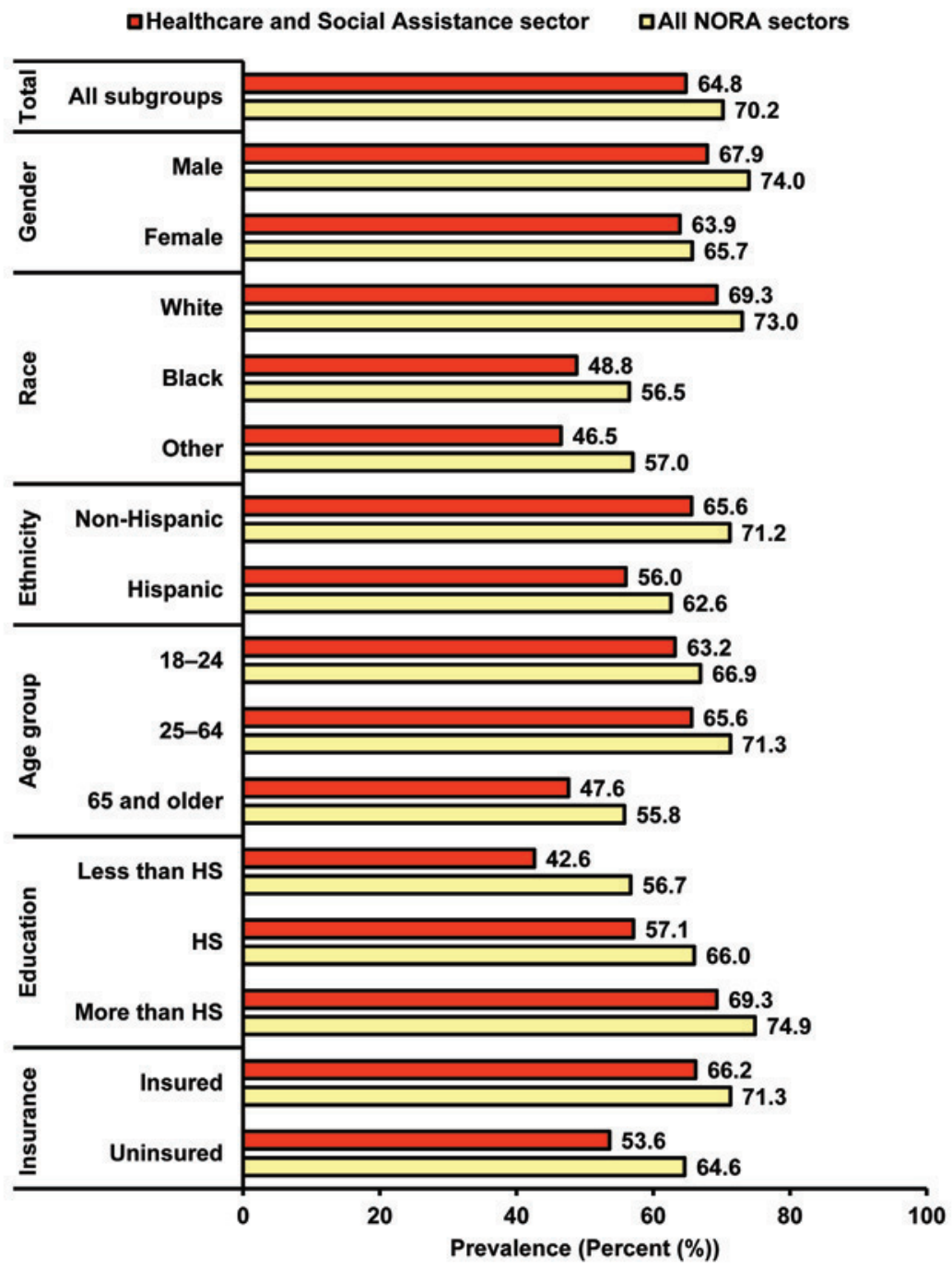




\section{Prevalence of obesity estimated for workers 18 years and older}
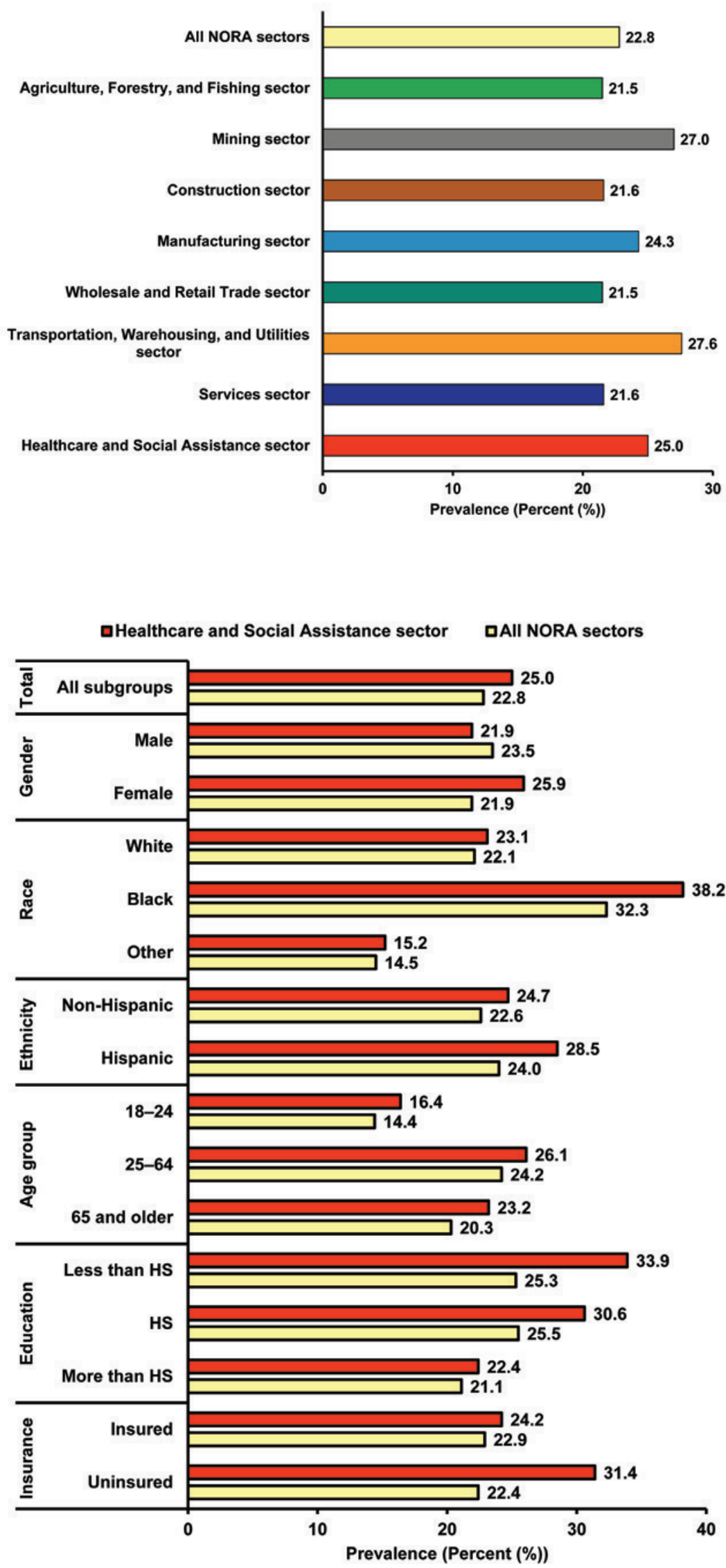

Figure 23a. Workers 18 years and older by NORA sectors, National Health Interview Survey, 1997-2007. An estimated $22.8 \%$ of all employed U.S. workers reported being obese (having a body mass index (BMI) greater than or equal to 30) (see Table 2, page 42, and Tables 47 and 48, pages 88-89). Among the NORA sectors, Transportation, Warehousing, and Utilities sector workers reported the highest prevalence of obesity (27.6\%), while Wholesale and Retail Trade sector and Agriculture, Forestry, and Fishing sector workers reported the lowest $(21.5 \%)$.

Figure 23b. Workers 18 years and older, Healthcare and Social Assistance sector and All NORA sectors, National Health Interview Survey, 1997-2007.

An estimated $25.0 \%$ of workers employed in the Healthcare and Social Assistance sector reported being obese (having a body mass index (BMI) greater than or equal to 30). Among the subgroups, Black workers reported the highest prevalence of obesity (38.2\%), while workers of "Other" race reported the lowest (15.2\%) (see Table 48, page 89). Among all U.S. workers, Black workers reported the highest prevalence of obesity (32.3\%), while workers 18-24 years of age reported the lowest (14.4\%). Obesity among Black workers was more than twice that noted for workers in the "Other" race group (32.3\% vs. 14.5\%) (see Table 47, page 88). 


\section{Prevalence of not meeting CDC recommended leisure time levels of physical activity estimated for workers 18 years and older}

Figure 24a. Workers 18 years and older by NORA sectors, National Health Interview Survey, 1997-2007. An estimated $65.9 \%$ of all employed U.S. workers reported not meeting recommended leisure time levels of physical activity (see Table 2, page 42, and Tables 49 and 50, pages 90-91). Among the NORA sectors, Agriculture, Forestry, and Fishing sector workers reported the highest prevalence of not meeting recommended leisure time levels of physical activity (73.5\%), while Services sector workers reported the lowest $(62.1 \%)$.

Figure 24b. Workers 18 years and older, Healthcare and Social Assistance sector and All NORA sectors, National Health Interview Survey, 1997-2007.

An estimated $65.6 \%$ of workers employed in the Healthcare and Social Assistance sector reported not meeting recommended leisure time levels of physical activity. Among the subgroups, workers with less than a high school education reported the highest prevalence of not meeting recommended leisure time levels of physical activity (80.8\%), while male workers reported the lowest (58.5\%) (see Table 50, page 91). Among all U.S. workers, those with less than a high school education reported the highest prevalence of not meeting recommended leisure time levels of physical activity $(78.9 \%)$, while workers with more than a high school education reported the lowest (60.0\%) (see Table 49 page 90 ).
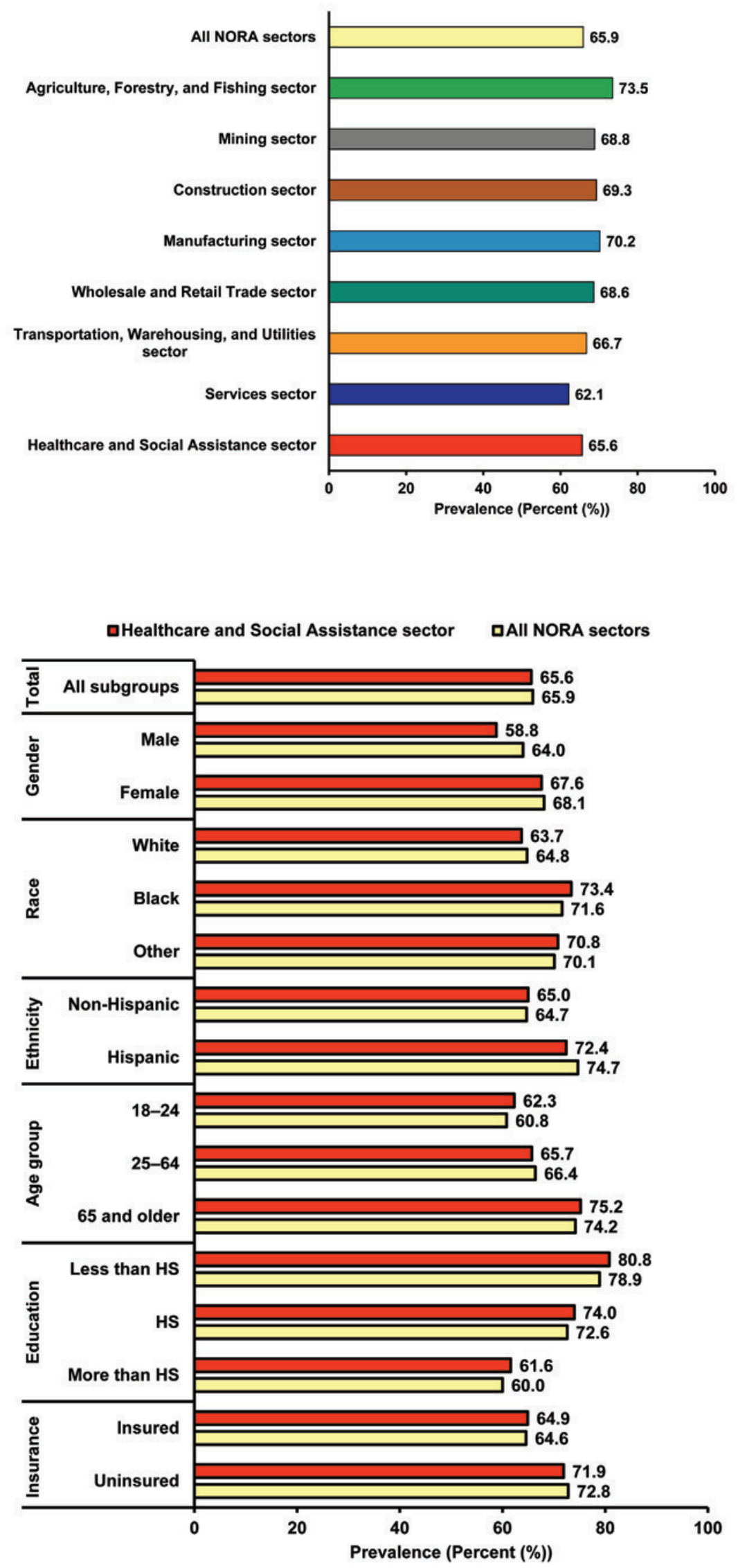


\section{Prevalence of lifetime HIV test estimated for workers 18 years and older}

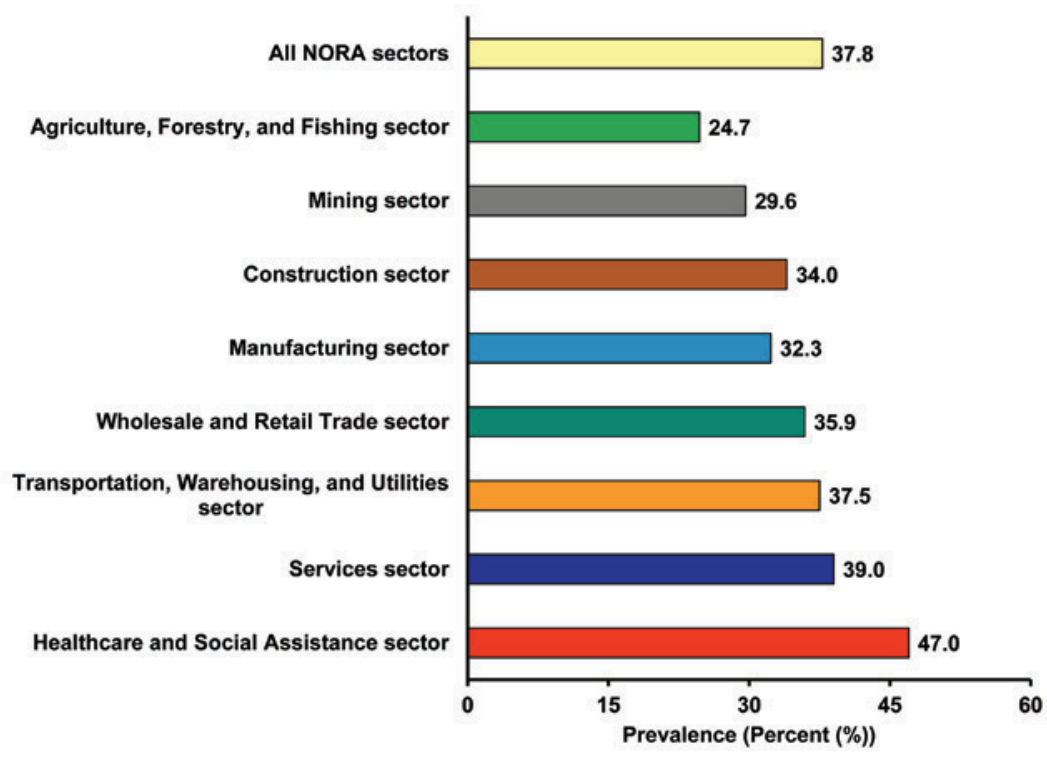

口Healthcare and Social Assistance sector

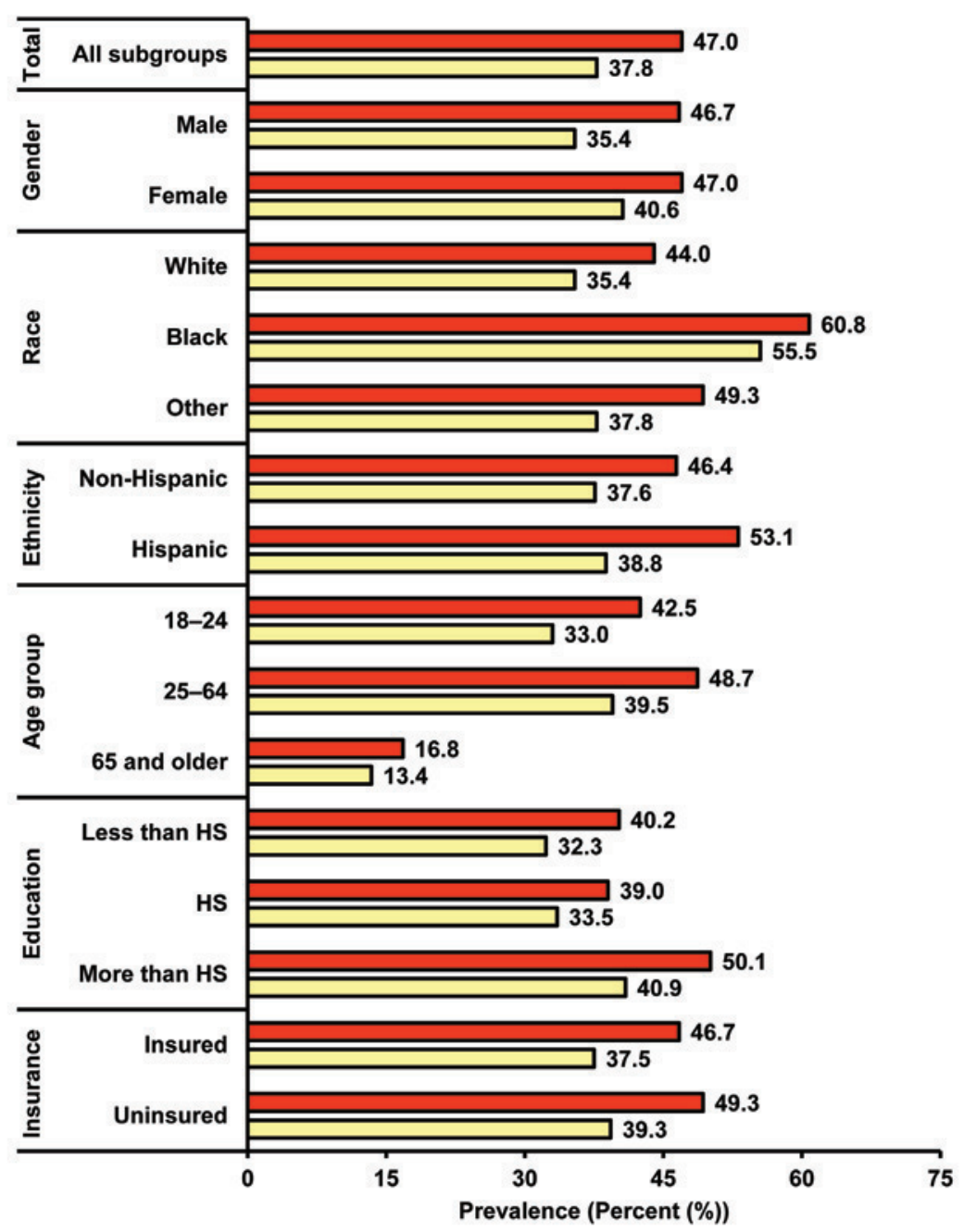

Figure 25a. Workers 18 years and older by NORA sectors, National Health Interview Survey, 1997-2007. An estimated $37.8 \%$ of all employed U.S. workers reported ever being tested for HIV (see Table 2, page 42, and Tables 51 and 52, pages 92-93). Among the NORA sectors, Healthcare and Social Assistance sector workers reported the highest prevalence of ever being tested for HIV (47.0\%), while Agriculture, Forestry, and Fishing sector workers reported the lowest (24.7\%).

Figure 25b. Workers 18 years and older, Healthcare and Social Assistance sector and All NORA sectors, National Health Interview Survey, 1997-2007.

An estimated $47.0 \%$ of workers employed in the Healthcare and Social Assistance sector reported ever being tested for HIV. Among the subgroups, Black workers reported the highest prevalence of ever being tested for HIV $(60.8 \%)$, while workers 65 years of age or older reported the lowest (16.8\%) (see Table 52, page 93). Among all U.S. workers, Black workers reported the highest prevalence of ever being tested for HIV (55.5\%), while workers 65 years of age or older reported the lowest prevalence (13.4\%) (see Table 51, page 92). 


\section{Prevalence of not receiving an influenza vaccination during the past 12 months estimated for workers 18 years and older}

Figure 26a. Workers 18 years and older by NORA sectors, National Health Interview Survey, 1997-2007. An estimated $79.1 \%$ of all employed U.S. workers reported not receiving an influenza vaccination during the past 12 months (see Table 2, page 42, and Tables 53 and 54, pages 94-95). Among the NORA sectors, Construction sector workers reported the highest prevalence of not receiving an influenza vaccination during the past 12 months (89.3\%), while Healthcare and Social Assistance sector workers reported the lowest (64.5\%).

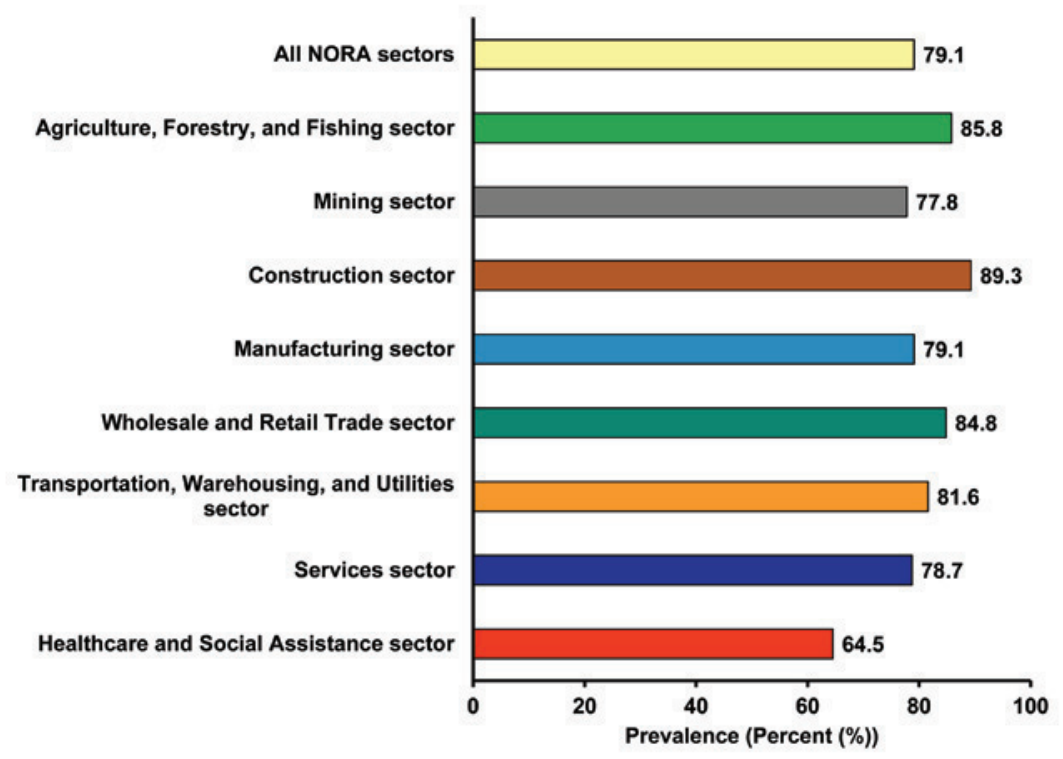

Figure 26b. Workers 18 years and older, Healthcare and Social Assistance sector and All NORA sectors, National Health Interview Survey, 1997-2007.

An estimated $64.5 \%$ of workers employed in the Healthcare and Social Assistance sector reported not receiving an influenza vaccination during the past 12 months. Among the subgroups, uninsured workers reported the highest prevalence of not receiving an influenza vaccination during the past 12 months (79.4\%), while workers 65 years of age or older reported the lowest (38.4\%) (see Table 54, page 95). Among all U.S. workers, uninsured workers reported the highest prevalence of not receiving an influenza vaccination during the past 12 months $(90.8 \%)$, while workers 65 years of age or older reported the lowest (42.9\%). A large proportion of workers 18-24 years of age also reported not receiving an influenza vaccination during the past 12 months (87.1\%) (see Table 53, page 94).

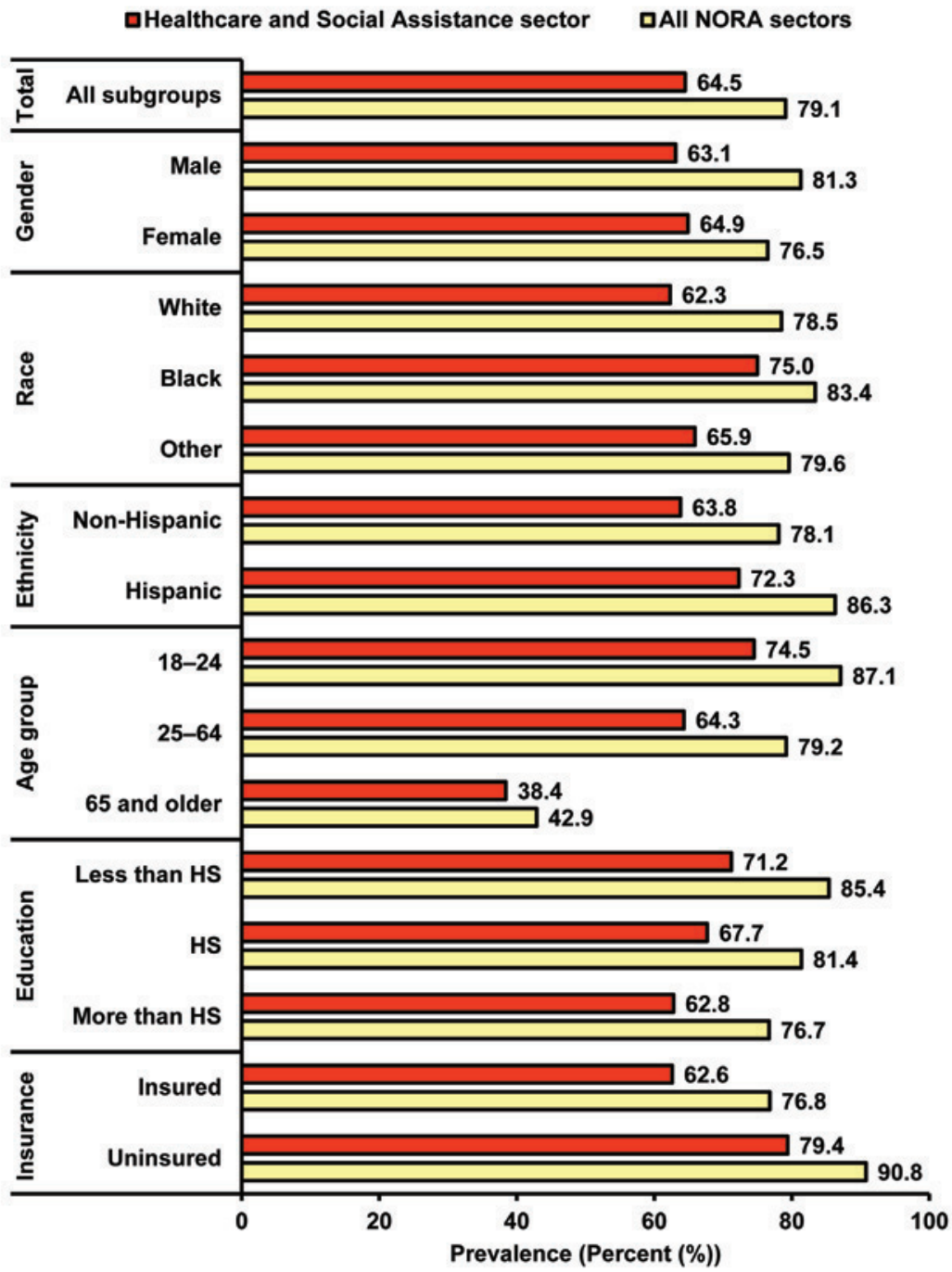




\section{Prevalence of never receiving a pneumococcal vaccination estimated for workers 60 years and older}

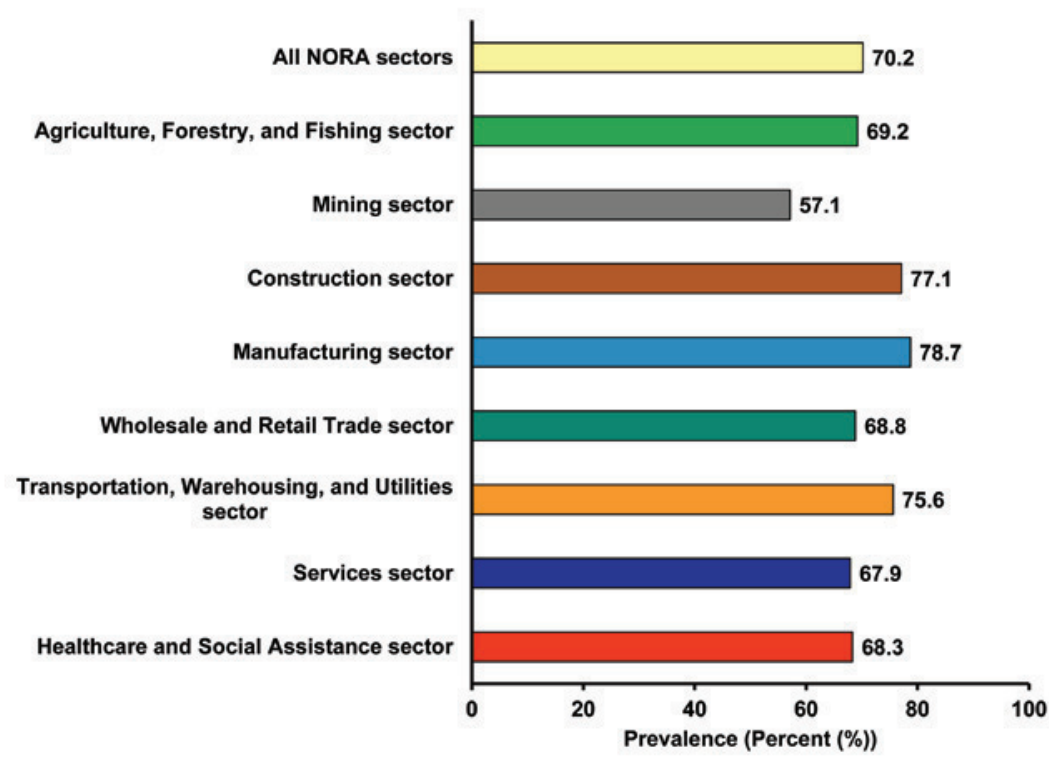

口Healthcare and Social Assistance sector

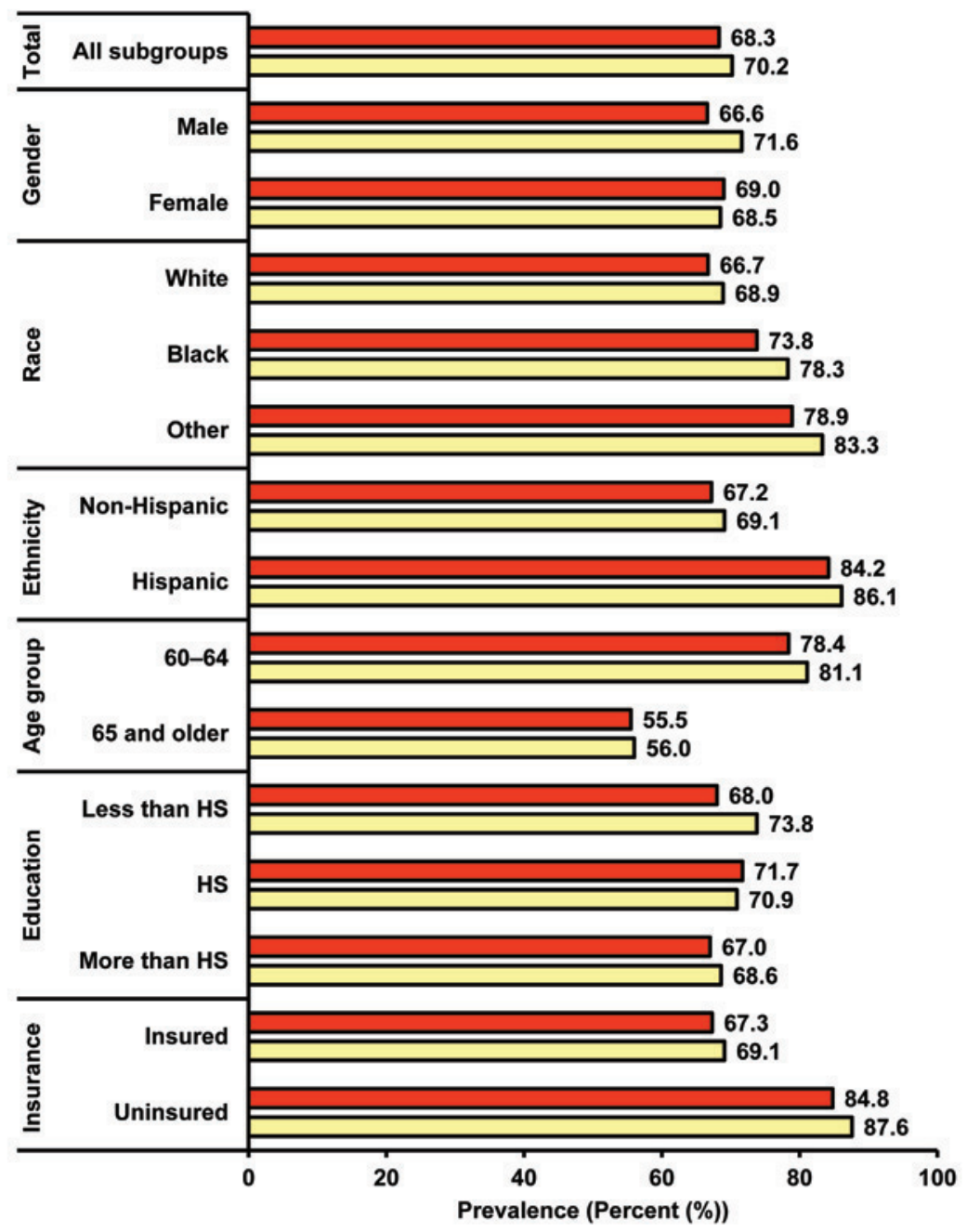

Figure 27a. Workers 60 years and older by NORA sectors, National Health Interview Survey, 1997-2007.

An estimated $70.2 \%$ of all employed U.S. workers 60 years and older reported never receiving a pneumococcal vaccination (see Table 2, page 42, and Tables 55 and 56, pages 96-97). Among the NORA sectors, Manufacturing sector workers reported the highest prevalence of never receiving a pneumococcal vaccination (78.7\%), while Mining sector workers reported the lowest $(57.1 \%)$.

Figure 27b. Workers 60 years and older, Healthcare and Social Assistance sector and All NORA sectors, National Health Interview Survey, 1997-2007.

An estimated $68.3 \%$ of workers 60 years and older employed in the Healthcare and Social Assistance sector reported never receiving a pneumococcal vaccination. Among the subgroups, uninsured workers reported the highest prevalence of never receiving a pneumococcal vaccination (84.8\%), while workers 65 years of age or older reported the lowest (55.5\%) (see Table 56, page 97). Among all U.S. workers, uninsured workers reported the highest prevalence of never receiving a pneumococcal vaccination $(87.6 \%)$, while workers 65 years of age or older reported the lowest $(56.0 \%)$. Hispanic workers reported lower pneumococcal vaccination rates relative to NonHispanics workers (13.9\% vs. 30.9\%) (see Table 55, page 96). 


\section{Tables}

Table 1. Estimated U.S. worker population and sample size for workers 18 years and older, All NORA sectors and Healthcare and Social Assistance sector ${ }^{1}$, National Health Interview Survey, 1997-2007

\begin{tabular}{|c|c|c|c|c|c|c|}
\hline \multirow{3}{*}{ Subgroup } & \multicolumn{3}{|c|}{ All NORA sectors } & \multicolumn{3}{|c|}{$\begin{array}{l}\text { Healthcare and Social Assistance } \\
\text { sector }\end{array}$} \\
\hline & \multicolumn{2}{|c|}{$\begin{array}{c}\text { U.S. Worker Population } \\
\text { Estimates }\end{array}$} & \multirow[t]{2}{*}{ NHIS N ${ }^{1}$} & \multicolumn{2}{|c|}{$\begin{array}{c}\text { U.S. Worker Population } \\
\text { Estimates }\end{array}$} & \multirow[t]{2}{*}{ NHIS N ${ }^{1}$} \\
\hline & Number & Percent (\%) & & Number & Percent (\%) & \\
\hline $\begin{array}{l}\text { Overall Total } \\
\text { Gender }\end{array}$ & $126,898,030$ & $100.0 \%$ & 196,924 & $16,548,227$ & $100.0 \%$ & 27,304 \\
\hline Male & $68,530,792$ & $54.0 \%$ & 97,768 & $3,725,120$ & $22.5 \%$ & 5,375 \\
\hline Female & $58,367,238$ & $46.0 \%$ & 99,156 & $12,823,107$ & $77.5 \%$ & 21,929 \\
\hline \multicolumn{7}{|l|}{ Race } \\
\hline White & $105,313,053$ & $83.0 \%$ & 157,040 & $12,980,558$ & $78.4 \%$ & 20,119 \\
\hline Black & $14,056,560$ & $11.1 \%$ & 27,262 & $2,608,720$ & $15.8 \%$ & 5,554 \\
\hline Other & $7,528,417$ & $5.9 \%$ & 12,622 & 958,949 & $5.8 \%$ & 1,631 \\
\hline \multicolumn{7}{|l|}{ Ethnicity } \\
\hline Non-Hispanic & $111,862,532$ & $88.2 \%$ & 163,004 & $15,172,660$ & $91.7 \%$ & 23,735 \\
\hline Hispanic & $15,035,498$ & $11.8 \%$ & 33,920 & $1,375,568$ & $8.3 \%$ & 3,569 \\
\hline \multicolumn{7}{|l|}{ Age group } \\
\hline $18-24$ & $16,959,193$ & $13.4 \%$ & 21,858 & $1,725,603$ & $10.4 \%$ & 2,299 \\
\hline $25-64$ & $105,946,456$ & $83.5 \%$ & 167,739 & $14,247,961$ & $86.1 \%$ & 23,836 \\
\hline 65 and older & $3,992,381$ & $3.1 \%$ & 7,327 & 574,664 & $3.5 \%$ & 1,169 \\
\hline \multicolumn{7}{|l|}{ Education $^{2}$} \\
\hline Less than high school graduate & $14,798,890$ & $11.7 \%$ & 26,367 & $1,141,190$ & $6.9 \%$ & 2,376 \\
\hline High school graduate or GED & $36,048,733$ & $28.4 \%$ & 54,264 & $3,582,213$ & $21.6 \%$ & 6,011 \\
\hline Some college or higher & $75,434,176$ & $59.4 \%$ & 115,325 & $11,751,646$ & $71.0 \%$ & 18,800 \\
\hline Insurance & & & & & & \\
\hline Insured & $106,279,655$ & $83.8 \%$ & 161,665 & $14,662,946$ & $88.6 \%$ & 23,754 \\
\hline Uninsured & $20,282,002$ & $16.0 \%$ & 34,830 & $1,839,325$ & $11.1 \%$ & 3,495 \\
\hline
\end{tabular}

1 Sample size (N) from the National Health Interview Survey (NHIS) for the years 1997-2007.

2 Response categoroes include (1) less than High School graduate, (2) High School graduate or GED, and (3) Some college or higher education. Note: Subgroup percentages may not total $100 \%$ due to missing covariate values. Sample weights are also used to estimate the number of workers in the U.S. with various health conditions. In some cases these values will be underestimates due to either (1) the presence of missing data for the condition of interest (e.g., respondent did not respond to a chronic disease condition), or (2) in the case of stratified analyses, there are missing values for the stratification variable (e.g., educational attainment). 


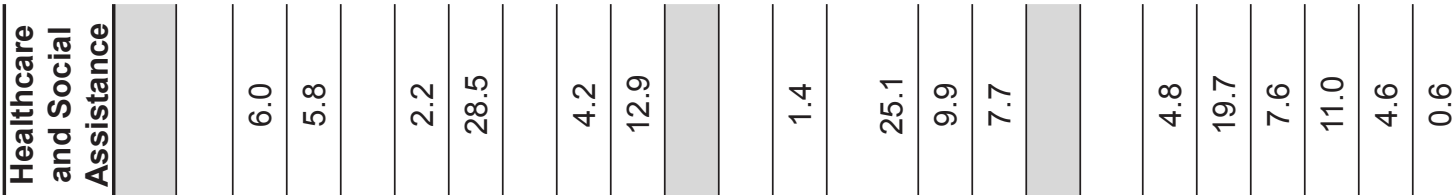

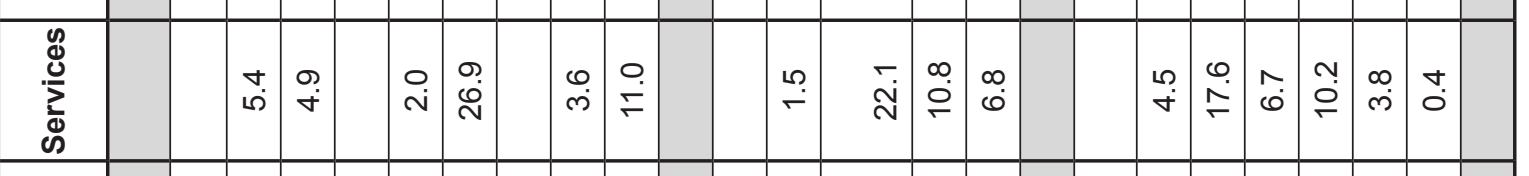

도 ำ

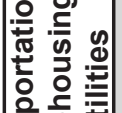

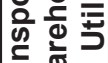

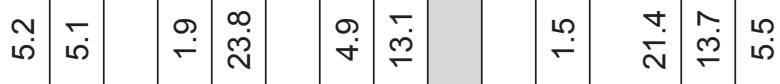

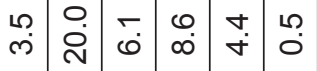

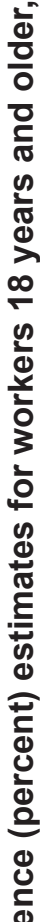

(5)

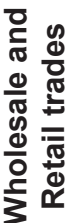

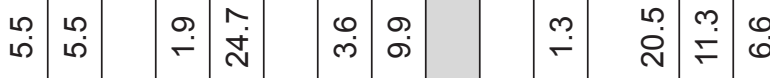

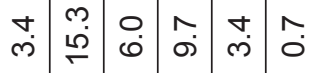

$\stackrel{\infty}{\infty}$

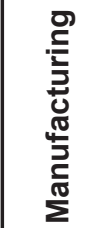

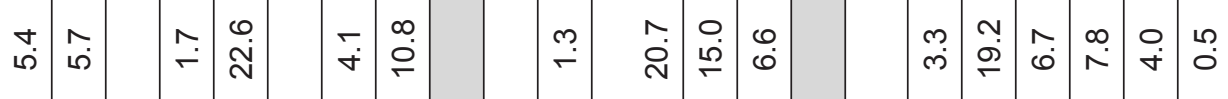

을

政

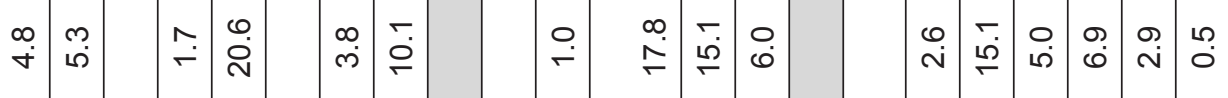

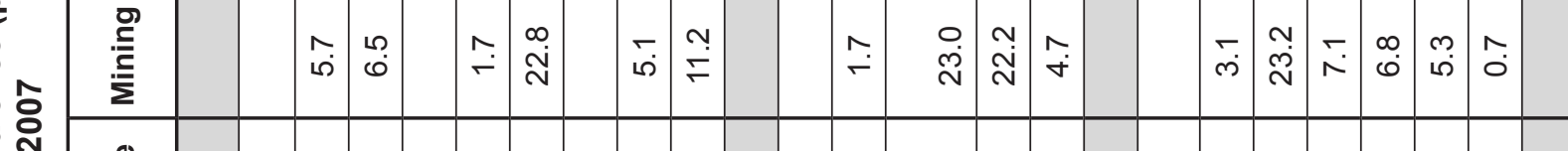

ปิ่

gे

훙

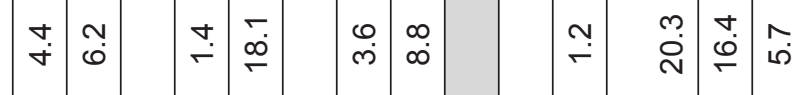

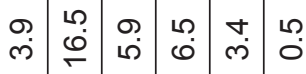

은

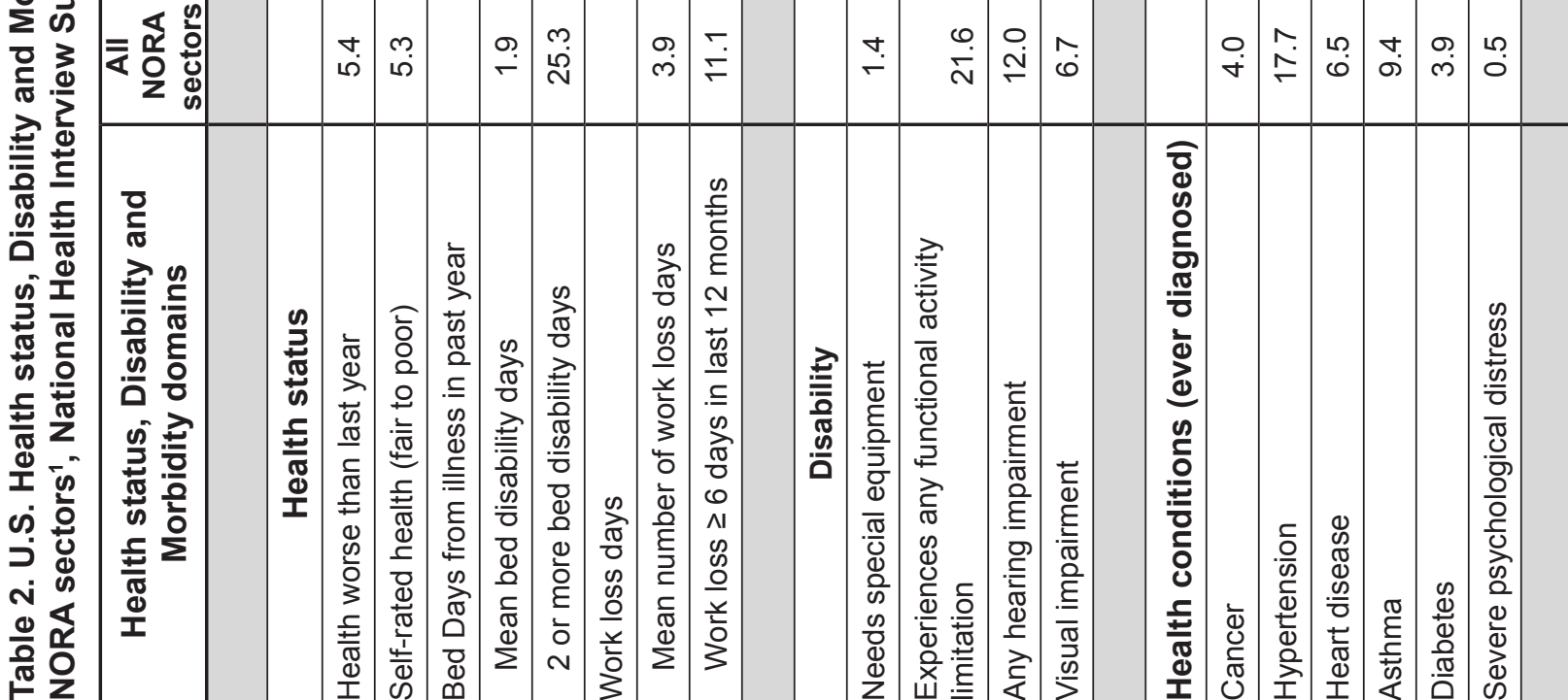




\begin{tabular}{|c|c|c|c|c|c|c|c|c|c|c|c|c|c|c|}
\hline 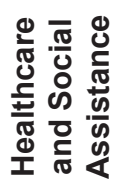 & & $\begin{array}{l}0 \\
\stackrel{\sim}{ }\end{array}$ & 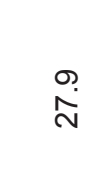 & $\begin{array}{l}\stackrel{0}{\sim} \\
\stackrel{\sim}{-}\end{array}$ & $\begin{array}{l}\stackrel{0}{0} \\
\infty \\
\infty\end{array}$ & & $\begin{array}{l}\infty \\
\infty \\
\infty\end{array}$ & $\begin{array}{l}\infty \\
\dot{\sigma}\end{array}$ & 웅 & $\begin{array}{l}0 \\
\dot{0} \\
0\end{array}$ & $\stackrel{\circ}{\stackrel{\gamma}{\gamma}}$ & $\begin{array}{l}0 \\
\dot{\sigma}\end{array}$ & $\begin{array}{l}m \\
0 \\
0\end{array}$ & 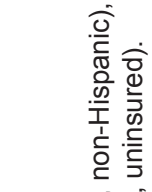 \\
\hline 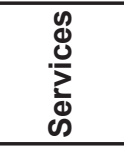 & & $\begin{array}{l}\stackrel{m}{ } \\
\stackrel{\sim}{ }\end{array}$ & $\begin{array}{l}\text { ㅇ.ं } \\
\text { ه্ }\end{array}$ & $\stackrel{m}{\leftarrow}$ & $\stackrel{\circ}{\stackrel{2}{\leftarrow}}$ & & $\begin{array}{l}\stackrel{\bullet}{\sigma} \\
\stackrel{\sigma}{\sigma}\end{array}$ & $\frac{\Omega}{\grave{N}}$ & $\frac{0}{\grave{N}}$ & ָָ & 일 & $\hat{\infty}$ & ๙̊. & 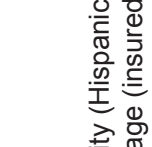 \\
\hline 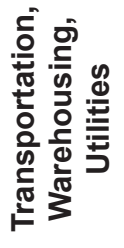 & & $\begin{array}{l}\text { No } \\
\text { ○े }\end{array}$ & 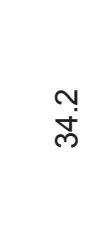 & $\stackrel{\sim}{\circ}$ & $\begin{array}{l}\circ \\
\infty \\
\infty\end{array}$ & & $\begin{array}{l}\stackrel{\varphi}{\sim} \\
\stackrel{\sim}{N}\end{array}$ & $\stackrel{N}{N}$ & $\stackrel{0}{N}$ & ڤ̊ & مٍ & $\frac{0}{\infty}$ & $\begin{array}{l}\stackrel{0}{\circ} \\
\stackrel{0}{N}\end{array}$ & 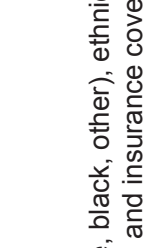 \\
\hline 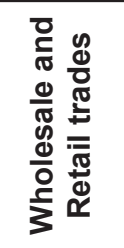 & & ભ̊ & 일 & $\check{\circ}$ & $\check{\sigma}$ & & 㝏 & $\overline{0}$ & $\frac{n}{\grave{N}}$ & $\begin{array}{l}0 \\
0 \\
0 \\
0\end{array}$ & $\begin{array}{l}\infty \\
\stackrel{\rho}{\circ}\end{array}$ & $\begin{array}{l}\infty \\
\dot{\infty}\end{array}$ & $\begin{array}{l}\infty \\
\infty 0^{\circ} \\
0\end{array}$ & 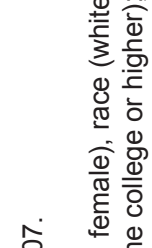 \\
\hline 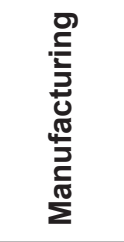 & & $\begin{array}{l}0 \\
\stackrel{\sim}{m}\end{array}$ & $\begin{array}{l}\infty \\
\stackrel{n}{~}\end{array}$ & $\stackrel{\sim}{\circ}$ & $\begin{array}{l}\infty \\
\oplus \\
\bullet\end{array}$ & & N & ִָ & $\stackrel{m}{\stackrel{\sim}{\sim}}$ & 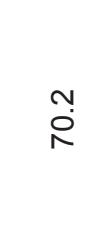 & m̃ & $\check{\Gamma}$ & $\stackrel{\wedge}{\infty}$ & 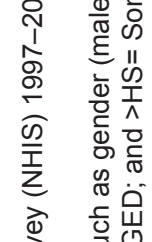 \\
\hline 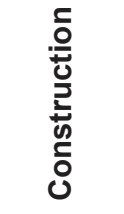 & & $\begin{array}{l}\stackrel{0}{\circ} \\
\stackrel{8}{+}\end{array}$ & $\begin{array}{l}m \\
\infty \\
\infty\end{array}$ & $\stackrel{\circ}{\infty}$ & $\stackrel{\infty}{\leftarrow}$ & & 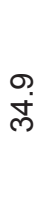 & 웅 & $\stackrel{\varphi}{\grave{N}}$ & $\begin{array}{l}\text { అొ } \\
\text { ஓं }\end{array}$ & ○् & $\begin{array}{l}m \\
\infty \\
\infty\end{array}$ & $\tilde{N}$ & 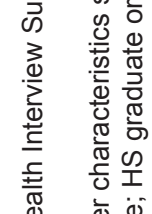 \\
\hline 올 & & ঢ্ं & $\dot{\check{\vartheta}}$ & $\stackrel{?}{\circ}$ & $\stackrel{\nabla}{\circ}$ & & $\dot{m}$ & م & ㅇ. & $\begin{array}{l}\infty \\
\infty \\
\infty \\
0\end{array}$ & $\begin{array}{l}0 \\
\stackrel{N}{N}\end{array}$ & $\stackrel{\infty}{N}$ & זٓ & 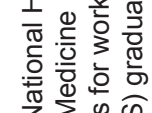 \\
\hline $\begin{array}{l}\frac{0}{2} \\
\frac{ \pm}{3} \\
\frac{0}{5} \\
\frac{0}{4}\end{array}$ & & சं & $\begin{array}{l}\text { m. } \\
\text { ○̊ }\end{array}$ & $\underset{\infty}{\stackrel{+}{ }}$ & $\begin{array}{l}\mathscr{\sim} \\
\leftarrow\end{array}$ & & ஸें & $\begin{array}{l}\infty \\
10 \\
0\end{array}$ & $\stackrel{\sim}{\grave{N}}$ & مִ & $\stackrel{\sim}{\stackrel{\sim}{\sim}}$ & $\begin{array}{l}\infty \\
\infty \\
\infty\end{array}$ & ָั & 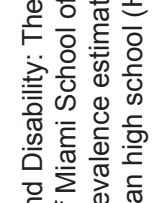 \\
\hline$=\frac{1}{\alpha} \frac{n}{0}$ & & $\begin{array}{l}\text { N̦ } \\
\text { Oे }\end{array}$ & $\begin{array}{l}\text { N } \\
\text { m }\end{array}$ & $\stackrel{\infty}{\circ} \stackrel{\circ}{\circ}$ & $\stackrel{\varphi}{\stackrel{0}{\sigma}}$ & & $\stackrel{\infty}{\stackrel{N}{N}}$ & No & $\stackrel{\infty}{\underset{N}{N}}$ & $\begin{array}{l}\text { の } \\
\stackrel{0}{0}\end{array}$ & 㐫. & ウं & $\stackrel{\sim}{\circ}$ & 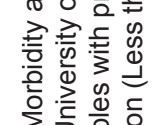 \\
\hline 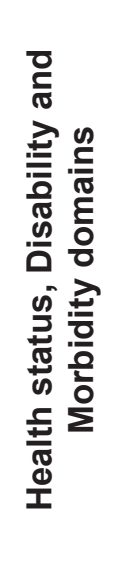 & 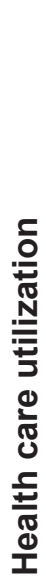 & 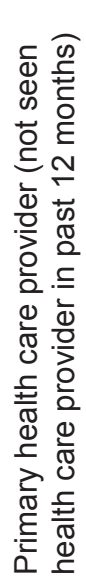 & 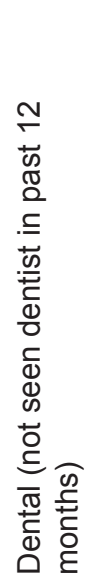 & 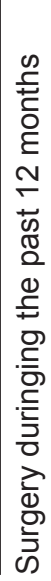 & 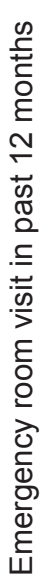 & 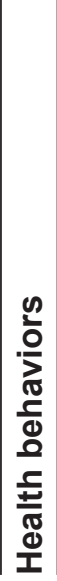 & 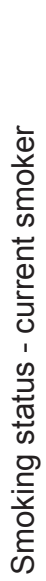 & 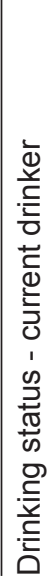 & 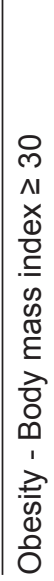 & 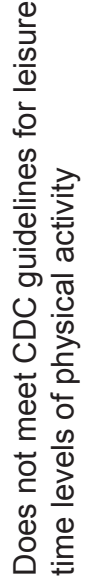 & 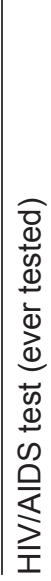 & 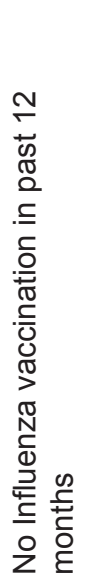 & 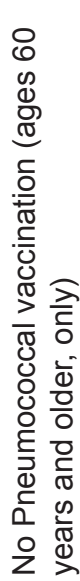 & 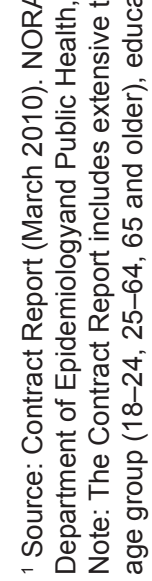 \\
\hline
\end{tabular}




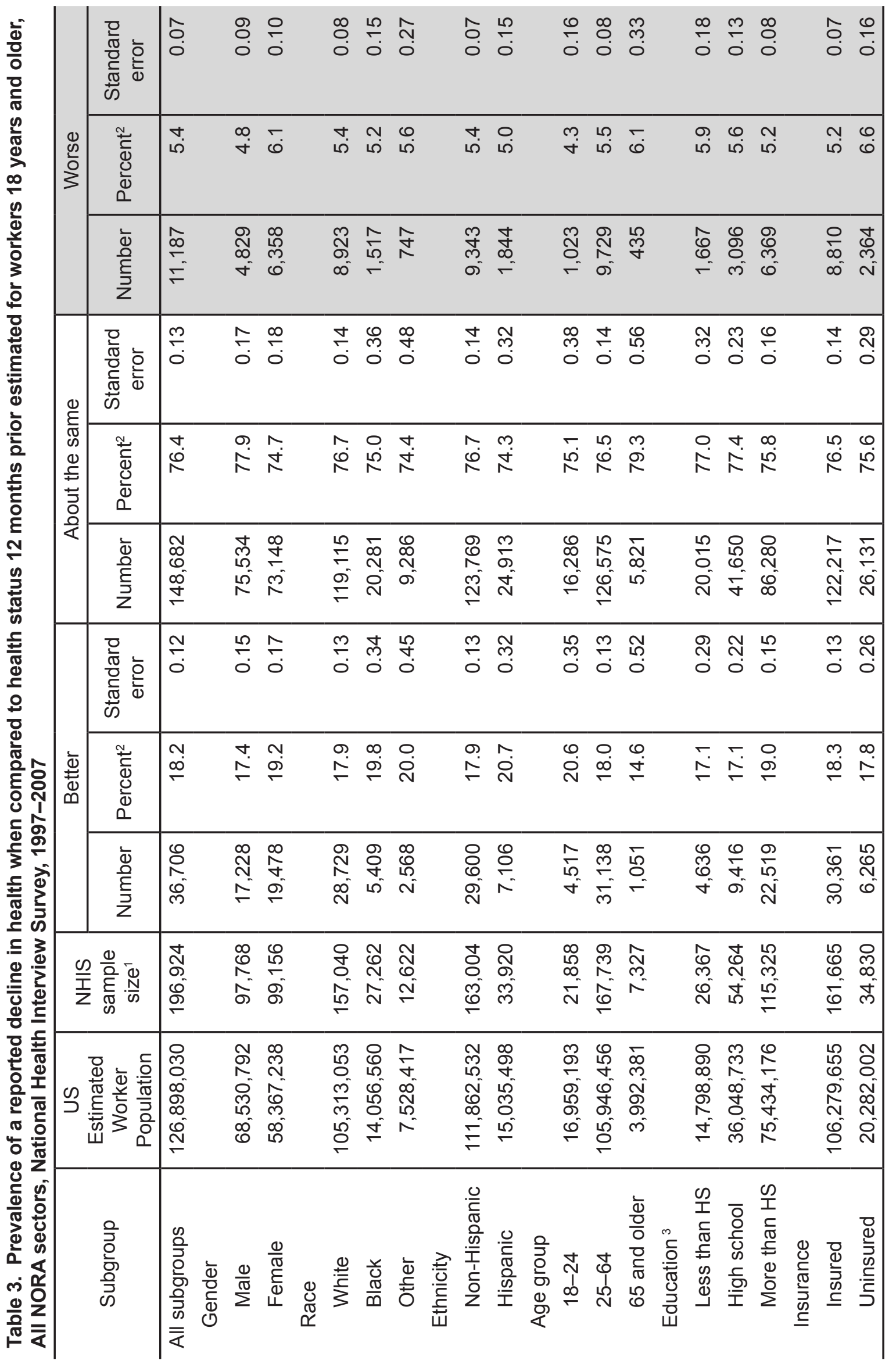

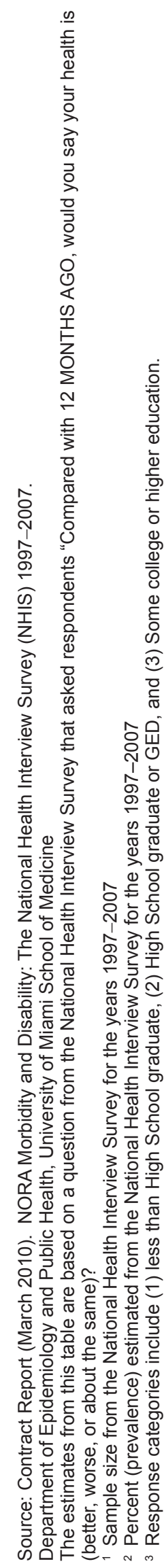




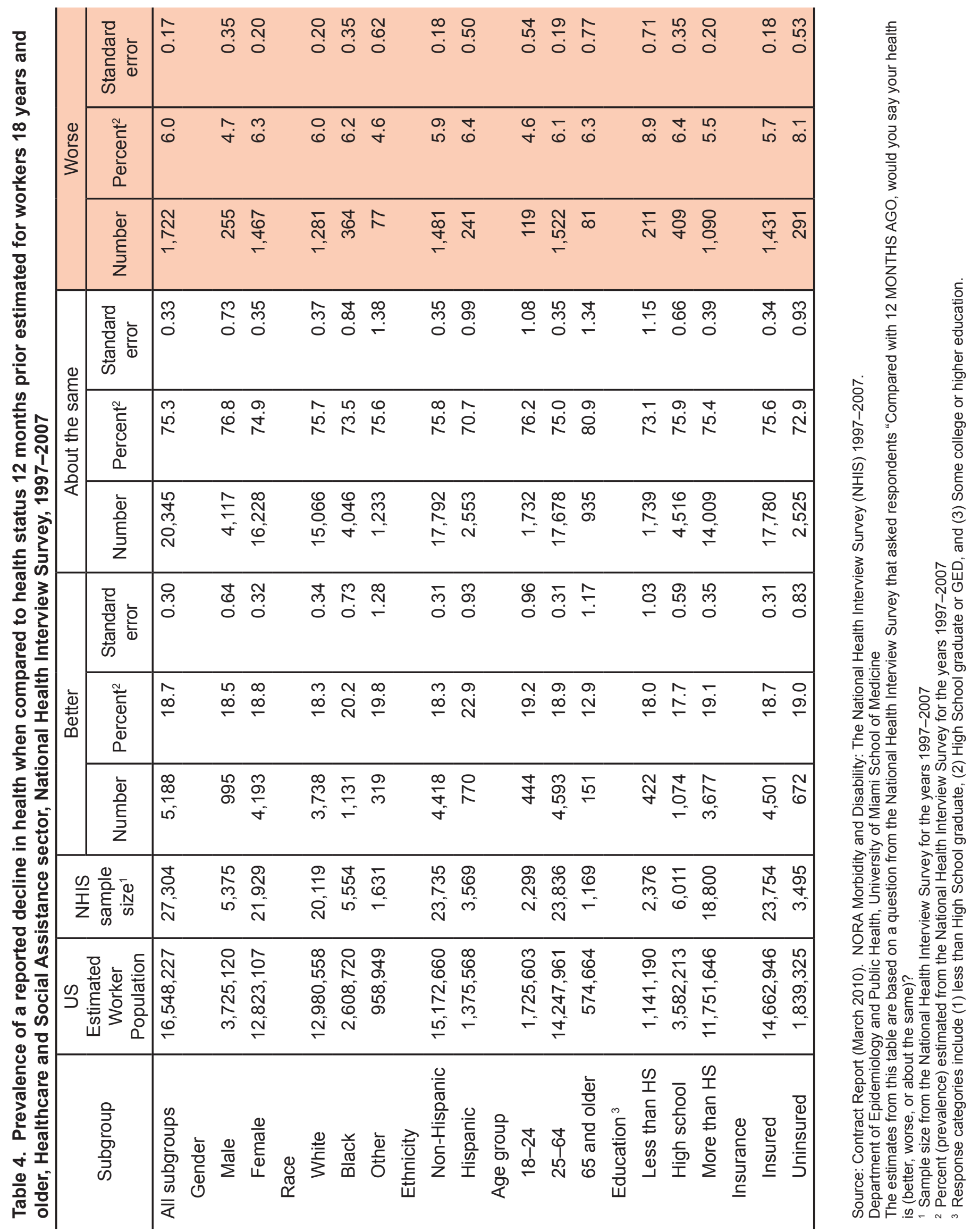




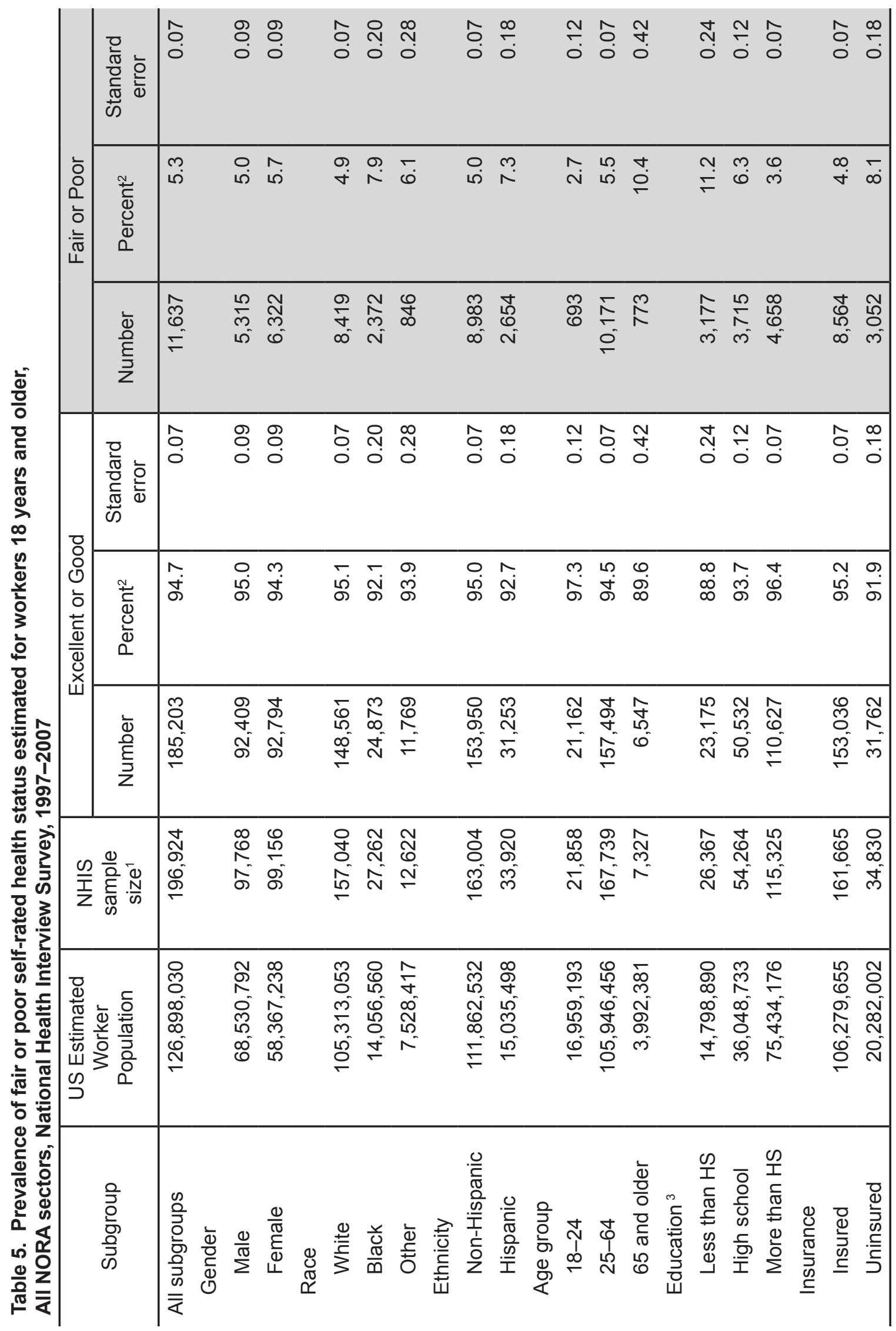

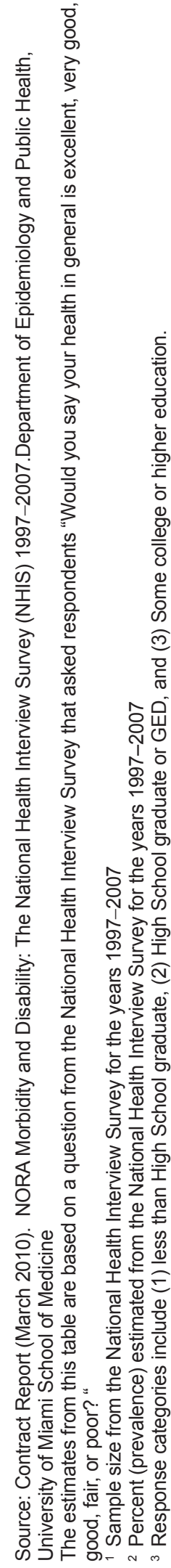




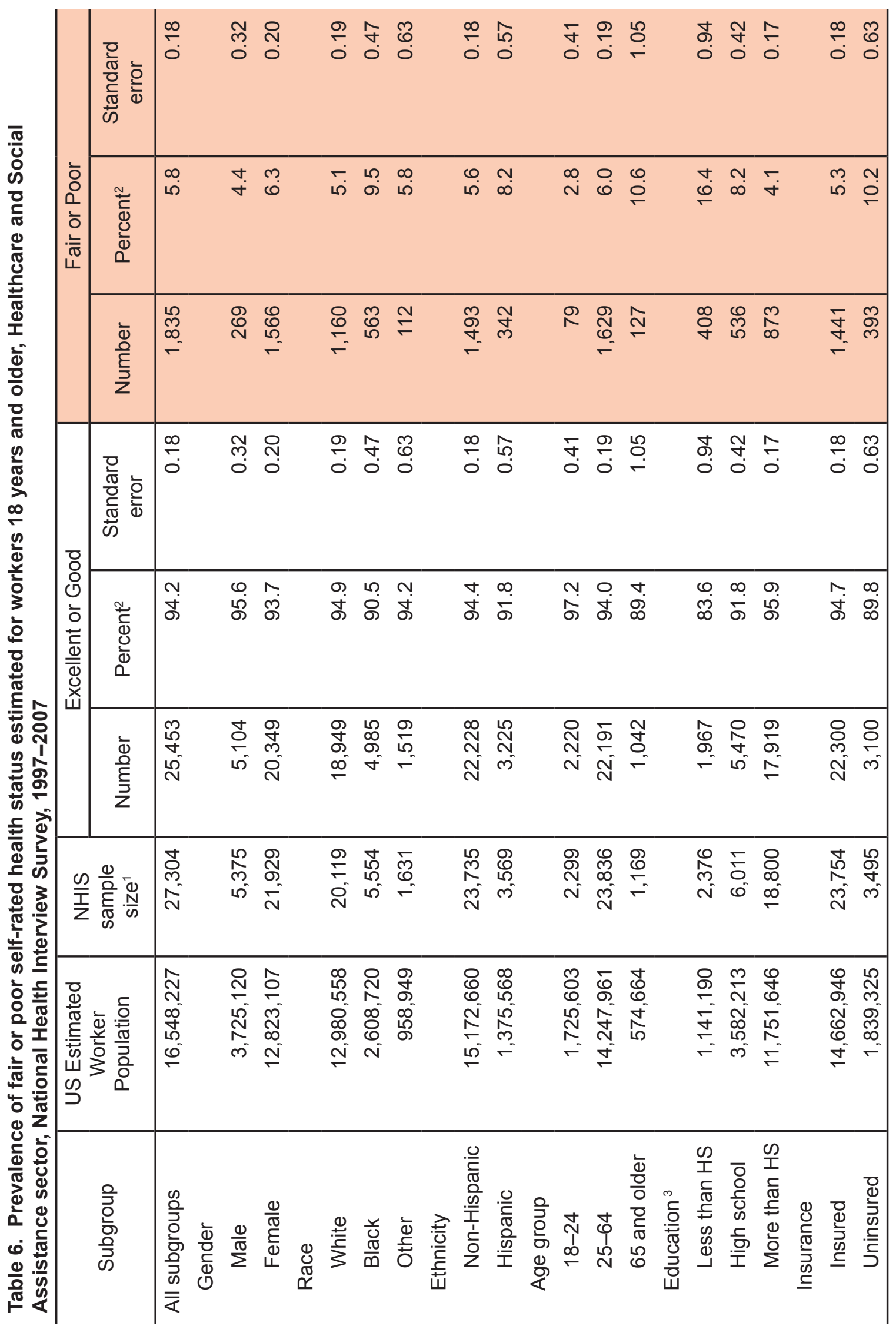

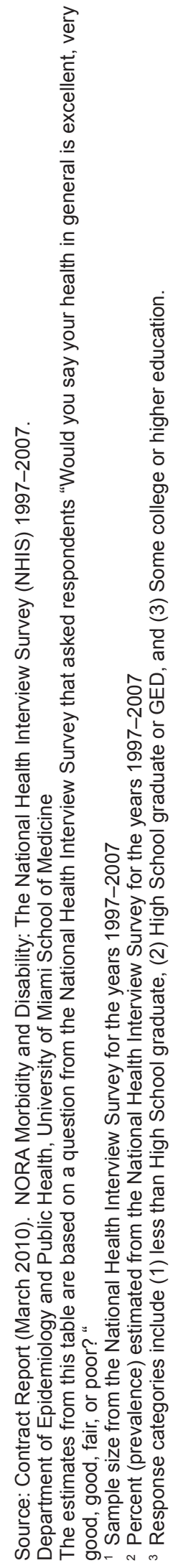


Table 7. Mean number of bed disability days during the past 12 months estimated for workers 18 years and older, All NORA sectors, National Health Interview Survey, 1997-2007

\begin{tabular}{|c|c|c|c|c|c|}
\hline Subgroup & $\begin{array}{c}\text { US Estimated } \\
\text { Worker } \\
\text { Population }\end{array}$ & $\begin{array}{l}\text { NHIS sample } \\
\text { size }^{1}\end{array}$ & Mean & $\begin{array}{c}95 \% \text { confidence } \\
\text { interval }\end{array}$ & Standard error \\
\hline \multicolumn{6}{|l|}{ Gender } \\
\hline Male & $68,530,792$ & 97,078 & 1.5 & $1.4--1.6$ & 0.03 \\
\hline Female & $58,367,238$ & 98,340 & 2.4 & $2.3--2.5$ & 0.04 \\
\hline \multicolumn{6}{|l|}{ Race } \\
\hline White & $105,313,053$ & 155,967 & 1.9 & 1.9--1.9 & 0.03 \\
\hline Black & $14,056,560$ & 26,948 & 2.1 & 2.0--2.2 & 0.06 \\
\hline Other & $7,528,417$ & 12,503 & 1.6 & $1.4--1.8$ & 0.09 \\
\hline \multicolumn{6}{|l|}{ Ethnicity } \\
\hline Non-Hispanic & $111,862,532$ & 161,751 & 2.0 & 2.0--2.0 & 0.02 \\
\hline Hispanic & $15,035,498$ & 33,667 & 1.4 & $1.3--1.5$ & 0.05 \\
\hline \multicolumn{6}{|l|}{ Age group } \\
\hline 18-24 & $16,959,193$ & 21,700 & 1.9 & $1.8--2.0$ & 0.07 \\
\hline $25-64$ & $105,946,456$ & 166,457 & 1.9 & $1.9--1.9$ & 0.03 \\
\hline 65 and older & $3,992,381$ & 7,261 & 1.9 & $1.6--2.2$ & 0.18 \\
\hline \multicolumn{6}{|l|}{ Education $^{2}$} \\
\hline Less than HS & $14,798,890$ & 26,119 & 1.9 & $1.7--2.1$ & 0.08 \\
\hline High school & $36,048,733$ & 53,809 & 2.0 & 1.9--2.1 & 0.04 \\
\hline More than HS & $75,434,176$ & 114,659 & 1.9 & 1.9--1.9 & 0.02 \\
\hline Insurance & & & & & \\
\hline Insured & $106,279,655$ & 160,491 & 1.9 & $1.9--1.9$ & 0.02 \\
\hline Uninsured & $20,282,002$ & 34,516 & 2.0 & 1.9--2.1 & 0.06 \\
\hline
\end{tabular}

Source: Contract Report (March 2010). NORA Morbidity and Disability: The National Health Interview Survey (NHIS) 1997-2007.Department of Epidemiology and Public Health, University of Miami School of Medicine

The estimates from this table are based on a question from the National Health Interview Survey that asked respondents "During the PAST 12 MONTHS ABOUT how many days did illness or injury keep you in bed for more than half the day? (include days while an overnight patient in a hospital)."

1 Sample size from the National Health Interview Survey for the years 1997-2007

${ }^{2}$ Response categories include (1) less than High School graduate, (2) High School graduate or GED, and (3) Some college or higher education. 
Table 8. Mean number of bed disability days during the past 12 months estimated for workers 18 years and older, Healthcare and Social Assistance sector, National Health Interview Survey, 1997-2007

\begin{tabular}{|c|c|c|c|c|c|}
\hline Subgroup & $\begin{array}{c}\text { US Estimated } \\
\text { Worker } \\
\text { Population }\end{array}$ & $\begin{array}{l}\text { NHIS sample } \\
\text { size }^{1}\end{array}$ & Mean & $\begin{array}{c}95 \% \text { confidence } \\
\text { interval }\end{array}$ & Standard error \\
\hline $\begin{array}{l}\text { All subgroups } \\
\text { Gender }\end{array}$ & $16,548,227$ & 27,060 & 2.2 & $2.1-2.3$ & 0.06 \\
\hline Male & $3,725,120$ & 5,333 & 1.4 & $1.2-1.6$ & 0.09 \\
\hline $\begin{array}{l}\text { Female } \\
\text { Race }\end{array}$ & $12,823,107$ & 21,727 & 2.4 & $2.3-2.5$ & 0.07 \\
\hline White & $12,980,558$ & 19,988 & 2.2 & $2.1-2.3$ & 0.07 \\
\hline Black & $2,608,720$ & 5,461 & 2.5 & $2.2-2.8$ & 0.13 \\
\hline $\begin{array}{c}\text { Other } \\
\text { Ethnicity }\end{array}$ & 958,949 & 1,611 & 1.6 & $1.3-1.9$ & 0.15 \\
\hline Non-Hispanic & $15,172,660$ & 23,521 & 2.2 & $2.1-2.3$ & 0.06 \\
\hline $\begin{array}{l}\text { Hispanic } \\
\text { Age group }\end{array}$ & $1,375,568$ & 3,539 & 1.7 & $1.5-1.9$ & 0.11 \\
\hline $18-24$ & $1,725,603$ & 2,279 & 2.2 & $1.8-2.6$ & 0.19 \\
\hline $25-64$ & $14,247,961$ & 23,619 & 2.2 & $2.1-2.3$ & 0.06 \\
\hline $\begin{array}{l}\quad 65 \text { and older } \\
\text { Education }^{2}\end{array}$ & 574,664 & 1,162 & 2.1 & $0.8-3.4$ & 0.68 \\
\hline Less than HS & $1,141,190$ & 2,347 & 2.4 & $2.0-2.8$ & 0.21 \\
\hline High school & $3,582,213$ & 5,951 & 2.3 & $2.0-2.6$ & 0.14 \\
\hline $\begin{array}{l}\text { More than HS } \\
\text { Insurance }\end{array}$ & $11,751,646$ & 18,668 & 2.1 & $2.0-2.2$ & 0.07 \\
\hline Insured & $14,662,946$ & 23,542 & 2.2 & $2.1-2.3$ & 0.06 \\
\hline Uninsured & $1,839,325$ & 3,464 & 2.4 & $2.0-2.8$ & 0.19 \\
\hline
\end{tabular}

Source: Contract Report (March 2010). NORA Morbidity and Disability: The National Health Interview Survey (NHIS) 1997-2007.Department of Epidemiology and Public Health, University of Miami School of Medicine

The estimates from this table are based on a question from the National Health Interview Survey that asked respondents "During the PAST 12 MONTHS ABOUT how many days did illness or injury keep you in bed for more than half the day? (include days while an overnight patient in a hospital)."

1 Sample size from the National Health Interview Survey for the years 1997-2007

${ }^{2}$ Response categories include (1) less than High School graduate, (2) High School graduate or GED, and (3) Some college or higher education. 


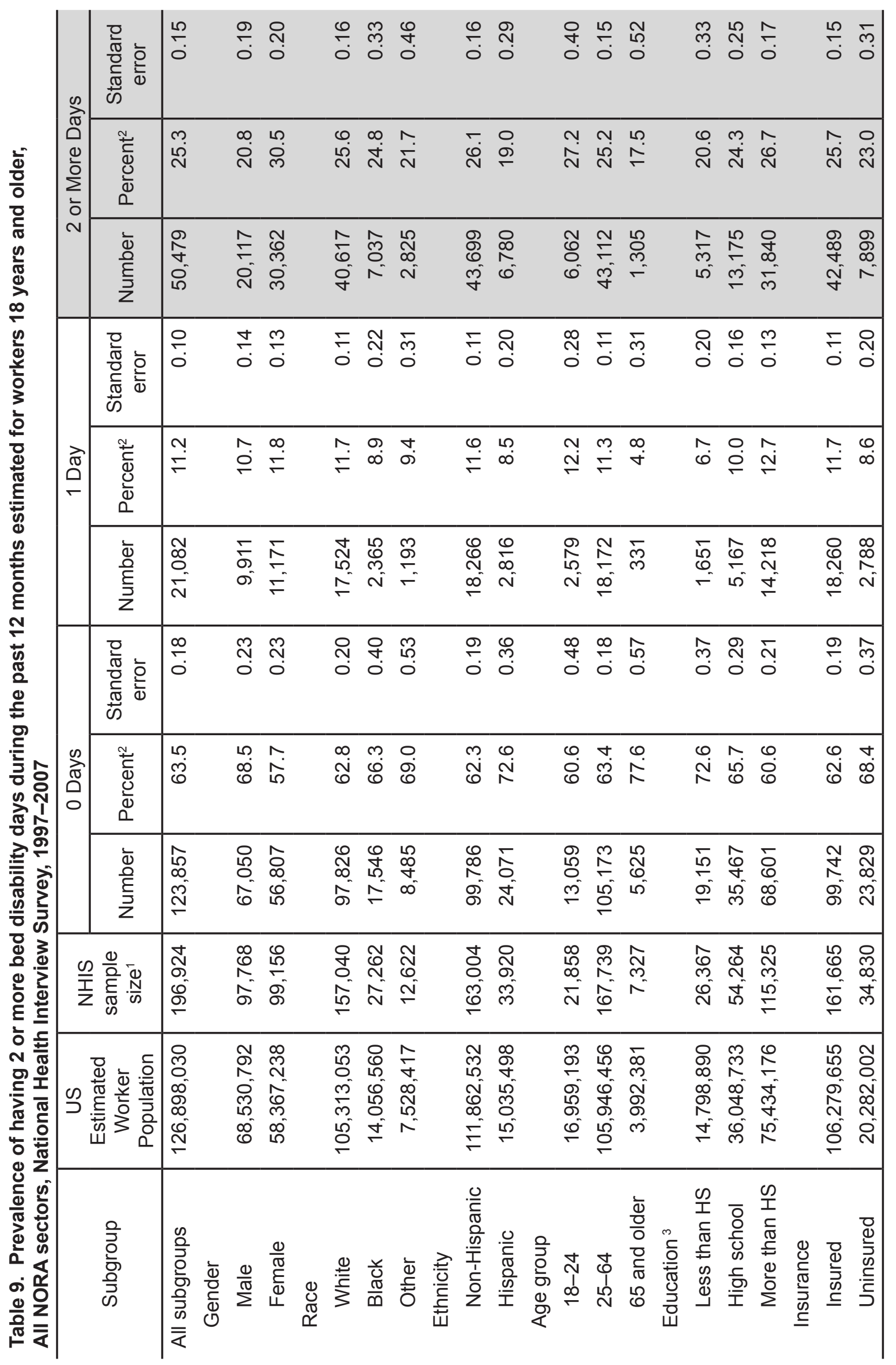

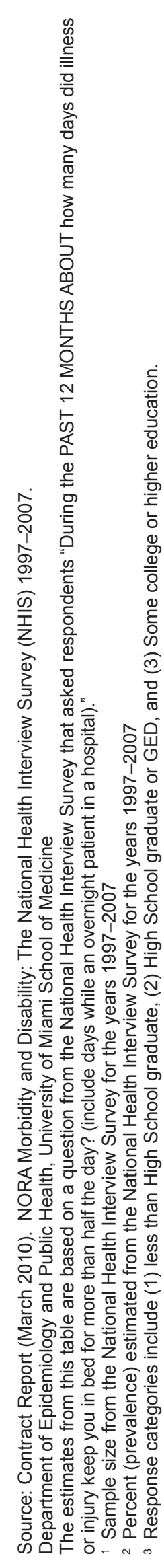




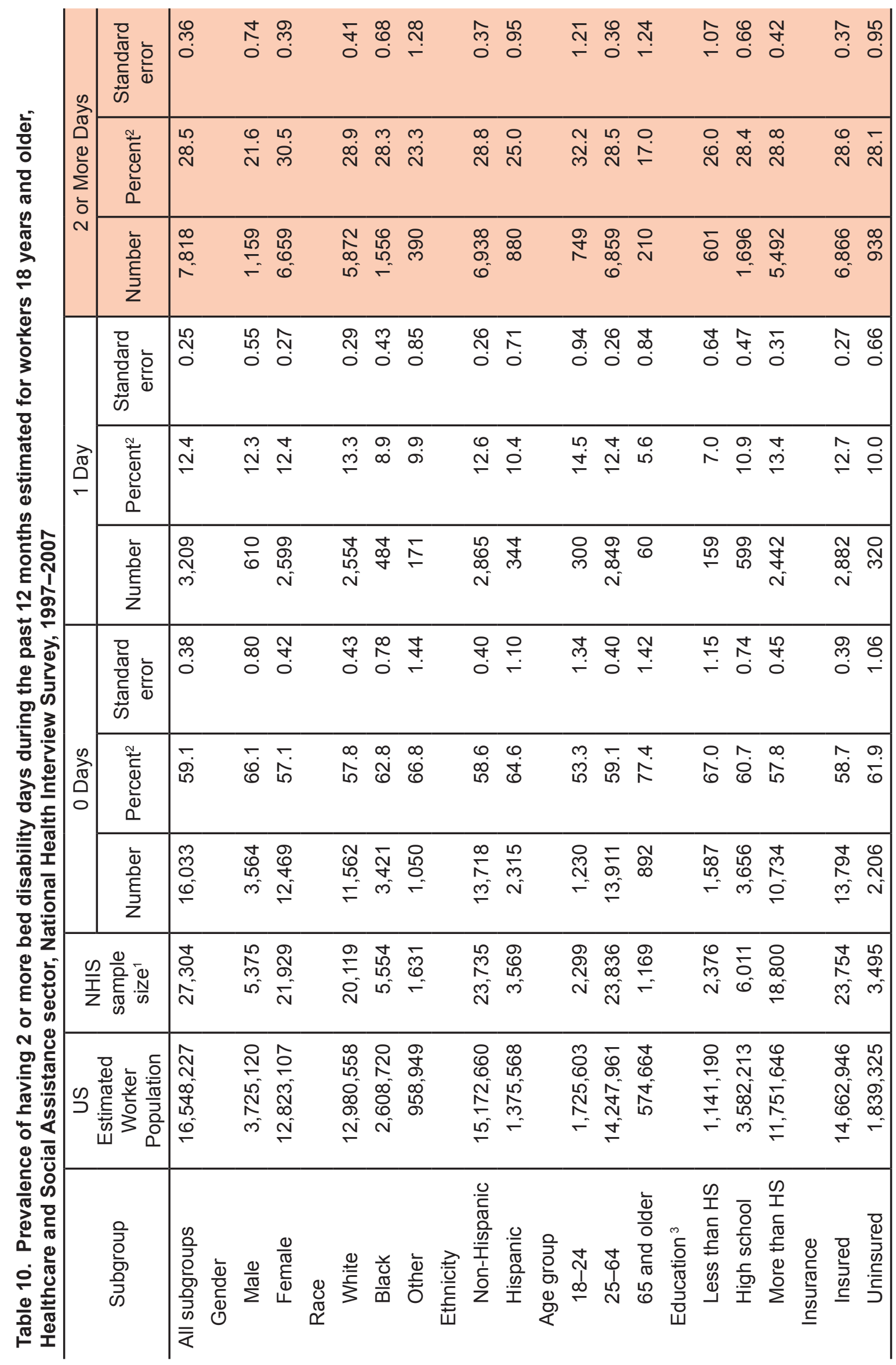

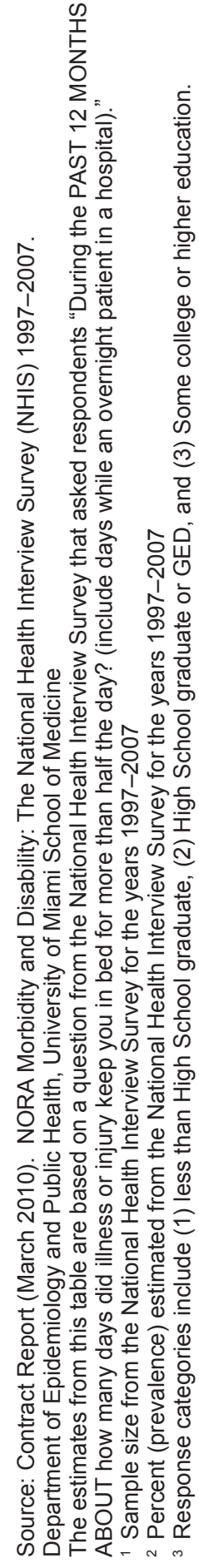


Table 11. Mean number of work loss days during the past 12 months estimated for workers 18 years and older, All NORA sectors, National Health Interview Survey, 1997-2007

\begin{tabular}{|c|c|c|c|c|c|}
\hline Subgroup & $\begin{array}{c}\text { US Estimated } \\
\text { Worker } \\
\text { Population }\end{array}$ & $\begin{array}{l}\text { NHIS sample } \\
\text { size }^{1}\end{array}$ & Mean & $\begin{array}{c}95 \% \\
\text { confidence } \\
\text { interval }\end{array}$ & $\begin{array}{l}\text { Standard } \\
\text { error }\end{array}$ \\
\hline All subgroups & $126,898,030$ & 194,982 & 3.9 & $3.8--4.0$ & 0.04 \\
\hline \multicolumn{6}{|l|}{ Gender } \\
\hline Male & $68,530,792$ & 96,875 & 3.5 & 3.4--3.6 & 0.06 \\
\hline Female & $58,367,238$ & 98,107 & 4.3 & $4.2--4.4$ & 0.06 \\
\hline \multicolumn{6}{|l|}{ Race } \\
\hline White & $105,313,053$ & 155,651 & 3.8 & 3.7--3.9 & 0.05 \\
\hline Black & $14,056,560$ & 26,852 & 4.5 & $4.3--4.7$ & 0.12 \\
\hline Other & $7,528,417$ & 12,479 & 3.4 & $3.1--3.7$ & 0.17 \\
\hline \multicolumn{6}{|l|}{ Ethnicity } \\
\hline Non-Hispanic & $111,862,532$ & 161,408 & 3.9 & $3.8--4.0$ & 0.04 \\
\hline Hispanic & $15,035,498$ & 33,574 & 3.3 & $3.1--3.5$ & 0.10 \\
\hline \multicolumn{6}{|l|}{ Age group } \\
\hline $18-24$ & $16,959,193$ & 21,664 & 3.1 & 2.9--3.3 & 0.10 \\
\hline $25-64$ & $105,946,456$ & 166,104 & 4.0 & 3.9--4.1 & 0.05 \\
\hline 65 and older & $3,992,381$ & 7,214 & 3.6 & $3.2--4.0$ & 0.21 \\
\hline \multicolumn{6}{|l|}{ Education $^{2}$} \\
\hline Less than HS & $14,798,890$ & 26,034 & 4.3 & $4.0--4.6$ & 0.14 \\
\hline High school & $36,048,733$ & 53,655 & 4.4 & $4.2--4.6$ & 0.09 \\
\hline More than HS & $75,434,176$ & 114,480 & 3.5 & 3.4--3.6 & 0.05 \\
\hline \multicolumn{6}{|l|}{ Insurance } \\
\hline Insured & $106,279,655$ & 160,161 & 3.9 & $3.8--4.0$ & 0.05 \\
\hline Uninsured & $20,282,002$ & 34,410 & 3.6 & $3.4--3.8$ & 0.11 \\
\hline
\end{tabular}

Source: Contract Report (March 2010). NORA Morbidity and Disability: The National Health Interview Survey (NHIS) 1997-2007.

Department of Epidemiology and Public Health, University of Miami School of Medicine

The estimates from this table are based on a question from the National Health Interview Survey that asked respondents "During the PAST 12

MONTHS ABOUT how many days did you miss work at a job or business because of illness or injury (do not include matenity leave)?"

1 Sample size from the National Health Interview Survey for the years 1997-2007

2 Response categories include (1) less than High School graduate, (2) High School graduate or GED, and (3) Some college or higher education. 
Table 12. Mean number of work loss days during the past 12 months estimated for workers 18 years and older, Healthcare and Social Assistance sector, National Health Interview Survey, 1997-2007

\begin{tabular}{|c|c|c|c|c|c|}
\hline Subgroup & $\begin{array}{l}\text { US Estimated } \\
\text { Worker } \\
\text { Population }\end{array}$ & $\begin{array}{c}\text { NHIS } \\
\text { sample size }{ }^{1}\end{array}$ & Mean & $\begin{array}{c}95 \% \\
\text { confidence } \\
\text { interval }\end{array}$ & $\begin{array}{l}\text { Standard } \\
\text { error }\end{array}$ \\
\hline All subgroups & $16,548,227$ & 27,002 & 4.2 & $4.0-4.4$ & 0.11 \\
\hline \multicolumn{6}{|l|}{ Gender } \\
\hline Male & $3,725,120$ & 5,324 & 3.2 & $2.8-3.6$ & 0.20 \\
\hline Female & $12,823,107$ & 21,678 & 4.5 & $4.2-4.8$ & 0.13 \\
\hline \multicolumn{6}{|l|}{ Race } \\
\hline White & $12,980,558$ & 19,953 & 4.1 & $3.8-4.4$ & 0.13 \\
\hline Black & $2,608,720$ & 5,440 & 5.1 & $4.6-5.6$ & 0.26 \\
\hline Other & 958,949 & 1,609 & 3.0 & $2.4-3.6$ & 0.29 \\
\hline \multicolumn{6}{|l|}{ Ethnicity } \\
\hline Non-Hispanic & $15,172,660$ & 23,474 & 4.2 & $4.0-4.4$ & 0.12 \\
\hline Hispanic & $1,375,568$ & 3,528 & 3.9 & $3.3-4.5$ & 0.31 \\
\hline \multicolumn{6}{|l|}{ Age group } \\
\hline 18-24 & $1,725,603$ & 2,280 & 3.2 & $2.8-3.6$ & 0.23 \\
\hline $25-64$ & $14,247,961$ & 23,569 & 4.4 & $4.2-4.6$ & 0.12 \\
\hline 65 and older & 574,664 & 1,153 & 3.0 & $2.3-3.7$ & 0.36 \\
\hline \multicolumn{6}{|l|}{ Education $^{2}$} \\
\hline Less than HS & $1,141,190$ & 2,334 & 4.9 & $3.9-5.9$ & 0.49 \\
\hline High school & $3,582,213$ & 5,942 & 4.8 & $4.3-5.3$ & 0.24 \\
\hline More than HS & $11,751,646$ & 18,630 & 4.0 & $3.7-4.3$ & 0.14 \\
\hline \multicolumn{6}{|l|}{ Insurance } \\
\hline Insured & $14,662,946$ & 23,488 & 4.2 & $4.0-4.4$ & 0.12 \\
\hline Uninsured & $1,839,325$ & 3,460 & 4.1 & $3.4-4.8$ & 0.37 \\
\hline
\end{tabular}

Source: Contract Report (March 2010). NORA Morbidity and Disability: The National Health Interview Survey (NHIS) $1997-2007$.

Department of Epidemiology and Public Health, University of Miami School of Medicine

The estimates from this table are based on a question from the National Health Interview Survey that asked respondents "During the PAST 12

MONTHS ABOUT how many days did you miss work at a job or business because of illness or injury (do not include maternity leave)?"

1 Sample size from the National Health Interview Survey for the years 1997-2007

2 Response categories include (1) less than High School graduate, (2) High School graduate or GED, and (3) Some college or higher education. 


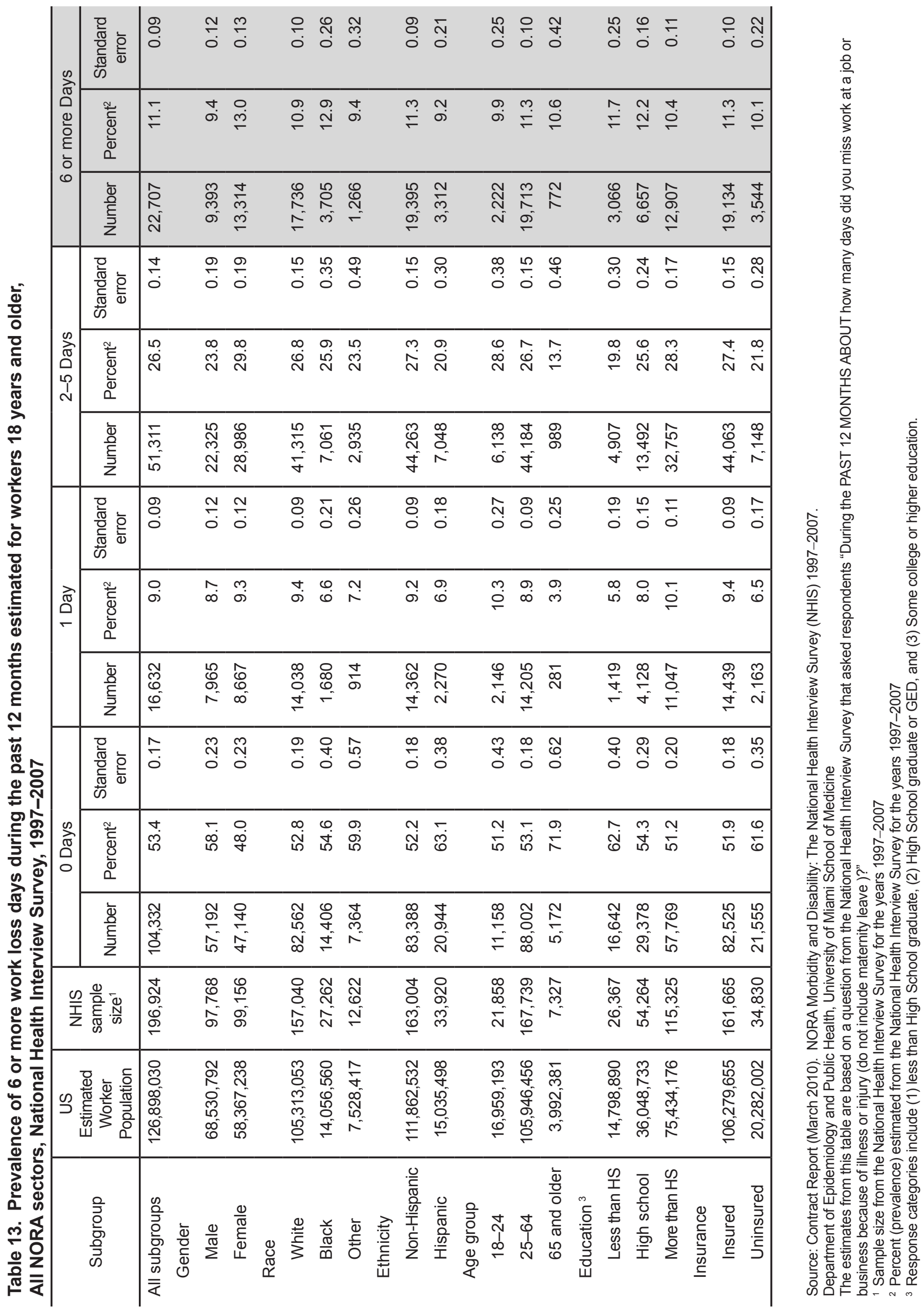




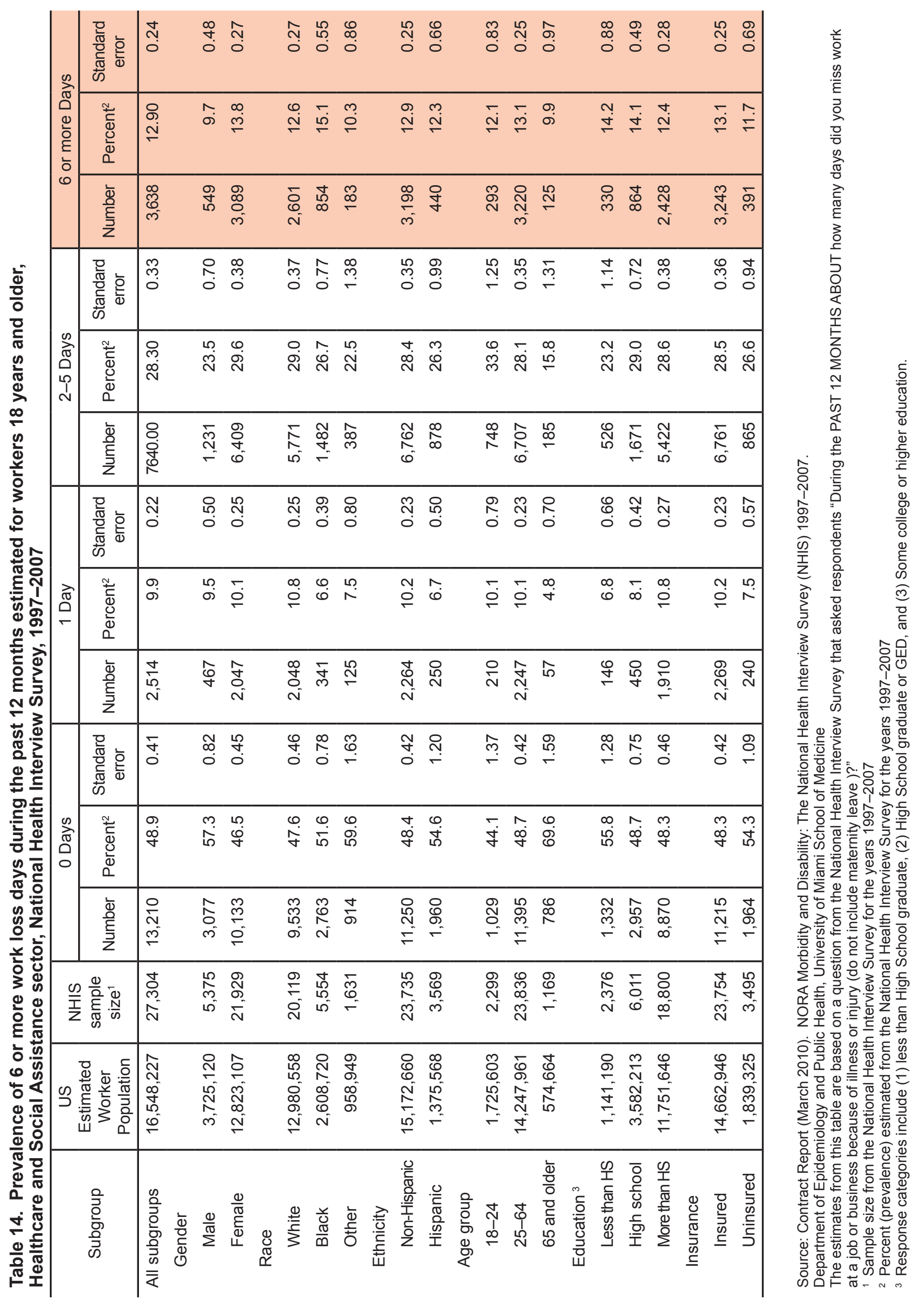


Table 15. Prevalence of health problems requiring the use of special equipment estimated for workers 18 years and older, All NORA sectors, National Health Interview Survey, 1997-2007

\begin{tabular}{|c|c|c|c|c|c|c|c|c|}
\hline \multirow[b]{2}{*}{ Subgroup } & \multirow{2}{*}{$\begin{array}{c}\text { US Estimated } \\
\text { Worker } \\
\text { Population }\end{array}$} & \multirow{2}{*}{$\begin{array}{l}\text { NHIS } \\
\text { sample } \\
\text { size }^{1}\end{array}$} & \multicolumn{3}{|c|}{ No } & \multicolumn{3}{|c|}{ Yes } \\
\hline & & & Number & Percent $^{2}$ & $\begin{array}{c}\text { Standard } \\
\text { error }\end{array}$ & Number & Percent $^{2}$ & $\begin{array}{c}\text { Standarc } \\
\text { error }\end{array}$ \\
\hline $\begin{array}{l}\text { All subgroups } \\
\text { Gender }\end{array}$ & $126,898,030$ & 196,924 & 193,976 & 98.6 & 0.03 & 2,796 & 1.4 & 0.03 \\
\hline Male & $68,530,792$ & 97,768 & 96,261 & 98.5 & 0.05 & 1,420 & 1.5 & 0.05 \\
\hline $\begin{array}{l}\text { Female } \\
\text { Race }\end{array}$ & $58,367,238$ & 99,156 & 97,715 & 98.7 & 0.04 & 1,376 & 1.3 & 0.04 \\
\hline White & $105,313,053$ & 157,040 & 154,619 & 98.6 & 0.04 & 2,302 & 1.4 & 0.04 \\
\hline Black & $14,056,560$ & 27,262 & 26,873 & 98.8 & 0.08 & 367 & 1.2 & 0.08 \\
\hline $\begin{array}{c}\text { Other } \\
\text { Ethnicity }\end{array}$ & $7,528,417$ & 12,622 & 12,484 & 99.0 & 0.10 & 127 & 1.0 & 0.10 \\
\hline Non-Hispanic & $111,862,532$ & 163,004 & 160,366 & 98.6 & 0.04 & 2,516 & 1.4 & 0.04 \\
\hline $\begin{array}{l}\text { Hispanic } \\
\text { Age group }\end{array}$ & $15,035,498$ & 33,920 & 33,610 & 99.1 & 0.07 & 280 & 0.9 & 0.07 \\
\hline $18-24$ & $16,959,193$ & 21,858 & 21,713 & 99.4 & 0.07 & 132 & 0.6 & 0.07 \\
\hline $25-64$ & $105,946,456$ & 167,739 & 165,273 & 98.6 & 0.04 & 2,343 & 1.4 & 0.04 \\
\hline $\begin{array}{l}\quad 65 \text { and older } \\
\text { Education }^{3}\end{array}$ & $3,992,381$ & 7,327 & 6,990 & 95.6 & 0.27 & 321 & 4.4 & 0.27 \\
\hline Less than HS & $14,798,890$ & 26,367 & 26,039 & 98.8 & 0.09 & 302 & 1.2 & 0.09 \\
\hline High school & $36,048,733$ & 54,264 & 53,504 & 98.7 & 0.06 & 710 & 1.3 & 0.06 \\
\hline $\begin{array}{l}\text { More than HS } \\
\text { Insurance }\end{array}$ & $75,434,176$ & 115,325 & 113,492 & 98.6 & 0.04 & 1,765 & 1.4 & 0.04 \\
\hline Insured & $106,279,655$ & 161,665 & 159,074 & 98.5 & 0.04 & 2,470 & 1.5 & 0.04 \\
\hline Uninsured & $20,282,002$ & 34,830 & 34,478 & 99.1 & 0.07 & 321 & 0.9 & 0.07 \\
\hline
\end{tabular}

Source: Contract Report (March 2010). NORA Morbidity and Disability: The National Health Interview Survey (NHIS) 1997-2007. Department of Epidemiology and Public Health, University of Miami School of Medicine

The estimates from this table are based on a question from the National Health Interview Survey that asked respondents "Do you now have any health problem that requires you to use special equipment, such as a cane, a wheelchair, a special bed, or a special telephone?"

1 Sample size from the National Health Interview Survey for the years 1997-2007

${ }_{2}^{2}$ Percent (prevalence) estimated from the National Health Interview Survey for the years 1997-2007

${ }^{3}$ Respondents are asked the question "What is the higest level of education that you have completed. Analysis categories summarize the responses by (1) less than High School graduate, (2) High School graduate or GED, and (3) Some college or higher education. 
Table 16. Prevalence of health problems requiring the use of special equipment estimated for workers 18 years and older, Healthcare and Social Assistance sector, National Health Interview Survey, 1997-2007

\begin{tabular}{|c|c|c|c|c|c|c|c|c|}
\hline \multirow[b]{2}{*}{ Subgroup } & \multirow{2}{*}{$\begin{array}{c}\text { US Estimated } \\
\text { Worker } \\
\text { Population }\end{array}$} & \multirow{2}{*}{$\begin{array}{l}\text { NHIS } \\
\text { sample } \\
\text { size }^{1}\end{array}$} & \multicolumn{3}{|c|}{ No } & \multicolumn{3}{|c|}{ Yes } \\
\hline & & & Number & Percent $^{2}$ & $\begin{array}{l}\text { Standard } \\
\text { error }\end{array}$ & Number & Percent $^{2}$ & $\begin{array}{c}\text { Standard } \\
\text { error }\end{array}$ \\
\hline $\begin{array}{l}\text { All subgroups } \\
\text { Gender }\end{array}$ & $16,548,227$ & 27,304 & 26,867 & 98.6 & 0.09 & 418 & 1.4 & 0.09 \\
\hline Male & $3,725,120$ & 5,375 & 5,262 & 98.2 & 0.19 & 108 & 1.8 & 0.19 \\
\hline $\begin{array}{l}\text { Female } \\
\text { Race }\end{array}$ & $12,823,107$ & 21,929 & 21,605 & 98.6 & 0.09 & 310 & 1.4 & 0.09 \\
\hline White & $12,980,558$ & 20,119 & 19,789 & 98.5 & 0.10 & 317 & 1.5 & 0.10 \\
\hline Black & $2,608,720$ & 5,554 & 5,474 & 98.8 & 0.17 & 76 & 1.2 & 0.17 \\
\hline $\begin{array}{c}\text { Other } \\
\text { Ethnicity }\end{array}$ & 958,949 & 1,631 & 1,604 & 98.6 & 0.33 & 25 & 1.4 & 0.33 \\
\hline Non-Hispanic & $15,172,660$ & 23,735 & 23,335 & 98.5 & 0.09 & 384 & 1.5 & 0.09 \\
\hline $\begin{array}{l}\text { Hispanic } \\
\text { Age group }\end{array}$ & $1,375,568$ & 3,569 & 3,532 & 99.0 & 0.21 & 34 & 1.0 & 0.21 \\
\hline $18-24$ & $1,725,603$ & 2,299 & 2,293 & 99.8 & 0.11 & 6 & 0.2 & 0.11 \\
\hline $25-64$ & $14,247,961$ & 23,836 & 23,457 & 98.5 & 0.09 & 361 & 1.5 & 0.09 \\
\hline $\begin{array}{l}\quad 65 \text { and older } \\
\text { Education }^{3}\end{array}$ & 574,664 & 1,169 & 1,117 & 95.8 & 0.65 & 51 & 4.2 & 0.65 \\
\hline Less than HS & $1,141,190$ & 2,376 & 2,331 & 98.3 & 0.33 & 42 & 1.7 & 0.33 \\
\hline High school & $3,582,213$ & 6,011 & 5,927 & 98.7 & 0.17 & 80 & 1.3 & 0.17 \\
\hline $\begin{array}{l}\text { More than HS } \\
\text { Insurance }\end{array}$ & $11,751,646$ & 18,800 & 18,499 & 98.6 & 0.10 & 290 & 1.4 & 0.10 \\
\hline Insured & $14,662,946$ & 23,754 & 23,362 & 98.5 & 0.09 & 377 & 1.5 & 0.09 \\
\hline Uninsured & $1,839,325$ & 3,495 & 3,450 & 98.8 & 0.23 & 41 & 1.2 & 0.23 \\
\hline
\end{tabular}

Source: Contract Report (March 2010). NORA Morbidity and Disability: The National Health Interview Survey (NHIS) $1997-2007$. Department of Epidemiology and Public Health, University of Miami School of Medicine

The estimates from this table are based on a question from the National Health Interview Survey that asked respondents "Do you now have any health problem that requires you to use special equipment, such as a cane, a wheelchair, a special bed, or a special telephone?"

1 Sample size from the National Health Interview Survey for the years 1997-2007

2 Percent (prevalence) estimated from the National Health Interview Survey for the years 1997-2007

${ }^{3}$ Respondents are asked the question "What is the higest level of education that you have completed. Analysis categories summarize the responses by (1) less than High School graduate, (2) High School graduate or GED, and (3) Some college or higher education. 
Table 17. Prevalence of any functional limitations estimated for workers 18 years and older, All NORA sectors, National Health Interview Survey, 1997-2007

\begin{tabular}{|c|c|c|c|c|c|c|c|c|}
\hline \multirow[b]{2}{*}{ Subgroup } & \multirow{2}{*}{$\begin{array}{c}\text { US } \\
\text { Estimated } \\
\text { Worker } \\
\text { Population }\end{array}$} & \multirow{2}{*}{$\begin{array}{c}\text { NHIS } \\
\text { sample } \\
\text { size }^{1}\end{array}$} & \multicolumn{3}{|c|}{ No } & \multicolumn{3}{|c|}{ Yes } \\
\hline & & & Number & Percent $^{2}$ & $\begin{array}{l}\text { Standard } \\
\text { error }\end{array}$ & Number & Percent ${ }^{2}$ & $\begin{array}{c}\text { Standard } \\
\text { error }\end{array}$ \\
\hline $\begin{array}{l}\text { All subgroups } \\
\text { Gender }\end{array}$ & $126,898,030$ & 196,924 & 153,444 & 78.4 & 0.18 & 43,097 & 21.6 & 0.18 \\
\hline Male & $68,530,792$ & 97,768 & 80,077 & 81.8 & 0.20 & 17,486 & 18.2 & 0.20 \\
\hline $\begin{array}{l}\text { Female } \\
\text { Race }\end{array}$ & $58,367,238$ & 99,156 & 73,367 & 74.4 & 0.23 & 25,611 & 25.6 & 0.23 \\
\hline White & $105,313,053$ & 157,040 & 121,278 & 77.6 & 0.20 & 35,476 & 22.4 & 0.20 \\
\hline Black & $14,056,560$ & 27,262 & 21,703 & 81.1 & 0.31 & 5,496 & 18.9 & 0.31 \\
\hline $\begin{array}{c}\text { Other } \\
\text { Ethnicity }\end{array}$ & $7,528,417$ & 12,622 & 10,463 & 84.1 & 0.45 & 2,125 & 15.9 & 0.45 \\
\hline Non-Hispanic & $111,862,532$ & 163,004 & 124,654 & 77.4 & 0.19 & 38,024 & 22.6 & 0.19 \\
\hline $\begin{array}{l}\text { Hispanic } \\
\text { Age group }\end{array}$ & $15,035,498$ & 33,920 & 28,790 & 85.7 & 0.28 & 5,073 & 14.3 & 0.28 \\
\hline $18-24$ & $16,959,193$ & 21,858 & 19,261 & 88.1 & 0.31 & 2,570 & 11.9 & 0.31 \\
\hline $25-64$ & $105,946,456$ & 167,739 & 130,063 & 77.7 & 0.19 & 37,362 & 22.3 & 0.19 \\
\hline $\begin{array}{l}\quad 65 \text { and older } \\
\text { Education }^{3}\end{array}$ & $3,992,381$ & 7,327 & 4,120 & 56.3 & 0.70 & 3,165 & 43.7 & 0.70 \\
\hline Less than HS & $14,798,890$ & 26,367 & 20,694 & 78.2 & 0.39 & 5,616 & 21.8 & 0.39 \\
\hline High school & $36,048,733$ & 54,264 & 41,449 & 76.8 & 0.25 & 12,698 & 23.2 & 0.25 \\
\hline $\begin{array}{l}\text { More than HS } \\
\text { Insurance }\end{array}$ & $75,434,176$ & 115,325 & 90,523 & 79.2 & 0.20 & 24,613 & 20.8 & 0.20 \\
\hline Insured & $106,279,655$ & 161,665 & 124,931 & 77.9 & 0.18 & 36,414 & 22.1 & 0.18 \\
\hline Uninsured & $20,282,002$ & 34,830 & 28,153 & 80.9 & 0.34 & 6,614 & 19.1 & 0.34 \\
\hline
\end{tabular}

Source: Contract Report (March 2010). NORA Morbidity and Disability: The National Health Interview Survey (NHIS) 1997-2007. Department of Epidemiology and Public Health, University of Miami School of Medicine

The estimates from this table are based on a question from the National Health Interview Survey that asked respondents Information on activity limitations. "How difficult it is for you to walk $1 / 4$ mile w/out special equipment; climb 10 steps w/o special equipment; stand 2 hours w/o special equipment; Sit 2 hours w/o special equipmentstoop, bend or kneel w/o special equipment; reach over w/o special equipment; grasp small objects w/o special equipment; lift/carry $10 \mathrm{lbs}$ w/o special equipment; push large objects w/o special equipment; go out to events w/o special equipment; participate in social activities w/o special equipment; or relax at home w/o special equipment?"

1 Sample size from the National Health Interview Survey for the years 1997-2007

2 Percent (prevalence) estimated from the National Health Interview Survey for the years 1997-2007

${ }^{3}$ Respondents are asked the question "What is the higest level of education that you have completed. Analysis categories summarize the responses by (1) less than High School graduate, (2) High School graduate or GED, and (3) Some college or higher education. 
Table 18. Prevalence of any functional limitations estimated for workers 18 years and older, Healthcare and Social Assistance sector, National Health Interview Survey, 1997-2007

\begin{tabular}{|c|c|c|c|c|c|c|c|c|}
\hline \multirow[b]{2}{*}{ Subgroup } & \multirow{2}{*}{$\begin{array}{c}\text { US } \\
\text { Estimated } \\
\text { Worker } \\
\text { Population }\end{array}$} & \multirow{2}{*}{$\begin{array}{c}\text { NHIS } \\
\text { sample } \\
\text { size }^{1}\end{array}$} & \multicolumn{3}{|c|}{ No } & \multicolumn{3}{|c|}{ Yes } \\
\hline & & & Number & Percent $^{2}$ & $\begin{array}{l}\text { Standard } \\
\text { error }\end{array}$ & Number & Percent $^{2}$ & $\begin{array}{c}\text { Standard } \\
\text { error }\end{array}$ \\
\hline $\begin{array}{l}\text { All subgroups } \\
\text { Gender }\end{array}$ & $16,548,227$ & 27,304 & 20,255 & 74.9 & 0.34 & 7,006 & 25.1 & 0.34 \\
\hline Male & $3,725,120$ & 5,375 & 4,364 & 81.9 & 0.63 & 1,001 & 18.1 & 0.63 \\
\hline $\begin{array}{l}\text { Female } \\
\text { Race }\end{array}$ & $12,823,107$ & 21,929 & 15,891 & 72.9 & 0.37 & 6,005 & 27.1 & 0.37 \\
\hline White & $12,980,558$ & 20,119 & 14,771 & 74.2 & 0.39 & 5,320 & 25.8 & 0.39 \\
\hline Black & $2,608,720$ & 5,554 & 4,194 & 76.9 & 0.65 & 1,350 & 23.1 & 0.65 \\
\hline $\begin{array}{c}\text { Other } \\
\text { Ethnicity }\end{array}$ & 958,949 & 1,631 & 1,290 & 80.2 & 1.22 & 336 & 19.8 & 1.22 \\
\hline Non-Hispanic & $15,172,660$ & 23,735 & 17,471 & 74.7 & 0.36 & 6,226 & 25.3 & 0.36 \\
\hline $\begin{array}{l}\text { Hispanic } \\
\text { Age group }\end{array}$ & $1,375,568$ & 3,569 & 2,784 & 77.7 & 0.91 & 780 & 22.3 & 0.91 \\
\hline $18-24$ & $1,725,603$ & 2,299 & 1,987 & 86.3 & 0.90 & 307 & 13.7 & 0.90 \\
\hline $25-64$ & $14,247,961$ & 23,836 & 17,646 & 74.4 & 0.36 & 6,158 & 25.6 & 0.36 \\
\hline $\begin{array}{l}\quad 65 \text { and older } \\
\text { Education }^{3}\end{array}$ & 574,664 & 1,169 & 622 & 53.6 & 1.83 & 541 & 46.4 & 1.83 \\
\hline Less than HS & $1,141,190$ & 2,376 & 1,595 & 66.4 & 1.23 & 778 & 33.6 & 1.23 \\
\hline High school & $3,582,213$ & 6,011 & 4,269 & 71.0 & 0.70 & 1,734 & 29.0 & 0.70 \\
\hline $\begin{array}{l}\text { More than HS } \\
\text { Insurance }\end{array}$ & $11,751,646$ & 18,800 & 14,313 & 77.0 & 0.38 & 4,458 & 23.0 & 0.38 \\
\hline Insured & $14,662,946$ & 23,754 & 17,656 & 75.1 & 0.36 & 6,061 & 24.9 & 0.36 \\
\hline Uninsured & $1,839,325$ & 3,495 & 2,552 & 73.5 & 0.90 & 937 & 26.5 & 0.90 \\
\hline
\end{tabular}

Source: Contract Report (March 2010). NORA Morbidity and Disability: The National Health Interview Survey (NHIS) $1997-2007$. Department of Epidemiology and Public Health, University of Miami School of Medicine

The estimates from this table are based on a question from the National Health Interview Survey that asked respondents Information on activity limitations. "How difficult it is for you to walk $1 / 4$ mile w/out special equipment; climb 10 steps w/o special equipment; stand 2 hours w/o special equipment; Sit 2 hours w/o special equipmentstoop, bend or kneel w/o special equipment; reach over w/o special equipment; grasp small objects w/o special equipment; lift/carry $10 \mathrm{lbs}$ w/o special equipment; push large objects w/o special equipment; go out to events w/o special equipment; participate in social activities w/o special equipment; or relax at home w/o special equipment?"

1 Sample size from the National Health Interview Survey for the years 1997-2007

2 Percent (prevalence) estimated from the National Health Interview Survey for the years 1997-2007

${ }^{3}$ Respondents are asked the question "What is the higest level of education that you have completed. Analysis categories summarize the responses by (1) less than High School graduate, (2) High School graduate or GED, and (3) Some college or higher education. 
Table 19. Prevalence of hearing difficulty estimated for workers 18 years and older, All NORA sectors, National Health Interview Survey, 1997-2007

\begin{tabular}{|c|c|c|c|c|c|c|c|c|}
\hline \multirow[b]{2}{*}{ Subgroup } & \multirow{2}{*}{$\begin{array}{c}\text { US } \\
\text { Estimated } \\
\text { Worker } \\
\text { Population }\end{array}$} & \multirow{2}{*}{$\begin{array}{c}\text { NHIS } \\
\text { sample } \\
\text { size }^{1}\end{array}$} & \multicolumn{3}{|c|}{ No } & \multicolumn{3}{|c|}{ Yes } \\
\hline & & & Number & Percent $^{2}$ & $\begin{array}{l}\text { Standard } \\
\text { error }\end{array}$ & Number & Percent $^{2}$ & $\begin{array}{c}\text { Standard } \\
\text { error }\end{array}$ \\
\hline $\begin{array}{l}\text { All subgroups } \\
\text { Gender }\end{array}$ & $126,898,030$ & 196,924 & 174,139 & 88.0 & 0.12 & 22,726 & 12.0 & 0.12 \\
\hline Male & $68,530,792$ & 97,768 & 83,911 & 85.4 & 0.17 & 13,833 & 14.6 & 0.17 \\
\hline $\begin{array}{l}\text { Female } \\
\text { Race }\end{array}$ & $58,367,238$ & 99,156 & 90,228 & 91.0 & 0.13 & 8,893 & 9.0 & 0.13 \\
\hline White & $105,313,053$ & 157,040 & 136,854 & 86.8 & 0.14 & 20,136 & 13.2 & 0.14 \\
\hline Black & $14,056,560$ & 27,262 & 25,647 & 94.4 & 0.17 & 1,609 & 5.6 & 0.17 \\
\hline $\begin{array}{l}\text { Other } \\
\text { Ethnicity }\end{array}$ & $7,528,417$ & 12,622 & 11,638 & 92.3 & 0.32 & 981 & 7.7 & 0.32 \\
\hline Non-Hispanic & $111,862,532$ & 163,004 & 142,305 & 87.2 & 0.14 & 20,646 & 12.8 & 0.14 \\
\hline $\begin{array}{l}\text { Hispanic } \\
\text { Age group }\end{array}$ & $15,035,498$ & 33,920 & 31,834 & 93.9 & 0.17 & 2,080 & 6.1 & 0.17 \\
\hline $18-24$ & $16,959,193$ & 21,858 & 20,603 & 94.2 & 0.20 & 1,250 & 5.8 & 0.20 \\
\hline $25-64$ & $105,946,456$ & 167,739 & 148,440 & 87.7 & 0.13 & 19,250 & 12.3 & 0.13 \\
\hline $\begin{array}{l}\quad 65 \text { and older } \\
\text { Education }^{3}\end{array}$ & $3,992,381$ & 7,327 & 5,096 & 67.2 & 0.66 & 2,226 & 32.8 & 0.66 \\
\hline Less than HS & $14,798,890$ & 26,367 & 23,552 & 88.2 & 0.27 & 2,809 & 11.8 & 0.27 \\
\hline High school & $36,048,733$ & 54,264 & 47,221 & 86.5 & 0.20 & 7,028 & 13.5 & 0.20 \\
\hline $\begin{array}{l}\text { More than HS } \\
\text { Insurance }\end{array}$ & $75,434,176$ & 115,325 & 102,518 & 88.6 & 0.14 & 12,776 & 11.4 & 0.14 \\
\hline Insured & $106,279,655$ & 161,665 & 142,257 & 87.6 & 0.13 & 19,357 & 12.4 & 0.13 \\
\hline Uninsured & $20,282,002$ & 34,830 & 31,504 & 89.9 & 0.23 & 3,319 & 10.1 & 0.23 \\
\hline
\end{tabular}

Source: Contract Report (March 2010). NORA Morbidity and Disability: The National Health Interview Survey (NHIS) $1997-2007$. Department of Epidemiology and Public Health, University of Miami School of Medicine

The estimates from this table are based on questions from the National Health Interview Survey that asked respondents "Which

statement best describes your hearing (without a hearing aid): good, a little trouble, a lot of trouble, deaf?"

1 Sample size from the National Health Interview Survey for the years 1997-2007

${ }^{2}$ Percent (prevalence) estimated from the National Health Interview Survey for the years 1997-2007

${ }^{3}$ Response categories include (1) less than High School graduate, (2) High School graduate or GED, and (3) Some college or higher education. 
Table 20. Prevalence of hearing difficulty estimated for workers 18 years and older, Healthcare and Social Assistance sector, National Health Interview Survey, 1997-2007

\begin{tabular}{|c|c|c|c|c|c|c|c|c|}
\hline \multirow[b]{2}{*}{ Subgroup } & \multirow{2}{*}{$\begin{array}{c}\text { US } \\
\text { Estimated } \\
\text { Worker } \\
\text { Population }\end{array}$} & \multirow{2}{*}{$\begin{array}{c}\text { NHIS } \\
\text { sample } \\
\text { size }^{1}\end{array}$} & \multicolumn{3}{|c|}{ No } & \multicolumn{3}{|c|}{ Yes } \\
\hline & & & Number & Percent $^{2}$ & $\begin{array}{c}\text { Standard } \\
\text { error }\end{array}$ & Number & Percent $^{2}$ & $\begin{array}{c}\text { Standard } \\
\text { error }\end{array}$ \\
\hline $\begin{array}{l}\text { All subgroups } \\
\text { Gender }\end{array}$ & $16,548,227$ & 27,304 & 24,637 & 90.1 & 0.21 & 2,661 & 9.9 & 0.21 \\
\hline Male & $3,725,120$ & 5,375 & 4,671 & 86.9 & 0.51 & 703 & 13.1 & 0.51 \\
\hline $\begin{array}{l}\text { Female } \\
\text { Race }\end{array}$ & $12,823,107$ & 21,929 & 19,966 & 91.1 & 0.22 & 1,958 & 8.9 & 0.22 \\
\hline White & $12,980,558$ & 20,119 & 17,866 & 89.0 & 0.25 & 2,248 & 11.0 & 0.25 \\
\hline Black & $2,608,720$ & 5,554 & 5,250 & 94.7 & 0.38 & 303 & 5.3 & 0.38 \\
\hline $\begin{array}{c}\text { Other } \\
\text { Ethnicity }\end{array}$ & 958,949 & 1,631 & 1,521 & 93.6 & 0.75 & 110 & 6.4 & 0.75 \\
\hline Non-Hispanic & $15,172,660$ & 23,735 & 21,315 & 89.8 & 0.22 & 2,414 & 10.2 & 0.22 \\
\hline $\begin{array}{l}\text { Hispanic } \\
\text { Age group }\end{array}$ & $1,375,568$ & 3,569 & 3,322 & 93.4 & 0.52 & 247 & 6.6 & 0.52 \\
\hline $18-24$ & $1,725,603$ & 2,299 & 2,197 & 95.0 & 0.55 & 101 & 5.0 & 0.55 \\
\hline $25-64$ & $14,247,961$ & 23,836 & 21,584 & 90.3 & 0.22 & 2,247 & 9.7 & 0.22 \\
\hline $\begin{array}{l}\quad 65 \text { and older } \\
\text { Education }^{3}\end{array}$ & 574,664 & 1,169 & 856 & 70.6 & 1.50 & 313 & 29.4 & 1.50 \\
\hline Less than HS & $1,141,190$ & 2,376 & 2,149 & 90.4 & 0.72 & 226 & 9.6 & 0.72 \\
\hline High school & $3,582,213$ & 6,011 & 5,385 & 89.4 & 0.45 & 624 & 10.6 & 0.45 \\
\hline $\begin{array}{l}\text { More than HS } \\
\text { Insurance }\end{array}$ & $11,751,646$ & 18,800 & 17,004 & 90.4 & 0.25 & 1,794 & 9.6 & 0.25 \\
\hline Insured & $14,662,946$ & 23,754 & 21,426 & 90.1 & 0.22 & 2,322 & 9.9 & 0.22 \\
\hline Uninsured & $1,839,325$ & 3,495 & 3,156 & 89.8 & 0.62 & 339 & 10.2 & 0.62 \\
\hline
\end{tabular}

Source: Contract Report (March 2010). NORA Morbidity and Disability: The National Health Interview Survey (NHIS) $1997-2007$. Department of Epidemiology and Public Health, University of Miami School of Medicine

The estimates from this table are based on questions from the National Health Interview Survey that asked respondents "Which statement best describes your hearing (without a hearing aid): good, a little trouble, a lot of trouble, deaf?"

1 Sample size from the National Health Interview Survey for the years 1997-2007

2 Percent (prevalence) estimated from the National Health Interview Survey for the years 1997-2007

${ }^{3}$ Response categories include (1) less than High School graduate, (2) High School graduate or GED, and (3) Some college or higher education. 
Table 21. Prevalence of visual impairment estimated for workers 18 years and older, All NORA sectors, National Health Interview Survey, 1997-2007

\begin{tabular}{|c|c|c|c|c|c|c|c|c|}
\hline \multirow[b]{2}{*}{ Subgroup } & \multirow{2}{*}{$\begin{array}{c}\text { US } \\
\text { Estimated } \\
\text { Worker } \\
\text { Population }\end{array}$} & \multirow{2}{*}{$\begin{array}{l}\text { NHIS } \\
\text { sample } \\
\text { size }^{1}\end{array}$} & \multicolumn{3}{|c|}{ No } & \multicolumn{3}{|c|}{ Yes } \\
\hline & & & Number & Percent $^{2}$ & $\begin{array}{l}\text { Standard } \\
\text { error }\end{array}$ & Number & Percent $^{2}$ & $\begin{array}{c}\text { Standard } \\
\text { error }\end{array}$ \\
\hline $\begin{array}{l}\text { All subgroups } \\
\text { Gender }\end{array}$ & $126,898,030$ & 196,924 & 183,289 & 93.3 & 0.09 & 13,537 & 6.7 & 0.09 \\
\hline Male & $68,530,792$ & 97,768 & 92,232 & 94.5 & 0.10 & 5,496 & 5.5 & 0.10 \\
\hline $\begin{array}{l}\text { Female } \\
\text { Race }\end{array}$ & $58,367,238$ & 99,156 & 91,057 & 92.0 & 0.12 & 8,041 & 8.0 & 0.12 \\
\hline White & $105,313,053$ & 157,040 & 146,208 & 93.3 & 0.09 & 10,754 & 6.7 & 0.09 \\
\hline Black & $14,056,560$ & 27,262 & 25,255 & 93.1 & 0.19 & 1,990 & 6.9 & 0.19 \\
\hline $\begin{array}{c}\text { Other } \\
\text { Ethnicity }\end{array}$ & $7,528,417$ & 12,622 & 11,826 & 94.4 & 0.27 & 793 & 5.6 & 0.27 \\
\hline Non-Hispanic & $111,862,532$ & 163,004 & 151,389 & 93.2 & 0.09 & 11,530 & 6.8 & 0.09 \\
\hline $\begin{array}{l}\text { Hispanic } \\
\text { Age group }\end{array}$ & $15,035,498$ & 33,920 & 31,900 & 94.3 & 0.18 & 2,007 & 5.7 & 0.18 \\
\hline $18-24$ & $16,959,193$ & 21,858 & 20,698 & 95.0 & 0.19 & 1,150 & 5.0 & 0.19 \\
\hline $25-64$ & $105,946,456$ & 167,739 & 156,005 & 93.2 & 0.09 & 11,654 & 6.8 & 0.09 \\
\hline $\begin{array}{l}\quad 65 \text { and older } \\
\text { Education }^{3}\end{array}$ & $3,992,381$ & 7,327 & 6,586 & 90.0 & 0.42 & 733 & 10.0 & 0.42 \\
\hline Less than HS & $14,798,890$ & 26,367 & 24,367 & 92.4 & 0.22 & 1,986 & 7.6 & 0.22 \\
\hline High school & $36,048,733$ & 54,264 & 50,331 & 93.0 & 0.14 & 3,904 & 7.0 & 0.14 \\
\hline $\begin{array}{l}\text { More than HS } \\
\text { Insurance }\end{array}$ & $75,434,176$ & 115,325 & 107,692 & 93.7 & 0.10 & 7,589 & 6.3 & 0.10 \\
\hline Insured & $106,279,655$ & 161,665 & 150,810 & 93.6 & 0.09 & 10,776 & 6.4 & 0.09 \\
\hline Uninsured & $20,282,002$ & 34,830 & 32,082 & 92.2 & 0.20 & 2,730 & 7.8 & 0.20 \\
\hline
\end{tabular}

Source: Contract Report (March 2010). NORA Morbidity and Disability: The National Health Interview Survey (NHIS) $1997-2007$. Department of Epidemiology and Public Health, University of Miami School of Medicine

The estimates from this table are based on questions from the National Health Interview Survey that asked respondents "Do you

have trouble seeing, even when wearing glasses or contact lenses?; and, Are you blind or unable to see at all?"

1 Sample size from the National Health Interview Survey for the years 1997-2007

2 Percent (prevalence) estimated from the National Health Interview Survey for the years 1997-2007

${ }^{3}$ Response categories include (1) less than High School graduate, (2) High School graduate or GED, and (3) Some college or higher education. 
Table 22. Prevalence of visual impairment estimated for workers 18 years and older, Healthcare and Social Assistance sector, National Health Interview Survey, 1997-2007

\begin{tabular}{|c|c|c|c|c|c|c|c|c|}
\hline \multirow[b]{2}{*}{ Subgroup } & \multirow{2}{*}{$\begin{array}{c}\text { US } \\
\text { Estimated } \\
\text { Worker } \\
\text { Population }\end{array}$} & \multirow{2}{*}{$\begin{array}{l}\text { NHIS } \\
\text { sample } \\
\text { size }^{1}\end{array}$} & \multicolumn{3}{|c|}{ No } & \multicolumn{3}{|c|}{ Yes } \\
\hline & & & Number & Percent $^{2}$ & $\begin{array}{l}\text { Standard } \\
\text { error }\end{array}$ & Number & Percent $^{2}$ & $\begin{array}{c}\text { Standard } \\
\text { error }\end{array}$ \\
\hline $\begin{array}{l}\text { All subgroups } \\
\text { Gender }\end{array}$ & $16,548,227$ & 27,304 & 25,126 & 92.3 & 0.22 & 2,166 & 7.7 & 0.22 \\
\hline Male & $3,725,120$ & 5,375 & 5,047 & 94.2 & 0.37 & 327 & 5.8 & 0.37 \\
\hline $\begin{array}{l}\text { Female } \\
\text { Race }\end{array}$ & $12,823,107$ & 21,929 & 20,079 & 91.7 & 0.24 & 1,839 & 8.3 & 0.24 \\
\hline White & $12,980,558$ & 20,119 & 18,515 & 92.2 & 0.25 & 1,596 & 7.8 & 0.25 \\
\hline Black & $2,608,720$ & 5,554 & 5,088 & 91.8 & 0.46 & 462 & 8.2 & 0.46 \\
\hline $\begin{array}{c}\text { Other } \\
\text { Ethnicity }\end{array}$ & 958,949 & 1,631 & 1,523 & 94.8 & 0.56 & 108 & 5.2 & 0.56 \\
\hline Non-Hispanic & $15,172,660$ & 23,735 & 21,850 & 92.3 & 0.23 & 1,873 & 7.7 & 0.23 \\
\hline $\begin{array}{l}\text { Hispanic } \\
\text { Age group }\end{array}$ & $1,375,568$ & 3,569 & 3,276 & 91.7 & 0.63 & 293 & 8.3 & 0.63 \\
\hline $18-24$ & $1,725,603$ & 2,299 & 2,145 & 93.7 & 0.62 & 152 & 6.3 & 0.62 \\
\hline $25-64$ & $14,247,961$ & 23,836 & 21,944 & 92.2 & 0.23 & 1,882 & 7.8 & 0.23 \\
\hline $\begin{array}{l}\quad 65 \text { and older } \\
\text { Education }^{3}\end{array}$ & 574,664 & 1,169 & 1,037 & 89.0 & 1.04 & 132 & 11.0 & 1.04 \\
\hline Less than HS & $1,141,190$ & 2,376 & 2,127 & 88.9 & 0.84 & 249 & 11.1 & 0.84 \\
\hline High school & $3,582,213$ & 6,011 & 5,486 & 91.3 & 0.43 & 523 & 8.7 & 0.43 \\
\hline $\begin{array}{l}\text { More than HS } \\
\text { Insurance }\end{array}$ & $11,751,646$ & 18,800 & 17,413 & 92.9 & 0.24 & 1,379 & 7.1 & 0.24 \\
\hline Insured & $14,662,946$ & 23,754 & 21,962 & 92.7 & 0.22 & 1,780 & 7.3 & 0.22 \\
\hline Uninsured & $1,839,325$ & 3,495 & 3,112 & 88.8 & 0.67 & 383 & 11.2 & 0.67 \\
\hline
\end{tabular}

Source: Contract Report (March 2010). NORA Morbidity and Disability: The National Health Interview Survey (NHIS) $1997-2007$. Department of Epidemiology and Public Health, University of Miami School of Medicine

The estimates from this table are based on questions from the National Health Interview Survey that asked respondents "Do you have trouble seeing, even when wearing glasses or contact lenses?; and, Are you blind or unable to see at all?"

1 Sample size from the National Health Interview Survey for the years 1997-2007

2 Percent (prevalence) estimated from the National Health Interview Survey for the years 1997-2007

3 Response categories include (1) less than High School graduate, (2) High School graduate or GED, and (3) Some college or higher education. 
Table 23. Prevalence of cancer estimated for workers 18 years and older, All NORA sectors, National Health Interview Survey, 1997-2007

\begin{tabular}{|c|c|c|c|c|c|c|c|c|}
\hline \multirow[b]{2}{*}{ Subgroup } & \multirow{2}{*}{$\begin{array}{l}\text { US } \\
\text { Estimated } \\
\text { Worker } \\
\text { Population }\end{array}$} & \multirow{2}{*}{$\begin{array}{l}\text { NHIS } \\
\text { sample } \\
\text { size }^{1}\end{array}$} & \multicolumn{3}{|c|}{ No } & \multicolumn{3}{|c|}{ Yes } \\
\hline & & & Number & Percent $^{2}$ & $\begin{array}{l}\text { Standard } \\
\text { error }\end{array}$ & Number & Percent $^{2}$ & $\begin{array}{l}\text { Standard } \\
\text { error }\end{array}$ \\
\hline $\begin{array}{l}\text { All subgroups } \\
\text { Gender }\end{array}$ & $126,898,030$ & 196,924 & 188,905 & 96.0 & 0.05 & 7,897 & 4.0 & 0.05 \\
\hline Male & $68,530,792$ & 97,768 & 94,776 & 96.9 & 0.07 & 2,937 & 3.1 & 0.07 \\
\hline $\begin{array}{l}\text { Female } \\
\text { Race }\end{array}$ & $58,367,238$ & 99,156 & 94,129 & 95.0 & 0.09 & 4,960 & 5.0 & 0.09 \\
\hline White & $105,313,053$ & 157,040 & 149,793 & 95.6 & 0.06 & 7,152 & 4.4 & 0.06 \\
\hline Black & $14,056,560$ & 27,262 & 26,707 & 98.2 & 0.10 & 539 & 1.8 & 0.10 \\
\hline $\begin{array}{l}\text { Other } \\
\text { Ethnicity }\end{array}$ & $7,528,417$ & 12,622 & 12,405 & 98.5 & 0.13 & 206 & 1.5 & 0.13 \\
\hline Non-Hispanic & $111,862,532$ & 163,004 & 155,476 & 95.7 & 0.06 & 7,418 & 4.3 & 0.06 \\
\hline $\begin{array}{l}\text { Hispanic } \\
\text { Age group }\end{array}$ & $15,035,498$ & 33,920 & 33,429 & 98.7 & 0.07 & 479 & 1.3 & 0.07 \\
\hline 18-24 & $16,959,193$ & 21,858 & 21,640 & 99.1 & 0.07 & 210 & 0.9 & 0.07 \\
\hline $25-64$ & $105,946,456$ & 167,739 & 161,134 & 96.0 & 0.06 & 6,501 & 4.0 & 0.06 \\
\hline $\begin{array}{l}\quad 65 \text { and older } \\
\text { Education }^{3}\end{array}$ & $3,992,381$ & 7,327 & 6,131 & 82.9 & 0.53 & 1,186 & 17.1 & 0.53 \\
\hline Less than HS & $14,798,890$ & 26,367 & 25,636 & 97.3 & 0.12 & 714 & 2.7 & 0.12 \\
\hline High school & $36,048,733$ & 54,264 & 52,115 & 96.2 & 0.10 & 2,118 & 3.8 & 0.10 \\
\hline $\begin{array}{l}\text { More than HS } \\
\text { Insurance }\end{array}$ & $75,434,176$ & 115,325 & 110,215 & 95.7 & 0.07 & 5,041 & 4.3 & 0.07 \\
\hline Insured & $106,279,655$ & 161,665 & 154,453 & 95.7 & 0.06 & 7,112 & 4.3 & 0.06 \\
\hline Uninsured & $20,282,002$ & 34,830 & 34,028 & 97.8 & 0.09 & 780 & 2.2 & 0.09 \\
\hline
\end{tabular}

Source: Contract Report (March 2010). NORA Morbidity and Disability: The National Health Interview Survey (NHIS) $1997-2007$. Department of Epidemiology and Public Health, University of Miami School of Medicine

The estimates from this table are based on a question from the National Health Interview Survey that asked respondents "Have you EVER been told by a doctor or other health professional that you had cancer or a malignancy of any kind? "

1 Sample size from the National Health Interview Survey for the years 1997-2007

2 Percent (prevalence) estimated from the National Health Interview Survey for the years 1997-2007

${ }_{3}$ Response categories include (1) less than High School graduate, (2) High School graduate or GED, and (3) Some college or higher education. 
Table 24. Prevalence of cancer estimated for workers 18 years and older, Healthcare and Social Assistance sector, National Health Interview Survey, 1997-2007

\begin{tabular}{|c|c|c|c|c|c|c|c|c|}
\hline \multirow[b]{2}{*}{ Subgroup } & \multirow{2}{*}{$\begin{array}{l}\text { US } \\
\text { Estimated } \\
\text { Worker } \\
\text { Population }\end{array}$} & \multirow{2}{*}{$\begin{array}{c}\text { NHIS } \\
\text { sample } \\
\text { size }^{1}\end{array}$} & \multicolumn{3}{|c|}{ No } & \multicolumn{3}{|c|}{ Yes } \\
\hline & & & Number & Percent $^{2}$ & $\begin{array}{l}\text { Standard } \\
\text { error }\end{array}$ & Number & Percent ${ }^{2}$ & $\begin{array}{c}\text { Standard } \\
\text { error }\end{array}$ \\
\hline $\begin{array}{l}\text { All subgroups } \\
\text { Gender }\end{array}$ & $16,548,227$ & 27,304 & 26,005 & 95.2 & 0.15 & 1,287 & 4.8 & 0.15 \\
\hline Male & $3,725,120$ & 5,375 & 5,155 & 95.9 & 0.32 & 217 & 4.1 & 0.32 \\
\hline $\begin{array}{l}\text { Female } \\
\text { Race }\end{array}$ & $12,823,107$ & 21,929 & 20,850 & 95.0 & 0.17 & 1,070 & 5.0 & 0.17 \\
\hline White & $12,980,558$ & 20,119 & 18,989 & 94.5 & 0.19 & 1,123 & 5.5 & 0.19 \\
\hline Black & $2,608,720$ & 5,554 & 5,425 & 97.9 & 0.22 & 126 & 2.1 & 0.22 \\
\hline $\begin{array}{c}\text { Other } \\
\text { Ethnicity }\end{array}$ & 958,949 & 1,631 & 1,591 & 97.4 & 0.48 & 38 & 2.6 & 0.48 \\
\hline Non-Hispanic & $15,172,660$ & 23,735 & 22,527 & 95.0 & 0.16 & 1,197 & 5.0 & 0.16 \\
\hline $\begin{array}{l}\text { Hispanic } \\
\text { Age group }\end{array}$ & $1,375,568$ & 3,569 & 3,478 & 97.5 & 0.31 & 90 & 2.5 & 0.31 \\
\hline $18-24$ & $1,725,603$ & 2,299 & 2,272 & 98.9 & 0.27 & 27 & 1.1 & 0.27 \\
\hline $25-64$ & $14,247,961$ & 23,836 & 22,735 & 95.2 & 0.17 & 1,089 & 4.8 & 0.17 \\
\hline $\begin{array}{l}\quad 65 \text { and older } \\
\text { Education }^{3}\end{array}$ & 574,664 & 1,169 & 998 & 84.2 & 1.37 & 171 & 15.8 & 1.37 \\
\hline Less than HS & $1,141,190$ & 2,376 & 2,278 & 95.9 & 0.44 & 97 & 4.1 & 0.44 \\
\hline High school & $3,582,213$ & 6,011 & 5,748 & 95.5 & 0.31 & 259 & 4.5 & 0.31 \\
\hline $\begin{array}{l}\text { More than HS } \\
\text { Insurance }\end{array}$ & $11,751,646$ & 18,800 & 17,868 & 95.1 & 0.18 & 926 & 4.9 & 0.18 \\
\hline Insured & $14,662,946$ & 23,754 & 22,586 & 95.1 & 0.17 & 1,158 & 4.9 & 0.17 \\
\hline Uninsured & $1,839,325$ & 3,495 & 3,367 & 96.3 & 0.38 & 126 & 3.7 & 0.38 \\
\hline
\end{tabular}

Source: Contract Report (March 2010). NORA Morbidity and Disability: The National Health Interview Survey (NHIS) $1997-2007$. Department of Epidemiology and Public Health, University of Miami School of Medicine

The estimates from this table are based on a question from the National Health Interview Survey that asked respondents "Have you EVER been told by a doctor or other health professional that you had cancer or a malignancy of any kind? "

1 Sample size from the National Health Interview Survey for the years 1997-2007

2 Percent (prevalence) estimated from the National Health Interview Survey for the years 1997-2007

${ }^{3}$ Response categories include (1) less than High School graduate, (2) High School graduate or GED, and (3) Some college or higher education. 
Table 25. Prevalence of hypertension estimated for workers 18 years and older, All NORA sectors, National Health Interview Survey, 1997-2007

\begin{tabular}{|c|c|c|c|c|c|c|c|c|}
\hline \multirow[b]{2}{*}{ Subgroup } & \multirow{2}{*}{$\begin{array}{c}\text { US } \\
\text { Estimated } \\
\text { Worker } \\
\text { Population }\end{array}$} & \multirow{2}{*}{$\begin{array}{c}\text { NHIS } \\
\text { sample } \\
\text { size }^{1}\end{array}$} & \multicolumn{3}{|c|}{ No } & \multicolumn{3}{|c|}{ Yes } \\
\hline & & & Number & Percent $^{2}$ & $\begin{array}{c}\text { Standard } \\
\text { error }\end{array}$ & Number & Percent $^{2}$ & $\begin{array}{c}\text { Standaro } \\
\text { error }\end{array}$ \\
\hline $\begin{array}{l}\text { All subgroups } \\
\text { Gender }\end{array}$ & $126,898,030$ & 196,924 & 161,325 & 82.3 & 0.13 & 35,522 & 17.7 & 0.13 \\
\hline Male & $68,530,792$ & 97,768 & 79,864 & 81.7 & 0.17 & 17,859 & 18.3 & 0.17 \\
\hline $\begin{array}{l}\text { Female } \\
\text { Race }\end{array}$ & $58,367,238$ & 99,156 & 81,461 & 83.0 & 0.16 & 17,663 & 17.0 & 0.16 \\
\hline White & $105,313,053$ & 157,040 & 130,025 & 82.8 & 0.14 & 26,956 & 17.2 & 0.14 \\
\hline Black & $14,056,560$ & 27,262 & 20,423 & 76.5 & 0.33 & 6,828 & 23.5 & 0.33 \\
\hline $\begin{array}{c}\text { Other } \\
\text { Ethnicity }\end{array}$ & $7,528,417$ & 12,622 & 10,877 & 86.1 & 0.41 & 1,738 & 13.9 & 0.41 \\
\hline Non-Hispanic & $111,862,532$ & 163,004 & 131,564 & 81.6 & 0.14 & 31,374 & 18.4 & 0.14 \\
\hline $\begin{array}{l}\text { Hispanic } \\
\text { Age group }\end{array}$ & $15,035,498$ & 33,920 & 29,761 & 88.0 & 0.25 & 4,148 & 12.0 & 0.25 \\
\hline $18-24$ & $16,959,193$ & 21,858 & 20,803 & 95.4 & 0.18 & 1,046 & 4.6 & 0.18 \\
\hline $25-64$ & $105,946,456$ & 167,739 & 136,687 & 81.4 & 0.14 & 30,987 & 18.6 & 0.14 \\
\hline $\begin{array}{l}\quad 65 \text { and older } \\
\text { Education }^{3}\end{array}$ & $3,992,381$ & 7,327 & 3,835 & 52.5 & 0.71 & 3,489 & 47.5 & 0.71 \\
\hline Less than HS & $14,798,890$ & 26,367 & 21,495 & 81.7 & 0.32 & 4,859 & 18.3 & 0.32 \\
\hline High school & $36,048,733$ & 54,264 & 43,489 & 80.7 & 0.22 & 10,752 & 19.3 & 0.22 \\
\hline $\begin{array}{l}\text { More than HS } \\
\text { Insurance }\end{array}$ & $75,434,176$ & 115,325 & 95,554 & 83.2 & 0.15 & 19,733 & 16.8 & 0.15 \\
\hline Insured & $106,279,655$ & 161,665 & 130,659 & 81.3 & 0.14 & 30,947 & 18.7 & 0.14 \\
\hline Uninsured & $20,282,002$ & 34,830 & 30,291 & 87.5 & 0.25 & 4,522 & 12.5 & 0.25 \\
\hline
\end{tabular}

Source: Contract Report (March 2010). NORA Morbidity and Disability: The National Health Interview Survey (NHIS) $1997-2007$. Department of Epidemiology and Public Health, University of Miami School of Medicine

The estimates from this table are based on a question from the National Health Interview Survey that asked respondents "Have you EVER been told by a doctor or other health professional that you had hypertension, also called high blood pressure?"

1 Sample size from the National Health Interview Survey for the years 1997-2007

2 Percent (prevalence) estimated from the National Health Interview Survey for the years 1997-2007

${ }_{3}$ Response categories include (1) less than High School graduate, (2) High School graduate or GED, and (3) Some college or higher education. 
Table 26. Prevalence of hypertension estimated for workers 18 years and older, Healthcare and Social Assistance sector, National Health Interview Survey, 1997-2007

\begin{tabular}{|c|c|c|c|c|c|c|c|c|}
\hline \multirow[b]{2}{*}{ Subgroup } & \multirow{2}{*}{$\begin{array}{c}\text { US } \\
\text { Estimated } \\
\text { Worker } \\
\text { Population }\end{array}$} & \multirow{2}{*}{$\begin{array}{c}\text { NHIS } \\
\text { sample } \\
\text { size }^{1}\end{array}$} & \multicolumn{3}{|c|}{ No } & \multicolumn{3}{|c|}{ Yes } \\
\hline & & & Number & Percent $^{2}$ & $\begin{array}{l}\text { Standard } \\
\text { error }\end{array}$ & Number & Percent ${ }^{2}$ & $\begin{array}{c}\text { Standard } \\
\text { error }\end{array}$ \\
\hline $\begin{array}{l}\text { All subgroups } \\
\text { Gender }\end{array}$ & $16,548,227$ & 27,304 & 21,644 & 80.3 & 0.30 & 5,656 & 19.7 & 0.30 \\
\hline Male & $3,725,120$ & 5,375 & 4,201 & 79.3 & 0.64 & 1,174 & 20.7 & 0.64 \\
\hline $\begin{array}{l}\text { Female } \\
\text { Race }\end{array}$ & $12,823,107$ & 21,929 & 17,443 & 80.6 & 0.33 & 4,482 & 19.4 & 0.33 \\
\hline White & $12,980,558$ & 20,119 & 16,354 & 81.8 & 0.33 & 3,762 & 18.2 & 0.33 \\
\hline Black & $2,608,720$ & 5,554 & 3,938 & 71.9 & 0.74 & 1,615 & 28.1 & 0.74 \\
\hline $\begin{array}{c}\text { Other } \\
\text { Ethnicity }\end{array}$ & 958,949 & 1,631 & 1,352 & 83.8 & 1.14 & 279 & 16.2 & 1.14 \\
\hline Non-Hispanic & $15,172,660$ & 23,735 & 18,671 & 80.0 & 0.32 & 5,060 & 20.0 & 0.32 \\
\hline $\begin{array}{l}\text { Hispanic } \\
\text { Age group }\end{array}$ & $1,375,568$ & 3,569 & 2,973 & 83.7 & 0.76 & 596 & 16.3 & 0.76 \\
\hline $18-24$ & $1,725,603$ & 2,299 & 2,173 & 94.7 & 0.58 & 126 & 5.3 & 0.58 \\
\hline $25-64$ & $14,247,961$ & 23,836 & 18,883 & 79.8 & 0.32 & 4,949 & 20.2 & 0.32 \\
\hline $\begin{array}{l}\quad 65 \text { and older } \\
\text { Education }^{3}\end{array}$ & 574,664 & 1,169 & 588 & 51.2 & 1.65 & 581 & 48.8 & 1.65 \\
\hline Less than HS & $1,141,190$ & 2,376 & 1,712 & 72.7 & 1.13 & 664 & 27.3 & 1.13 \\
\hline High school & $3,582,213$ & 6,011 & 4,540 & 76.7 & 0.64 & 1,470 & 23.3 & 0.64 \\
\hline $\begin{array}{l}\text { More than HS } \\
\text { Insurance }\end{array}$ & $11,751,646$ & 18,800 & 15,314 & 82.3 & 0.32 & 3,484 & 17.7 & 0.32 \\
\hline Insured & $14,662,946$ & 23,754 & 18,786 & 80.2 & 0.31 & 4,964 & 19.8 & 0.31 \\
\hline Uninsured & $1,839,325$ & 3,495 & 2,809 & 81.4 & 0.80 & 686 & 18.6 & 0.80 \\
\hline
\end{tabular}

Source: Contract Report (March 2010). NORA Morbidity and Disability: The National Health Interview Survey (NHIS) $1997-2007$. Department of Epidemiology and Public Health, University of Miami School of Medicine

The estimates from this table are based on a question from the National Health Interview Survey that asked respondents "Have you EVER been told by a doctor or other health professional that you had hypertension, also called high blood pressure?"

1 Sample size from the National Health Interview Survey for the years 1997-2007

2 Percent (prevalence) estimated from the National Health Interview Survey for the years 1997-2007

${ }^{3}$ Response categories include (1) less than High School graduate, (2) High School graduate or GED, and (3) Some college or higher education. 
Table 27. Prevalence of heart disease estimated for workers 18 years and older, All NORA sectors, National Health Interview Survey, 1997-2007

\begin{tabular}{|c|c|c|c|c|c|c|c|c|}
\hline \multirow[b]{2}{*}{ Subgroup } & \multirow{2}{*}{$\begin{array}{c}\text { US } \\
\text { Estimated } \\
\text { Worker } \\
\text { Population }\end{array}$} & \multirow{2}{*}{$\begin{array}{c}\text { NHIS } \\
\text { sample } \\
\text { size }^{1}\end{array}$} & \multicolumn{3}{|c|}{ No } & \multicolumn{3}{|c|}{ Yes } \\
\hline & & & Number & Percent $^{2}$ & $\begin{array}{l}\text { Standard } \\
\text { error }\end{array}$ & Number & Percent $^{2}$ & $\begin{array}{l}\text { Standard } \\
\text { error }\end{array}$ \\
\hline $\begin{array}{l}\text { All subgroups } \\
\text { Gender }\end{array}$ & $126,898,030$ & 196,924 & 184,045 & 93.5 & 0.07 & 12,815 & 6.5 & 0.07 \\
\hline Male & $68,530,792$ & 97,768 & 91,420 & 93.5 & 0.10 & 6,314 & 6.5 & 0.10 \\
\hline $\begin{array}{l}\text { Female } \\
\text { Race }\end{array}$ & $58,367,238$ & 99,156 & 92,625 & 93.5 & 0.10 & 6,501 & 6.5 & 0.10 \\
\hline White & $105,313,053$ & 157,040 & 146,143 & 93.1 & 0.08 & 10,848 & 6.9 & 0.08 \\
\hline Black & $14,056,560$ & 27,262 & 25,774 & 95.0 & 0.17 & 1,477 & 5.0 & 0.17 \\
\hline $\begin{array}{l}\text { Other } \\
\text { Ethnicity }\end{array}$ & $7,528,417$ & 12,622 & 12,128 & 96.1 & 0.23 & 490 & 3.9 & 0.23 \\
\hline Non-Hispanic & $111,862,532$ & 163,004 & 151,396 & 93.1 & 0.08 & 11,554 & 6.9 & 0.08 \\
\hline $\begin{array}{l}\text { Hispanic } \\
\text { Age group }\end{array}$ & $15,035,498$ & 33,920 & 32,649 & 96.4 & 0.13 & 1,261 & 3.6 & 0.13 \\
\hline $18-24$ & $16,959,193$ & 21,858 & 21,157 & 96.9 & 0.15 & 698 & 3.1 & 0.15 \\
\hline $25-64$ & $105,946,456$ & 167,739 & 157,135 & 93.6 & 0.08 & 10,549 & 6.4 & 0.08 \\
\hline $\begin{array}{l}\quad 65 \text { and older } \\
\text { Education }^{3}\end{array}$ & $3,992,381$ & 7,327 & 5,753 & 77.3 & 0.57 & 1,568 & 22.7 & 0.57 \\
\hline Less than HS & $14,798,890$ & 26,367 & 24,798 & 94.0 & 0.20 & 1,558 & 6.0 & 0.20 \\
\hline High school & $36,048,733$ & 54,264 & 50,797 & 93.6 & 0.13 & 3,450 & 6.4 & 0.13 \\
\hline $\begin{array}{l}\text { More than HS } \\
\text { Insurance }\end{array}$ & $75,434,176$ & 115,325 & 107,535 & 93.3 & 0.09 & 7,758 & 6.7 & 0.09 \\
\hline Insured & $106,279,655$ & 161,665 & 150,477 & 93.2 & 0.08 & 11,137 & 6.8 & 0.08 \\
\hline Uninsured & $20,282,002$ & 34,830 & 33,153 & 95.3 & 0.14 & 1,664 & 4.7 & 0.14 \\
\hline
\end{tabular}

Source: Contract Report (March 2010). NORA Morbidity and Disability: The National Health Interview Survey (NHIS) $1997-2007$. Department of Epidemiology and Public Health, University of Miami School of Medicine

The estimates from this table are based on a question from the National Health Interview Survey that asked respondents "Have you EVER been told by a doctor or other health professional that you had heart disease?. Based on NHIS questions of specific diseases: Coronary heart disease, Angina, Heart attack, or Any kind of heart condition or heart disease?

1 Sample size from the National Health Interview Survey for the years 1997-2007

2 Percent (prevalence) estimated from the National Health Interview Survey for the years 1997-2007

${ }^{3}$ Response categories include (1) less than High School graduate, (2) High School graduate or GED, and (3) Some college or higher education. 
Table 28. Prevalence of heart disease estimated for workers 18 years and older, Healthcare and Social Assistance sector, National Health Interview Survey, 1997-2007

\begin{tabular}{|c|c|c|c|c|c|c|c|c|}
\hline \multirow[b]{2}{*}{ Subgroup } & \multirow{2}{*}{$\begin{array}{c}\text { US } \\
\text { Estimated } \\
\text { Worker } \\
\text { Population }\end{array}$} & \multirow{2}{*}{$\begin{array}{c}\text { NHIS } \\
\text { sample } \\
\text { size }^{1}\end{array}$} & \multicolumn{3}{|c|}{ No } & \multicolumn{3}{|c|}{ Yes } \\
\hline & & & Number & Percent $^{2}$ & $\begin{array}{l}\text { Standard } \\
\text { error }\end{array}$ & Number & Percent ${ }^{2}$ & $\begin{array}{c}\text { Standard } \\
\text { error }\end{array}$ \\
\hline $\begin{array}{l}\text { All subgroups } \\
\text { Gender }\end{array}$ & $16,548,227$ & 27,304 & 25,177 & 92.4 & 0.19 & 2,120 & 7.6 & 0.19 \\
\hline Male & $3,725,120$ & 5,375 & 4,950 & 92.5 & 0.42 & 424 & 7.5 & 0.42 \\
\hline $\begin{array}{l}\text { Female } \\
\text { Race }\end{array}$ & $12,823,107$ & 21,929 & 20,227 & 92.4 & 0.21 & 1,696 & 7.6 & 0.21 \\
\hline White & $12,980,558$ & 20,119 & 18,432 & 91.9 & 0.22 & 1,683 & 8.1 & 0.22 \\
\hline Black & $2,608,720$ & 5,554 & 5,194 & 94.0 & 0.39 & 358 & 6.0 & 0.39 \\
\hline $\begin{array}{c}\text { Other } \\
\text { Ethnicity }\end{array}$ & 958,949 & 1,631 & 1,551 & 95.5 & 0.59 & 79 & 4.5 & 0.59 \\
\hline Non-Hispanic & $15,172,660$ & 23,735 & 21,807 & 92.2 & 0.20 & 1,921 & 7.8 & 0.20 \\
\hline $\begin{array}{l}\text { Hispanic } \\
\text { Age group }\end{array}$ & $1,375,568$ & 3,569 & 3,370 & 94.3 & 0.50 & 199 & 5.7 & 0.50 \\
\hline $18-24$ & $1,725,603$ & 2,299 & 2,219 & 96.8 & 0.43 & 80 & 3.2 & 0.43 \\
\hline $25-64$ & $14,247,961$ & 23,836 & 22,038 & 92.4 & 0.20 & 1,792 & 7.6 & 0.20 \\
\hline $\begin{array}{l}\quad 65 \text { and older } \\
\text { Education }^{3}\end{array}$ & 574,664 & 1,169 & 920 & 78.9 & 1.37 & 248 & 21.1 & 1.37 \\
\hline Less than HS & $1,141,190$ & 2,376 & 2,162 & 91.7 & 0.71 & 214 & 8.3 & 0.71 \\
\hline High school & $3,582,213$ & 6,011 & 5,546 & 92.3 & 0.39 & 463 & 7.7 & 0.39 \\
\hline $\begin{array}{l}\text { More than HS } \\
\text { Insurance }\end{array}$ & $11,751,646$ & 18,800 & 17,360 & 92.5 & 0.22 & 1,437 & 7.5 & 0.22 \\
\hline Insured & $14,662,946$ & 23,754 & 21,850 & 92.2 & 0.20 & 1,897 & 7.8 & 0.20 \\
\hline Uninsured & $1,839,325$ & 3,495 & 3,274 & 93.7 & 0.53 & 221 & 6.3 & 0.53 \\
\hline
\end{tabular}

Source: Contract Report (March 2010). NORA Morbidity and Disability: The National Health Interview Survey (NHIS) $1997-2007$. Department of Epidemiology and Public Health, University of Miami School of Medicine

The estimates from this table are based on a question from the National Health Interview Survey that asked respondents "Have you EVER been told by a doctor or other health professional that you had heart disease?. Based on NHIS questions of specific diseases: Coronary heart disease, Angina, Heart attack, or Any kind of heart condition or heart disease?

1 Sample size from the National Health Interview Survey for the years 1997-2007

2 Percent (prevalence) estimated from the National Health Interview Survey for the years 1997-2007

${ }_{3}$ Response categories include (1) less than High School graduate, (2) High School graduate or GED, and (3) Some college or higher education. 
Table 29. Prevalence of asthma estimated for workers 18 years and older, All NORA sectors, National Health Interview Survey, 1997-2007

\begin{tabular}{|c|c|c|c|c|c|c|c|c|}
\hline \multirow[b]{2}{*}{ Subgroup } & \multirow{2}{*}{$\begin{array}{c}\text { US } \\
\text { Estimated } \\
\text { Worker } \\
\text { Population }\end{array}$} & \multirow{2}{*}{$\begin{array}{c}\text { NHIS } \\
\text { sample } \\
\text { size }^{1}\end{array}$} & \multicolumn{3}{|c|}{ No } & \multicolumn{3}{|c|}{ Yes } \\
\hline & & & Number & Percent $^{2}$ & $\begin{array}{l}\text { Standard } \\
\text { error }\end{array}$ & Number & Percent $^{2}$ & $\begin{array}{l}\text { Standard } \\
\text { error }\end{array}$ \\
\hline $\begin{array}{l}\text { All subgroups } \\
\text { Gender }\end{array}$ & $126,898,030$ & 196,924 & 178,336 & 90.6 & 0.09 & 18,462 & 9.4 & 0.09 \\
\hline Male & $68,530,792$ & 97,768 & 90,054 & 91.9 & 0.11 & 7,653 & 8.1 & 0.11 \\
\hline $\begin{array}{l}\text { Female } \\
\text { Race }\end{array}$ & $58,367,238$ & 99,156 & 88,282 & 89.0 & 0.13 & 10,809 & 11.0 & 0.13 \\
\hline White & $105,313,053$ & 157,040 & 142,231 & 90.5 & 0.10 & 14,708 & 9.5 & 0.10 \\
\hline Black & $14,056,560$ & 27,262 & 24,540 & 90.4 & 0.24 & 2,705 & 9.6 & 0.24 \\
\hline $\begin{array}{l}\text { Other } \\
\text { Ethnicity }\end{array}$ & $7,528,417$ & 12,622 & 11,565 & 92.1 & 0.32 & 1,049 & 7.9 & 0.32 \\
\hline Non-Hispanic & $111,862,532$ & 163,004 & 146,836 & 90.2 & 0.10 & 16,056 & 9.8 & 0.10 \\
\hline $\begin{array}{l}\text { Hispanic } \\
\text { Age group }\end{array}$ & $15,035,498$ & 33,920 & 31,500 & 93.1 & 0.21 & 2,406 & 6.9 & 0.21 \\
\hline $18-24$ & $16,959,193$ & 21,858 & 19,070 & 86.9 & 0.28 & 2,776 & 13.1 & 0.28 \\
\hline $25-64$ & $105,946,456$ & 167,739 & 152,519 & 91.1 & 0.10 & 15,119 & 8.9 & 0.10 \\
\hline $\begin{array}{l}\quad 65 \text { and older } \\
\text { Education }^{3}\end{array}$ & $3,992,381$ & 7,327 & 6,747 & 92.1 & 0.37 & 567 & 7.9 & 0.37 \\
\hline Less than HS & $14,798,890$ & 26,367 & 24,435 & 92.3 & 0.22 & 1,912 & 7.7 & 0.22 \\
\hline High school & $36,048,733$ & 54,264 & 49,653 & 91.4 & 0.15 & 4,581 & 8.6 & 0.15 \\
\hline $\begin{array}{l}\text { More than HS } \\
\text { Insurance }\end{array}$ & $75,434,176$ & 115,325 & 103,344 & 89.8 & 0.12 & 11,913 & 10.2 & 0.12 \\
\hline Insured & $106,279,655$ & 161,665 & 145,999 & 90.4 & 0.10 & 15,562 & 9.6 & 0.10 \\
\hline Uninsured & $20,282,002$ & 34,830 & 31,949 & 91.2 & 0.21 & 2,860 & 8.8 & 0.21 \\
\hline
\end{tabular}

Source: Contract Report (March 2010). NORA Morbidity and Disability: The National Health Interview Survey (NHIS) $1997-2007$. Department of Epidemiology and Public Health, University of Miami School of Medicine

The estimates from this table are based on a question from the National Health Interview Survey that asked respondents "Have you EVER been told by a doctor or other health professional that you had asthma?

1 Sample size from the National Health Interview Survey for the years 1997-2007

${ }^{2}$ Percent (prevalence) estimated from the National Health Interview Survey for the years 1997-2007

3 Response categories include (1) less than High School graduate, (2) High School graduate or GED, and (3) Some college or higher education. 
Table 30. Prevalence of asthma estimated for workers 18 years and older, Healthcare and Social Assistance sector, National Health Interview Survey, 1997-2007

\begin{tabular}{|c|c|c|c|c|c|c|c|c|}
\hline \multirow[b]{2}{*}{ Subgroup } & \multirow{2}{*}{$\begin{array}{c}\text { US } \\
\text { Estimated } \\
\text { Worker } \\
\text { Population }\end{array}$} & \multirow{2}{*}{$\begin{array}{c}\text { NHIS } \\
\text { sample } \\
\text { size }^{1}\end{array}$} & \multicolumn{3}{|c|}{ No } & \multicolumn{3}{|c|}{ Yes } \\
\hline & & & Number & Percent $^{2}$ & $\begin{array}{l}\text { Standard } \\
\text { error }\end{array}$ & Number & Percent ${ }^{2}$ & $\begin{array}{c}\text { Standard } \\
\text { error }\end{array}$ \\
\hline $\begin{array}{l}\text { All subgroups } \\
\text { Gender }\end{array}$ & $16,548,227$ & 27,304 & 24,301 & 89.0 & 0.23 & 2,992 & 11.0 & 0.23 \\
\hline Male & $3,725,120$ & 5,375 & 4,906 & 90.9 & 0.49 & 468 & 9.1 & 0.49 \\
\hline $\begin{array}{l}\text { Female } \\
\text { Race }\end{array}$ & $12,823,107$ & 21,929 & 19,395 & 88.5 & 0.26 & 2,524 & 11.5 & 0.26 \\
\hline White & $12,980,558$ & 20,119 & 17,899 & 88.9 & 0.26 & 2,211 & 11.1 & 0.26 \\
\hline Black & $2,608,720$ & 5,554 & 4,945 & 89.3 & 0.51 & 607 & 10.7 & 0.51 \\
\hline $\begin{array}{c}\text { Other } \\
\text { Ethnicity }\end{array}$ & 958,949 & 1,631 & 1,457 & 90.4 & 0.90 & 174 & 9.6 & 0.90 \\
\hline Non-Hispanic & $15,172,660$ & 23,735 & 21,095 & 89.0 & 0.24 & 2,629 & 11.0 & 0.24 \\
\hline $\begin{array}{l}\text { Hispanic } \\
\text { Age group }\end{array}$ & $1,375,568$ & 3,569 & 3,206 & 89.6 & 0.68 & 363 & 10.4 & 0.68 \\
\hline $18-24$ & $1,725,603$ & 2,299 & 1,979 & 84.6 & 0.96 & 318 & 15.4 & 0.96 \\
\hline $25-64$ & $14,247,961$ & 23,836 & 21,245 & 89.4 & 0.23 & 2,584 & 10.6 & 0.23 \\
\hline $\begin{array}{l}\quad 65 \text { and older } \\
\text { Education }^{3}\end{array}$ & 574,664 & 1,169 & 1,077 & 92.4 & 0.84 & 90 & 7.6 & 0.84 \\
\hline Less than HS & $1,141,190$ & 2,376 & 2,124 & 89.7 & 0.74 & 252 & 10.3 & 0.74 \\
\hline High school & $3,582,213$ & 6,011 & 5,418 & 89.9 & 0.47 & 590 & 10.1 & 0.47 \\
\hline $\begin{array}{l}\text { More than HS } \\
\text { Insurance }\end{array}$ & $11,751,646$ & 18,800 & 16,654 & 88.7 & 0.28 & 2,139 & 11.3 & 0.28 \\
\hline Insured & $14,662,946$ & 23,754 & 21,152 & 89.2 & 0.23 & 2,592 & 10.8 & 0.23 \\
\hline Uninsured & $1,839,325$ & 3,495 & 3,100 & 87.7 & 0.75 & 394 & 12.3 & 0.75 \\
\hline
\end{tabular}

Source: Contract Report (March 2010). NORA Morbidity and Disability: The National Health Interview Survey (NHIS) $1997-2007$. Department of Epidemiology and Public Health, University of Miami School of Medicine

The estimates from this table are based on a question from the National Health Interview Survey that asked respondents "Have you EVER been told by a doctor or other health professional that you had asthma?

1 Sample size from the National Health Interview Survey for the years 1997-2007

2 Percent (prevalence) estimated from the National Health Interview Survey for the years 1997-2007

${ }^{3}$ Response categories include (1) less than High School graduate, (2) High School graduate or GED, and (3) Some college or higher education. 
Table 31. Prevalence of diabetes estimated for workers 18 years and older, All NORA sectors, National Health Interview Survey, 1997-2007

\begin{tabular}{|c|c|c|c|c|c|c|c|c|}
\hline \multirow[b]{2}{*}{ Subgroup } & \multirow{2}{*}{$\begin{array}{c}\text { US } \\
\text { Estimated } \\
\text { Worker } \\
\text { Population }\end{array}$} & \multirow{2}{*}{$\begin{array}{l}\text { NHIS } \\
\text { sample } \\
\text { size }^{1}\end{array}$} & \multicolumn{3}{|c|}{ No } & \multicolumn{3}{|c|}{ Yes } \\
\hline & & & Number & Percent $^{2}$ & $\begin{array}{l}\text { Standard } \\
\text { error }\end{array}$ & Number & Percent $^{2}$ & $\begin{array}{l}\text { Standard } \\
\text { error }\end{array}$ \\
\hline $\begin{array}{l}\text { All subgroups } \\
\text { Gender }\end{array}$ & $126,898,030$ & 196,924 & 187,575 & 96.1 & 0.05 & 7,783 & 3.9 & 0.05 \\
\hline Male & $68,530,792$ & 97,768 & 92,999 & 95.9 & 0.08 & 4,032 & 4.1 & 0.08 \\
\hline $\begin{array}{l}\text { Female } \\
\text { Race }\end{array}$ & $58,367,238$ & 99,156 & 94,576 & 96.4 & 0.07 & 3,751 & 3.6 & 0.07 \\
\hline White & $105,313,053$ & 157,040 & 150,173 & 96.4 & 0.06 & 5,676 & 3.6 & 0.06 \\
\hline Black & $14,056,560$ & 27,262 & 25,401 & 94.4 & 0.17 & 1,591 & 5.6 & 0.17 \\
\hline $\begin{array}{l}\text { Other } \\
\text { Ethnicity }\end{array}$ & $7,528,417$ & 12,622 & 12,001 & 95.8 & 0.24 & 516 & 4.2 & 0.24 \\
\hline Non-Hispanic & $111,862,532$ & 163,004 & 155,300 & 96.2 & 0.06 & 6,384 & 3.8 & 0.06 \\
\hline $\begin{array}{l}\text { Hispanic } \\
\text { Age group }\end{array}$ & $15,035,498$ & 33,920 & 32,275 & 95.9 & 0.13 & 1,399 & 4.1 & 0.13 \\
\hline $18-24$ & $16,959,193$ & 21,858 & 21,637 & 99.3 & 0.07 & 163 & 0.7 & 0.07 \\
\hline $25-64$ & $105,946,456$ & 167,739 & 159,636 & 96.0 & 0.06 & 6,743 & 4.0 & 0.06 \\
\hline $\begin{array}{l}\quad 65 \text { and older } \\
\text { Education }^{3}\end{array}$ & $3,992,381$ & 7,327 & 6,302 & 87.8 & 0.46 & 877 & 12.2 & 0.46 \\
\hline Less than HS & $14,798,890$ & 26,367 & 24,742 & 95.0 & 0.16 & 1,367 & 5.0 & 0.16 \\
\hline High school & $36,048,733$ & 54,264 & 51,490 & 95.9 & 0.10 & 2,297 & 4.1 & 0.10 \\
\hline $\begin{array}{l}\text { More than HS } \\
\text { Insurance }\end{array}$ & $75,434,176$ & 115,325 & 110,431 & 96.5 & 0.07 & 4,076 & 3.5 & 0.07 \\
\hline Insured & $106,279,655$ & 161,665 & 153,649 & 96.0 & 0.06 & 6,701 & 4.0 & 0.06 \\
\hline Uninsured & $20,282,002$ & 34,830 & 33,513 & 97.1 & 0.11 & 1,070 & 2.9 & 0.11 \\
\hline
\end{tabular}

Source: Contract Report (March 2010). NORA Morbidity and Disability: The National Health Interview Survey (NHIS) $1997-2007$. Department of Epidemiology and Public Health, University of Miami School of Medicine

The estimates from this table are based on a question from the National Health Interview Survey that asked respondents "Have you EVER been told by a doctor or other health professional that you have diabetes or sugar diabetes?

1 Sample size from the National Health Interview Survey for the years 1997-2007

${ }^{2}$ Percent (prevalence) estimated from the National Health Interview Survey for the years 1997-2007

${ }^{3}$ Response categories include (1) less than High School graduate, (2) High School graduate or GED, and (3) Some college or higher education. 
Table 32. Prevalence of diabetes estimated for workers 18 years and older, Healthcare and Social Assistance sector, National Health Interview Survey, 1997-2007

\begin{tabular}{|c|c|c|c|c|c|c|c|c|}
\hline \multirow[b]{2}{*}{ Subgroup } & \multirow{2}{*}{$\begin{array}{c}\text { US } \\
\text { Estimated } \\
\text { Worker } \\
\text { Population }\end{array}$} & \multirow{2}{*}{$\begin{array}{c}\text { NHIS } \\
\text { sample } \\
\text { size }^{1}\end{array}$} & \multicolumn{3}{|c|}{ No } & \multicolumn{3}{|c|}{ Yes } \\
\hline & & & Number & Percent $^{2}$ & $\begin{array}{l}\text { Standard } \\
\text { error }\end{array}$ & Number & Percent $^{2}$ & $\begin{array}{c}\text { Standard } \\
\text { error }\end{array}$ \\
\hline $\begin{array}{l}\text { All subgroups } \\
\text { Gender }\end{array}$ & $16,548,227$ & 27,304 & 25,713 & 95.4 & 0.15 & 1,335 & 4.6 & 0.15 \\
\hline Male & $3,725,120$ & 5,375 & 5,027 & 94.7 & 0.38 & 300 & 5.3 & 0.38 \\
\hline $\begin{array}{l}\text { Female } \\
\text { Race }\end{array}$ & $12,823,107$ & 21,929 & 20,686 & 95.7 & 0.16 & 1,035 & 4.3 & 0.16 \\
\hline White & $12,980,558$ & 20,119 & 19,098 & 95.9 & 0.17 & 864 & 4.1 & 0.17 \\
\hline Black & $2,608,720$ & 5,554 & 5,091 & 93.3 & 0.40 & 383 & 6.7 & 0.40 \\
\hline $\begin{array}{c}\text { Other } \\
\text { Ethnicity }\end{array}$ & 958,949 & 1,631 & 1,524 & 95.2 & 0.60 & 88 & 4.8 & 0.60 \\
\hline Non-Hispanic & $15,172,660$ & 23,735 & 22,385 & 95.6 & 0.16 & 1,125 & 4.4 & 0.16 \\
\hline $\begin{array}{l}\text { Hispanic } \\
\text { Age group }\end{array}$ & $1,375,568$ & 3,569 & 3,328 & 93.6 & 0.56 & 210 & 6.4 & 0.56 \\
\hline $18-24$ & $1,725,603$ & 2,299 & 2,266 & 99.0 & 0.22 & 25 & 1.0 & 0.22 \\
\hline $25-64$ & $14,247,961$ & 23,836 & 22,456 & 95.3 & 0.17 & 1,156 & 4.7 & 0.17 \\
\hline $\begin{array}{l}\quad 65 \text { and older } \\
\text { Education }^{3}\end{array}$ & 574,664 & 1,169 & 991 & 86.9 & 1.13 & 154 & 13.1 & 1.13 \\
\hline Less than HS & $1,141,190$ & 2,376 & 2,141 & 92.0 & 0.65 & 192 & 8.0 & 0.65 \\
\hline High school & $3,582,213$ & 6,011 & 5,576 & 94.0 & 0.37 & 363 & 6.0 & 0.37 \\
\hline $\begin{array}{l}\text { More than HS } \\
\text { Insurance }\end{array}$ & $11,751,646$ & 18,800 & 17,890 & 96.2 & 0.17 & 770 & 3.8 & 0.17 \\
\hline Insured & $14,662,946$ & 23,754 & 22,375 & 95.5 & 0.16 & 1,161 & 4.5 & 0.16 \\
\hline Uninsured & $1,839,325$ & 3,495 & 3,284 & 94.8 & 0.50 & 173 & 5.2 & 0.50 \\
\hline
\end{tabular}

Source: Contract Report (March 2010). NORA Morbidity and Disability: The National Health Interview Survey (NHIS) 1997-2007. Department of Epidemiology and Public Health, University of Miami School of Medicine

The estimates from this table are based on a question from the National Health Interview Survey that asked respondents "Have you EVER been told by a doctor or other health professional that you have diabetes or sugar diabetes?

1 Sample size from the National Health Interview Survey for the years 1997-2007

2 Percent (prevalence) estimated from the National Health Interview Survey for the years 1997-2007

${ }^{3}$ Response categories include (1) less than High School graduate, (2) High School graduate or GED, and (3) Some college or higher education. 
Table 33. Prevalence of severe psychological distress estimated for workers 18 years and older, All NORA sectors, National Health Interview Survey, 1997-2007

\begin{tabular}{|c|c|c|c|c|c|c|c|c|}
\hline \multirow[b]{2}{*}{ Subgroup } & \multirow{2}{*}{$\begin{array}{c}\text { US Estimated } \\
\text { Worker } \\
\text { Population }\end{array}$} & \multirow{2}{*}{$\begin{array}{l}\text { NHIS } \\
\text { sample } \\
\text { size }^{1}\end{array}$} & \multicolumn{3}{|c|}{ No } & \multicolumn{3}{|c|}{ Yes } \\
\hline & & & Number & Percent $^{2}$ & $\begin{array}{c}\text { Standard } \\
\text { error }\end{array}$ & Number & Percent ${ }^{2}$ & $\begin{array}{c}\text { Standarc } \\
\text { error }\end{array}$ \\
\hline $\begin{array}{l}\text { All subgroups } \\
\text { Gender }\end{array}$ & $126,898,030$ & 196,924 & 194,031 & 99.5 & 0.02 & 1,200 & 0.5 & 0.02 \\
\hline Male & $68,530,792$ & 97,768 & 96,329 & 99.6 & 0.02 & 449 & 0.4 & 0.02 \\
\hline $\begin{array}{l}\text { Female } \\
\text { Race }\end{array}$ & $58,367,238$ & 99,156 & 97,702 & 99.4 & 0.03 & 751 & 0.6 & 0.03 \\
\hline White & $105,313,053$ & 157,040 & 154,782 & 99.5 & 0.02 & 938 & 0.5 & 0.02 \\
\hline Black & $14,056,560$ & 27,262 & 26,877 & 99.5 & 0.05 & 173 & 0.5 & 0.05 \\
\hline $\begin{array}{c}\text { Other } \\
\text { Ethnicity }\end{array}$ & $7,528,417$ & 12,622 & 12,372 & 99.5 & 0.08 & 89 & 0.5 & 0.08 \\
\hline Non-Hispanic & $111,862,532$ & 163,004 & 160,715 & 99.5 & 0.02 & 875 & 0.5 & 0.02 \\
\hline $\begin{array}{l}\text { Hispanic } \\
\text { Age group }\end{array}$ & $15,035,498$ & 33,920 & 33,316 & 99.2 & 0.06 & 325 & 0.8 & 0.06 \\
\hline $18-24$ & $16,959,193$ & 21,858 & 21,568 & 99.5 & 0.06 & 130 & 0.5 & 0.06 \\
\hline $25-64$ & $105,946,456$ & 167,739 & 165,244 & 99.5 & 0.02 & 1,048 & 0.5 & 0.02 \\
\hline $\begin{array}{l}\quad 65 \text { and older } \\
\text { Education }^{3}\end{array}$ & $3,992,381$ & 7,327 & 7,219 & 99.7 & 0.08 & 22 & 0.3 & 0.08 \\
\hline Less than HS & $14,798,890$ & 26,367 & 25,731 & 98.8 & 0.08 & 359 & 1.2 & 0.08 \\
\hline High school & $36,048,733$ & 54,264 & 53,394 & 99.5 & 0.03 & 356 & 0.5 & 0.03 \\
\hline $\begin{array}{l}\text { More than HS } \\
\text { Insurance }\end{array}$ & $75,434,176$ & 115,325 & 114,089 & 99.6 & 0.02 & 472 & 0.4 & 0.02 \\
\hline Insured & $106,279,655$ & 161,665 & 159,562 & 99.6 & 0.02 & 790 & 0.4 & 0.02 \\
\hline Uninsured & $20,282,002$ & 34,830 & 34,055 & 99.0 & 0.06 & 409 & 1.0 & 0.06 \\
\hline
\end{tabular}

Source: Contract Report (March 2010). NORA Morbidity and Disability: The National Health Interview Survey (NHIS) $1997-2007$. Department of Epidemiology and Public Health, University of Miami School of Medicine

The estimates from this table are based on a question from the National Health Interview Survey that asked how often respondents experienced certain symptoms of psychological distress during the past 30 days: "How oftern did you feel (1) so sad that nothing could cheer you up?; (2) nervous?; (3) restless or fidgety?; (4) hopeless?; (5) that everything was an effort ?; and worthless?" See Pratt LA, Dey AN, Cohen AJ. Characteristics of adults with serious psychological distress as measured by the K6 scale. United States, 2001-04. Advance data from vital and health statistics; No. 382. Hyattsville, MD: National Center for Health Statistics, 2007. DHHS Publication No. (PHS) 2007-1250.

1 Sample size from the National Health Interview Survey for the years 1997-2007

2 Percent (prevalence) estimated from the National Health Interview Survey for the years 1997-2007

${ }_{3}$ Response categories include (1) less than High School graduate, (2) High School graduate or GED, and (3) Some college or higher education. 
Table 34. Prevalence of severe psychological distress estimated for workers 18 years and older, Healthcare and Social Assistance sector, National Health Interview Survey, 1997-2007

\begin{tabular}{|c|c|c|c|c|c|c|c|c|}
\hline \multirow[b]{2}{*}{ Subgroup } & \multirow{2}{*}{$\begin{array}{c}\text { US } \\
\text { Estimated } \\
\text { Worker } \\
\text { Population }\end{array}$} & \multirow{2}{*}{$\begin{array}{c}\text { NHIS } \\
\text { sample } \\
\text { size }^{1}\end{array}$} & \multicolumn{3}{|c|}{ No } & \multicolumn{3}{|c|}{ Yes } \\
\hline & & & Number & Percent $^{2}$ & $\begin{array}{l}\text { Standard } \\
\text { error }\end{array}$ & Number & Percent $^{2}$ & $\begin{array}{c}\text { Standard } \\
\text { error }\end{array}$ \\
\hline $\begin{array}{l}\text { All subgroups } \\
\text { Gender }\end{array}$ & $16,548,227$ & 27,304 & 26,916 & 99.4 & 0.05 & 181 & 0.6 & 0.05 \\
\hline Male & $3,725,120$ & 5,375 & 5,305 & 99.7 & 0.09 & 17 & 0.3 & 0.09 \\
\hline $\begin{array}{l}\text { Female } \\
\text { Race }\end{array}$ & $12,823,107$ & 21,929 & 21,611 & 99.4 & 0.06 & 164 & 0.6 & 0.06 \\
\hline White & $12,980,558$ & 20,119 & 19,837 & 99.4 & 0.06 & 133 & 0.6 & 0.06 \\
\hline Black & $2,608,720$ & 5,554 & 5,479 & 99.6 & 0.09 & 31 & 0.4 & 0.09 \\
\hline $\begin{array}{c}\text { Other } \\
\text { Ethnicity }\end{array}$ & 958,949 & 1,631 & 1,600 & 99.1 & 0.25 & 17 & 0.9 & 0.25 \\
\hline Non-Hispanic & $15,172,660$ & 23,735 & 23,408 & 99.5 & 0.05 & 140 & 0.5 & 0.05 \\
\hline $\begin{array}{l}\text { Hispanic } \\
\text { Age group }\end{array}$ & $1,375,568$ & 3,569 & 3,508 & 98.9 & 0.23 & 41 & 1.1 & 0.23 \\
\hline $18-24$ & $1,725,603$ & 2,299 & 2,268 & 99.4 & 0.16 & 18 & 0.6 & 0.16 \\
\hline $25-64$ & $14,247,961$ & 23,836 & 23,494 & 99.4 & 0.06 & 162 & 0.6 & 0.06 \\
\hline $\begin{array}{l}\quad 65 \text { and older } \\
\text { Education }^{3}\end{array}$ & 574,664 & 1,169 & 1,154 & 100.0 & 0.03 & 1 & 0.0 & 0.03 \\
\hline Less than HS & $1,141,190$ & 2,376 & 2,307 & 98.2 & 0.32 & 46 & 1.8 & 0.32 \\
\hline High school & $3,582,213$ & 6,011 & 5,907 & 99.4 & 0.10 & 51 & 0.6 & 0.10 \\
\hline $\begin{array}{l}\text { More than HS } \\
\text { Insurance }\end{array}$ & $11,751,646$ & 18,800 & 18,607 & 99.6 & 0.06 & 82 & 0.4 & 0.06 \\
\hline Insured & $14,662,946$ & 23,754 & 23,444 & 99.5 & 0.05 & 128 & 0.5 & 0.05 \\
\hline Uninsured & $1,839,325$ & 3,495 & 3,420 & 98.7 & 0.22 & 53 & 1.3 & 0.22 \\
\hline
\end{tabular}

Source: Contract Report (March 2010). NORA Morbidity and Disability: The National Health Interview Survey (NHIS) $1997-2007$. Department of Epidemiology and Public Health, University of Miami School of Medicine

The estimates from this table are based on a question from the National Health Interview Survey that asked how often respondents experienced certain symptoms of psychological distress during the past 30 days: "How oftern did you feel (1) so sad that nothing could cheer you up?; (2) nervous?; (3) restless or fidgety?; (4) hopeless?; (5) that everything was an effort ?; and worthless?" See Pratt LA, Dey AN, Cohen AJ. Characteristics of adults with serious psychological distress as measured by the K6 scale. United States, 2001-04. Advance data from vital and health statistics; No. 382. Hyattsville, MD: National Center for Health Statistics, 2007. DHHS Publication No. (PHS) 2007-1250.

1 Sample size from the National Health Interview Survey for the years 1997-2007

2 Percent (prevalence) estimated from the National Health Interview Survey for the years 1997-2007

${ }^{3}$ Response categories include (1) less than High School graduate, (2) High School graduate or GED, and (3) Some college or higher education. 
Table 35. Prevalence of not having seen a primary health care provider during the past 12 months estimated for workers 18 years and older, All NORA sectors, National Health Interview Survey, 1997-2007

\begin{tabular}{|c|c|c|c|c|c|c|c|c|}
\hline \multirow[b]{2}{*}{ Subgroup } & \multirow{2}{*}{$\begin{array}{c}\text { US } \\
\text { Estimated } \\
\text { Worker } \\
\text { Population }\end{array}$} & \multirow{2}{*}{$\begin{array}{c}\text { NHIS } \\
\text { sample } \\
\text { size }^{1}\end{array}$} & \multicolumn{3}{|c|}{ Past 12 months } & \multicolumn{3}{|c|}{1 year or greater } \\
\hline & & & Number & Percent $^{2}$ & $\begin{array}{c}\text { Standard } \\
\text { error }\end{array}$ & Number & Percent $^{2}$ & $\begin{array}{c}\text { Standard } \\
\text { error }\end{array}$ \\
\hline $\begin{array}{l}\text { All subgroups } \\
\text { Gender }\end{array}$ & $126,898,030$ & 196,924 & 136,250 & 69.8 & 0.18 & 59,536 & 30.2 & 0.18 \\
\hline Male & $68,530,792$ & 97,768 & 55,443 & 58.7 & 0.24 & 41,710 & 41.3 & 0.24 \\
\hline $\begin{array}{l}\text { Female } \\
\text { Race }\end{array}$ & $58,367,238$ & 99,156 & 80,807 & 82.8 & 0.18 & 17,826 & 17.2 & 0.18 \\
\hline White & $105,313,053$ & 157,040 & 108,698 & 70.1 & 0.19 & 47,471 & 29.9 & 0.19 \\
\hline Black & $14,056,560$ & 27,262 & 19,731 & 71.3 & 0.37 & 7,353 & 28.7 & 0.37 \\
\hline $\begin{array}{c}\text { Other } \\
\text { Ethnicity }\end{array}$ & $7,528,417$ & 12,622 & 7,821 & 62.7 & 0.61 & 4,712 & 37.3 & 0.61 \\
\hline Non-Hispanic & $111,862,532$ & 163,004 & 117,104 & 71.8 & 0.17 & 44,965 & 28.2 & 0.17 \\
\hline $\begin{array}{l}\text { Hispanic } \\
\text { Age group }\end{array}$ & $15,035,498$ & 33,920 & 19,146 & 55.2 & 0.45 & 14,571 & 44.8 & 0.45 \\
\hline $18-24$ & $16,959,193$ & 21,858 & 13,739 & 63.5 & 0.45 & 7,995 & 36.5 & 0.45 \\
\hline $25-64$ & $105,946,456$ & 167,739 & 116,570 & 70.3 & 0.18 & 50,204 & 29.7 & 0.18 \\
\hline $\begin{array}{l}\quad 65 \text { and older } \\
\text { Education }^{3}\end{array}$ & $3,992,381$ & 7,327 & 5,941 & 82.3 & 0.53 & 1,337 & 17.7 & 0.53 \\
\hline Less than HS & $14,798,890$ & 26,367 & 14,262 & 54.8 & 0.44 & 11,948 & 45.2 & 0.44 \\
\hline High school & $36,048,733$ & 54,264 & 36,098 & 66.8 & 0.29 & 17,854 & 33.2 & 0.29 \\
\hline $\begin{array}{l}\text { More than HS } \\
\text { Insurance }\end{array}$ & $75,434,176$ & 115,325 & 85,401 & 74.3 & 0.19 & 29,316 & 25.7 & 0.19 \\
\hline Insured & $106,279,655$ & 161,665 & 120,791 & 74.8 & 0.16 & 39,982 & 25.2 & 0.16 \\
\hline Uninsured & $20,282,002$ & 34,830 & 15,238 & 44.1 & 0.36 & 19,361 & 55.9 & 0.36 \\
\hline
\end{tabular}

Source: Contract Report (March 2010). NORA Morbidity and Disability: The National Health Interview Survey (NHIS) $1997-2007$. Department of Epidemiology and Public Health, University of Miami School of Medicine

The estimates from this table are based on a question from the National Health Interview Survey that asked respondents "During

the past 12 months, have you seen a primary health care provider (any of the following): Ob/GYN , general doctor?"

1 Sample size from the National Health Interview Survey for the years 1997-2007

${ }^{2}$ Percent (prevalence) estimated from the National Health Interview Survey for the years 1997-2007

${ }_{3}$ Response categories include (1) less than High School graduate, (2) High School graduate or GED, and (3) Some college or higher education. 
Table 36. Prevalence of not having seen a primary health care provider during the past 12 months estimated for workers 18 years and older, Healthcare and Social Assistance sector, National Health Interview Survey, 1997-2007

\begin{tabular}{|c|c|c|c|c|c|c|c|c|}
\hline \multirow[b]{2}{*}{ Subgroup } & \multirow{2}{*}{$\begin{array}{l}\text { US } \\
\text { Estimated } \\
\text { Worker } \\
\text { Population }\end{array}$} & \multirow{2}{*}{$\begin{array}{c}\text { NHIS } \\
\text { sample } \\
\text { size }^{1}\end{array}$} & \multicolumn{3}{|c|}{ Past 12 months } & \multicolumn{3}{|c|}{1 year or greater } \\
\hline & & & Number & Percent $^{2}$ & $\begin{array}{l}\text { Standard } \\
\text { error }\end{array}$ & Number & Percent $^{2}$ & $\begin{array}{c}\text { Standard } \\
\text { error }\end{array}$ \\
\hline $\begin{array}{l}\text { All subgroups } \\
\text { Gender }\end{array}$ & $16,548,227$ & 27,304 & 21,531 & 79.4 & 0.30 & 5,644 & 20.6 & 0.30 \\
\hline Male & $3,725,120$ & 5,375 & 3,308 & 62.4 & 0.78 & 2,030 & 37.6 & 0.78 \\
\hline $\begin{array}{l}\text { Female } \\
\text { Race }\end{array}$ & $12,823,107$ & 21,929 & 18,223 & 84.3 & 0.31 & 3,614 & 15.7 & 0.31 \\
\hline White & $12,980,558$ & 20,119 & 15,929 & 79.8 & 0.34 & 4,111 & 20.2 & 0.34 \\
\hline Black & $2,608,720$ & 5,554 & 4,430 & 80.0 & 0.68 & 1,090 & 20.0 & 0.68 \\
\hline $\begin{array}{c}\text { Other } \\
\text { Ethnicity }\end{array}$ & 958,949 & 1,631 & 1,172 & 71.2 & 1.47 & 443 & 28.8 & 1.47 \\
\hline Non-Hispanic & $15,172,660$ & 23,735 & 18,936 & 80.0 & 0.32 & 4,685 & 20.0 & 0.32 \\
\hline $\begin{array}{l}\text { Hispanic } \\
\text { Age group }\end{array}$ & $1,375,568$ & 3,569 & 2,595 & 72.1 & 1.01 & 959 & 27.9 & 1.01 \\
\hline $18-24$ & $1,725,603$ & 2,299 & 1,786 & 77.6 & 1.10 & 507 & 22.4 & 1.10 \\
\hline $25-64$ & $14,247,961$ & 23,836 & 18,787 & 79.5 & 0.32 & 4,931 & 20.5 & 0.32 \\
\hline $\begin{array}{l}\quad 65 \text { and older } \\
\text { Education }^{3}\end{array}$ & 574,664 & 1,169 & 958 & 82.3 & 1.18 & 206 & 17.7 & 1.18 \\
\hline Less than HS & $1,141,190$ & 2,376 & 1,731 & 72.8 & 1.20 & 633 & 27.2 & 1.20 \\
\hline High school & $3,582,213$ & 6,011 & 4,682 & 78.6 & 0.69 & 1,311 & 21.4 & 0.69 \\
\hline $\begin{array}{l}\text { More than HS } \\
\text { Insurance }\end{array}$ & $11,751,646$ & 18,800 & 15,040 & 80.3 & 0.35 & 3,669 & 19.7 & 0.35 \\
\hline Insured & $14,662,946$ & 23,754 & 19,383 & 81.7 & 0.31 & 4,259 & 18.3 & 0.31 \\
\hline Uninsured & $1,839,325$ & 3,495 & 2,108 & 60.6 & 1.03 & 1,371 & 39.4 & 1.03 \\
\hline
\end{tabular}

Source: Contract Report (March 2010). NORA Morbidity and Disability: The National Health Interview Survey (NHIS) 1997-2007. Department of Epidemiology and Public Health, University of Miami School of Medicine

The estimates from this table are based on a question from the National Health Interview Survey that asked respondents "During

the past 12 months, have you seen a primary health care provider (any of the following): Ob/GYN , general doctor?"

1 Sample size from the National Health Interview Survey for the years 1997-2007

2 Percent (prevalence) estimated from the National Health Interview Survey for the years 1997-2007

${ }^{3}$ Response categories include (1) less than High School graduate, (2) High School graduate or GED, and (3) Some college or higher education. 
Table 37. Prevalence of no dentist contact during the past year estimated for workers 18 years and older, All NORA sectors, National Health Interview Survey, 1997-2007

\begin{tabular}{|c|c|c|c|c|c|c|c|c|}
\hline \multirow[b]{2}{*}{ Subgroup } & \multirow{2}{*}{$\begin{array}{l}\text { US } \\
\text { Estimated } \\
\text { Worker } \\
\text { Population }\end{array}$} & \multirow{2}{*}{$\begin{array}{l}\text { NHIS } \\
\text { sample } \\
\text { size }^{1}\end{array}$} & \multicolumn{3}{|c|}{ Past year } & \multicolumn{3}{|c|}{1 year or greater } \\
\hline & & & Number & Percent $^{2}$ & $\begin{array}{l}\text { Standard } \\
\text { error }\end{array}$ & Number & Percent $^{2}$ & $\begin{array}{c}\text { Standard } \\
\text { error }\end{array}$ \\
\hline $\begin{array}{l}\text { All subgroups } \\
\text { Gender }\end{array}$ & $126,898,030$ & 196,924 & 125,540 & 65.8 & 0.20 & 69,530 & 34.2 & 0.20 \\
\hline Male & $68,530,792$ & 97,768 & 57,405 & 61.4 & 0.26 & 39,340 & 38.6 & 0.26 \\
\hline $\begin{array}{l}\text { Female } \\
\text { Race }\end{array}$ & $58,367,238$ & 99,156 & 68,135 & 71.0 & 0.22 & 30,190 & 29.0 & 0.22 \\
\hline White & $105,313,053$ & 157,040 & 102,144 & 67.0 & 0.22 & 53,528 & 33.0 & 0.22 \\
\hline Black & $14,056,560$ & 27,262 & 16,025 & 59.8 & 0.47 & 10,892 & 40.2 & 0.47 \\
\hline $\begin{array}{l}\text { Other } \\
\text { Ethnicity }\end{array}$ & $7,528,417$ & 12,622 & 7,371 & 60.7 & 0.62 & 5,110 & 39.3 & 0.62 \\
\hline Non-Hispanic & $111,862,532$ & 163,004 & 108,733 & 67.9 & 0.20 & 52,768 & 32.1 & 0.20 \\
\hline $\begin{array}{l}\text { Hispanic } \\
\text { Age group }\end{array}$ & $15,035,498$ & 33,920 & 16,807 & 50.2 & 0.49 & 16,762 & 49.8 & 0.49 \\
\hline $18-24$ & $16,959,193$ & 21,858 & 12,653 & 60.4 & 0.47 & 8,982 & 39.6 & 0.47 \\
\hline $25-64$ & $105,946,456$ & 167,739 & 108,270 & 66.7 & 0.20 & 57,933 & 33.3 & 0.20 \\
\hline $\begin{array}{l}\quad 65 \text { and older } \\
\text { Education }^{3}\end{array}$ & $3,992,381$ & 7,327 & 4,617 & 65.1 & 0.71 & 2,615 & 34.9 & 0.71 \\
\hline Less than HS & $14,798,890$ & 26,367 & 10,743 & 42.9 & 0.43 & 15,321 & 57.1 & 0.43 \\
\hline High school & $36,048,733$ & 54,264 & 31,151 & 58.9 & 0.30 & 22,524 & 41.1 & 0.30 \\
\hline $\begin{array}{l}\text { More than HS } \\
\text { Insurance }\end{array}$ & $75,434,176$ & 115,325 & 83,235 & 73.7 & 0.19 & 31,259 & 26.3 & 0.19 \\
\hline Insured & $106,279,655$ & 161,665 & 112,993 & 71.4 & 0.19 & 47,278 & 28.6 & 0.19 \\
\hline Uninsured & $20,282,002$ & 34,830 & 12,331 & 36.5 & 0.35 & 22,064 & 63.5 & 0.35 \\
\hline
\end{tabular}

Source: Contract Report (March 2010). NORA Morbidity and Disability: The National Health Interview Survey (NHIS) $1997-2007$. Department of Epidemiology and Public Health, University of Miami School of Medicine

The estimates from this table are based on a question from the National Health Interview Survey that asked respondents "About how long has it been since you last saw or talked to a dentist? Include all types of dentists, such as orthodontists, oral surgeons, and all other dental specialists, as well as dental hygienists."

1 Sample size from the National Health Interview Survey for the years 1997-2007

2 Percent (prevalence) estimated from the National Health Interview Survey for the years 1997-2007

${ }^{3}$ Response categories include (1) less than High School graduate, (2) High School graduate or GED, and (3) Some college or higher education. 
Table 38. Prevalence of no dentist contact during the past year estimated for workers 18 years and older, Healthcare and Social Assistance sector, National Health Interview Survey, 1997-2007

\begin{tabular}{|c|c|c|c|c|c|c|c|c|}
\hline \multirow[b]{2}{*}{ Subgroup } & \multirow{2}{*}{$\begin{array}{c}\text { US } \\
\text { Estimated } \\
\text { Worker } \\
\text { Population }\end{array}$} & \multirow{2}{*}{$\begin{array}{c}\text { NHIS } \\
\text { sample } \\
\text { size }^{1}\end{array}$} & \multicolumn{3}{|c|}{ Past year } & \multicolumn{3}{|c|}{1 year or greater } \\
\hline & & & Number & Percent $^{2}$ & $\begin{array}{l}\text { Standard } \\
\text { error }\end{array}$ & Number & Percent ${ }^{2}$ & $\begin{array}{c}\text { Standard } \\
\text { error }\end{array}$ \\
\hline $\begin{array}{l}\text { All subgroups } \\
\text { Gender }\end{array}$ & $16,548,227$ & 27,304 & 19,029 & 72.1 & 0.35 & 8,055 & 27.9 & 0.35 \\
\hline Male & $3,725,120$ & 5,375 & 3,691 & 71.0 & 0.73 & 1,634 & 29.0 & 0.73 \\
\hline $\begin{array}{l}\text { Female } \\
\text { Race }\end{array}$ & $12,823,107$ & 21,929 & 15,338 & 72.4 & 0.37 & 6,421 & 27.6 & 0.37 \\
\hline White & $12,980,558$ & 20,119 & 14,518 & 73.8 & 0.39 & 5,472 & 26.2 & 0.39 \\
\hline Black & $2,608,720$ & 5,554 & 3,415 & 64.2 & 0.82 & 2,070 & 35.8 & 0.82 \\
\hline $\begin{array}{c}\text { Other } \\
\text { Ethnicity }\end{array}$ & 958,949 & 1,631 & 1,096 & 69.6 & 1.39 & 513 & 30.4 & 1.39 \\
\hline Non-Hispanic & $15,172,660$ & 23,735 & 16,819 & 72.9 & 0.37 & 6,724 & 27.1 & 0.37 \\
\hline $\begin{array}{l}\text { Hispanic } \\
\text { Age group }\end{array}$ & $1,375,568$ & 3,569 & 2,210 & 63.4 & 1.04 & 1,331 & 36.6 & 1.04 \\
\hline $18-24$ & $1,725,603$ & 2,299 & 1,512 & 67.6 & 1.19 & 763 & 32.4 & 1.19 \\
\hline $25-64$ & $14,247,961$ & 23,836 & 16,755 & 72.8 & 0.36 & 6,901 & 27.2 & 0.36 \\
\hline $\begin{array}{l}\quad 65 \text { and older } \\
\text { Education }^{3}\end{array}$ & 574,664 & 1,169 & 762 & 68.6 & 1.56 & 391 & 31.4 & 1.56 \\
\hline Less than HS & $1,141,190$ & 2,376 & 1,152 & 50.9 & 1.35 & 1,190 & 49.1 & 1.35 \\
\hline High school & $3,582,213$ & 6,011 & 3,691 & 63.1 & 0.73 & 2,271 & 36.9 & 0.73 \\
\hline $\begin{array}{l}\text { More than HS } \\
\text { Insurance }\end{array}$ & $11,751,646$ & 18,800 & 14,125 & 77.0 & 0.38 & 4,554 & 23.0 & 0.38 \\
\hline Insured & $14,662,946$ & 23,754 & 17,529 & 75.7 & 0.35 & 6,040 & 24.3 & 0.35 \\
\hline Uninsured & $1,839,325$ & 3,495 & 1,462 & 42.8 & 1.04 & 2,001 & 57.2 & 1.04 \\
\hline
\end{tabular}

Source: Contract Report (March 2010). NORA Morbidity and Disability: The National Health Interview Survey (NHIS) $1997-2007$. Department of Epidemiology and Public Health, University of Miami School of Medicine

The estimates from this table are based on a question from the National Health Interview Survey that asked respondents "About how long has it been since you last saw or talked to a dentist? Include all types of dentists, such as orthodontists, oral surgeons, and all other dental specialists, as well as dental hygienists."

1 Sample size from the National Health Interview Survey for the years 1997-2007

2 Percent (prevalence) estimated from the National Health Interview Survey for the years 1997-2007

${ }_{3}^{3}$ Response categories include (1) less than High School graduate, (2) High School graduate or GED, and (3) Some college or higher education. 
Table 39. Prevalence of surgery during the past 12 months estimated for workers 18 years and older, All NORA sectors, National Health Interview Survey, 1997-2007

\begin{tabular}{|c|c|c|c|c|c|c|c|c|}
\hline \multirow[b]{2}{*}{ Subgroup } & \multirow{2}{*}{$\begin{array}{l}\text { US } \\
\text { Estimated } \\
\text { Worker } \\
\text { Population }\end{array}$} & \multirow{2}{*}{$\begin{array}{c}\text { NHIS } \\
\text { sample } \\
\text { size }^{1}\end{array}$} & \multicolumn{3}{|c|}{1 year or greater } & \multicolumn{3}{|c|}{ Past 12 months } \\
\hline & & & Number & Percent $^{2}$ & $\begin{array}{l}\text { Standard } \\
\text { error }\end{array}$ & Number & Percent $^{2}$ & $\begin{array}{c}\text { Standard } \\
\text { error }\end{array}$ \\
\hline $\begin{array}{l}\text { All subgroups } \\
\text { Gender }\end{array}$ & $126,898,030$ & 196,924 & 175,240 & 89.2 & 0.10 & 20,586 & 10.8 & 0.10 \\
\hline Male & $68,530,792$ & 97,768 & 88,896 & 91.0 & 0.12 & 8,305 & 9.0 & 0.12 \\
\hline $\begin{array}{l}\text { Female } \\
\text { Race }\end{array}$ & $58,367,238$ & 99,156 & 86,344 & 87.2 & 0.13 & 12,281 & 12.8 & 0.13 \\
\hline White & $105,313,053$ & 157,040 & 138,866 & 88.7 & 0.10 & 17,340 & 11.3 & 0.10 \\
\hline Black & $14,056,560$ & 27,262 & 24,718 & 91.5 & 0.22 & 2,360 & 8.5 & 0.22 \\
\hline $\begin{array}{c}\text { Other } \\
\text { Ethnicity }\end{array}$ & $7,528,417$ & 12,622 & 11,656 & 93.1 & 0.30 & 886 & 6.9 & 0.30 \\
\hline Non-Hispanic & $111,862,532$ & 163,004 & 143,682 & 88.6 & 0.10 & 18,419 & 11.4 & 0.10 \\
\hline $\begin{array}{l}\text { Hispanic } \\
\text { Age group }\end{array}$ & $15,035,498$ & 33,920 & 31,558 & 93.8 & 0.17 & 2,167 & 6.2 & 0.17 \\
\hline $18-24$ & $16,959,193$ & 21,858 & 19,811 & 91.0 & 0.24 & 1,931 & 9.0 & 0.24 \\
\hline $25-64$ & $105,946,456$ & 167,739 & 149,354 & 89.2 & 0.10 & 17,454 & 10.8 & 0.10 \\
\hline $\begin{array}{l}\quad 65 \text { and older } \\
\text { Education }^{3}\end{array}$ & $3,992,381$ & 7,327 & 6,075 & 82.4 & 0.53 & 1,201 & 17.6 & 0.53 \\
\hline Less than HS & $14,798,890$ & 26,367 & 24,349 & 92.5 & 0.22 & 1,869 & 7.5 & 0.22 \\
\hline High school & $36,048,733$ & 54,264 & 48,552 & 89.7 & 0.16 & 5,417 & 10.3 & 0.16 \\
\hline $\begin{array}{l}\text { More than HS } \\
\text { Insurance }\end{array}$ & $75,434,176$ & 115,325 & 101,471 & 88.4 & 0.12 & 13,244 & 11.6 & 0.12 \\
\hline Insured & $106,279,655$ & 161,665 & 141,965 & 88.2 & 0.11 & 18,824 & 11.8 & 0.11 \\
\hline Uninsured & $20,282,002$ & 34,830 & 32,893 & 94.8 & 0.15 & 1,728 & 5.2 & 0.15 \\
\hline
\end{tabular}

Source: Contract Report (March 2010). NORA Morbidity and Disability: The National Health Interview Survey (NHIS) $1997-2007$. Department of Epidemiology and Public Health, University of Miami School of Medicine

The estimates from this table are based on a question from the National Health Interview Survey that asked respondents "During the PAST 12 MONTHS have you had SURGERY or other surgical procedures either as an inpatient or an outpatient? This includes both major surgery and minor procedures such as setting bones or removing growths."

1 Sample size from the National Health Interview Survey for the years 1997-2007

2 Percent (prevalence) estimated from the National Health Interview Survey for the years 1997-2007

${ }^{3}$ Response categories include (1) less than High School graduate, (2) High School graduate or GED, and (3) Some college or higher education. 
Table 40. Prevalence of surgery during the past 12 months estimated for workers 18 years and older, Healthcare and Social Assistance sector, National Health Interview Survey, 1997-2007

\begin{tabular}{|c|c|c|c|c|c|c|c|c|}
\hline \multirow[b]{2}{*}{ Subgroup } & \multirow{2}{*}{$\begin{array}{c}\text { US } \\
\text { Estimated } \\
\text { Worker } \\
\text { Population }\end{array}$} & \multirow{2}{*}{$\begin{array}{c}\text { NHIS } \\
\text { sample } \\
\text { size }^{1}\end{array}$} & \multicolumn{3}{|c|}{1 year or greater } & \multicolumn{3}{|c|}{ Past 12 months } \\
\hline & & & Number & Percent $^{2}$ & $\begin{array}{l}\text { Standard } \\
\text { error }\end{array}$ & Number & Percent ${ }^{2}$ & $\begin{array}{c}\text { Standard } \\
\text { error }\end{array}$ \\
\hline $\begin{array}{c}\text { All subgroups } \\
\text { Gender }\end{array}$ & $16,548,227$ & 27,304 & 23,805 & 87.4 & 0.23 & 3,379 & 12.6 & 0.23 \\
\hline Male & $3,725,120$ & 5,375 & 4,853 & 90.4 & 0.49 & 491 & 9.6 & 0.49 \\
\hline $\begin{array}{l}\text { Female } \\
\text { Race }\end{array}$ & $12,823,107$ & 21,929 & 18,952 & 86.5 & 0.26 & 2,888 & 13.5 & 0.26 \\
\hline White & $12,980,558$ & 20,119 & 17,362 & 86.6 & 0.27 & 2,685 & 13.4 & 0.27 \\
\hline Black & $2,608,720$ & 5,554 & 4,960 & 89.6 & 0.50 & 562 & 10.4 & 0.50 \\
\hline $\begin{array}{c}\text { Other } \\
\text { Ethnicity }\end{array}$ & 958,949 & 1,631 & 1,483 & 91.6 & 0.81 & 132 & 8.4 & 0.81 \\
\hline Non-Hispanic & $15,172,660$ & 23,735 & 20,553 & 87.0 & 0.25 & 3,078 & 13.0 & 0.25 \\
\hline $\begin{array}{l}\text { Hispanic } \\
\text { Age group }\end{array}$ & $1,375,568$ & 3,569 & 3,252 & 91.0 & 0.65 & 301 & 9.0 & 0.65 \\
\hline $18-24$ & $1,725,603$ & 2,299 & 2,021 & 88.4 & 0.80 & 272 & 11.6 & 0.80 \\
\hline $25-64$ & $14,247,961$ & 23,836 & 20,790 & 87.3 & 0.24 & 2,938 & 12.7 & 0.24 \\
\hline $\begin{array}{l}\quad 65 \text { and older } \\
\text { Education }^{3}\end{array}$ & 574,664 & 1,169 & 994 & 85.1 & 1.18 & 169 & 14.9 & 1.18 \\
\hline Less than HS & $1,141,190$ & 2,376 & 2,126 & 89.3 & 0.79 & 239 & 10.7 & 0.79 \\
\hline High school & $3,582,213$ & 6,011 & 5,299 & 88.3 & 0.47 & 692 & 11.7 & 0.47 \\
\hline $\begin{array}{l}\text { More than HS } \\
\text { Insurance }\end{array}$ & $11,751,646$ & 18,800 & 16,271 & 86.9 & 0.29 & 2,441 & 13.1 & 0.29 \\
\hline Insured & $14,662,946$ & 23,754 & 20,521 & 86.7 & 0.25 & 3,130 & 13.3 & 0.25 \\
\hline Uninsured & $1,839,325$ & 3,495 & 3,236 & 92.7 & 0.54 & 242 & 7.3 & 0.54 \\
\hline
\end{tabular}

Source: Contract Report (March 2010). NORA Morbidity and Disability: The National Health Interview Survey (NHIS) $1997-2007$. Department of Epidemiology and Public Health, University of Miami School of Medicine

The estimates from this table are based on a question from the National Health Interview Survey that asked respondents "During the PAST 12 MONTHS have you had SURGERY or other surgical procedures either as an inpatient or an outpatient? This includes both major surgery and minor procedures such as setting bones or removing growths."

1 Sample size from the National Health Interview Survey for the years 1997-2007

2 Percent (prevalence) estimated from the National Health Interview Survey for the years 1997-2007

${ }_{3}^{3}$ Response categories include (1) less than High School graduate, (2) High School graduate or GED, and (3) Some college or higher education. 
Table 41. Prevalence of hospital emergency room visit during the past 12 months estimated for workers 18 years and older, All NORA sectors, National Health Interview Survey, 1997-2007

\begin{tabular}{|c|c|c|c|c|c|c|c|c|}
\hline \multirow[b]{2}{*}{ Subgroup } & \multirow{2}{*}{$\begin{array}{c}\text { US } \\
\text { Estimated } \\
\text { Worker } \\
\text { Population }\end{array}$} & \multirow{2}{*}{$\begin{array}{c}\text { NHIS } \\
\text { sample } \\
\text { size }^{1}\end{array}$} & \multicolumn{3}{|c|}{ No Visits } & \multicolumn{3}{|c|}{1 or more Visits } \\
\hline & & & Number & Percent $^{2}$ & $\begin{array}{l}\text { Standard } \\
\text { error }\end{array}$ & Number & Percent $^{2}$ & $\begin{array}{c}\text { Standard } \\
\text { error }\end{array}$ \\
\hline $\begin{array}{l}\text { All subgroups } \\
\text { Gender }\end{array}$ & $126,898,030$ & 196,924 & 161,854 & 82.4 & 0.11 & 35,070 & 17.6 & 0.11 \\
\hline Male & $68,530,792$ & 97,768 & 81,835 & 83.4 & 0.14 & 15,933 & 16.6 & 0.14 \\
\hline $\begin{array}{l}\text { Female } \\
\text { Race }\end{array}$ & $58,367,238$ & 99,156 & 80,019 & 81.2 & 0.15 & 19,137 & 18.8 & 0.15 \\
\hline White & $105,313,053$ & 157,040 & 130,438 & 82.9 & 0.12 & 26,602 & 17.1 & 0.12 \\
\hline Black & $14,056,560$ & 27,262 & 20,754 & 76.6 & 0.32 & 6,508 & 23.4 & 0.32 \\
\hline $\begin{array}{l}\text { Other } \\
\text { Ethnicity }\end{array}$ & $7,528,417$ & 12,622 & 10,662 & 85.5 & 0.39 & 1,960 & 14.5 & 0.39 \\
\hline Non-Hispanic & $111,862,532$ & 163,004 & 133,260 & 82.0 & 0.12 & 29,744 & 18.0 & 0.12 \\
\hline $\begin{array}{l}\text { Hispanic } \\
\text { Age group }\end{array}$ & $15,035,498$ & 33,920 & 28,594 & 84.8 & 0.27 & 5,326 & 15.2 & 0.27 \\
\hline $18-24$ & $16,959,193$ & 21,858 & 16,571 & 75.8 & 0.36 & 5,287 & 24.2 & 0.36 \\
\hline $25-64$ & $105,946,456$ & 167,739 & 139,210 & 83.4 & 0.11 & 28,529 & 16.6 & 0.11 \\
\hline $\begin{array}{l}\quad 65 \text { and older } \\
\text { Education }^{3}\end{array}$ & $3,992,381$ & 7,327 & 6,073 & 82.8 & 0.51 & 1,254 & 17.2 & 0.51 \\
\hline Less than HS & $14,798,890$ & 26,367 & 21,288 & 80.2 & 0.31 & 5,079 & 19.8 & 0.31 \\
\hline High school & $36,048,733$ & 54,264 & 43,936 & 81.0 & 0.19 & 10,328 & 19.0 & 0.19 \\
\hline $\begin{array}{l}\text { More than HS } \\
\text { Insurance }\end{array}$ & $75,434,176$ & 115,325 & 95,860 & 83.5 & 0.13 & 19,465 & 16.5 & 0.13 \\
\hline Insured & $106,279,655$ & 161,665 & 132,978 & 82.6 & 0.12 & 28,687 & 17.4 & 0.12 \\
\hline Uninsured & $20,282,002$ & 34,830 & 28,527 & 81.4 & 0.27 & 6,303 & 18.6 & 0.27 \\
\hline
\end{tabular}

Source: Contract Report (March 2010). NORA Morbidity and Disability: The National Health Interview Survey (NHIS) $1997-2007$. Department of Epidemiology and Public Health, University of Miami School of Medicine

The estimates from this table are based on a question from the National Health Interview Survey that asked respondents "During the PAST 12 MONTHS HOW MANY TIMES have you gone to a HOSPITAL EMERGENCY ROOM for your health?"

1 Sample size from the National Health Interview Survey for the years 1997-2007

2 Percent (prevalence) estimated from the National Health Interview Survey for the years 1997-2007

${ }^{3}$ Response categories include (1) less than High School graduate, (2) High School graduate or GED, and (3) Some college or higher education. 
Table 42. Prevalence of hospital emergency room visit during the past 12 months estimated for workers 18 years and older, Healthcare and Social Assistance sector, National Health Interview Survey, 1997-2007

\begin{tabular}{|c|c|c|c|c|c|c|c|c|}
\hline \multirow[b]{2}{*}{ Subgroup } & \multirow{2}{*}{$\begin{array}{l}\text { US } \\
\text { Estimated } \\
\text { Worker } \\
\text { Population }\end{array}$} & \multirow{2}{*}{$\begin{array}{c}\text { NHIS } \\
\text { sample } \\
\text { size }^{1}\end{array}$} & \multicolumn{3}{|c|}{ No Visits } & \multicolumn{3}{|c|}{1 or more Visits } \\
\hline & & & Number & Percent $^{2}$ & $\begin{array}{l}\text { Standard } \\
\text { error }\end{array}$ & Number & Percent $^{2}$ & $\begin{array}{c}\text { Standard } \\
\text { error }\end{array}$ \\
\hline $\begin{array}{l}\text { All subgroups } \\
\text { Gender }\end{array}$ & $16,548,227$ & 27,304 & 21,950 & 81.5 & 0.28 & 5,354 & 18.5 & 0.28 \\
\hline Male & $3,725,120$ & 5,375 & 4,493 & 84.3 & 0.55 & 882 & 15.7 & 0.55 \\
\hline $\begin{array}{l}\text { Female } \\
\text { Race }\end{array}$ & $12,823,107$ & 21,929 & 17,457 & 80.6 & 0.32 & 4,472 & 19.4 & 0.32 \\
\hline White & $12,980,558$ & 20,119 & 16,524 & 82.7 & 0.31 & 3,595 & 17.3 & 0.31 \\
\hline Black & $2,608,720$ & 5,554 & 4,078 & 74.2 & 0.76 & 1,476 & 25.8 & 0.76 \\
\hline $\begin{array}{c}\text { Other } \\
\text { Ethnicity }\end{array}$ & 958,949 & 1,631 & 1,348 & 84.3 & 0.99 & 283 & 15.7 & 0.99 \\
\hline Non-Hispanic & $15,172,660$ & 23,735 & 19,057 & 81.5 & 0.29 & 4,678 & 18.5 & 0.29 \\
\hline $\begin{array}{l}\text { Hispanic } \\
\text { Age group }\end{array}$ & $1,375,568$ & 3,569 & 2,893 & 80.7 & 0.86 & 676 & 19.3 & 0.86 \\
\hline $18-24$ & $1,725,603$ & 2,299 & 1,666 & 73.9 & 1.11 & 633 & 26.1 & 1.11 \\
\hline $25-64$ & $14,247,961$ & 23,836 & 19,312 & 82.3 & 0.29 & 4,524 & 17.7 & 0.29 \\
\hline $\begin{array}{l}\quad 65 \text { and older } \\
\text { Education }^{3}\end{array}$ & 574,664 & 1,169 & 972 & 83.9 & 1.19 & 197 & 16.1 & 1.19 \\
\hline Less than HS & $1,141,190$ & 2,376 & 1,781 & 75.5 & 1.07 & 595 & 24.5 & 1.07 \\
\hline High school & $3,582,213$ & 6,011 & 4,744 & 80.0 & 0.58 & 1,267 & 20.0 & 0.58 \\
\hline $\begin{array}{l}\text { More than HS } \\
\text { Insurance }\end{array}$ & $11,751,646$ & 18,800 & 15,331 & 82.5 & 0.32 & 3,469 & 17.5 & 0.32 \\
\hline Insured & $14,662,946$ & 23,754 & 19,173 & 81.8 & 0.29 & 4,581 & 18.2 & 0.29 \\
\hline Uninsured & $1,839,325$ & 3,495 & 2,731 & 79.1 & 0.82 & 764 & 20.9 & 0.82 \\
\hline
\end{tabular}

Source: Contract Report (March 2010). NORA Morbidity and Disability: The National Health Interview Survey (NHIS) $1997-2007$. Department of Epidemiology and Public Health, University of Miami School of Medicine

The estimates from this table are based on a question from the National Health Interview Survey that asked respondents "During the PAST 12 MONTHS HOW MANY TIMES have you gone to a HOSPITAL EMERGENCY ROOM for your health?"

1 Sample size from the National Health Interview Survey for the years 1997-2007

2 Percent (prevalence) estimated from the National Health Interview Survey for the years 1997-2007

${ }^{3}$ Response categories include (1) less than High School graduate, (2) High School graduate or GED, and (3) Some college or higher education. 


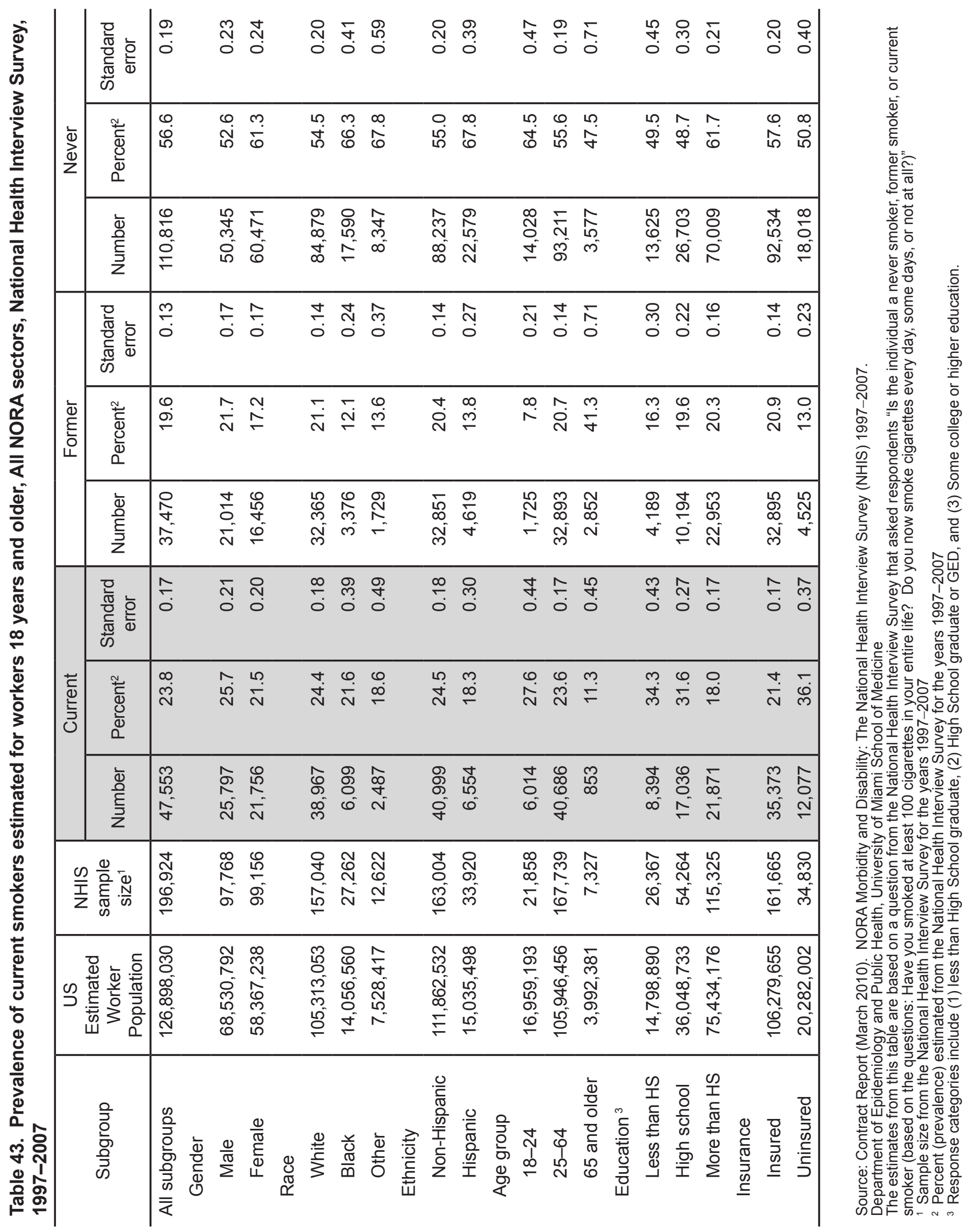




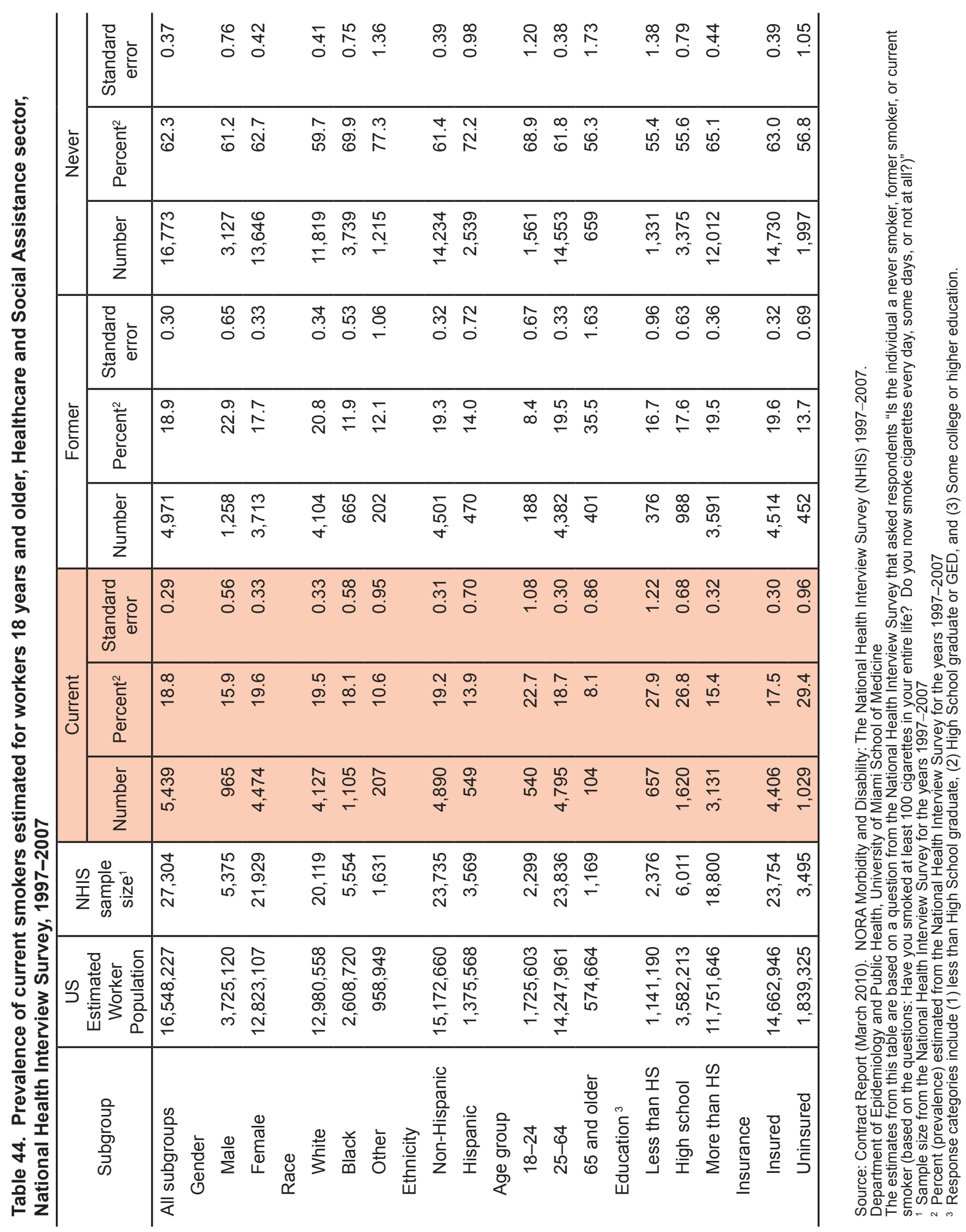




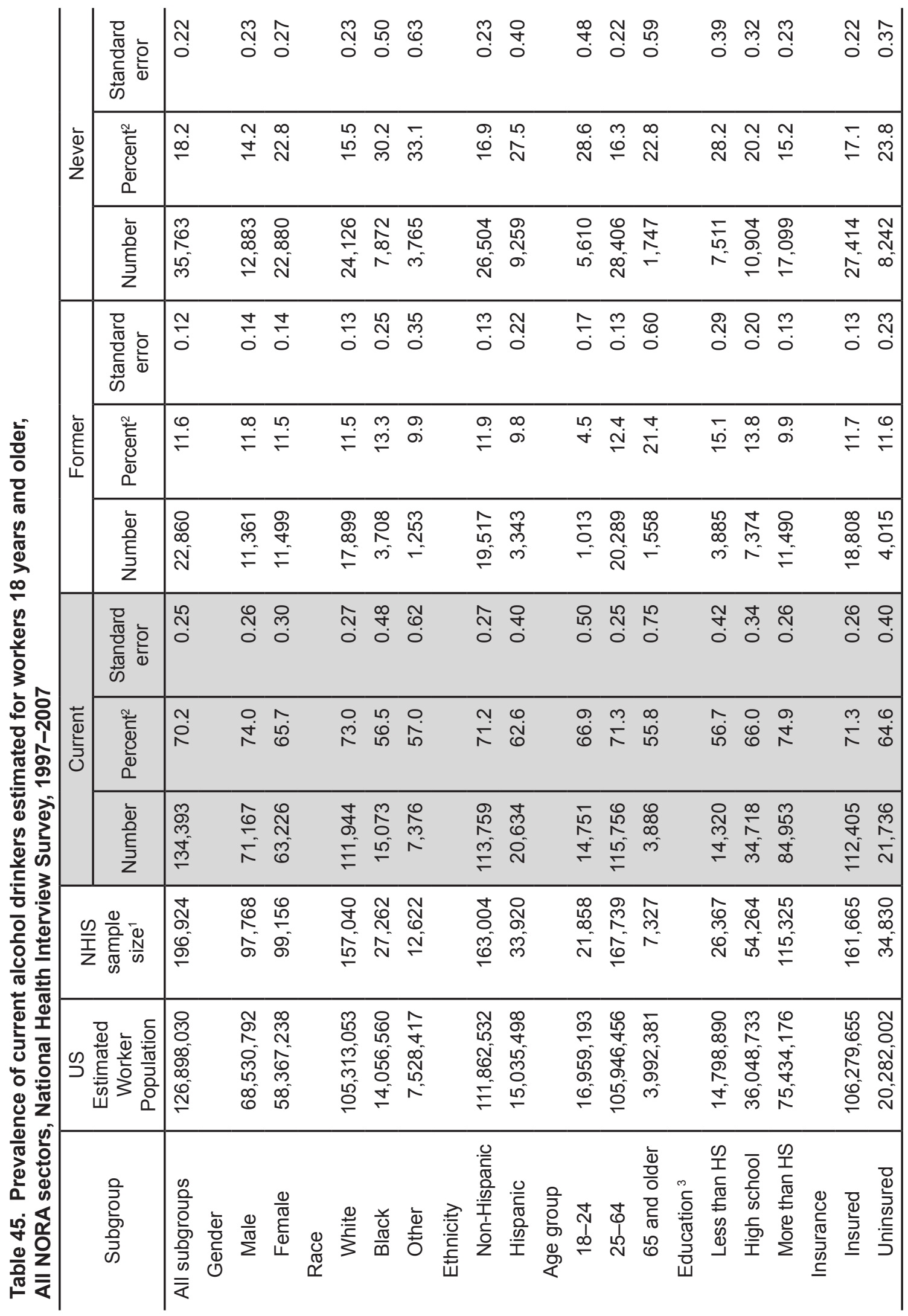

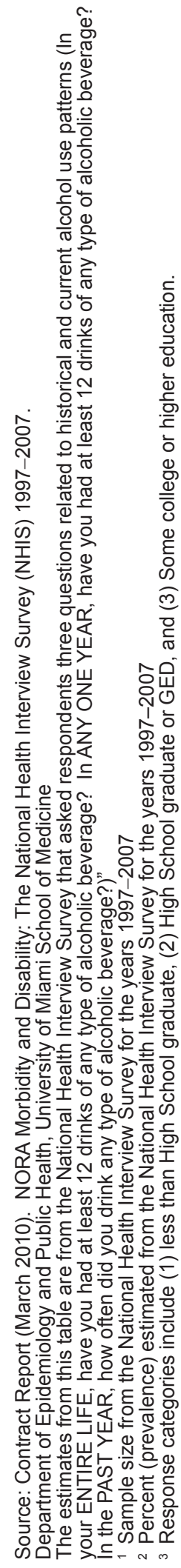




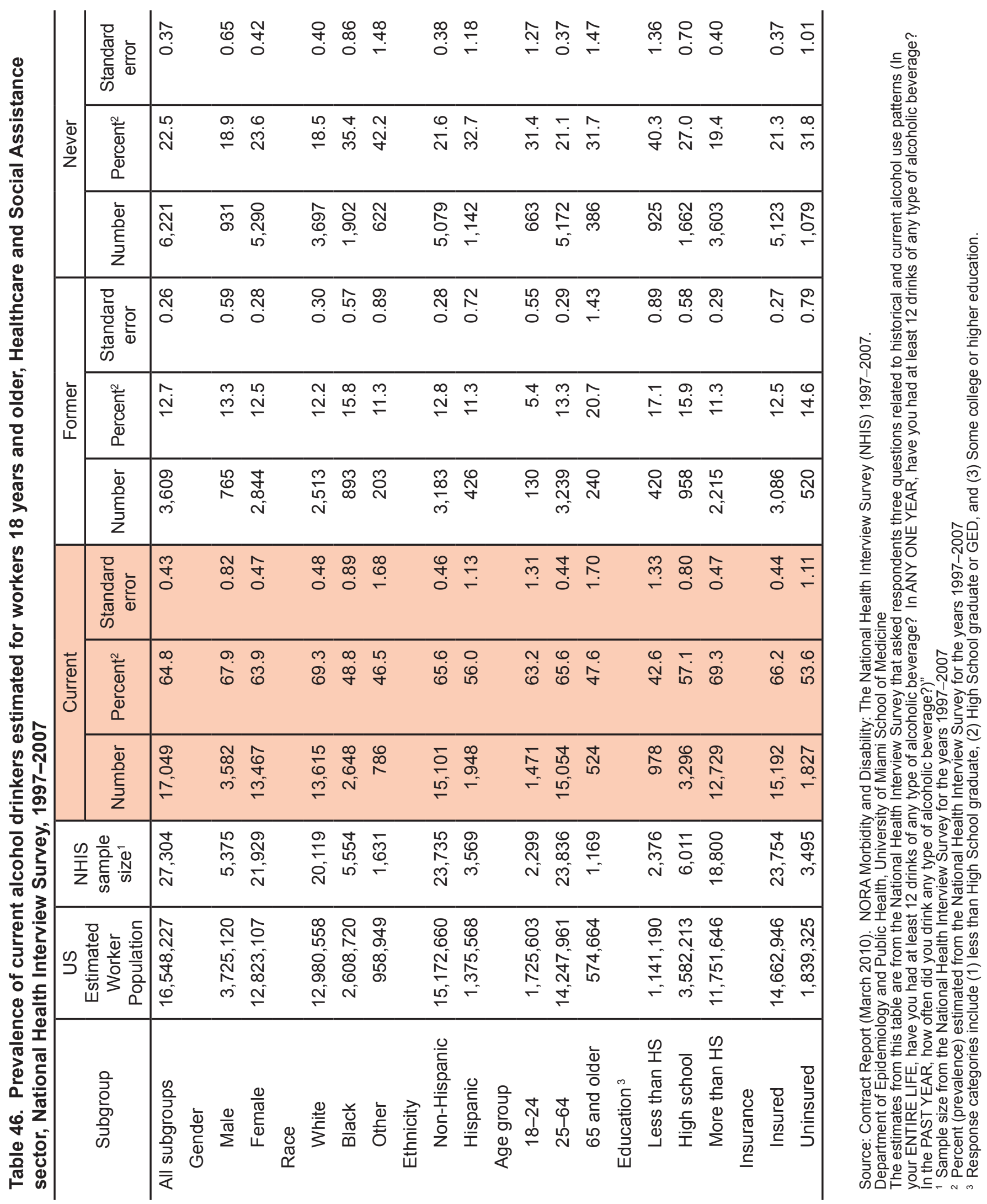




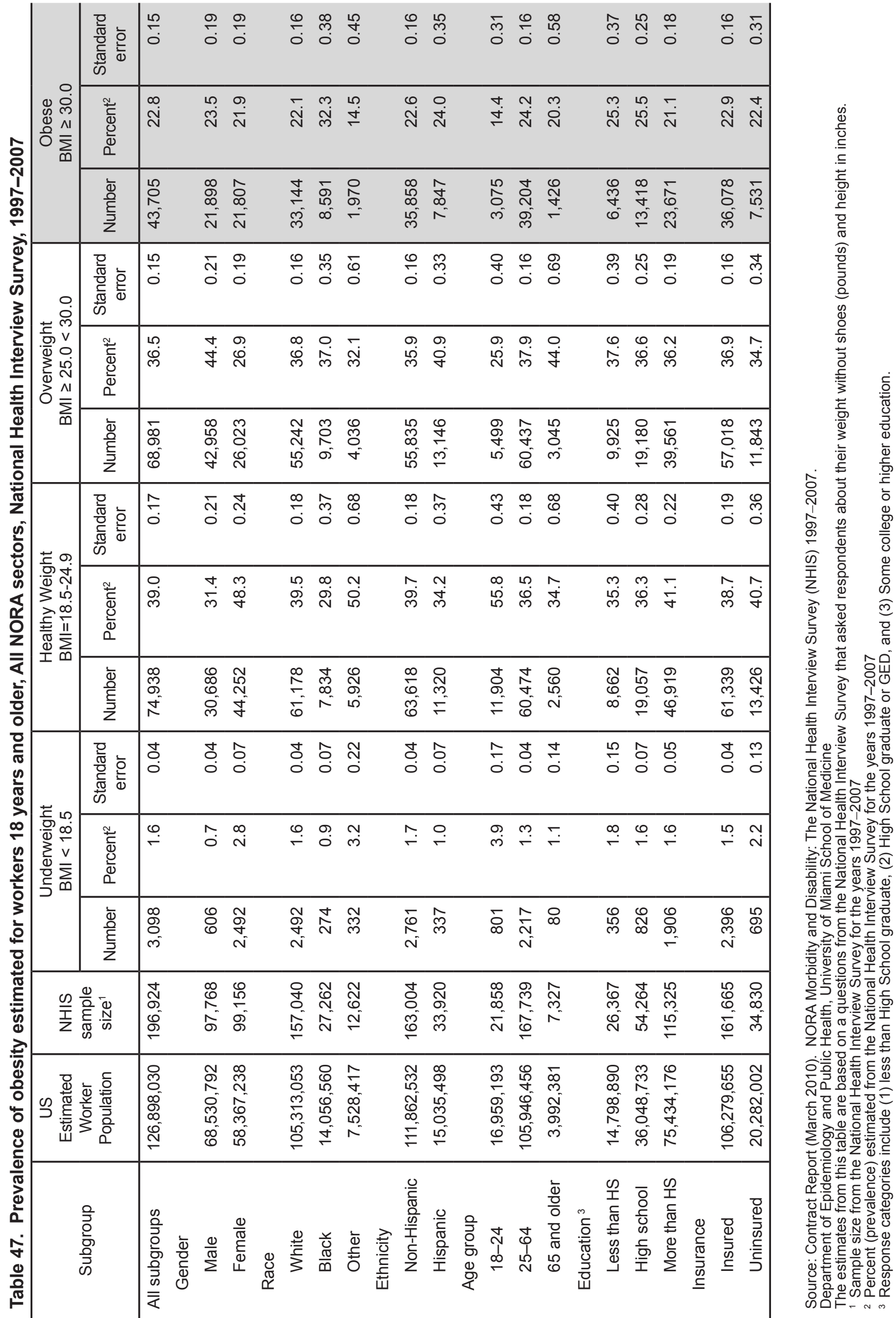




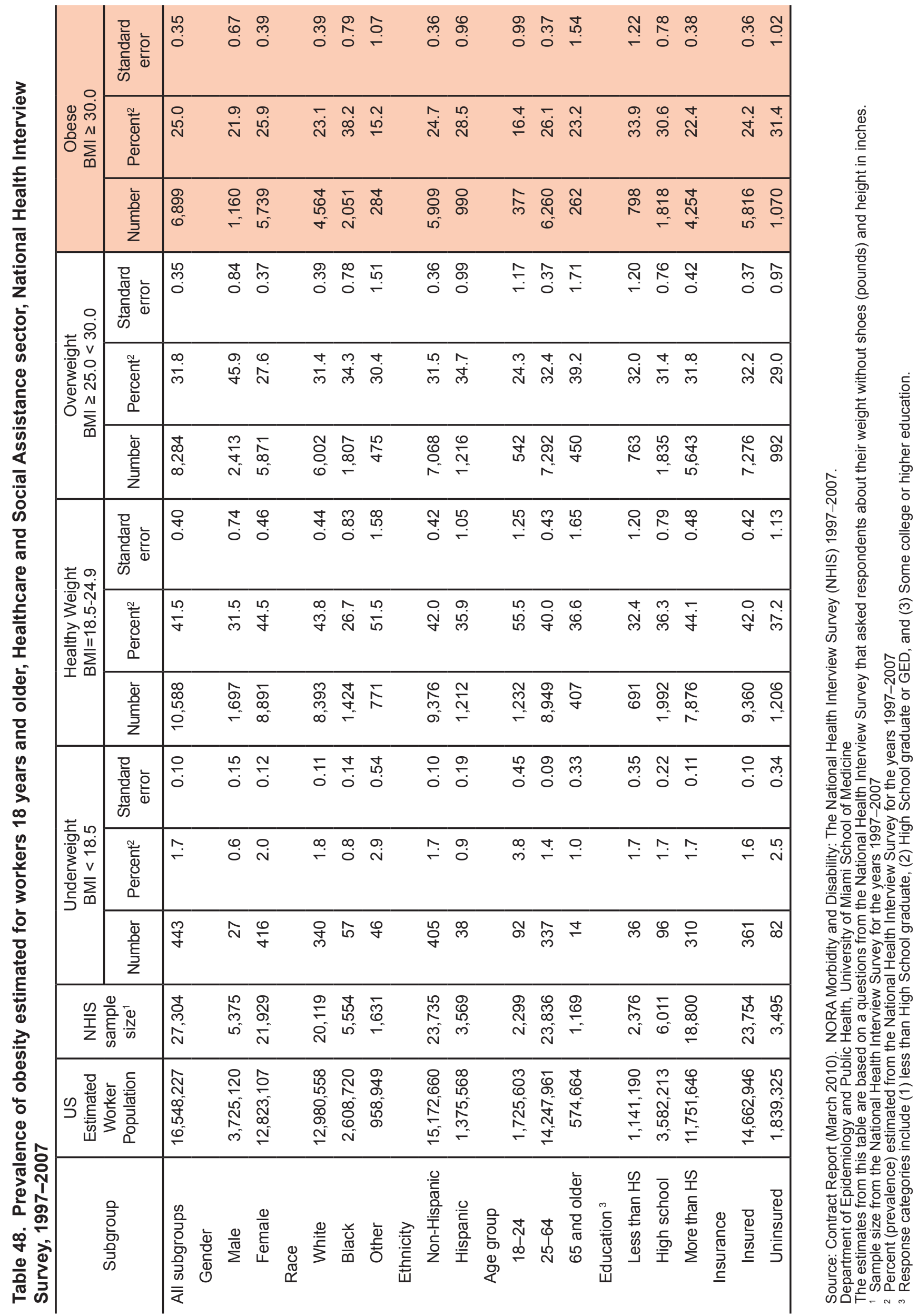


Table 49. Prevalence of not meeting CDC recommended leisure time levels of physical activity estimated for workers 18 years and older, All NORA sectors, National Health Interview Survey, 1997-2007

\begin{tabular}{|c|c|c|c|c|c|c|c|c|}
\hline \multirow[b]{2}{*}{ Subgroup } & \multirow{2}{*}{$\begin{array}{l}\text { US } \\
\text { Estimated } \\
\text { Worker } \\
\text { Population }\end{array}$} & \multirow{2}{*}{$\begin{array}{l}\text { NHIS } \\
\text { sample } \\
\text { size }^{1}\end{array}$} & \multicolumn{3}{|c|}{ Meets Guideline } & \multicolumn{3}{|c|}{ Does Not Meet Guideline } \\
\hline & & & Number & Percent $^{2}$ & $\begin{array}{l}\text { Standard } \\
\text { error }\end{array}$ & Number & Percent $^{2}$ & $\begin{array}{l}\text { Standard } \\
\text { error }\end{array}$ \\
\hline $\begin{array}{l}\text { All subgroups } \\
\text { Gender }\end{array}$ & $126,898,030$ & 196,924 & 60,942 & 34.1 & 0.22 & 121,354 & 65.9 & 0.22 \\
\hline Male & $68,530,792$ & 97,768 & 32,283 & 36.0 & 0.25 & 57,891 & 64.0 & 0.25 \\
\hline $\begin{array}{l}\text { Female } \\
\text { Race }\end{array}$ & $58,367,238$ & 99,156 & 28,659 & 31.9 & 0.25 & 63,463 & 68.1 & 0.25 \\
\hline White & $105,313,053$ & 157,040 & 50,402 & 35.2 & 0.23 & 94,906 & 64.8 & 0.23 \\
\hline Black & $14,056,560$ & 27,262 & 7,030 & 28.4 & 0.44 & 18,289 & 71.6 & 0.44 \\
\hline $\begin{array}{c}\text { Other } \\
\text { Ethnicity }\end{array}$ & $7,528,417$ & 12,622 & 3,510 & 29.9 & 0.59 & 8,159 & 70.1 & 0.59 \\
\hline Non-Hispanic & $111,862,532$ & 163,004 & 52,997 & 35.3 & 0.23 & 97,494 & 64.7 & 0.23 \\
\hline $\begin{array}{l}\text { Hispanic } \\
\text { Age group }\end{array}$ & $15,035,498$ & 33,920 & 7,945 & 25.3 & 0.35 & 23,860 & 74.7 & 0.35 \\
\hline $18-24$ & $16,959,193$ & 21,858 & 7,828 & 39.2 & 0.50 & 12,523 & 60.8 & 0.50 \\
\hline $25-64$ & $105,946,456$ & 167,739 & 51,416 & 33.6 & 0.22 & 103,728 & 66.4 & 0.22 \\
\hline $\begin{array}{l}\quad 65 \text { and older } \\
\text { Education }^{3}\end{array}$ & $3,992,381$ & 7,327 & 1,698 & 25.8 & 0.63 & 5,103 & 74.2 & 0.63 \\
\hline Less than HS & $14,798,890$ & 26,367 & 4,718 & 21.1 & 0.36 & 19,715 & 78.9 & 0.36 \\
\hline High school & $36,048,733$ & 54,264 & 13,347 & 27.4 & 0.31 & 36,585 & 72.6 & 0.31 \\
\hline $\begin{array}{l}\text { More than HS } \\
\text { Insurance }\end{array}$ & $75,434,176$ & 115,325 & 42,721 & 40.0 & 0.24 & 64,408 & 60.0 & 0.24 \\
\hline Insured & $106,279,655$ & 161,665 & 52,241 & 35.4 & 0.22 & 97,328 & 64.6 & 0.22 \\
\hline Uninsured & $20,282,002$ & 34,830 & 8,570 & 27.2 & 0.37 & 23,752 & 72.8 & 0.37 \\
\hline
\end{tabular}

Source: Contract Report (March 2010). NORA Morbidity and Disability: The National Health Interview Survey (NHIS) $1997-2007$. Department of Epidemiology and Public Health, University of Miami School of Medicine

The estimates from this table are based on four question from the National Health Interview Survey that permits one to assess whether respondents met CDC Healthy People 2010 recommendations for leisure time physical activity (i.e., engaged in light or moderate activity $\geq 30$ minutes $\geq 5$ times per week or rigorous activity $\geq 20$ minutes $\geq 3$ times per week or both. The four questions sought responses on (1) frequency of light/moderate activity (times per week); (2) duration of light/moderate activity (in minutes); (3) frequency of vigorous activity; and (4) duration of vigorous activity. See Adams PF, Barnes PM. Summary health statistics for the U.S. population: National Health Interview Survey, 2004. National Center for Health Statistics.

Vital Health Stat 10 (229). 2006. DHHS Publication No. (PHS) 2006-1557, Series 10, No. 229.

1 Sample size from the National Health Interview Survey for the years 1997-2007

2 Percent (prevalence) estimated from the National Health Interview Survey for the years 1997-2007

${ }^{3}$ Response categories include (1) less than High School graduate, (2) High School graduate or GED, and (3) Some college or higher education. 
Table 50. Prevalence of not meeting CDC recommended leisure time levels of physical activity estimated for workers 18 years and older, Healthcare and Social Assistance sector, National Health Interview Survey, 1997-2007

\begin{tabular}{|c|c|c|c|c|c|c|c|c|}
\hline \multirow[b]{2}{*}{ Subgroup } & \multirow{2}{*}{$\begin{array}{c}\text { US } \\
\text { Estimated } \\
\text { Worker } \\
\text { Population }\end{array}$} & \multirow{2}{*}{$\begin{array}{c}\text { NHIS } \\
\text { sample } \\
\text { size }^{1}\end{array}$} & \multicolumn{3}{|c|}{ Meets Guideline } & \multicolumn{3}{|c|}{ Does Not Meet Guideline } \\
\hline & & & Number & Percent $^{2}$ & $\begin{array}{l}\text { Standard } \\
\text { error }\end{array}$ & Number & Percent $^{2}$ & $\begin{array}{c}\text { Standard } \\
\text { error }\end{array}$ \\
\hline $\begin{array}{l}\text { All subgroups } \\
\text { Gender }\end{array}$ & $16,548,227$ & 27,304 & 8,414 & 34.4 & 0.38 & 16,925 & 65.6 & 0.38 \\
\hline Male & $3,725,120$ & 5,375 & 2,031 & 41.2 & 0.81 & 2,933 & 58.8 & 0.81 \\
\hline $\begin{array}{l}\text { Female } \\
\text { Race }\end{array}$ & $12,823,107$ & 21,929 & 6,383 & 32.4 & 0.42 & 13,992 & 67.6 & 0.42 \\
\hline White & $12,980,558$ & 20,119 & 6,631 & 36.3 & 0.42 & 12,052 & 63.7 & 0.42 \\
\hline Black & $2,608,720$ & 5,554 & 1,328 & 26.6 & 0.80 & 3,824 & 73.4 & 0.80 \\
\hline $\begin{array}{c}\text { Other } \\
\text { Ethnicity }\end{array}$ & 958,949 & 1,631 & 455 & 29.2 & 1.42 & 1,049 & 70.8 & 1.42 \\
\hline Non-Hispanic & $15,172,660$ & 23,735 & 7,483 & 35.0 & 0.40 & 14,505 & 65.0 & 0.40 \\
\hline $\begin{array}{l}\text { Hispanic } \\
\text { Age group }\end{array}$ & $1,375,568$ & 3,569 & 931 & 27.6 & 1.00 & 2,420 & 72.4 & 1.00 \\
\hline $18-24$ & $1,725,603$ & 2,299 & 802 & 37.7 & 1.32 & 1,346 & 62.3 & 1.32 \\
\hline $25-64$ & $14,247,961$ & 23,836 & 7,355 & 34.3 & 0.40 & 14,754 & 65.7 & 0.40 \\
\hline $\begin{array}{l}\quad 65 \text { and older } \\
\text { Education }^{3}\end{array}$ & 574,664 & 1,169 & 257 & 24.8 & 1.58 & 825 & 75.2 & 1.58 \\
\hline Less than HS & $1,141,190$ & 2,376 & 407 & 19.2 & 1.04 & 1,790 & 80.8 & 1.04 \\
\hline High school & $3,582,213$ & 6,011 & 1,390 & 26.0 & 0.75 & 4,177 & 74.0 & 0.75 \\
\hline $\begin{array}{l}\text { More than HS } \\
\text { Insurance }\end{array}$ & $11,751,646$ & 18,800 & 6,599 & 38.4 & 0.45 & 10,880 & 61.6 & 0.45 \\
\hline Insured & $14,662,946$ & 23,754 & 7,510 & 35.1 & 0.40 & 14,537 & 64.9 & 0.40 \\
\hline Uninsured & $1,839,325$ & 3,495 & 888 & 28.1 & 1.03 & 2,350 & 71.9 & 1.03 \\
\hline
\end{tabular}

Source: Contract Report (March 2010). NORA Morbidity and Disability: The National Health Interview Survey (NHIS) $1997-2007$. Department of Epidemiology and Public Health, University of Miami School of Medicine

The estimates from this table are based on four question from the National Health Interview Survey that permits one to assess whether respondents met CDC Healthy People 2010 recommendations for leisure time physical activity (i.e., engaged in light or moderate activity $\geq 30$ minutes $\geq 5$ times per week or rigorous activity $\geq 20$ minutes $\geq 3$ times per week or both. The four questions sought responses on (1) frequency of light/moderate activity (times per week); (2) duration of light/moderate activity (in minutes); (3) frequency of vigorous activity; and (4) duration of vigorous activity. See Adams PF, Barnes PM. Summary health statistics for the U.S. population: National Health Interview Survey, 2004. National Center for Health Statistics.

Vital Health Stat 10 (229). 2006. DHHS Publication No. (PHS) 2006-1557, Series 10, No. 229

1 Sample size from the National Health Interview Survey for the years 1997-2007

2 Percent (prevalence) estimated from the National Health Interview Survey for the years 1997-2007

${ }^{3}$ Response categories include (1) less than High School graduate, (2) High School graduate or GED, and (3) Some college or higher education. 
Table 51. Prevalence of lifetime HIV test estimated for workers 18 years and older, All NORA sectors, National Health Interview Survey, 1997-2007

\begin{tabular}{|c|c|c|c|c|c|c|c|c|}
\hline \multirow[b]{2}{*}{ Subgroup } & \multirow{2}{*}{$\begin{array}{c}\text { US } \\
\text { Estimated } \\
\text { Worker } \\
\text { Population }\end{array}$} & \multirow{2}{*}{$\begin{array}{c}\text { NHIS } \\
\text { sample } \\
\text { size }^{1}\end{array}$} & \multicolumn{3}{|c|}{ Yes } & \multicolumn{3}{|c|}{ No } \\
\hline & & & Number & Percent $^{2}$ & $\begin{array}{l}\text { Standard } \\
\text { error }\end{array}$ & Number & Percent $^{2}$ & $\begin{array}{l}\text { Standard } \\
\text { error }\end{array}$ \\
\hline $\begin{array}{l}\text { All subgroups } \\
\text { Gender }\end{array}$ & $126,898,030$ & 196,924 & 76,067 & 37.8 & 0.20 & 114,789 & 62.2 & 0.20 \\
\hline Male & $68,530,792$ & 97,768 & 34,778 & 35.4 & 0.25 & 59,762 & 64.6 & 0.25 \\
\hline $\begin{array}{l}\text { Female } \\
\text { Race }\end{array}$ & $58,367,238$ & 99,156 & 41,289 & 40.6 & 0.24 & 55,027 & 59.4 & 0.24 \\
\hline White & $105,313,053$ & 157,040 & 56,355 & 35.4 & 0.21 & 95,852 & 64.6 & 0.21 \\
\hline Black & $14,056,560$ & 27,262 & 14,858 & 55.5 & 0.48 & 11,578 & 44.5 & 0.48 \\
\hline $\begin{array}{c}\text { Other } \\
\text { Ethnicity }\end{array}$ & $7,528,417$ & 12,622 & 4,854 & 37.8 & 0.58 & 7,359 & 62.2 & 0.58 \\
\hline Non-Hispanic & $111,862,532$ & 163,004 & 62,707 & 37.6 & 0.21 & 95,190 & 62.4 & 0.21 \\
\hline $\begin{array}{l}\text { Hispanic } \\
\text { Age group }\end{array}$ & $15,035,498$ & 33,920 & 13,360 & 38.8 & 0.44 & 19,599 & 61.2 & 0.44 \\
\hline $18-24$ & $16,959,193$ & 21,858 & 8,019 & 33.0 & 0.44 & 13,325 & 67.0 & 0.44 \\
\hline $25-64$ & $105,946,456$ & 167,739 & 67,082 & 39.5 & 0.22 & 95,482 & 60.5 & 0.22 \\
\hline $\begin{array}{l}\quad 65 \text { and older } \\
\text { Education }^{3}\end{array}$ & $3,992,381$ & 7,327 & 966 & 13.4 & 0.49 & 5,982 & 86.6 & 0.49 \\
\hline Less than HS & $14,798,890$ & 26,367 & 8,753 & 32.3 & 0.42 & 16,760 & 67.7 & 0.42 \\
\hline High school & $36,048,733$ & 54,264 & 18,821 & 33.5 & 0.29 & 33,719 & 66.5 & 0.29 \\
\hline $\begin{array}{l}\text { More than HS } \\
\text { Insurance }\end{array}$ & $75,434,176$ & 115,325 & 48,268 & 40.9 & 0.23 & 63,743 & 59.1 & 0.23 \\
\hline Insured & $106,279,655$ & 161,665 & 62,010 & 37.5 & 0.22 & 94,601 & 62.5 & 0.22 \\
\hline Uninsured & $20,282,002$ & 34,830 & 13,916 & 39.3 & 0.38 & 19,940 & 60.7 & 0.38 \\
\hline
\end{tabular}

Source: Contract Report (March 2010). NORA Morbidity and Disability: The National Health Interview Survey (NHIS) $1997-2007$. Department of Epidemiology and Public Health, University of Miami School of Medicine

The estimates from this table are based on a question from the National Health Interview Survey that asked respondents "Have you ever been tested for HIV?"

1 Sample size from the National Health Interview Survey for the years 1997-2007

2 Percent (prevalence) estimated from the National Health Interview Survey for the years 1997-2007

3 Response categories include (1) less than High School graduate, (2) High School graduate or GED, and (3) Some college or higher education. 
Table 52. Prevalence of lifetime HIV test estimated for workers 18 years and older, Healthcare and Social Assistance sector, National Health Interview Survey, 1997-2007

\begin{tabular}{|c|c|c|c|c|c|c|c|c|}
\hline \multirow[b]{2}{*}{ Subgroup } & \multirow{2}{*}{$\begin{array}{l}\text { US } \\
\text { Estimated } \\
\text { Worker } \\
\text { Population }\end{array}$} & \multirow{2}{*}{$\begin{array}{c}\text { NHIS } \\
\text { sample } \\
\text { size }^{1}\end{array}$} & \multicolumn{3}{|c|}{ Yes } & \multicolumn{3}{|c|}{ No } \\
\hline & & & Number & Percent $^{2}$ & $\begin{array}{l}\text { Standard } \\
\text { error }\end{array}$ & Number & Percent $^{2}$ & $\begin{array}{c}\text { Standard } \\
\text { error }\end{array}$ \\
\hline $\begin{array}{l}\text { All subgroups } \\
\text { Gender }\end{array}$ & $16,548,227$ & 27,304 & 13,027 & 47.0 & 0.39 & 13,616 & 53.0 & 0.39 \\
\hline Male & $3,725,120$ & 5,375 & 2,536 & 46.7 & 0.81 & 2,685 & 53.3 & 0.81 \\
\hline $\begin{array}{l}\text { Female } \\
\text { Race }\end{array}$ & $12,823,107$ & 21,929 & 10,491 & 47.0 & 0.43 & 10,931 & 53.0 & 0.43 \\
\hline White & $12,980,558$ & 20,119 & 8,900 & 44.0 & 0.43 & 10,752 & 56.0 & 0.43 \\
\hline Black & $2,608,720$ & 5,554 & 3,314 & 60.8 & 0.78 & 2,094 & 39.2 & 0.78 \\
\hline $\begin{array}{c}\text { Other } \\
\text { Ethnicity }\end{array}$ & 958,949 & 1,631 & 813 & 49.3 & 1.54 & 770 & 50.7 & 1.54 \\
\hline Non-Hispanic & $15,172,660$ & 23,735 & 11,167 & 46.4 & 0.41 & 11,992 & 53.6 & 0.41 \\
\hline $\begin{array}{l}\text { Hispanic } \\
\text { Age group }\end{array}$ & $1,375,568$ & 3,569 & 1,860 & 53.1 & 1.21 & 1,624 & 46.9 & 1.21 \\
\hline $18-24$ & $1,725,603$ & 2,299 & 1,095 & 42.5 & 1.37 & 1,157 & 57.5 & 1.37 \\
\hline $25-64$ & $14,247,961$ & 23,836 & 11,745 & 48.7 & 0.41 & 11,533 & 51.3 & 0.41 \\
\hline $\begin{array}{l}\quad 65 \text { and older } \\
\text { Education }^{3}\end{array}$ & 574,664 & 1,169 & 187 & 16.8 & 1.31 & 926 & 83.2 & 1.31 \\
\hline Less than HS & $1,141,190$ & 2,376 & 987 & 40.2 & 1.29 & 1,314 & 59.8 & 1.29 \\
\hline High school & $3,582,213$ & 6,011 & 2,463 & 39.0 & 0.79 & 3,399 & 61.0 & 0.79 \\
\hline $\begin{array}{l}\text { More than HS } \\
\text { Insurance }\end{array}$ & $11,751,646$ & 18,800 & 9,545 & 50.1 & 0.45 & 8,837 & 49.9 & 0.45 \\
\hline Insured & $14,662,946$ & 23,754 & 11,243 & 46.7 & 0.42 & 11,936 & 53.3 & 0.42 \\
\hline Uninsured & $1,839,325$ & 3,495 & 1,757 & 49.3 & 1.04 & 1,655 & 50.7 & 1.04 \\
\hline
\end{tabular}

Source: Contract Report (March 2010). NORA Morbidity and Disability: The National Health Interview Survey (NHIS) $1997-2007$. Department of Epidemiology and Public Health, University of Miami School of Medicine

The estimates from this table are based on a question from the National Health Interview Survey that asked respondents "Have you ever been tested for HIV?"

1 Sample size from the National Health Interview Survey for the years 1997-2007

2 Percent (prevalence) estimated from the National Health Interview Survey for the years 1997-2007

3 Response categories include (1) less than High School graduate, (2) High School graduate or GED, and (3) Some college or higher education. 
Table 53. Prevalence of not receiving an influenza vaccination during the past 12 months estimated for workers 18 years and older, All NORA sectors, National Health Interview Survey, 1997-2007

\begin{tabular}{|c|c|c|c|c|c|c|c|c|}
\hline \multirow[b]{2}{*}{ Subgroup } & \multirow{2}{*}{$\begin{array}{c}\text { US } \\
\text { Estimated } \\
\text { Worker } \\
\text { Population }\end{array}$} & \multirow{2}{*}{$\begin{array}{c}\text { NHIS } \\
\text { sample } \\
\text { size }^{1}\end{array}$} & \multicolumn{3}{|c|}{ Yes } & \multicolumn{3}{|c|}{ No } \\
\hline & & & Number & Percent $^{2}$ & $\begin{array}{l}\text { Standard } \\
\text { error }\end{array}$ & Number & Percent $^{2}$ & $\begin{array}{l}\text { Standard } \\
\text { error }\end{array}$ \\
\hline $\begin{array}{l}\text { All subgroups } \\
\text { Gender }\end{array}$ & $126,898,030$ & 196,924 & 40,401 & 20.9 & 0.15 & 154,881 & 79.1 & 0.15 \\
\hline Male & $68,530,792$ & 97,768 & 17,898 & 18.7 & 0.18 & 79,022 & 81.3 & 0.18 \\
\hline $\begin{array}{l}\text { Female } \\
\text { Race }\end{array}$ & $58,367,238$ & 99,156 & 22,503 & 23.5 & 0.21 & 75,859 & 76.5 & 0.21 \\
\hline White & $105,313,053$ & 157,040 & 33,373 & 21.5 & 0.17 & 122,428 & 78.5 & 0.17 \\
\hline Black & $14,056,560$ & 27,262 & 4,574 & 16.6 & 0.29 & 22,399 & 83.4 & 0.29 \\
\hline $\begin{array}{c}\text { Other } \\
\text { Ethnicity }\end{array}$ & $7,528,417$ & 12,622 & 2,454 & 20.4 & 0.50 & 10,054 & 79.6 & 0.50 \\
\hline Non-Hispanic & $111,862,532$ & 163,004 & 35,693 & 21.9 & 0.16 & 125,950 & 78.1 & 0.16 \\
\hline $\begin{array}{l}\text { Hispanic } \\
\text { Age group }\end{array}$ & $15,035,498$ & 33,920 & 4,708 & 13.7 & 0.27 & 28,931 & 86.3 & 0.27 \\
\hline $18-24$ & $16,959,193$ & 21,858 & 2,770 & 12.9 & 0.29 & 18,883 & 87.1 & 0.29 \\
\hline $25-64$ & $105,946,456$ & 167,739 & 33,669 & 20.8 & 0.16 & 132,706 & 79.2 & 0.16 \\
\hline $\begin{array}{l}\quad 65 \text { and older } \\
\text { Education }^{3}\end{array}$ & $3,992,381$ & 7,327 & 3,962 & 57.1 & 0.68 & 3,292 & 42.9 & 0.68 \\
\hline Less than HS & $14,798,890$ & 26,367 & 3,876 & 14.6 & 0.30 & 22,262 & 85.4 & 0.30 \\
\hline High school & $36,048,733$ & 54,264 & 10,007 & 18.6 & 0.22 & 43,797 & 81.4 & 0.22 \\
\hline $\begin{array}{l}\text { More than HS } \\
\text { Insurance }\end{array}$ & $75,434,176$ & 115,325 & 26,356 & 23.3 & 0.19 & 88,109 & 76.7 & 0.19 \\
\hline Insured & $106,279,655$ & 161,665 & 37,134 & 23.2 & 0.17 & 123,190 & 76.8 & 0.17 \\
\hline Uninsured & $20,282,002$ & 34,830 & 3,205 & 9.2 & 0.19 & 31,343 & 90.8 & 0.19 \\
\hline
\end{tabular}

Source: Contract Report (March 2010). NORA Morbidity and Disability: The National Health Interview Survey (NHIS) $1997-2007$. Department of Epidemiology and Public Health, University of Miami School of Medicine

The estimates from this table are based on a question from the National Health Interview Survey that asked respondents "During the PAST 12 MONTHS, have you had a flu shot? A flu shot is usually given in the fall and protects against influenza for the flu season."

1 Sample size from the National Health Interview Survey for the years 1997-2007

2 Percent (prevalence) estimated from the National Health Interview Survey for the years 1997-2007

${ }_{3}$ Response categories include (1) less than High School graduate, (2) High School graduate or GED, and (3) Some college or higher education. 
Table 54. Prevalence of not receiving an influenza vaccination during the past 12 months estimated for workers 18 years and older, Healthcare and Social Assistance sector, National Health Interview Survey, 1997-2007

\begin{tabular}{|c|c|c|c|c|c|c|c|c|}
\hline \multirow[b]{2}{*}{ Subgroup } & \multirow{2}{*}{$\begin{array}{c}\text { US } \\
\text { Estimated } \\
\text { Worker } \\
\text { Population }\end{array}$} & \multirow{2}{*}{$\begin{array}{c}\text { NHIS } \\
\text { sample } \\
\text { size }^{1}\end{array}$} & \multicolumn{3}{|c|}{ Yes } & \multicolumn{3}{|c|}{ No } \\
\hline & & & Number & Percent $^{2}$ & $\begin{array}{l}\text { Standard } \\
\text { error }\end{array}$ & Number & Percent ${ }^{2}$ & $\begin{array}{c}\text { Standard } \\
\text { error }\end{array}$ \\
\hline $\begin{array}{l}\text { All subgroups } \\
\text { Gender }\end{array}$ & $16,548,227$ & 27,304 & 9,206 & 35.5 & 0.39 & 17,883 & 64.5 & 0.39 \\
\hline Male & $3,725,120$ & 5,375 & 1,938 & 36.9 & 0.80 & 3,387 & 63.1 & 0.80 \\
\hline $\begin{array}{l}\text { Female } \\
\text { Race }\end{array}$ & $12,823,107$ & 21,929 & 7,268 & 35.1 & 0.44 & 14,496 & 64.9 & 0.44 \\
\hline White & $12,980,558$ & 20,119 & 7,319 & 37.7 & 0.44 & 12,660 & 62.3 & 0.44 \\
\hline Black & $2,608,720$ & 5,554 & 1,365 & 25.0 & 0.74 & 4,135 & 75.0 & 0.74 \\
\hline $\begin{array}{l}\text { Other } \\
\text { Ethnicity }\end{array}$ & 958,949 & 1,631 & 522 & 34.1 & 1.58 & 1,088 & 65.9 & 1.58 \\
\hline Non-Hispanic & $15,172,660$ & 23,735 & 8,260 & 36.2 & 0.41 & 15,283 & 63.8 & 0.41 \\
\hline $\begin{array}{l}\text { Hispanic } \\
\text { Age group }\end{array}$ & $1,375,568$ & 3,569 & 946 & 27.7 & 1.07 & 2,600 & 72.3 & 1.07 \\
\hline $18-24$ & $1,725,603$ & 2,299 & 554 & 25.5 & 1.12 & 1,728 & 74.5 & 1.12 \\
\hline $25-64$ & $14,247,961$ & 23,836 & 7,971 & 35.7 & 0.42 & 15,678 & 64.3 & 0.42 \\
\hline $\begin{array}{l}\quad 65 \text { and older } \\
\text { Education }^{3}\end{array}$ & 574,664 & 1,169 & 681 & 61.6 & 1.57 & 477 & 38.4 & 1.57 \\
\hline Less than HS & $1,141,190$ & 2,376 & 659 & 28.8 & 1.19 & 1,696 & 71.2 & 1.19 \\
\hline High school & $3,582,213$ & 6,011 & 1,842 & 32.3 & 0.75 & 4,126 & 67.7 & 0.75 \\
\hline $\begin{array}{l}\text { More than HS } \\
\text { Insurance }\end{array}$ & $11,751,646$ & 18,800 & 6,672 & 37.2 & 0.47 & 11,992 & 62.8 & 0.47 \\
\hline Insured & $14,662,946$ & 23,754 & 8,533 & 37.4 & 0.42 & 15,034 & 62.6 & 0.42 \\
\hline Uninsured & $1,839,325$ & 3,495 & 658 & 20.6 & 0.81 & 2,811 & 79.4 & 0.81 \\
\hline
\end{tabular}

Source: Contract Report (March 2010). NORA Morbidity and Disability: The National Health Interview Survey (NHIS) $1997-2007$. Department of Epidemiology and Public Health, University of Miami School of Medicine

The estimates from this table are based on a question from the National Health Interview Survey that asked respondents "During the PAST 12 MONTHS, have you had a flu shot? A flu shot is usually given in the fall and protects against influenza for the flu season."

1 Sample size from the National Health Interview Survey for the years 1997-2007

2 Percent (prevalence) estimated from the National Health Interview Survey for the years 1997-2007

3 Response categories include (1) less than High School graduate, (2) High School graduate or GED, and (3) Some college or higher education. 
Table 55. Prevalence of never receiving a pneumococcal vaccination estimated for workers 60 years and older, All NORA sectors, National Health Interview Survey, 1997-2007

\begin{tabular}{|c|c|c|c|c|c|c|c|c|}
\hline \multirow[b]{2}{*}{ Subgroup } & \multirow{2}{*}{$\begin{array}{c}\text { US } \\
\text { Estimated } \\
\text { Worker } \\
\text { Population }\end{array}$} & \multirow{2}{*}{$\begin{array}{c}\text { NHIS } \\
\text { sample } \\
\text { size }^{1}\end{array}$} & \multicolumn{3}{|c|}{ Yes } & \multicolumn{3}{|c|}{ No } \\
\hline & & & Number & Percent $^{2}$ & $\begin{array}{l}\text { Standard } \\
\text { error }\end{array}$ & Number & Percent $^{2}$ & $\begin{array}{c}\text { Standard } \\
\text { error }\end{array}$ \\
\hline $\begin{array}{l}\text { All subgroups } \\
\text { Gender }\end{array}$ & $8,947,375$ & 15,437 & 4,516 & 29.8 & 0.45 & 10,921 & 70.2 & 0.45 \\
\hline Male & $4,903,958$ & 7,622 & 2,085 & 28.4 & 0.59 & 5,537 & 71.6 & 0.59 \\
\hline $\begin{array}{l}\text { Female } \\
\text { Race }\end{array}$ & $4,043,417$ & 7,815 & 2,431 & 31.5 & 0.63 & 5,384 & 68.5 & 0.63 \\
\hline White & $7,884,204$ & 13,110 & 4,033 & 31.1 & 0.49 & 9,077 & 68.9 & 0.49 \\
\hline Black & 715,325 & 1,732 & 376 & 21.7 & 1.23 & 1,356 & 78.3 & 1.23 \\
\hline $\begin{array}{c}\text { Other } \\
\text { Ethnicity }\end{array}$ & 347,846 & 595 & 107 & 16.7 & 1.69 & 488 & 83.3 & 1.69 \\
\hline Non-Hispanic & $8,360,710$ & 13,982 & 4,300 & 30.9 & 0.47 & 9,682 & 69.1 & 0.47 \\
\hline $\begin{array}{l}\text { Hispanic } \\
\text { Age group }\end{array}$ & 586,665 & 1,455 & 216 & 13.9 & 1.13 & 1,239 & 86.1 & 1.13 \\
\hline 60-64 & $5,060,713$ & 8,296 & 1,516 & 18.9 & 0.51 & 6,780 & 81.1 & 0.51 \\
\hline $\begin{array}{l}\quad 65 \text { and older } \\
\text { Education }^{3}\end{array}$ & $3,886,662$ & 7,141 & 3,000 & 44.0 & 0.70 & 4,141 & 56.0 & 0.70 \\
\hline Less than HS & $1,385,505$ & 2,718 & 662 & 26.2 & 1.08 & 2,056 & 73.8 & 1.08 \\
\hline High school & $2,850,046$ & 4,865 & 1,402 & 29.1 & 0.78 & 3,463 & 70.9 & 0.78 \\
\hline $\begin{array}{l}\text { More than HS } \\
\text { Insurance }\end{array}$ & $4,651,458$ & 7,753 & 2,432 & 31.4 & 0.62 & 5,321 & 68.6 & 0.62 \\
\hline Insured & $8,391,603$ & 14,396 & 4,395 & 30.9 & 0.48 & 10,001 & 69.1 & 0.48 \\
\hline Uninsured & 544,635 & 1,018 & 119 & 12.4 & 1.19 & 899 & 87.6 & 1.19 \\
\hline
\end{tabular}

Source: Contract Report (March 2010). NORA Morbidity and Disability: The National Health Interview Survey (NHIS) $1997-2007$. Department of Epidemiology and Public Health, University of Miami School of Medicine

The estimates from this table are based on a question from the National Health Interview Survey that asked respondents "Have you ever had a pneumonia shot? This shot is usually given once or twice in a person's lifetime and is different from the flu shot. It is also called the pneumococcal vaccine."

1 Sample size from the National Health Interview Survey for the years 1997-2007

2 Percent (prevalence) estimated from the National Health Interview Survey for the years 1997-2007

${ }^{3}$ Response categories include (1) less than High School graduate, (2) High School graduate or GED, and (3) Some college or higher education. 
Table 56. Prevalence of never receiving a pneumococcal vaccination estimated for workers 60 years and older, Healthcare and Social Assistance sector, National Health Interview Survey, 1997-2007

\begin{tabular}{|c|c|c|c|c|c|c|c|c|}
\hline \multirow[b]{2}{*}{ Subgroup } & \multirow{2}{*}{$\begin{array}{c}\text { US } \\
\text { Estimated } \\
\text { Worker } \\
\text { Population }\end{array}$} & \multirow{2}{*}{$\begin{array}{c}\text { NHIS } \\
\text { sample } \\
\text { size }^{1}\end{array}$} & \multicolumn{3}{|c|}{ Yes } & \multicolumn{3}{|c|}{ No } \\
\hline & & & Number & Percent $^{2}$ & $\begin{array}{l}\text { Standard } \\
\text { error }\end{array}$ & Number & Percent $^{2}$ & $\begin{array}{l}\text { Standard } \\
\text { error }\end{array}$ \\
\hline $\begin{array}{l}\text { All subgroups } \\
\text { Gender }\end{array}$ & $1,288,932$ & 2,435 & 749 & 31.7 & 1.09 & 1,660 & 68.3 & 1.09 \\
\hline Male & 371,567 & 608 & 189 & 33.4 & 2.28 & 406 & 66.6 & 2.28 \\
\hline $\begin{array}{l}\text { Female } \\
\text { Race }\end{array}$ & 917,365 & 1,827 & 560 & 31.0 & 1.24 & 1,254 & 69.0 & 1.24 \\
\hline White & $1,052,433$ & 1,891 & 611 & 33.3 & 1.24 & 1,258 & 66.7 & 1.24 \\
\hline Black & 163,309 & 423 & 109 & 26.2 & 2.72 & 311 & 73.8 & 2.72 \\
\hline $\begin{array}{l}\text { Other } \\
\text { Ethnicity }\end{array}$ & 73,190 & 121 & 29 & 21.1 & 4.28 & 91 & 78.9 & 4.28 \\
\hline Non-Hispanic & $1,204,943$ & 2,199 & 705 & 32.8 & 1.15 & 1,469 & 67.2 & 1.15 \\
\hline $\begin{array}{l}\text { Hispanic } \\
\text { Age group }\end{array}$ & 83,989 & 236 & 44 & 15.8 & 2.71 & 191 & 84.2 & 2.71 \\
\hline $60-64$ & 717,754 & 1,273 & 257 & 21.6 & 1.31 & 1,005 & 78.4 & 1.31 \\
\hline $\begin{array}{l}\quad 65 \text { and older } \\
\text { Education }^{3}\end{array}$ & 571,178 & 1,162 & 492 & 44.5 & 1.67 & 655 & 55.5 & 1.67 \\
\hline Less than HS & 164,513 & 368 & 108 & 32.0 & 2.98 & 259 & 68.0 & 2.98 \\
\hline High school & 352,011 & 660 & 190 & 28.3 & 2.07 & 466 & 71.7 & 2.07 \\
\hline $\begin{array}{l}\text { More than HS } \\
\text { Insurance }\end{array}$ & 765,454 & 1,398 & 448 & 33.0 & 1.47 & 930 & 67.0 & 1.47 \\
\hline Insured & $1,220,842$ & 2,288 & 729 & 32.7 & 1.12 & 1,533 & 67.3 & 1.12 \\
\hline Uninsured & 67,118 & 145 & 20 & 15.2 & 3.52 & 125 & 84.8 & 3.52 \\
\hline
\end{tabular}

Source: Contract Report (March 2010). NORA Morbidity and Disability: The National Health Interview Survey (NHIS) $1997-2007$. Department of Epidemiology and Public Health, University of Miami School of Medicine

The estimates from this table are based on a question from the National Health Interview Survey that asked respondents "Have you ever had a pneumonia shot? This shot is usually given once or twice in a person's lifetime and is different from the flu shot. It is also called the pneumococcal vaccine."

1 Sample size from the National Health Interview Survey for the years 1997-2007

2 Percent (prevalence) estimated from the National Health Interview Survey for the years 1997-2007

${ }^{3}$ Response categories include (1) less than High School graduate, (2) High School graduate or GED, and (3) Some college or higher education. 


\section{References}

Behrens V, Seligman P, Cameron L, Mathias CG, Fine L [1994]. The prevalence of back pain, hand discomfort, and dermatitis in the US working population. Am J Public Health 84(11):1780-5.

Biddlecom AE, LeClere FB, Hardy AM, Hendershot GE [1992]. National study of knowledge of AIDS, testing patterns, and self-assessed risk among health care workers. J Acquir Immune Defic Syndr 5(11):1131-6.

Botman SL, Jack SS [1995]. Combining National Health Interview Survey Datasets: issues and approaches. Stat Med 14(5-7):669-77.

Brackbill R, Frazier T, Shilling S [1994a]. Smoking characteristics of US workers, 1978-1980. Am J Ind Med 13(1):5-41.

Brackbill RM, Cameron LL, Behrens V [1994b]. Prevalence of chronic diseases and impairments among US farmers, 1986-1990. Am J Epidemiol 139(11):1055-65.

Caban AJ, Lee DJ, Fleming LE, Gómez-Marin O, LeBlanc W, Pitman T [2005]. Obesity in US workers: The National Health Interview Survey, 1986 to 2002. Am J Public Health 295(9):1614-22.

Caban-Martinez AJ, Lee DJ, Fleming LE, Arheart KL, Leblanc WG, Chung-Bridges K, Christ S, Pitman T [2007a]. Dental care access and unmet dental care needs among U.S. workers: The National Health Interview Survey, 1997 to 2003. J Am Dent Assoc 138(2):227-30.

Caban-Martinez AJ, Lee DJ, Fleming LE, LeBlanc WG, Arheart KL, Chung-Bridges K, Christ SL, McCollister KE, Pitman T [2007b]. Leisure-time physical activity levels of the US workforce. Prev Med 44(5):432-6.

CDC [2000]. Measuring Healthy Days. Population Assessment of Health-Related Quality of Life. Atlanta, GA: Centers for Disease Control and Prevention. [http://www.cdc.gov/hrqol/pdfs/mhd.pdf]. Date accessed: October 17, 2011.

Christ SL, Lee DJ, Fleming LE, Leblanc WG, Arheart KL, Chung-Bridges K, Caban AJ, McCollister KE. [2007]. Employment and occupation effects on depressive symptoms in older americans: does working past age 65 protect against depression? J Gerontol B Psychol Sci Soc Sci 62(6):S399-403.

Cooper SP, Buffler PA, Lee ES, Cooper CJ [1993]. Health characteristics by longest held occupation and industry of employment: United States, 1980. Am J Ind Med 24(1):25-39.

Engstrom JL, Paterson SA, Doherty A, Trabulsi M, Speer KL [2003]. Accuracy of self-reported height and weight in women: an integrative review of the literature. J Midwifery Womens Health 48(5):338-45. 
Fleming LE, Gómez-Marin O, Zheng D, Ma F, Lee D [2003]. National Health Interview Survey mortality among US farmers and pesticide applicators. Am J Ind Med 43(2):227-33.

Fleming LE, LeBlanc W, Pitman P, Caban A, Gómez-Marín O, Lee D, Zheng D, Dulce J [2004]. Monograph: Occupation, Disability and Self Reported Health: The National Health Interview Survey 1986-1994. [http://www.umiamiorg.com/publications/monograph/thenationalhealthinterviewsurveymonograph.pdf]. Date accessed: October 17, 2011.

Fleming LE, Pitman P, LeBlanc W, Caban A, Gómez-Marín O, Lee D, Zheng D, Dulce J [2005]. Monograph: Occupation and Mortality: The National Health Interview Survey (NHIS) 1986-1994. [http://www. umiamiorg.com/publications/monograph/mortalitymonograph.pdf]. Date accessed: October 17, 2011.

Fleming LE, Pitman P, LeBlanc W, Lee D, Chung Bridges K, Caban Martinez A, Gómez-Marín O, Christ S, McCollister K, Arheart K, Ferraro K [2007a]. Monograph: Occupations and Health Disparities: The National Health Interview Survey 1997-2004. [http://www.umiamiorg.com/publications/monograph/ Health\%20Disparities\%20Monograph.pdf]. Date accessed: October 17, 2011.

Fleming LE, Lee DJ, Martinez AJ, Leblanc WG, McCollister KE, Bridges KC, Christ SL, Arheart KL, Pitman T [2007b]. The health behaviors of the older US worker. Am J Ind Med 50(6):427-37.

Gómez-Marin O, Fleming LE, Lee DJ, LeBlanc W, Zheng D, Ma F, Jané D, Pitman T, Caban A Jr. [2004]. Acute and chronic disability among U.S. farmers and pesticide applicators: the National Health Interview Survey (NHIS). J Agric Saf Health 10(4):275-85.

Gómez-Marin O, Fleming LE, Caban A, Leblanc WG, Lee DJ, Pitman T [2005]. Longest held job in US occupational groups: the National Health Interview Survey. J Occup Environ Med 47(1):79-90.

Guo H, Tanaka S, Halperin W, Cameron L [1999]. Back pain prevalence in US industry and estimates of lost workdays. Am J Public Health 89(7):1029-1035.

Hurwitz EL, Morgenstern H [1997]. Correlates of back problems and back-related disability in the United States. J Clin Epidemiol 50(6):669-81.

Kuczmarski MF, Kuczmarski RJ, Najjar M [2001]. Effects of age on validity of self-reported height, weight, and body mass index: findings from the Third National Health and Nutrition Examination Survey, 1988-1994. J Am Diet Assoc 101(1):28-34.

La Rosa JH [1988]. Women, work, and health: employment as a risk factor for coronary heart disease. Am J Obstet Gynecol 158(6 Pt 2):1597-602.

Lee DJ, Fleming LE, Gomez-Marin O, Leblanc W [2004]. Risk of hospitalization among firefighters: the national health interview survey, 1986-1994. Am J Public Health 294(11):1938-9. 
Lee DJ, Fleming LE, Gómez-Marín O, LeBlanc WG, Arheart KL, Caban AJ, Christ SL, Chung-Bridges K, Pitman T. [2006a]. Morbidity ranking of US workers employed in 206 occupations: The National Health Interview Survey (NHIS) 1986-1994. J Occup Environ Med 48(2):117-134.

Lee DJ, Fleming LE, Leblanc WG, Arheart KL, Chung-Bridges K, Christ SL, Caban AJ, Pitman T. [2006b]. Occupation and lung cancer mortality in a nationally representative U.S. Cohort: The National Health Interview Survey (NHIS). J Occup Environ Med 48(8):823-32.

Lee DJ, Fleming LE, Arheart KL, LeBlanc WG, Caban AJ, Chung-Bridges K, Christ SL, McCollister KE, Pitman T [2007a]. Smoking rate trends in U.S. occupational groups: the 1987 to 2004 National Health Interview Survey. J Occup Environ Med 49(1):75-81.

Lee DJ, Fleming LE, McCollister KE, Caban AJ, Arheart KL, LeBlanc WG, Chung-Bridges K, Christ SL, Dietz N, Clark JD 3rd. [2007b]. Health care provider smoking cessation advice among US worker groups. Tob Control 16(5):325-8.

McCollister KE, Arheart KL, Lee DJ, Fleming LE, Davilla EP, Christ SL, Caban-Martinez AJ, West J, Clark JE, Erard MJ [2010]. Declining Health Insurance Access Among US Hispanic Workers: Not all Jobs are Created Equal. Am J Ind Med 53(2)163-70.

NCHS [1989]. National Center for Health Statistics Vital and Health Statistics Report Series 2, No. 110. Design and estimation for the National Health Interview Survey, 1985-94. By Massey JT, Moore TF, Parsons VL, Tadros W. Hyattsville, MD: U.S. Department of Health and Human Services, Public Health Service, Centers for Disease Control and Prevention, National Center for Health Statistics. DHHS Publication No. (PHS) 89-1384. [http://www.cdc.gov/nchs/data/series/sr_02/sr02 110.pdf].

NCHS [1990]. National Center for Health Statistics Vital and Health Statistics Report Series 10, No. 175. Types of injuries by selected characteristics: United States, 1985-87. By Collins JG. Hyattsville, MD: U.S. Department of Health and Human Services, Public Health Service, Centers for Disease Control and Prevention, National Center for Health Statistics. DHHS Publication No. (PHS) 91-1503. [http://www. cdc.gov/nchs/data/series/sr_10/sr10 175.pdf].

NCHS [1993a]. National Center for Health Statistics. Industry and Occupation coding for Death Certificates 1993. NCHS instruction manual, Part 19. Hyattsville, MD: U.S. Department of Health and Human Services, Centers for Disease Control and Prevention, National Center for Health Statistics.

NCHS [1993b]. National Center for Health Statistics Vital and Health Statistics Report Series 10, No. 186. Health Conditions among the currently employed: United States, 1988. By Park, C. H., Wagener, D. K., Winn, D. M., Pierce, J. P. Hyattsville, MD: U.S. Department of Health and Human Services, Public Health Service, Centers for Disease Control and Prevention, National Center for Health Statistics. DHHS Publication No. (PHS) 93-1514. [http://www.cdc.gov/nchs/data/series/sr 10/sr10 186.pdf]. 
NCHS [2000]. National Center for Health Statistics Vital and Health Statistics Report Series 2, No. 130. Design and estimation for the National Health Interview Survey, 1995-2004. By Botman SL, Moore TF, Moriarty CL, Parsons VL. Hyattsville, MD: U.S. Department of Health and Human Services, Centers for Disease Control and Prevention, National Center for Health Statistics. DHHS Publication No. (PHS) 2000-1330. [http://www.cdc.gov/nchs/data/series/sr_02/sr02 130.pdf].

NCHS [2002a]. National Center for Health Statistics Vital and Health Statistics Report Series 10, No. 205. Summary health statistics for U.S. adults: National Health Interview Survey, 1997. By Blackwell DL, Collins JG, Coles R. Hyattsville, MD: U.S. Department of Health and Human Services, Centers for Disease Control and Prevention, National Center for Health Statistics. DHHS Publication No. (PHS) 2002-1533. [http://www.cdc.gov/nchs/data/series/sr_10/sr10_205.pdf].

NCHS [2002b]. National Center for Health Statistics Vital and Health Statistics Report Series 10, No. 209. Summary health statistics for U.S. adults: National Health Interview Survey, 1998. By Pleis JR, Coles R. Hyattsville, MD: U.S. Department of Health and Human Services, Centers for Disease Control and Prevention, National Center for Health Statistics. DHHS Publication No. (PHS) 2003-1537. [http://www.cdc.gov/nchs/data/series/sr_10/sr10_209.pdf].

NCHS [2003a]. National Center for Health Statistics Vital and Health Statistics Report Series 10, No. 212. Summary health statistics for U.S. adults: National Health Interview Survey, 1999. By Pleis JR, Coles R. Hyattsville, MD: U.S. Department of Health and Human Services, Centers for Disease Control and Prevention, National Center for Health Statistics. DHHS Publication No. (PHS) 2003-1540. [http:// www.cdc.gov/nchs/data/series/sr 10/sr10 212.pdf].

NCHS [2003b]. National Center for Health Statistics Vital and Health Statistics Report Series 10, No. 215. Summary health statistics for U.S. adults: National Health Interview Survey, 2000. By Pleis JR, Schiller JS, Benson V. Hyattsville, MD: U.S. Department of Health and Human Services, Centers for Disease Control and Prevention, National Center for Health Statistics. DHHS Publication No. (PHS) 2004-1543. [http://www.cdc.gov/nchs/data/series/sr 10/sr10_215.pdf].

NCHS [2004a]. National Center for Health Statistics Vital and Health Statistics Report Series 10, No. 218. Summary health statistics for U.S. adults: National Health Interview Survey, 2001. By Lucas JW, Schiller JS, Benson V. Hyattsville, MD: U.S. Department of Health and Human Services, Centers for Disease Control and Prevention, National Center for Health Statistics. DHHS Publication No. (PHS) 2004-1546. [http://www.cdc.gov/nchs/data/series/sr 10/sr10_218.pdf].

NCHS [2004b]. National Center for Health Statistics Vital and Health Statistics Report Series 10, No. 222. Summary health statistics for U.S. adults: National Health Interview Survey, 2002. By Lethbridge-Cejku M, Schiller JS, Bernadel L. Hyattsville, MD: U.S. Department of Health and Human Services, Centers for Disease Control and Prevention, National Center for Health Statistics. DHHS Publication No. (PHS) 2004-1550.

[http://www.cdc.gov/nchs/data/series/sr_10/sr10_222.pdf]. 
NCHS [2005]. National Center for Health Statistics Vital and Health Statistics Report Series 10, No. 225. Summary health statistics for U.S. adults: National Health Interview Survey, 2003.By Lethbridge-Cejku M, Vickerie J. Hyattsville, MD: U.S. Department of Health and Human Services, Centers for Disease Control and Prevention, National Center for Health Statistics. DHHS Publication No. (PHS) 2005-1553. [http://www.cdc.gov/nchs/data/series/sr_10/sr10_225.pdf].

NCHS [2006a]. National Center for Health Statistics Vital and Health Statistics Report Series 10, No. 228. Summary Health Statistics for U.S. Adults: National Health Interview Survey, 2004. By LethbridgeCejku M, Rose D, Vickerie J. Hyattsville, MD: U.S. Department of Health and Human Services, Centers for Disease Control and Prevention, National Center for Health Statistics. DHHS Publication No. (PHS) 2006-1556.

[http://www.cdc.gov/nchs/data/series/sr_10/sr10_228.pdf].

NCHS [2006b]. National Center for Health Statistics Vital and Health Statistics Report Series 10, No. 232. Summary Health Statistics for U.S. adults: National Health Interview Survey, 2005. By Pleis JR, Lethbridge-Cejku M. Hyattsville, MD: U.S. Department of Health and Human Services, Centers for Disease Control and Prevention, National Center for Health Statistics. DHHS Publication No. (PHS) 2008-1560. [http://www.cdc.gov/nchs/data/series/sr 10/sr10 232.pdf].

NCHS [2007]. National Center for Health Statistics Vital and Health Statistics Report Series 10, No. 235. Summary Health Statistics for U.S. adults: National Health Interview Survey, 2006. By Pleis JR, Lethbridge-Cejku M. Hyattsville, MD: U.S. Department of Health and Human Services, Centers for Disease Control and Prevention, National Center for Health Statistics. DHHS Publication No. (PHS) 2008-1563. [http://www.cdc.gov/nchs/data/series/sr 10/sr10 235.pdf].

NCHS [2008]. National Center for Health Statistics National Health Interview Survey (NHIS) Public Use Data Release. NHIS Survey Description. Variance Estimation and Other Analytic Issues, pp. 97-108. [ftp://ftp.cdc.gov/pub/Health_Statistics/NCHS/Dataset_Documentation/NHIS/2007/srvydesc.pdf]. Date accessed: October 17, 2011).

Nelson DE, Emont SL, Brackbill RM, Cameron LL, Peddicord J, Fiore MC [1994a]. Cigarette smoking prevalence by occupation in the United States. A comparison between 1978 to 1980 and 1987 to 1990 . J Occup Med 36(5):516-25.

Nelson DE, Giovino GA, Emont SL, Brackbill R, Cameron LL, Peddicord J, Mowery PD [1994b]. Trends in cigarette smoking among US physicians and nurses. JAMA 271(16):1273-5.

NIOSH [1980]. Industrial Characteristics of Persons Reporting Morbidity during the Health Interview Surveys Conducted in 1969-1974. By Kaminski R, Spirtas R. Cincinnati, OH. U.S. Department of Health and Human Services, Center for disease Control, National Institute for Occupational Safety and Health, DHHS (NIOSH) Publication No. 80-123.

Research Triangle Institute [2004]. Software for Survey Data Analysis (SUDAAN) Version 8.0.2. Research Triangle Park, NC: Research Triangle Institute. 
Soderholm SC [2006]. National Occupational Research Agenda. Cross-sector research in the second decade. Presented at the 2006 NORA Symposium. Washington, D.C.. April 2006. [http://www.cdc.gov/ niosh/nora/symp06/pdfs/cross06present.pdf]. Date accessed: October 17, 2011.

Spencer EA, Appleby PN, Davey GK, Key TJ [2002]. Validity of self-reported height and weight in 4808 EPIC-Oxford participants. Public Health Nutr 5(4):561-5.

Sterling TD, Weinkam JJ [1989]. Comparison of smoking-related risk factors among black and white males. Am J Ind Med 15(3):319-33.

Sterling T, Weinkam J [1990]. The confounding of occupation and smoking and its consequences. Soc Sci Med 30(4):457-67.

Tanaka S, Wild DK, Seligman PJ, Halperin WE, Behrens VJ, Putz-Anderson V [1995]. Prevalence and work-relatedness of self-reported carpal tunnel syndrome among U.S. workers: analysis of the Occupational Health Supplement data of 1988 National Health Interview Survey. Am J Ind Med 127(4):451-70.

Wagener DK, Winn DW [1991]. Injuries in working populations: black-white differences. Am J Public Health 81(11):1408-14.

Zwerling C, Whitten PS, Davis CS, Sprince NL [1997]. Occupational injuries among workers with disabilities: the National Health Interview Survey, 1985-1994. JAMA 278(24):2163-6.

Zwerling C, Whitten PS, Davis CS, Sprince NL [1998]. Occupational injuries among older workers with visual, auditory, and other impairments. A validation study. J Occup Environ Med 40(8):720-3.

Zwerling C, Whitten PS, Sprince NL, Davis CS, Wallace RB, Blanck P, Heeringa SG [2003]. Workplace accommodations for people with disabilities: National Health Interview Survey Disability Supplement, 1994-1995. J Occup Environ Med 45(5):517-25. 


\section{Appendices}

\begin{tabular}{|c|c|c|c|c|c|}
\hline Detai & Matrix of Morbi & ty and Disabili & $\begin{array}{l}\text { pendix } 1 . \\
\text { Questions fror } \\
2007\end{array}$ & e NHIS asked & sistently 1997- \\
\hline Variable & NHIS Question & $\begin{array}{l}\text { NHIS Possible } \\
\text { Responses }\end{array}$ & NHIS variable Name & Study Definition & Study Missing Data (N) \\
\hline & & & nographics & & \\
\hline Gender & Are you male or female? & Male, Female & SEX & Male, female & None \\
\hline Age & $\begin{array}{l}\text { How old are you? } \\
\text { (years) }\end{array}$ & Age in years & AGE & $\begin{array}{l}\text { Continuous, } \\
\text { Categorized: } \\
1=18-24 \text { years } \\
2=25-64 \\
3=65+\end{array}$ & None \\
\hline Race & $\begin{array}{l}\text { What races do you } \\
\text { consider yourself to be? }\end{array}$ & $\begin{array}{l}\text { NHIS recode variable: } \\
\text { white, black, other. } \\
\text { Other includes other } \\
\text { race than white or black } \\
\text { such as includes Indian } \\
\text { American, Alaska native, } \\
\text { native Hawaiian, other } \\
\text { Pacific Islander, Asian, } \\
\text { Indian, Chinese, Filipino, } \\
\text { other race, multiple race. }\end{array}$ & RACE & $\begin{array}{l}\text { 1=White } \\
\text { 2=Black } \\
\text { 3=All Other }\end{array}$ & None \\
\hline Ethnicity & $\begin{array}{l}\text { Do you consider yourself } \\
\text { to be Hispanic or Latino? } \\
\text { Hispanic includes: } \\
\text { Puerto Rican, Cuban, } \\
\text { Dominican, Mexican, } \\
\text { Central/South American, } \\
\text { other Latin American, } \\
\text { other Hispanic }\end{array}$ & Hispanic, non-Hispanic & HISPAN_I & $\begin{array}{l}\text { 1=Non-Hispanic } \\
\text { 2=Hispanic }\end{array}$ & None \\
\hline Insurance & $\begin{array}{l}\text { Are you covered by } \\
\text { health insurance or any } \\
\text { other health care plan? }\end{array}$ & Yes, No & $\begin{array}{l}\text { PHICOV(97- } \\
\text { 99),NOTCOV(00-07) }\end{array}$ & $\begin{array}{l}1=\text { Insured } \\
2=\text { Not insured }\end{array}$ & 429 \\
\hline Education & $\begin{array}{l}\text { What is the highest level } \\
\text { of education that you } \\
\text { have completed? }\end{array}$ & $\begin{array}{l}1^{\text {st }}, 2^{\text {nd }}, \text { third, } 4^{\text {th }}, \text { fifth, } \\
6^{\text {th }}, 7^{\text {th }}, 8^{\text {th }}, 9^{\text {th }}, 10^{\text {th }}, \\
11^{\text {th }}, 12^{\text {th }} \text { no diploma, } \\
\text { GED, high school } \\
\text { diploma, some college } \\
\text { (no degree), associate } \\
\text { degree, bachelors, } \\
\text { masters, doctorate } \\
\text { degree }\end{array}$ & EDUC & $\begin{array}{l}<12 \text { years; } 12 \text { years; } \\
>12 \text { years }\end{array}$ & 968 \\
\hline
\end{tabular}

\section{Health Status}

\begin{tabular}{|c|c|c|c|c|}
\hline $\begin{array}{l}\text { Health Last } \\
\text { Year }\end{array}$ & $\begin{array}{l}\text { Compared with } 12 \\
\text { MONTHS AGO, would } \\
\text { you say your health is } \\
\text { (better, worse, or about } \\
\text { the same)? }\end{array}$ & $\begin{array}{l}\text { 1) Better, 2) Worse, 3) } \\
\text { about the same }\end{array}$ & AHSTATYR & $\begin{array}{l}\text { 1) Better, 2) Worse, 3) } \\
\text { about the same }\end{array}$ \\
\hline $\begin{array}{l}\text { Self Rated } \\
\text { Health }\end{array}$ & $\begin{array}{l}\text { Would you say health } \\
\text { in general is excellent, } \\
\text { very good, good, fair, or } \\
\text { poor? }\end{array}$ & $\begin{array}{l}\text { 1) excellent, very good, } \\
\text { good } \\
\text { 2) fair or poor }\end{array}$ & HEALTH & $\begin{array}{l}0=\text { =xcellent, very good, } \\
\text { good } \\
1=\text { fair or poor }\end{array}$ \\
\hline
\end{tabular}




\begin{tabular}{|c|c|c|c|c|c|}
\hline \multicolumn{6}{|c|}{$\begin{array}{l}\text { Appendix } 1 . \\
\text { Detailed Matrix of Morbidity and Disability Questions from the NHIS asked consistently 1997- } \\
2007\end{array}$} \\
\hline Variable & NHIS Question & $\begin{array}{l}\text { NHIS Possible } \\
\text { Responses }\end{array}$ & NHIS variable Name & Study Definition & Study Missing Data (N) \\
\hline $\begin{array}{l}\text { Bed Day } \\
\text { (Cat) }\end{array}$ & $\begin{array}{l}\text { During the PAST } 12 \\
\text { MONTHS, that is, since } \\
\text { [12 month ref date], } \\
\text { ABOUT how many days } \\
\text { did illness or injury keep } \\
\text { you in bed for more than } \\
\text { half of the day? (Include } \\
\text { days while an overnight } \\
\text { patient in a hospital). }\end{array}$ & Number of times & BEDDAYR & $\begin{array}{l}\text { Continuous and } \\
\text { categorical: } \\
1=0 \text { days } \\
2=1 \text { day } \\
3=2+\text { days }\end{array}$ & 1506 \\
\hline $\begin{array}{l}\text { Lost Work } \\
\text { Day (CAT) }\end{array}$ & $\begin{array}{l}\text { During the PAST } 12 \\
\text { MONTHS, that is, since } \\
\text { [12 month ref date], } \\
\text { ABOUT how many days } \\
\text { did you miss work at a } \\
\text { job or business because } \\
\text { of illness or injury (do not } \\
\text { include maternity leave)? }\end{array}$ & Number of times & WKDAYR & $\begin{array}{l}\text { Continuous and as } \\
\text { categorical: } \\
1=0 \text { days } \\
2=1 \text { day } \\
3=2-5 \text { days } \\
4=6+\text { days }\end{array}$ & 1942 \\
\hline
\end{tabular}

$\begin{array}{ll}\text { Special } & \text { Do you now have any } \\ \text { Equipment } & \text { health problem that } \\ & \text { requires you to use } \\ & \text { special equipment, such } \\ & \text { as a cane, a wheelchair, } \\ & \text { a special bed, or a } \\ & \text { special telephone? }\end{array}$

$\begin{array}{ll}\begin{array}{ll}\text { Any } \\ \text { functional } \\ \text { Limitations }\end{array} & \begin{array}{l}\text { NHIS recode based } \\ \text { on all the 12 NHIS } \\ \text { questions on activity } \\ \text { limitations }\end{array} \\ \text { Hearing } & \begin{array}{l}\text { Which statement best } \\ \text { describes your hearing } \\ \text { Impairment }\end{array} \\ & \begin{array}{l}\text { (without a hearing aid): } \\ \text { good, a little trouble, a } \\ \text { lot of trouble, deaf? }\end{array}\end{array}$

Any functional limitation (e.g. did not answer "not all") versus not limited in any way

Good, a little trouble, a AHEARST lot of trouble, deaf

Visual Impairment

FIA1AR

Yes, No AVISION
Based on two questions:

- Do you have trouble seeing, even when wearing glasses or contact lenses? and

- Are you blind or unable to see at all?
SPECEQ

Yes if said limitation to any of 12 questions, No if otherwise

1=hearing impaired if a little or a lot of trouble hearing, or deaf.

$0=$ Not hearing impaired

$1=$ visual impaired if 98 answered yes to any of the two questions $0=$ not visually impaired
152

383

59 


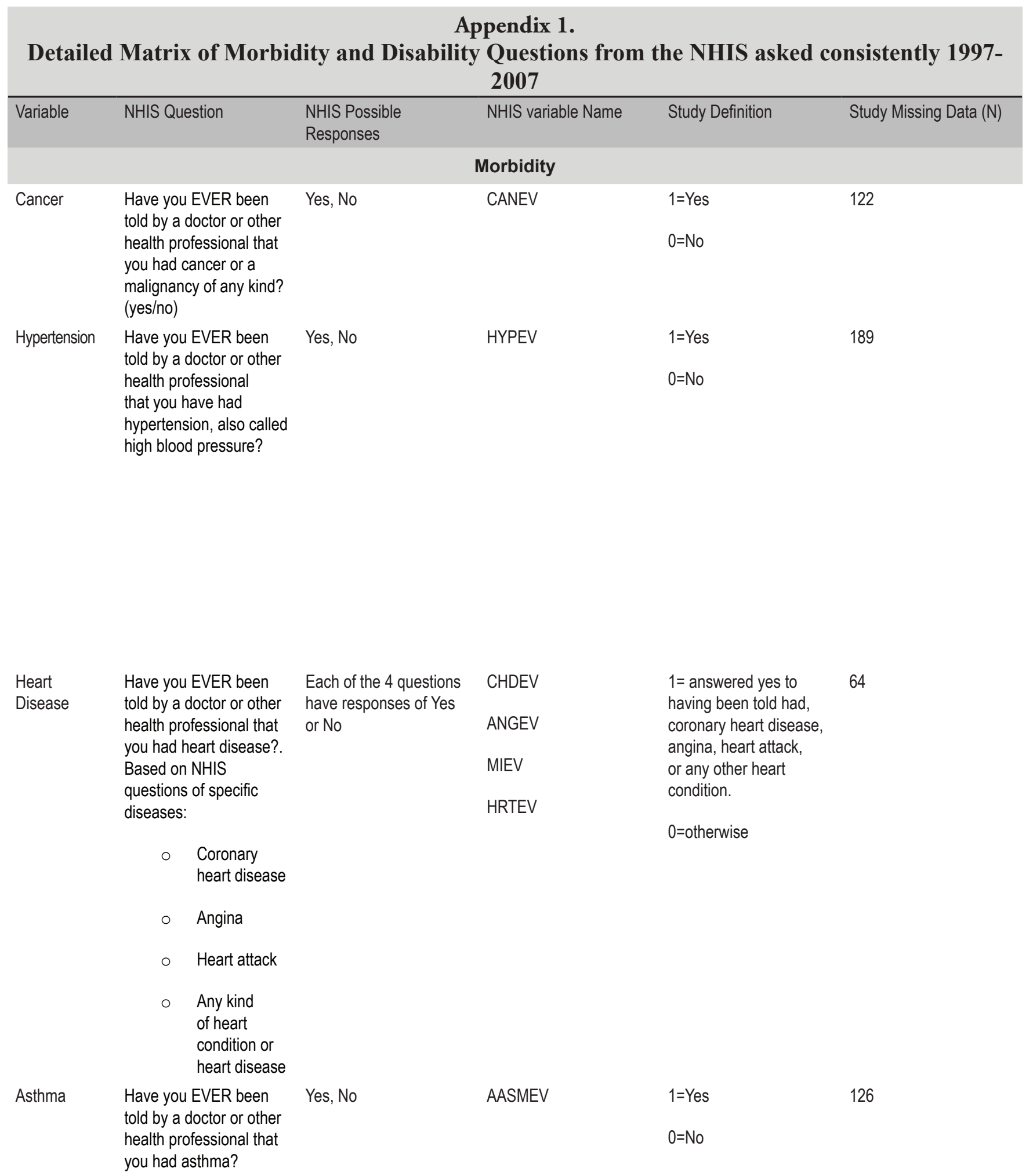




\section{Appendix 1.}

Detailed Matrix of Morbidity and Disability Questions from the NHIS asked consistently 19972007

\begin{tabular}{|c|c|c|c|c|c|}
\hline Variable & NHIS Question & $\begin{array}{l}\text { NHIS Possible } \\
\text { Responses }\end{array}$ & NHIS variable Name & Study Definition & Study Missing Data (N) \\
\hline $\begin{array}{l}\text { Severe } \\
\text { Psychological } \\
\text { Distress }\end{array}$ & $\begin{array}{l}\text { Is the individual } \\
\text { depressed? Based on } 6 \\
\text { NHIS questions: "During } \\
\text { the past } 30 \text { days how } \\
\text { often did you feel...? " } \\
\text { o so sad that } \\
\text { nothing could } \\
\text { cheer you } \\
\text { up? } \\
\quad \text { nervous? } \\
\quad \text { restless or } \\
\text { fidgety? } \\
\quad \text { hopeless? } \\
\text { that } \\
\text { everything } \\
\text { was an } \\
\text { effort? } \\
\text { worthless? }\end{array}$ & $\begin{array}{l}\text { For each of the } 6 \mathrm{NHIS} \\
\text { variables, responses } \\
\text { are: } 1=\text { All of the time, } \\
2=\text { most of the time, } \\
3=\text { some of the time, } 4=a \\
\text { little of the time, } 5=\text { none } \\
\text { of the time }\end{array}$ & $\begin{array}{l}\text { SAD } \\
\text { NERVOUS } \\
\text { RESTLESS } \\
\text { HOPELESS } \\
\text { EFFORT } \\
\text { WORTHHLS }\end{array}$ & $\begin{array}{l}\text { Score } 0-24 \text { based on } \\
\text { sum of the } 6 \text { depression } \\
\text { questions of number } \\
\text { of days with symptoms } \\
\text { (e.g. need cheering } \\
\text { up, nervous, restless/ } \\
\text { fidgety, hopeless, too } \\
\text { much effort, worthless, } \\
\text { in the past } 30 \text { days. } \\
\text { A cutoff of < } 13 \text { will be } \\
\text { used to define severe } \\
\text { psychological distress } \\
\text { (Pratt et al. 2007). }\end{array}$ & 1693 \\
\hline Diabetes & $\begin{array}{l}\text { Have you EVER been } \\
\text { told by a doctor or other } \\
\text { health professional that } \\
\text { you had diabetes or } \\
\text { sugar diabetes? }\end{array}$ & Yes, No & DIBEV & $\begin{array}{l}1=\text { Yes } \\
0=\mathrm{No}\end{array}$ & 1566 \\
\hline
\end{tabular}

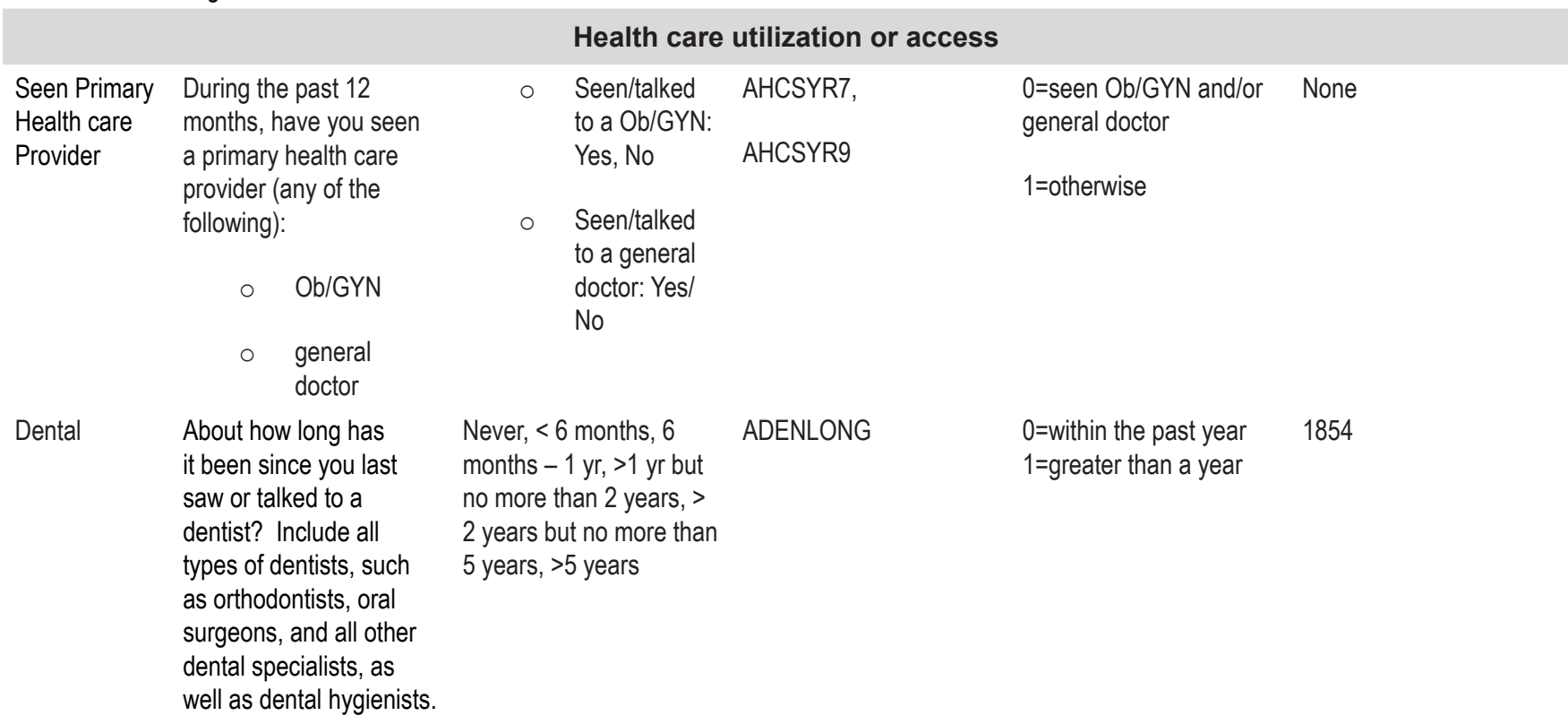




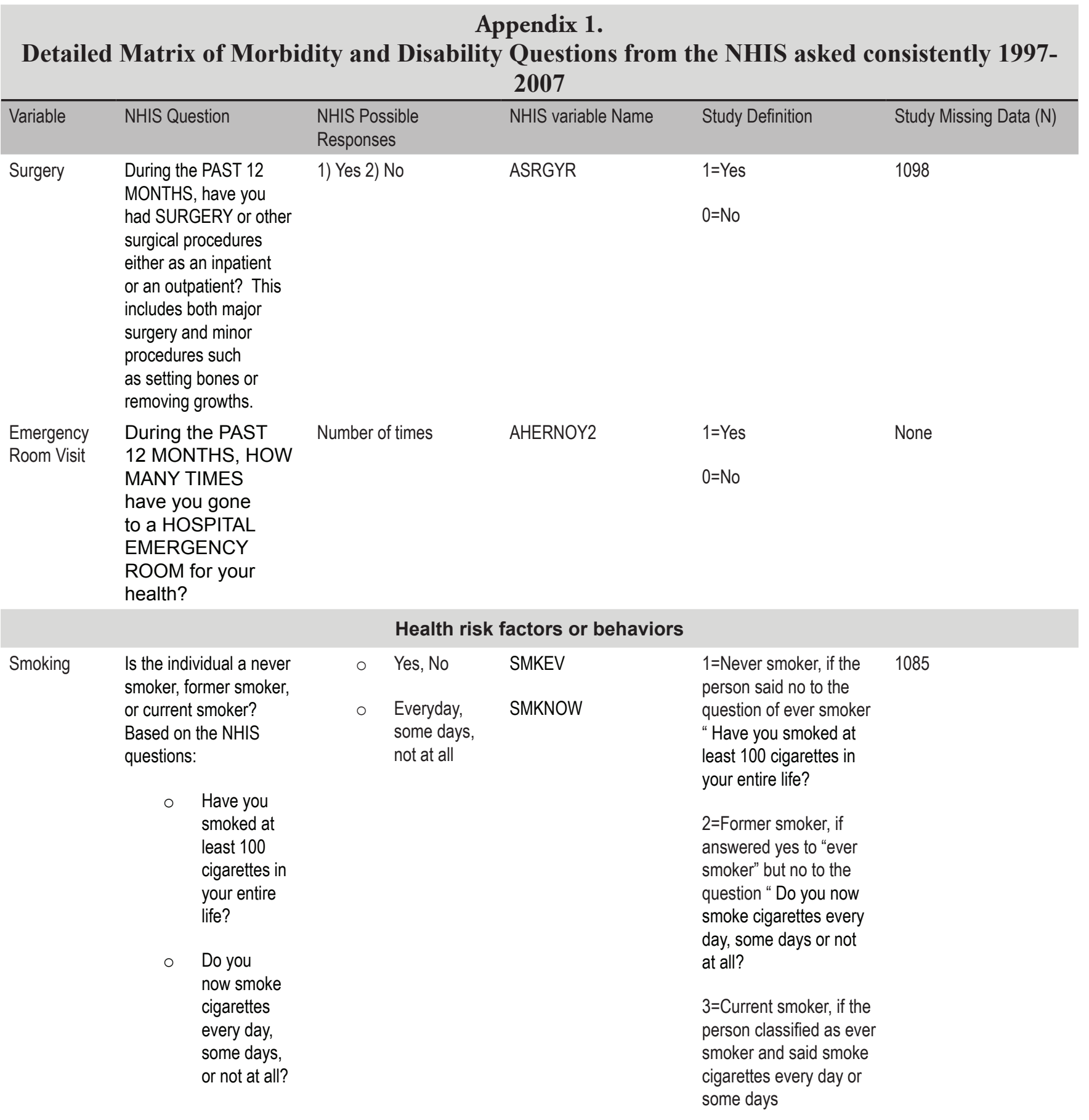




\section{Appendix 1.}

Detailed Matrix of Morbidity and Disability Questions from the NHIS asked consistently 19972007

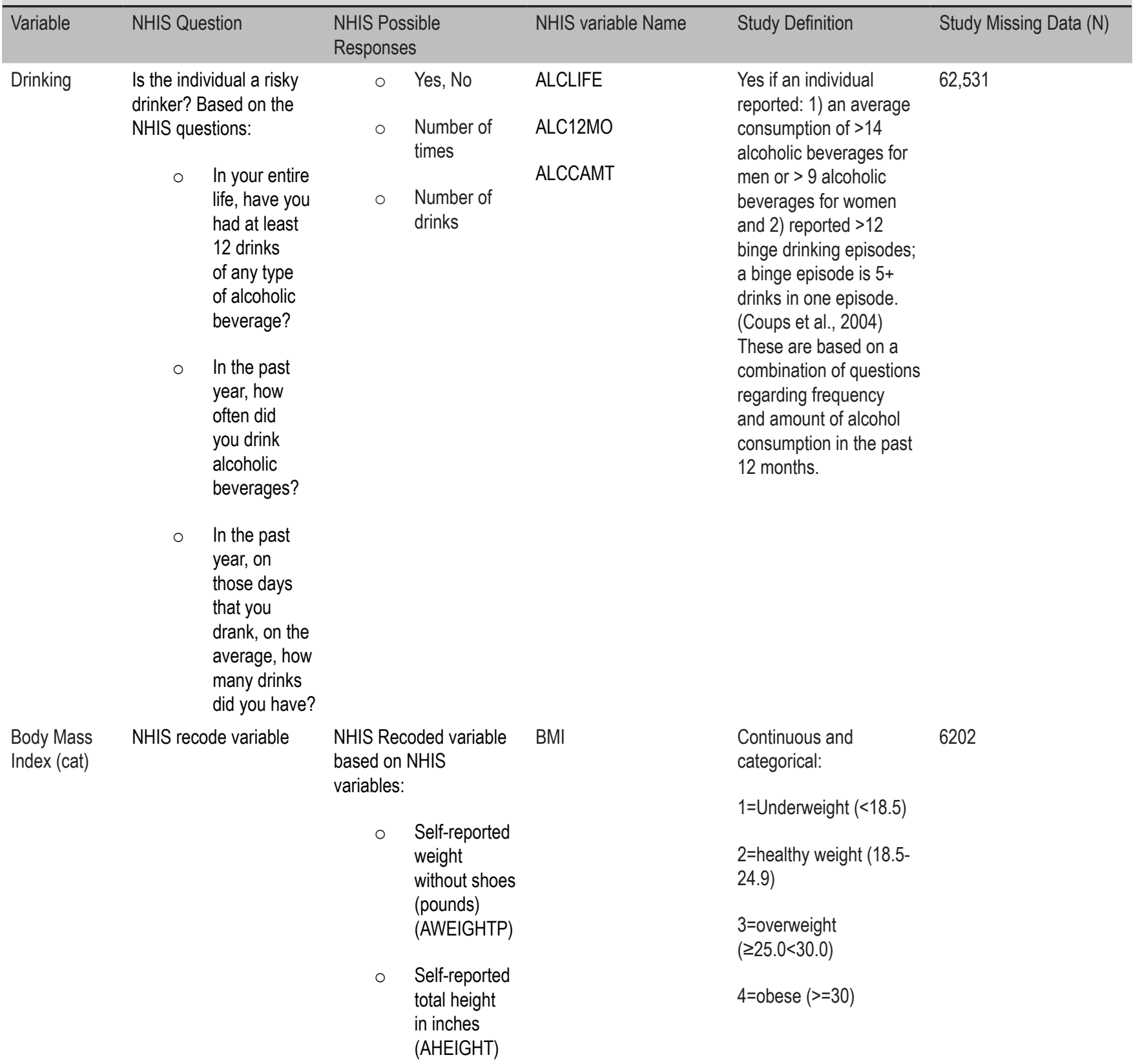




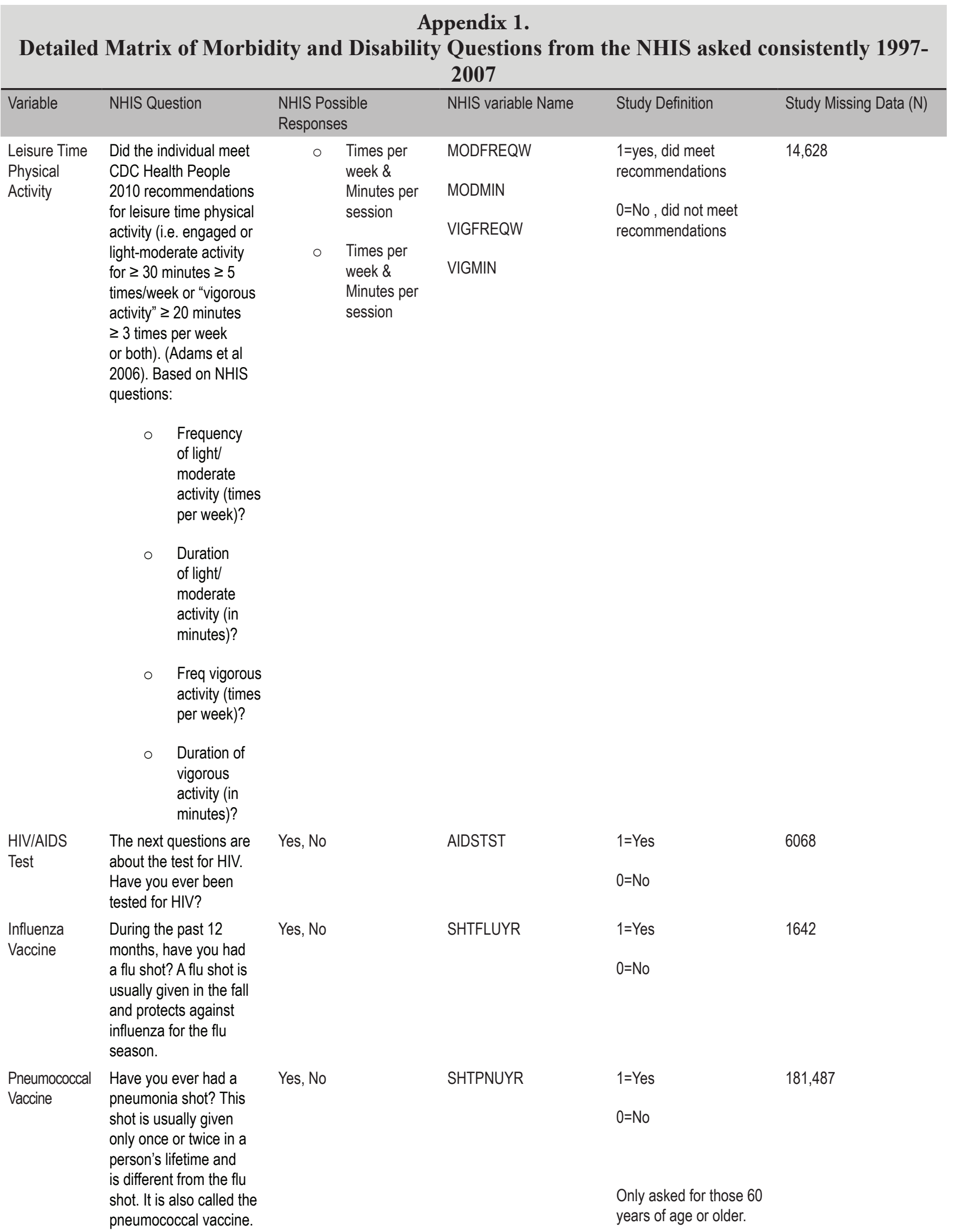


Appendix 2.

\section{Description of Conversion of 1986-2004 National Health Interview Survey (NHIS) Industries into NORA Sectors}

\section{NORA Sectors (http://www.cdc.gov/niosh/programs/)}

Sector 1 - Agriculture, Forestry, Fishing

Sector 2 - Construction

Sector 3 - Healthcare and Social Assistance

Sector 4 - Manufacturing

Sector 5 - Mining

Sector 6 - Services

Sector 7 - Transportation, Warehousing, Utilities

Sector 8 - Wholesale and Retail Trade

There is no issue in conversion from NHIS Industries into the NORA Sectors from 2005 NHIS onward since NHIS uses the NAICS Codes.

However, for 1986-2004 NHIS, the NHIS Industry codes do not translate directly into NORA Sectors, and a conversion is necessary (see attached figure which depicts the conversion process). The conversion from NHIS-recoded census industry codes into NORA Sector codes was accomplished using the NHIS Industry13 Recode to define Sectors $1,2,4,5,7$, and 8 as follows:

Sector 1 - Agriculture, Forestry and Fisheries (Industry 13 NHIS code 1)

Sector 5 - Mining (Industry 13 NHIS code 2)

Sector 2 - Construction (Industry13 NHIS code 3)

Sector 4 - Manufacturing (Industry13 NHIS code 4)

Sector 7 - Transport, Communication, Other Public Utilities (Industry13 NHIS code 5)

Sector 8 - Wholesale Trade (Industry13 NHIS code 6)

Sector 8 - Retail Trade (Industry13 NHIS code 7)

To define NORA Sectors 3 and 6, the following conversion was used:

Sector 6 - Finance, Insurance, Real Estate (Industry13 NHIS code 8)

Sector 6 - Business and Repair Services (Industry13 NHIS code 9)

Sector 6 - Personal Services (Industry13 NHIS code 10)

Sector 6 - Entertainment and recreation Services (Industry13 NHIS code 11)

Sector 6 - Professional/Related Services (Industry 13 NHIS code 12 [excluding Industry 41 NHIS codes 80,81 , and 84])

Sector 3 - Professional/Related Services (Industry 13 NHIS code 12 only for Industry 41 NHIS codes 80,81, and 84)

Sector 6 - Public Administration (Industry13 NHIS code 13)

Using the Industry41 NHIS code 84 to place workers in the Healthcare and Social Assistance sector has the undesirable result of also including Museums/art galleries/zoos, Labor Unions, and Membership organizations, n.e.c. industries. These people should be assigned to the Services Sector (NORA Sector 6). The 1986-1994 NHIS data sets provide a more detailed industry code that allows the identification of these groups (detail codes 872, 873, and 881 are designated by an asterisk (*)). For the 1986-1994 data sets, this would involve changing approximately 2,000 out of approximately 63,000 Healthcare Sector workers into Service Sector workers (3\%). Since this detailed industry code is publicly available in the NHIS data sets, this was done (see below). 
For the 1995-2004 NHIS data sets, this detailed industry information is not publicly available due to NCHS confidentiality concerns. The Services sector workers, who are inadvertently captured by this categorization of workers in Healthcare and Social Assistance sector, remain in the Healthcare and Social Assistance sector group for the estimates and analyses used for the 1997-2007 report.

\section{Specific explanation of detailed industry codes for 1986-1994 data:}

Three NHIS Census Industry Code (CIC) Recodes were used to define the Healthcare and Social Assistance NORA Sector 3: Industry41 code 80; Industry41 code 81; and Industry41 code 84. These subset of industries, are ordered below with corresponding NHIS Census Industrial Codes (CIC), Industry titles and 1987 Standardized Industry Codes (SIC) (SIC codes in parentheses).

\section{Industry41 CIC Industry Title (1987 Standardized Industry Codes)}

$\begin{array}{lll}\text { Recode 80 } & 831 & \text { Hospitals (806) } \\ \text { Recode 81 } & 812 & \text { Offices and clinics of physicians (801, 803) } \\ \text { Recode 81 } & 820 & \text { Offices and clinics of dentists (802) } \\ \text { Recode 81 } & 821 & \text { Offices and clinics of chiropractors (8041) } \\ \text { Recode 81 } & 822 & \text { Offices and clinics of optometrists (8042) } \\ \text { Recode 81 } & 830 & \text { Offices and clinics of health practitioners, n.e.c. (8043, 8049) } \\ \text { Recode 81 } & 832 & \text { Nursing and personal care facilities (805) } \\ \text { Recode 81 } & 840 & \text { Health services, n.e.c. (807, 808, 809) } \\ & & \\ \text { Recode 84 } & 861 & \text { Job training and vocational rehabilitation services (833) } \\ \text { Recode 84 } & 862 & \text { Child day care services (part 835) } \\ \text { Recode 84 } & 863 & \text { Family child care homes (part 835) } \\ \text { Recode 84 } & 870 & \text { Residential care facilities, without nursing (836) } \\ \text { Recode 84 } & 871 & \text { Social services, n.e.c. (832, 839) } \\ \text { Recode 84 } & 872 & \text { Museums, art galleries, and zoos (84)* } \\ \text { Recode 84 } & 873 & \text { Labor unions (863)* } \\ \text { Recode 84 } & 880 & \text { Religious organizations (866) } \\ \text { Recode 84 } & 881 & \text { Membership organizations, n.e.c. (861, 862, 864, 865, 869)* } \\ & (861): & \text { Business associations } \\ & (862): & \text { Professional membership organizations } \\ & (864): & \text { Civic, social, fraternal organizations } \\ & (865): & \text { Political associations } \\ \text { (869): } & \text { Membership organizations, n.e.c.; e.g., Travel motor clubs, Humane societies, } \\ & & \text { Farm business organizations, Athletic associations }\end{array}$

\section{References:}

The Relationship between the 1990 Census and Census 2000 Industry and Occupation Classification Systems, Technical Paper \#65. Prepared By Thomas S. Scopp

Under Special Contract with the U.S. Census Bureau, October 30, 2003

Map of 1987 SIC to 2002 NAICS:

http://www.census.gov/epcd/naics02/S87TON02.HTM 
Appendix 3: Conversion of 1986-2004 National Health Interview Survey (NHIS) Industries into NORA Sectors (flowchart)

\section{NORA SECTORS}

\begin{tabular}{|c|c|}
\hline $\begin{array}{c}\text { NoRA Sector 1 } \\
\text { Agriculture, Forestry } \\
\text { and Fishing }\end{array}$ & $\rightarrow \begin{array}{c}\begin{array}{c}\text { Agriculture, Forestry and } \\
\text { Fisheries }\end{array} \\
\text { (NHIS Industry13 code 1) }\end{array}$ \\
\hline
\end{tabular}

\section{NHIS INDUSTRY 13 AND INDUSTRY 41 CODES}

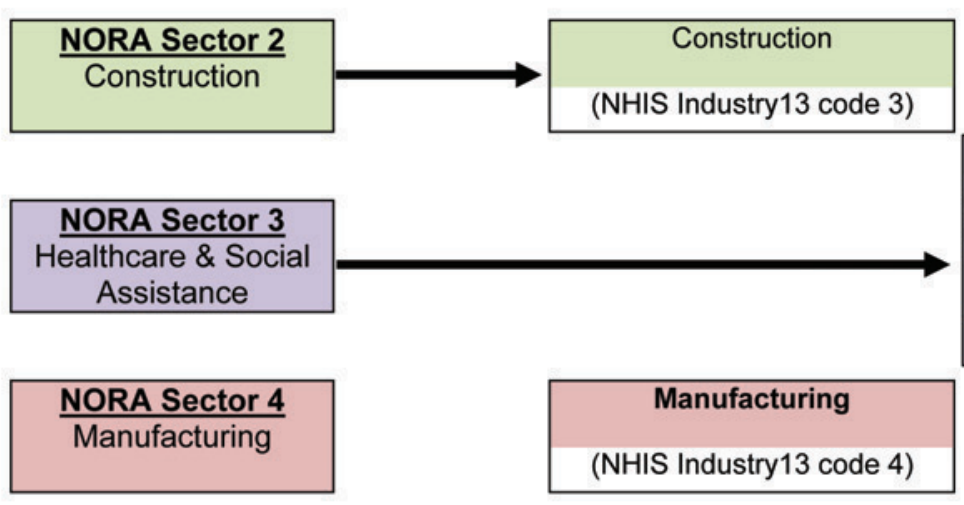

Healthcare \& Social Assistance NHIS Industry 13 code 12 subgroups Hospitals (NHIS Industry41 code 80 ) Health services, except hospitals

(NHIS Industry41 code 81) Social services / religious organizations (NHIS Industry41 code 84 )
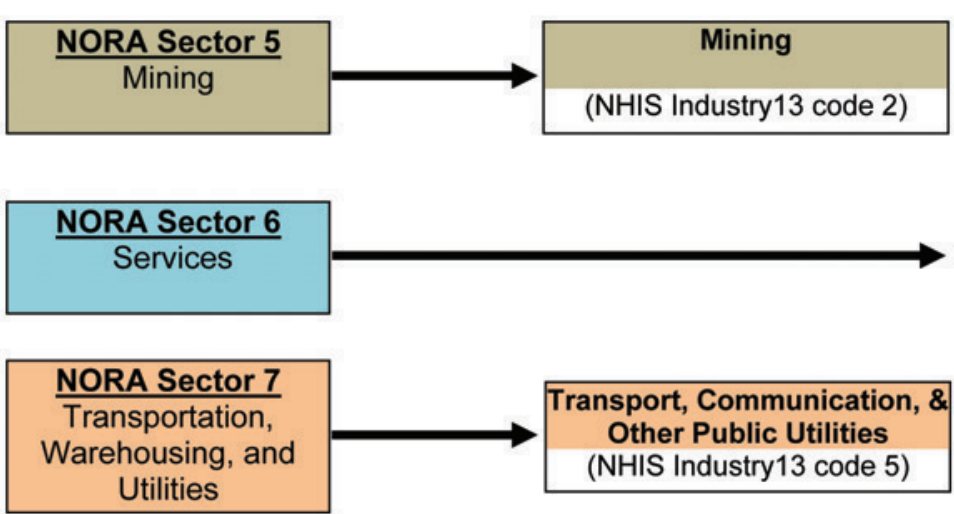

\begin{tabular}{|l|}
\hline \multicolumn{1}{|c|}{ Services* } \\
Finance, Insurance, Real Estate \\
(NHIS Industry13 code 8) \\
Business and Repair Services \\
(NHIS Industry13 code 9) \\
Personal Services (NHIS Industry13 code 10) \\
Entertainment and Recreation Services \\
(NHIS Industry13 code 11) \\
Professional / Related Services (NHIS \\
Industry13 code 12*) \\
Public Administration (NHIS Industry13 \\
code 13) \\
*See Appendix 2 pages 112-113. \\
\hline
\end{tabular}

\begin{tabular}{c|c|c|}
$\begin{array}{c}\text { NORA Sector } 8 \\
\text { Wholesale and } \\
\text { Retail Trade }\end{array}$ & $\begin{array}{c}\text { Wholesale Trade \& } \\
\text { Retail Trade } \\
\text { (NHIS Industry13 code } 6+7)\end{array}$ \\
\cline { 2 - 3 }
\end{tabular}




\section{Delivering on the Nation's promise: safety and health at work for all people through research and prevention}

To receive documents or other information about occupational safety and health topics, contact NIOSH

Telephone: 1-800-CDC-INFO (1-800-232-4636)

TTY: 1-888-232-6348

email: cdcinfo@cdc.gov

or visit the NIOSH website http://www.cdc.gov/niosh/

For a monthly update on news at NIOSH, subscribe to NIOSH eNews by visiting http://www.cdc.gov/niosh/eNews.

DHHS (NIOSH) Publication No. 2012-161

October 2012

DEPARTMENT OF HEALTH AND HUMAN SERVICES Centers for Disease Control and Prevention National Institute for Occupational Safety and Health
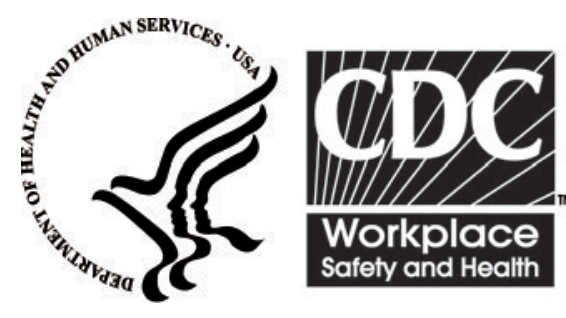